\title{
The causes and effect of temporal changes in magma generation processes in space and time along the Central Andes$$
\left(13^{\circ} \mathrm{S}-25^{\circ} \mathrm{S}\right)
$$

\author{
Dissertation \\ zur Erlangung des mathematisch-naturwissenschaftlichen Doktorgrades \\ "Doctor rerum naturalium" \\ der Georg-August-Universität Göttingen \\ im Promotionsprogramm Geowissenschaften / Geographie \\ der Georg-August University School of Science (GAUSS)
}

vorgelegt von

Rosanne Marjoleine Heistek

aus Nederland/Niederlande

Göttingen 2015 
Betreuungsausschuss:

Prof. Dr. Gerhard Wörner, Abteilung Geochemie, GZG

Prof. Dr. Andreas Pack, Abteilung Isotopengeologie, GZG

Referent:

Prof. Dr. Gerhard Wörner

Prof. Dr. Andreas Pack

Weitere Mitglieder der Prüfungskommission:

Prof. Dr. Sharon Webb

Prof. Dr. Hilmar von Eynatten

Prof. Dr. Jonas Kley

Dr. John Hora

Tag der mündlichen Prüfung: 25.06.2015 


\section{TABLE OF CONTENTS}

Acknowledgements....................................................................................................................................................1

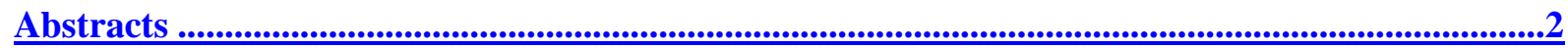

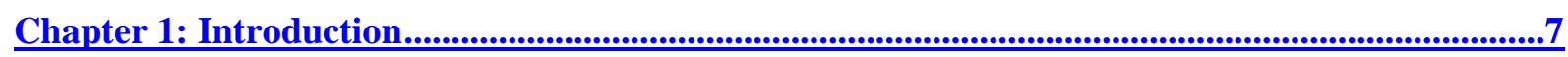

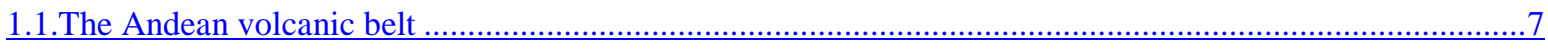

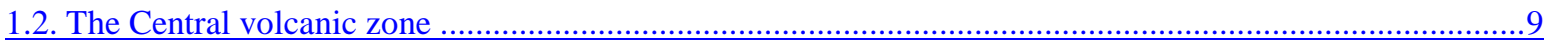

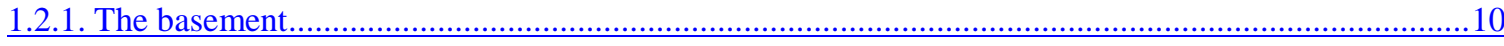

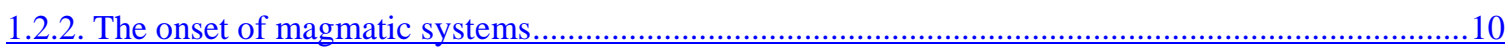

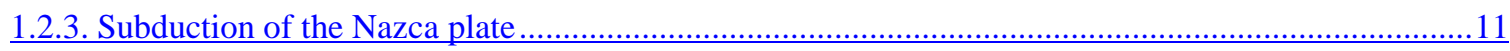

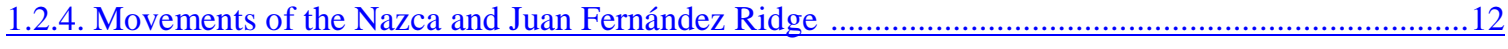

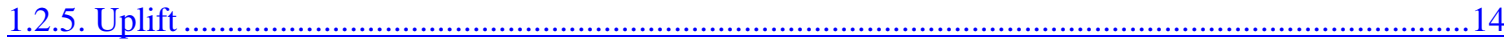

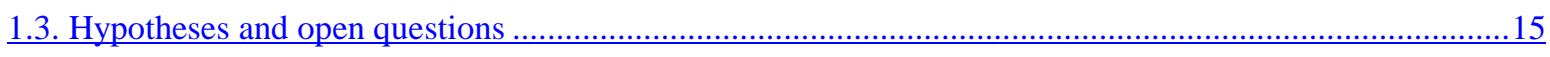

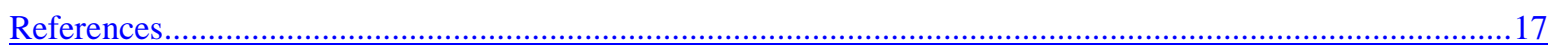

Chapter 2: Constraints on P-T conditions of crystallization and rates of magma formation before and after crustal thickening in the Central Andes .....................................................................24

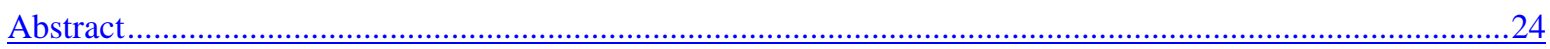

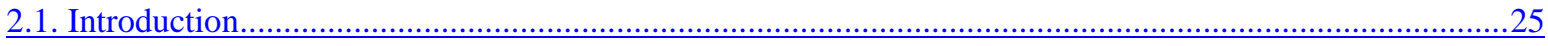

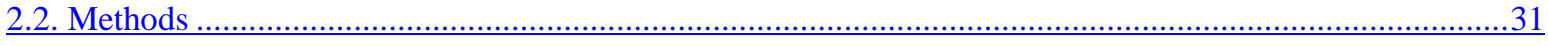

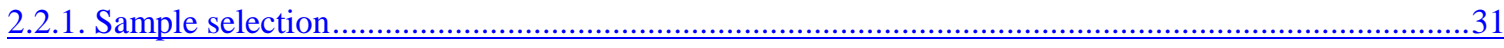

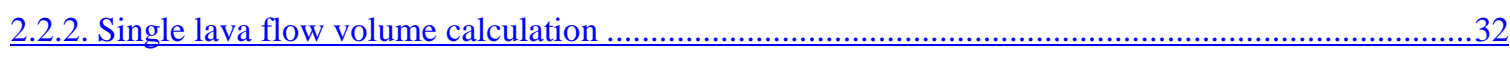

2.2.3. Major and trace elements ....................................................................................................... 33

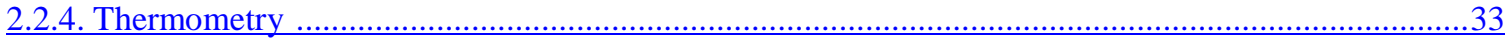

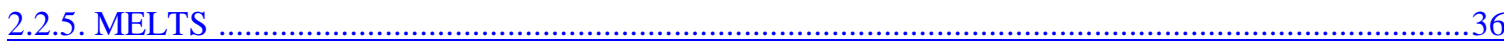

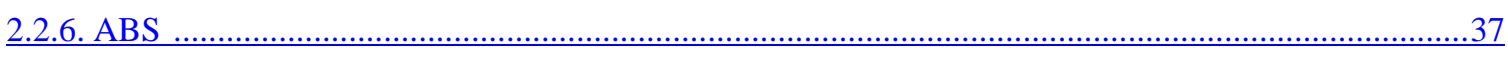

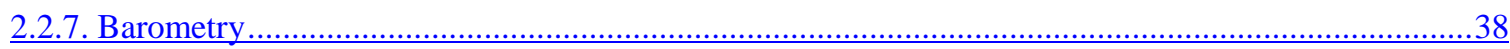

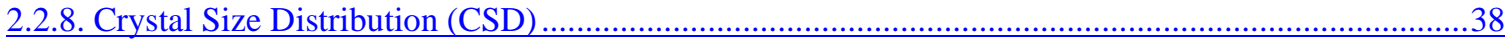

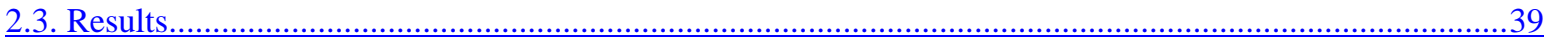

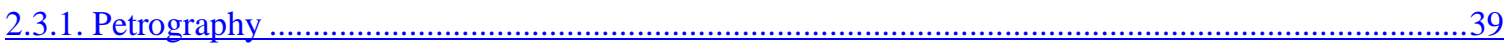

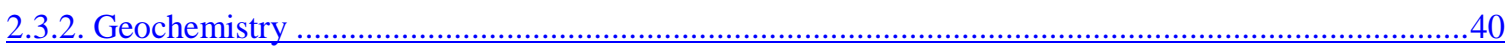

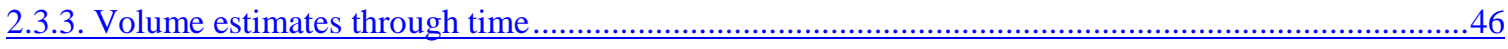

2.3.4. Conditions of the final stage of magmatic evolution ……….........................................................50

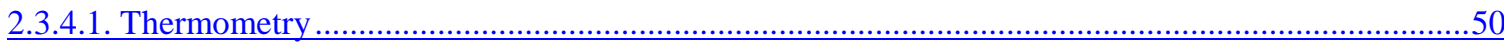

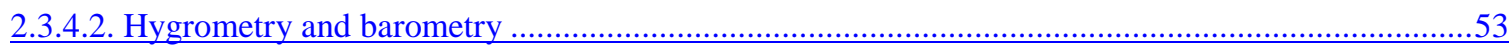

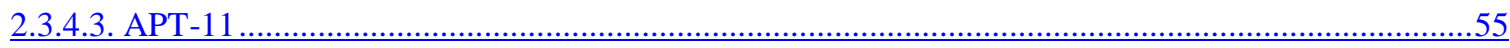

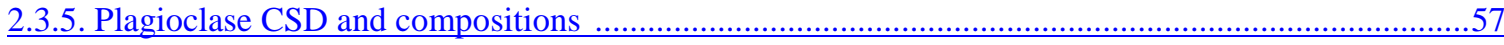

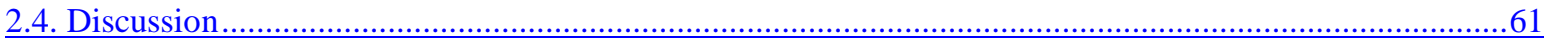

2.4.1 Formation of homogeneous intermediate magmas ...........................................................................61 


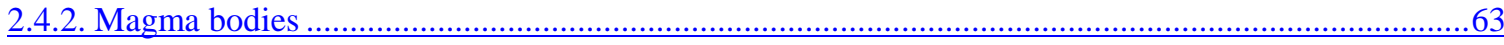

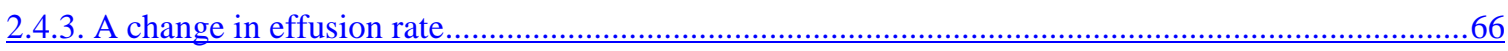

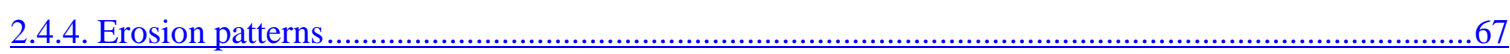

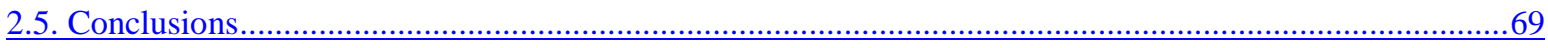

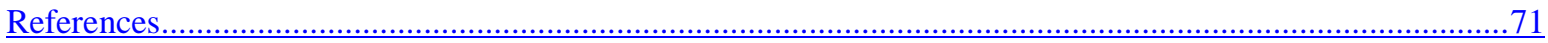

Chapter 3: Temporal changes in mantle wedge geometry and magma generation processes in the Central Andes: towards linking petrological data to thermomechanical models ...................................79

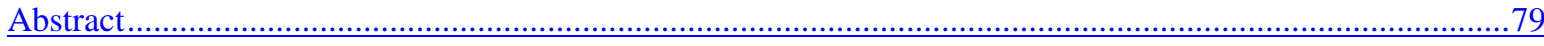

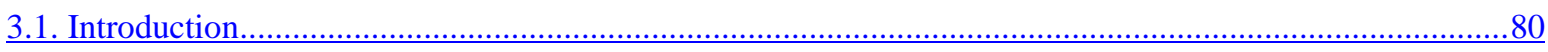

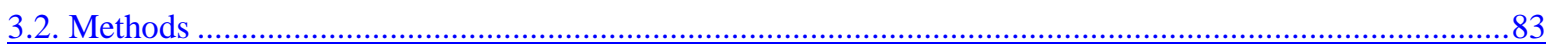

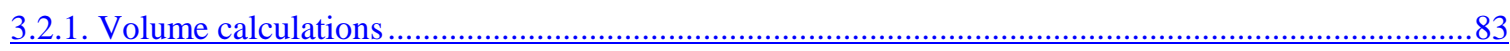

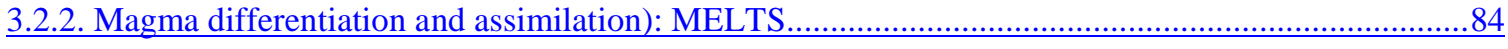

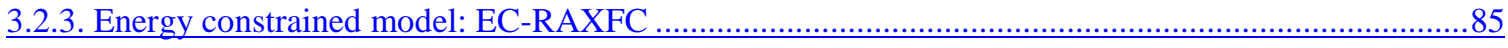

3.3. Areal extent, volumes and eruption rates: comparison of Miocene shields and Pliocene/Quaternary

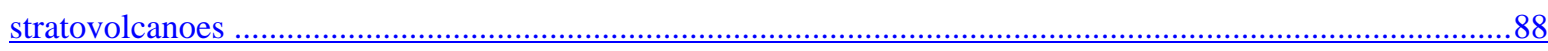

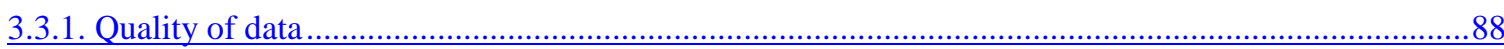

3.3.2. Volumes and eruption rates for Miocene lava shields and Pliocene/Quaternary stratovolcanoes trough

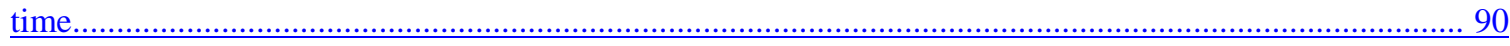

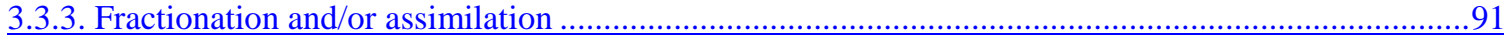

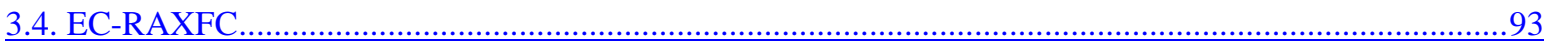

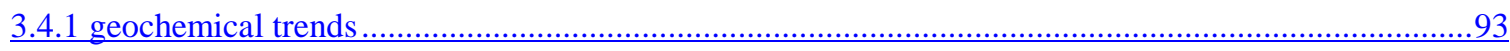

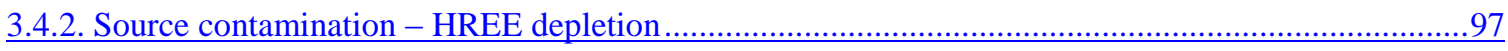

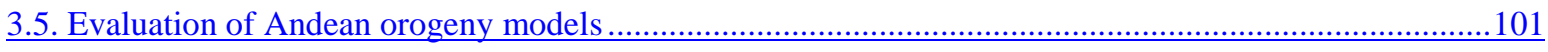

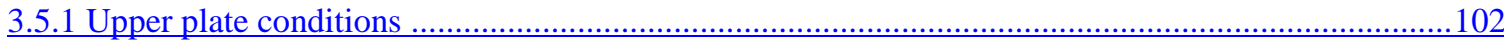

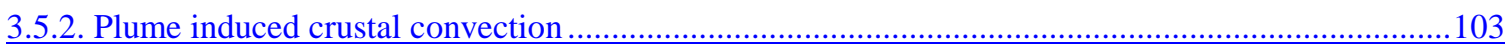

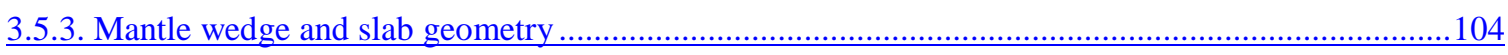

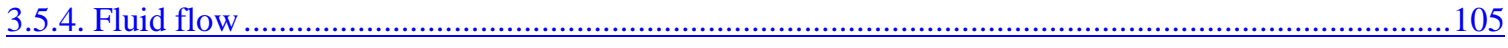

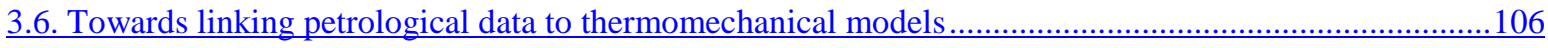

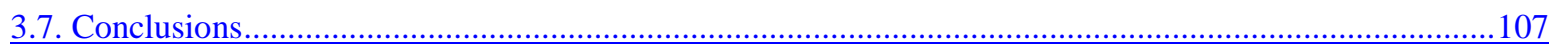

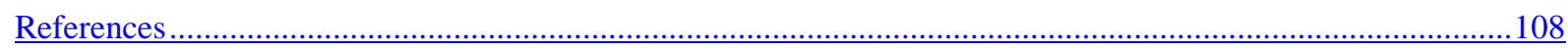

Chapter 4: Systematic compositional variation of magma compositions through time and space

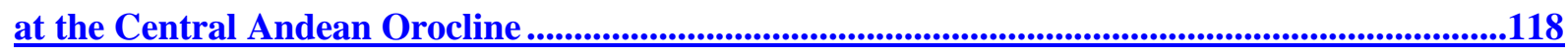

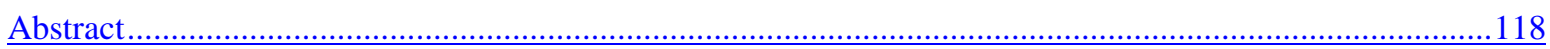

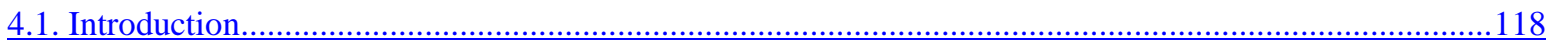

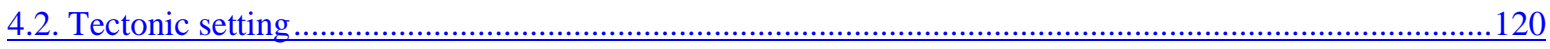

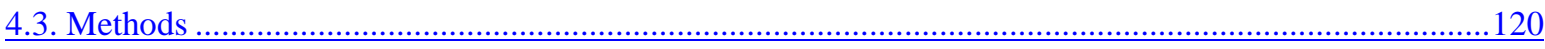

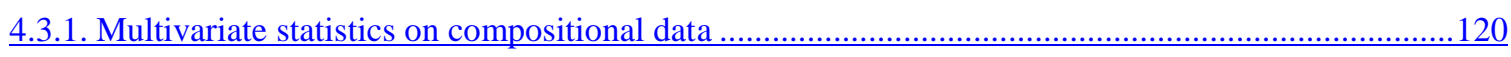

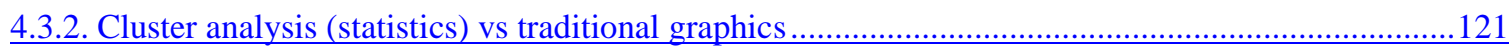

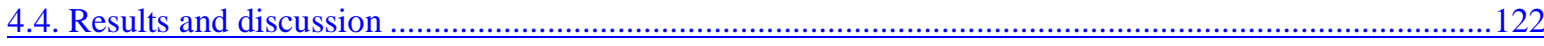




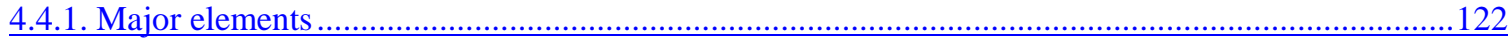

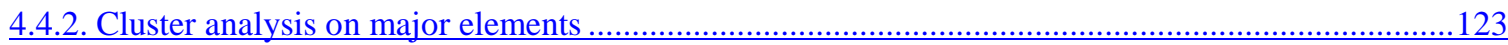

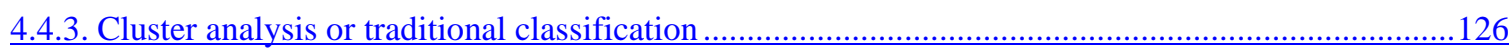

4.4.4. Major elements through time ………………….................................................................... 129

4.4.5. Trace elements signatures ……………………………................................................................. 131

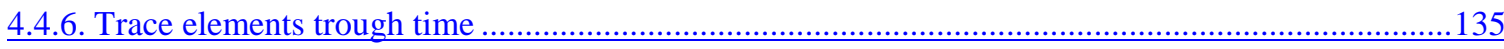

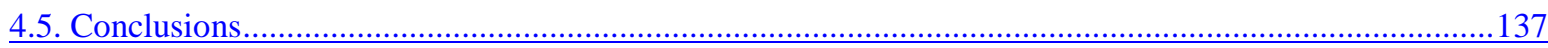

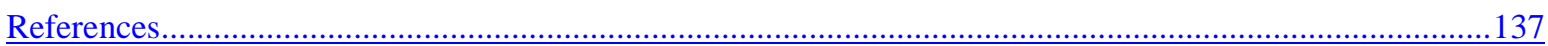

\section{APPENDIX}

EMPA

XRF

ICPMS

Petrographic photos 
Chapter 1 - Introduction

\section{Acknowledgements}

I would never have been able to finish my dissertation without the guidance of my committee members, help from friends, and support from my family and partner. I would like to express my deepest gratitude to my advisor, Prof. Gerhard Wörner, for his excellent guidance, caring, patience, and providing me with an excellent atmosphere for doing research. Even though my project had no funds, he always gave me full support, both financially and research wise to finish my $\mathrm{PhD}$. He let me experience the research of andesites in the field, lab, and practical issues beyond the textbooks and patiently corrected my writing and papers.

Furthermore I especially want to express my deepest gratitude to:

John Hora

Melanie Brandmeier

Andreas Kronz

Klaus Simon

Gerald Hartmann

Stefan Möller - McNett

For all your help, discussions and suggestions which had an immense impact on my thesis.

And of course special thanks to all my good friends and family

Mam and Dad

Dennis

Tim, Dafna, Mika and Floortje

Arjen

't Huisje

And of course many more

for believing in me! 


\begin{abstract}
This thesis investigates the timing and causes of the transition between two different magmatic regimes during the evolution of the Central Andean uplift. The first volcanic regime is represented by Miocene lava shields, which form low-angle, large-volume flows and are succeeded by considerable different more evolved, steep sided, low-volume stratovolcanoes.
\end{abstract}

Chapter 2: Constraints on P-T conditions of crystallization and rates of magma formation before and after crustal thickening in the Central Andes

Miocene volcanoes in the Central Andes typically overlie regionally extensive plateauforming ignimbrites (22 - $20 \mathrm{Ma}$ ) (Thouret et al., 2007; Noble and Farrar, 1979). These "early" lavas typically form low-angle, large-volume volcanic shields with long single lava flows with length up to $20 \mathrm{~km}$ (ranging from 0.03 to $9 \mathrm{~km}^{3}$ per lava flow with an average of $1.85 \mathrm{~km}^{3}$ ), and have compositions varying from andesites to dacites. These volcanic shields are succeeded by younger ("late") and more evolved steep-sided stratocones that presently characterize much of the CVZ active volcanic front. The young Pliocene-Quaternary stratovolcanoes are commonly characterized by amphibole phenocrysts.

In this chapter I present estimates for crystallization conditions through time and space in the Central Andes using multiple geothermo-baro-hygrometry methods on compositions ranging from 50 wt $\% \mathrm{SiO}_{2}$ to 65 wt $\% \mathrm{SiO}_{2}$. The analysis of a similar silica composition shows no significant differences in mineral compositions and therefore neither in crystallization temperatures in space and time. Furthermore there is no difference in crystallization pressure regimes through time suggesting the Andean uplift had no significant influence on the transition of Miocene lava shields to the Pliocene/Quaternary stratovolcanoes, even though the younger lavas had to pass through much thicker crust.

On the other hand, a clear decrease in HREE isotopes and yttrium with time shows a strong dependency on crustal thickening, leading to an increase in crystallization pressure through time. The main difference between the barometry and rare earth elements is the depth of crystallization, where the barometry indicates the final evolution of crystallization and REE's deep mantle wedge conditions. Therefore the final evolution of magma crystallization must become decoupled from the deep mantle and mantle wedge and lower crustal signatures. Thus complex mafic recharge, differentiation, assimilation, fractionation and magma mixing between two or multiple end members creates similar chemical andesites (which are the most common composition within the Central Andes) and therefore, they are only a final product of the magmatic evolution.

However, the high abundance of amphibole phenocrysts within the Pliocene/Quaternary samples shows low crystallization temperatures $\left(<950{ }^{\circ} \mathrm{C}\right)$ it seems therefore that the pathway of the young magmas is slower (has more time to cool down) compared to the Miocene magmas where amphibole are uncommon. The slower magmatic system during the Pliocene and Quaternary ensured lower magmatic minimum temperatures and by implication the higher viscosities and lower effusion 
rates created the small compound lava flows and leading to the clear distinction between the young stratovolcanoes and the Miocene lava shield, which is a fast system. Therefore, the rate of effusion and by implication, magma production and upper crustal stress regime rather than eruption temperature are the primary factors that influenced flow length and flow field type.

Chapter 3: Temporal changes in mantle wedge geometry and magma generation processes in the Central Andes: Towards linking petrological data to thermomechanical models

Volume and eruption rates are calculated for a compilation of 220 Miocene to Quaternary volcanic centers in the Central Andes. For the northern and central Altiplano the eruptive volumes are higher for Miocene volcanic centers (respectively 4681 in $15 \mathrm{Ma}$ and $5466 \mathrm{~km}^{3}$ in $11 \mathrm{Ma}$ ) compared to Pliocene/Quaternary stratovolcanoes (respectively 2110 and $2973 \mathrm{~km}^{3}$ both in $5 \mathrm{Ma}$ ), while for the southern Altiplano the eruption rates are higher for the younger stratovolcanoes (11470 in $10 \mathrm{Ma}$ compared to $12077 \mathrm{~km}^{3}$ in $5 \mathrm{Ma}$ ). Thus when calculating the eruption rates there is an overall intensification in eruption rate through time and space; for northern Altiplano 0.59 to $0.8 \mathrm{~km} / \mathrm{Ma} / \mathrm{km}$; central Altiplano 1.46 to 1.75 and for the southern Altiplano 1.45 to 3.06 and is linked to an already thickened crust in the south.

To evaluate chemical variations of lava through time and estimate the amount of mantle vs crustal melt thermodynamic models are fundamental tools, here I use a combination of MELTS for major elements and EC-RAxFC for trace elements and isotopes to advance the understanding of rates of magma formation and eruptions in the Central Andes. In general there is a poor agreement between the two models and analyzed samples; this is probably due to the unique place of the Central Andes where simple recharge, assimilation and mixing models are insufficient to explain chemical trends or make estimations about the amount of mantle or crustal melts.

To link petrological data to thermomechanical models, data of thermo- baro- and hygrometry, volumetric, eruption rates, intrusion : extrusion rates and even crustal contaminant are essential. Until now there is no thermomechanical model that combines petrology, fluid flow and upper crustal convection in a 3D model and link this to the evolution of the slab and mantle wedge geometry, tectonics and to towards the timing of crustal thickening. I believe based on previous thermomechanical modeling and petrological data that the time frame of especially crustal thickening is than much faster than previous assumed.

Chapter 4: Systematic compositional variation of magma compositions through time and space at the

\section{Central Andean Orocline}

In this chapter I analyzed temporal and compositional patterns of major elements and trace elements using multivariate statistics. The statistical technique, known as cluster analysis using kmeans, is used to correlate and integrate information about relations between major and trace elements. Here I try to test the hypothesis that not only do trace elements show a distinct signature 
through time in the Central Andes, but the major elements as well. Groups of major elements are formed based on their age and geochemical characteristics and are afterwards compared to the traditional classifications. Comparing these groups through time it becomes clear that major elements are not at all homogeneous for given silica content and through time distinct changes are shown. It thus seems that crustal thickening, by means of contamination, not only controls trace elements, but major elements as well. 


\section{Zusammenfassung}

Diese Arbeit beschäftigt sich mit dem zeitlichen Verlauf und den Gründen des Wechsels zwischen zwei magmatischen Regimen während der Hebung der Zentralen Anden. Das ältere vulkanische Regime wird durch miozäne Schildvulkane repräsentiert, die voluminöse Lavaströme hinterließen. Das zweite Regime besteht aus differenzierteren, steilen Stratovulkanen, mit einem weitaus geringeren Eruptionsvolumen.

2. Kapitel: P-T Bedingungen der Kristallisation und Magmenbildungsraten vor und nach der Krustenverdickung in den Zentralen Anden

In diesem Kapitel werden die Kristallisationsbedingungen in den Zentralen Anden präsentiert. Dafür werden multiple geothermo-baro-hygrometrische Methoden auf Proben mit $50 \mathrm{Gew} \% \mathrm{SiO}_{2}$ bis $65 \mathrm{Gew} . \% \mathrm{SiO}_{2}$ angewendet. Die hier analysierten Proben zeigen keinen zeit- oder raumabhängigen Unterschied in ihrer mineralogischen Zusammensetzung und deshalb auch keine Temperaturunterschiede. Weiterhin gibt es keine zeitabhängige Veränderung des Druckregimes, was dafür spricht, dass die Hebung der Anden keinen signifikanten Einfluss auf die Veränderung des vulkanischen Regimes hat. Andererseits zeigt die Abnahme der HREE und der Y-Isotope eine starke Abhängigkeit von der Krustenverdickung (bzw. der Druckzunahme). Aus diesem Grund muss die finale Entwicklung der Magmenkristallisation vom tiefen Mantel und dem Mantelkeil entkoppelt werden. Durch komplexe mafische Magmenzufuhr, Differentiation, Assimilation, Fraktionierung und Magmenmischung zwischen zwei oder mehreren Endkomponenten, entstehen chemisch sehr ähnliche Andesite. Diese repräsentieren also nur das Endprodukt einer komplexen magmatischen Entwicklung in den Zentralen Anden.

Allerdings lässt sich anhand der Themo- und Barometrie ein deutlicher Unterschied in der Dauer der beiden Magmensysteme erkennen. Das langsamere magmatische System während des Pliozäns und Quartärs führte zu niedrigeren magmatischen Temperaturen und sich daraus ergebenden höheren Viskositäten und geringeren Effusionraten. Diese führten zur Bildung der gering-volumigen Lavaströme. Das miozäne magmatische System hingegen ist schneller und führt zur Bildung der weitläufigeren Lavaschilde. Die Größe und Form der Lavaströme wird also primär durch die Effusionsrate und dementsprechend die Magmenproduktion, sowie dem Spannungsregime in der oberen Kruste beeinflusst und nicht durch die Temperatur.

3. Kapitel: Zeitliche Veränderungen in der Mantelkeilgeometrie und in Magmenbildungsprozessen in den Zentralen Anden. Verknüpfung von petrologischen Daten mit thermomechanischen Modellen

In diesem Kapitel wurden die Volumina und Eruptionsraten von 220 vulkanischen Zentren in den Zentralen Anden berechnet. Die Eruptionsvolumina im nördlichen und zentralen Altiplano sind während des Miozäns höher als während des Pliozäns/Quartär (4681 und $5466 \mathrm{~km}^{3}$ respektive). Im südlichen Altiplano hingegen sind die Eruptionsraten der jüngeren Stratovulkane deutlich höher 
(12077 km³ im Vergleich zu $11470 \mathrm{~km}^{3}$ für Miozäne vulkanische Zentren). Bei der Berechnung der Eruptionsraten fällt auf, dass diese mit der Zeit und von Norden nach Süden zunimmt und mit der Subduktion des Juan Fernandez Rücken zusammenhängt. Im nördlichen Altiplano steigen die Eruptionsraten von 0,59 bis 0,8, im zentralen Altiplano 1,46 bis 1,75 und im südlichen Altiplano 1,45 bis $3,06 \mathrm{~km}^{3} / \mathrm{Ma} / \mathrm{km}$.

Für die Bewertung chemischer Variationen der unterschiedlichen Lavaproben, sind thermodynamische Modelle fundamentale Werkzeuge. In dieser Arbeit wird eine Kombination aus MELTS für die Hauptelemente und EC-RAxFc für die Spurenelemente und Isotope benutzt, um Magmenbildungs- und Eruptionsraten in den Zentralen Anden besser zu verstehen. Im Allgemeinen gibt es keine guten Übereinstimmungen zwischen den beiden Modellen und den analysierten Proben. Dies ist möglicherweise auf die Einzigartigkeit der Zentralen Anden zurückzuführen, da hier einfache Zufuhr, Assimilations- und Magmenmischungsmodelle unzureichend sind, um die chemischen Entwicklung zu erklären.

Zur Verknüpfung von petrologischen Daten mit thermodynamischen Modellen, werden Informationen über Temperatur, Druck und Hygrometrie, sowie über Eruptionsraten, Intrusions- vs. Extrusionsraten und die krustale Verunreinigung benötigt. Bis jetzt gibt es kein thermomechanischen Modell, welches Petrologie, Fluidtransport und die Konvektion der oberen Kruste in einem 3D-Modell verbindet, um so die Geometrie der Platte und des Mantelkeils mit der Tektonik und der Krustenverdickung zu verknüpfen. Basierend auf früheren thermomechanischen Modellen und petrologischen Daten wird angenommen, dass der Zeitrahmen vor allem für die Krustenverdickung weitaus kleiner ist als bisher angenommen.

4. Kapitel: Systematische zeit-und raumabhängige Unterscheidung der chemischen Zusammensetzung von Lavaproben in der Orokline der Zentralen Anden

In diesem Kapitel werden Methoden der multivariaten Statistik eingesetzt, um die zeitliche Veränderung von Haupt- und Spurenelementzusammensetzung zu analysieren. Hierfür wurde die so genannte „Cluster Analyse“ benutzt, um Informationen über die Verbindung zwischen Haupt- und Spurenelemente zu korrelieren und zu integrieren. Ziel ist es die Hypothese zu testen, dass sich nicht nur die Spurenelementsignatur mit der Zeit verändert, sondern auch die Hauptelementsignatur. Weiterhin soll gezeigt werden, dass die Hauptelemente ein wichtiger Kontrollfaktor für die unterschiedlichen Spurenelementsignaturen sind.

Die Hauptelemente werden anhand ihrer geochemischen Eigenschaften gruppiert und mit üblichen Klassifikationen verglichen. Bezieht man alle Hauptelemente auf den $\mathrm{SiO}_{2}$-Gehalt und vergleicht dann die zuvor eingeteilten Gruppen über die Zeit, so wird deutlich, dass nicht alle Hauptelemente homogen verteilt sind, sondern teilweise deutliche zeitliche Veränderungen zeigen. Aufgrund dessen komme ich zu dem Schluss, dass die Krustenverdickung und die Verunreinigung nicht nur die Spurenelemente, sondern auch die Hauptelementzusammensetzung verändert. 


\section{Chapter 1}

\section{Introduction}

\subsection{The Andean volcanic belt}

The Andes are the world's longest continental mountain range. They consist of a continuous belt of highlands along the western continental margin of South America - about $8000 \mathrm{~km}$ long - and reach from Venezuela to the Tierra del Fuego. The range is between 200 and $700 \mathrm{~km}$ wide, at its widest between $18^{\circ} \mathrm{S}$ and $20^{\circ} \mathrm{S}$, where the average elevation is $4 \mathrm{~km}$ above sea level. The Altiplano is the world's second highest plateau, following the Tibetan Plateau. To the south, Aconcagua is the highest peak in the Andes at an elevation of $6,962 \mathrm{~m}$ above sea level.

The eastward subduction of the Nazca plate along the western edge of South America has produced an extensive orogeny with a continuous belt of igneous products that developed over at least the previous $26 \mathrm{Ma}$ (Pardo-Casas and Molnar, 1987; Isacks, 1988; Coira et al., 1982). The link between trench collision of aseismic ridges and flat slab segments plays an important role in the volcanic activity. After a phase of flat subduction and no magmatism the volcanic arc has been linked to the steepening of the subducting slab and to influx of hot asthenosphere into the mantle wedge (Isacks, 1988; Wörner et al., 1994; Kay et al., 1999; James and Sacks (1999).

At present the active volcanic arc is divided into three zones separated by inactive gaps.

- The northern volcanic zone (NVZ) in Colombia and Ecuador between latitudes $5^{\circ}$ and $2^{\circ} \mathrm{S}$ is a result of Mesozoic and Cenozoic collision of oceanic terranes, prior to the present Andean type setting (Bosch and Rodriguez, 1992)

- The central volcanic zone (CVZ) largely in south Peru and northern Chile, $16^{\circ}$ to $27^{\circ} \mathrm{S}$ has a long history of subduction and volcanic arc activity (Sérbrier and Soler, 1991; Isacks 1988; Allmendinger, 1997)

- And the southern volcanic zone (SVZ) largely in southern Chile, $33^{\circ}$ to $55^{\circ} \mathrm{S}$ recording the closing of a back arc oceanic basin (Ramos and Kay, 1992; Gorring et al., 1997)

All three active zones correspond to relative steep dipping segments of subducting slabs, whereas the inactive areas correspond to segments with much shallower dips $\left(10\right.$ to $\left.15^{\circ}\right)$ and relate to the segments of Bucaramanga (north of $5{ }^{\circ} \mathrm{N}$ ), Peruvian 3 to $15{ }^{\circ} \mathrm{S}$ and the Pampean flat slab segment (27 
to $33^{\circ} \mathrm{S}$ ). In all flat segments the subducting plate descends with a maximum dip of $30^{\circ}$ from the trench to a depth of approximately $100-120 \mathrm{~km}$ and then flattens beneath the overriding lithosphere for several hundred kilometers before descending into the upper mantle lithosphere (Martinod et al., 2010; Espurt et al., 2008).

Around $17-18^{\circ} \mathrm{S}$ the Andes bends, here the angle of convergence between the subducting Nazca plate and the South American plate changes from nearly perpendicular in the south to a somewhat oblique in the north (Beck et al.,1993; Oncken et al., 2006). The link between trench collision of aseismic ridges and flat slab segments play an important role in the volcanic activity. The zones of low dip angle correspond roughly to places where thicker and less dense oceanic crust is being subducted. The extra thickness is attributed to the Nazca ridge and the Chile rise. In zones of low subduction dip the mantle wedge above the slab is much thinner, leaving only the shallow lithospheric mantle in the western portion with the lower asthenospheric component to the eastern portion (Barazangi and Isacks, 1979). This lack of asthenosphere is the reason for the diminished volcanic activity and thus slab dip must play an important role in controlling whether or not magmatism occurs.

The type and thickness of crust that comprises the continental plate differ among the three volcanically active zones of the Andes. The Northern Volcanic Zone is underlain by mafic oceanic crust that was accreted in the Late Cretaceous and Cenozoic (Gansser, 1973; Alemán and Ramos, 2000; Jaillard et al., 2000). There, the crust is on the order of 30 to $45 \mathrm{~km}$ thick. Whereas in contrast to the NVZ, both the Central and Southern Andes are built on Paleozoic or older ensialic crust (Mpodzis and Ramos, 1990; Ramos, 2000; Jaillard et al., 2000; Hervé et al., 2000), these two volcanic zones are characterized by differences in their (1) pre-Andean basement ages, (2) Late Oligocene to Recent geologic evolution, (3) crustal thickness (thickest in the CVZ and variably thick in the SVZ), and (4) overall crustal composition (Lucassen et al., 2001; Tassara and Yáñez, 2003). 


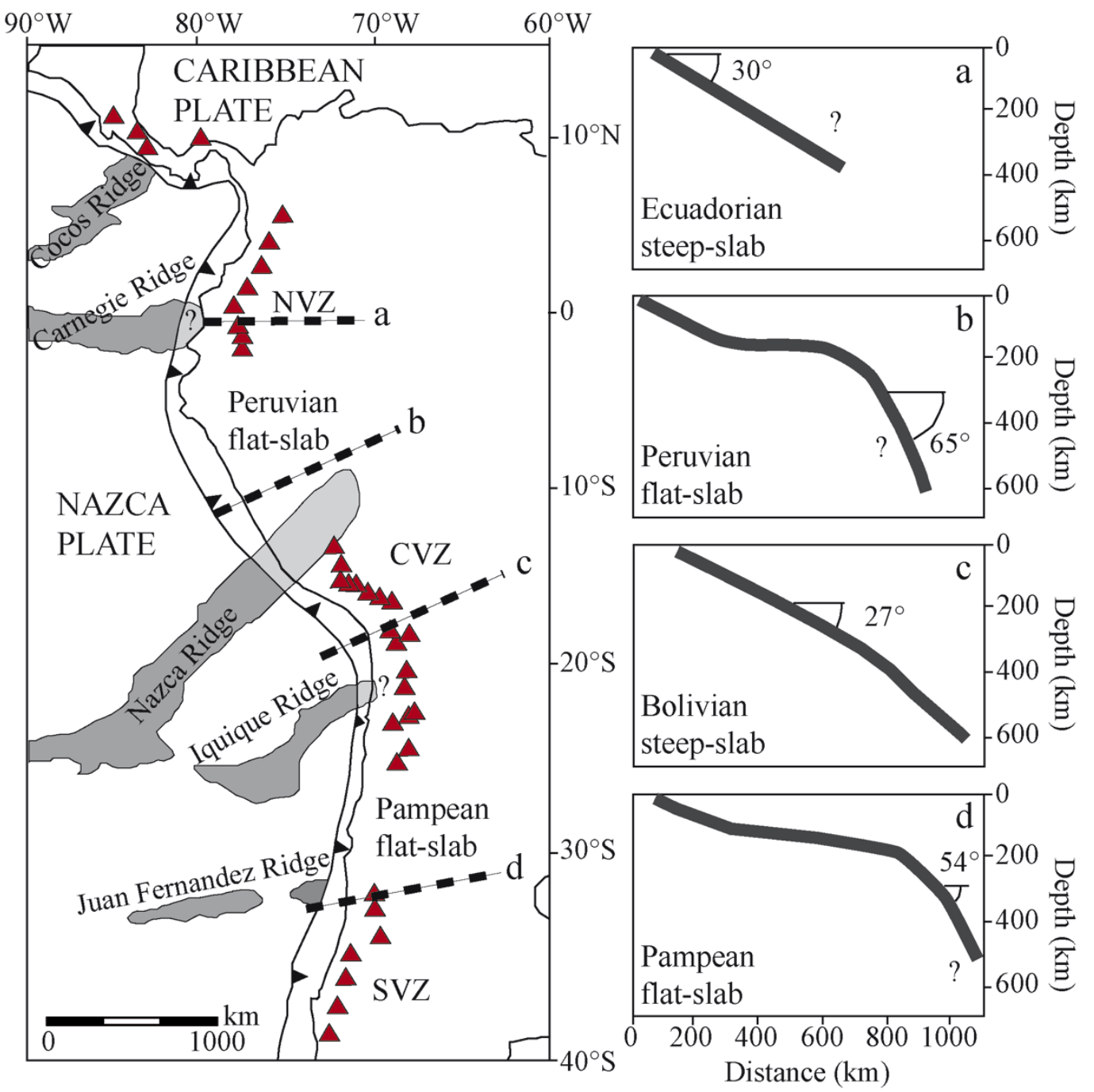

Fig.1. Plate-Tectonic settings of the Andes. The estimated subducted lengths topographic anomalies underneath the South American plate are shown in light grey areas. Red triangles mark active andesitic volcanism (Gutscher et al., 2006b). The profiles of the Nazca slab beneath the South American plate from earthquake epicenters showing the changes in slab dips in a N-S transect. (modified from Espurt et al., 2008).

\subsection{The Central Volcanic Zone (CVZ)}

The Central Volcanic Zone forms the western boundary of the Altiplano in southern Peru and northern Chile. The CVZ is underlain by continental crust up ot $70 \mathrm{~km}$ thick, a rusult of crustal thickening that began approximately $25 \mathrm{Ma}$ ago (Isacks, 1988). Within this zone of steep subduction, $\left(16^{\circ} \mathrm{S}\right.$ to $\left.24^{\circ} \mathrm{S}\right)$, there exist 44 major and 18 minor active volcanic centers (Stern, 2004). Slab dips are more shallow on either side of the CVZ. To the north, the slab dip abruptly changes between $13^{\circ}$ and $16^{\circ} \mathrm{S}$ in southern Peru-Bolivia. South of $24^{\circ} \mathrm{S}$, a smooth transition exists between $24^{\circ}$ and $27^{\circ} \mathrm{S}$ in northern Argentina (Allmendinger et al., 1997). 


\subsubsection{The basement}

Paleoproterozoic (2.0 - $1.8 \mathrm{Ga})$ metamorphic and igneous rocks of the Arequipa terrane in the northern central Andes are the oldest basement underneath the Andean arc. The current Pacific margin of South America is widely considered to be an assemblage of allochthonous or parautochthonous terranes that accreted to Gondwana during the Late Proterozoic and/or during the Early to MidPaleozoic (Ramos, 1988, 1995; Unrug, 1996; Astini et al., 1995). Metamorphic rocks with possible Paloeproterozoic protolith ages have been found in the southern central Andes at Cerro Uyarani on the Bolivian Altiplano, and in exposed basement at Belen, Chile. (Wörner et al., 2000a). Rocks with younger Grenvillian ages (1.3-1.0 Ga) protolith ages also are found at choja in northern Chile (Loewy et al., 2004).

A tectonic scenario is that terrane exchange ensued between the South American (Gondwana) and North American (Laurentia) cratons succeeding Grenvillian collision which molded the hypothetical supercontinent Rodinia (Wasteneys et al., 1995; Tosdal, 1996; Dalziel, 1997). Consequently separation was preceded by a second collision between Laurentia and Gondwana during the MidOrdovician Famatinian orogeny in the Andes and the Taconian orogeny in the Appalachians (Dalziel et al., 1994). An adjustment of the previous model places a small ocean between Laurentia and South America with arcs on or in front of the respective margins in the Early Ordovician. In Mid-Ordovician followed a probable collision of a continental platform derived from Laurentia including the Argentine Precordillera (Dalziel, 1997). In the Andes outcrops of metamorphic rocks are scarce but present the mountain chains from the Chilean Coast to their eastern slope. In north Chile continuous outcrops do not exist (Damm et al., 1990, 1994).

\subsubsection{The onset of magmatic systems}

The Mesozoic to Cenozoic arc is composed of a volcanic-clastic sequence that overlies a Proterozoic -Early Paleozoic complex of high-grade metamorphic rocks and granites. The oldest plutonic sequences are of Early Paleozoic (Miškovič et al., 2009; Chew et al., 2007; Miškovič and Schaltegger, 2009) and Carboniferous age and can be regarded as the evolution of the Proto-Andean margin on the edge of the Amazonas Craton (Chew at al., 2008 and references therein). The current magmatic system developed since the lower Jurassic due to the subduction of the Farallon-Nazca plate. During the Lower Jurassic ( 190 Ma), volcanism of the Precordillera shifted $200 \mathrm{~km}$ westward into the region of the present Coastal Cordillera and formed the Jurassic to Cretaceous arc system. The large volumes of Jurassic igneous rocks in the Coastal Cordillera are mantle derived (Rogers and Hawkesworth, 1989; Pichowiak et al., 1990; Lucassen and Thirlwall, 1998).

In the western Cordillera, Early Cretaceous plutons of the Coastal Batholith intruded folded Jurassic to Early Cretaceous volcanic-clastics, suggesting phase shortening in the Early Cretaceous (Jaillard and Soler, 1996; Soler and Bonhomme, 1990). The volcanic products consist out of thick beds of pillow lavas, sheet lavas and tuffs with a basaltic to intermediate composition occur. 
According to geochemical data it has been proposed that the volcanics characterize mantle-derived magmas that conceivably formed in a back arc setting (Atherton et al., 1985). The Coastal Batholith of Peru extends over $1680 \mathrm{~km}$ along the coast.

During the Late Cretaceous to Early Tertiary the eastward migration of the volcanic front took place (Ramos and Aleman, 2000). Volcanism increased again during this period and decreases during the Oligocene. Although volcanic activity decreases in the Oligocene intrusive activity is widespread and important during the Late Eocene and Oligocene (48-28 Ma). This period of waning volcanism coincides with a period of highly oblique convergence of the Nazca plate (Ramos and Aleman, 2000.

Previous to $26 \mathrm{Ma}$, a period of at least $5 \mathrm{My}$ of magmatic dormancy alongside the Peruvian margin occurred (Soler and Bonhomme; Soler, 1990). Except in the eastern Cordillera and the Altiplano of southern Peru are some extrusive and intrusive products (Sérbrier and Soler, 1991). Calcalkaline magmatic activity began again approximately at $26 \mathrm{Ma}$ all along the western Cordillera and has sustained to the present.

\subsubsection{Subduction of the Nazca plate}

During the Oligocene the East Pacific rise reached the North American subduction zone being progressively subducted underneath the continental lithosphere (e.g. Hamilton, 1987; Crowell, 1987). This event appears to be the onset of major plate boundary reorganization in the Pacific basin, like the Late Oligocene breakup of the Farallon plate into the Nazca and Cocos plates (e.g. Herron and Heirtzler, 1967; Mammerickx and Klitgord, 1982). Coeval events in the southeast Pacific were the intensification in spreading rate, the change in spreading direction on the Pacific Farallon (Nazca) ridge (Mayes et al., 1990, Tebbens et al., 1997) and near $40^{\circ}$ clockwise rotation of the Chile ridge axis (Tebbens and Cande, 1997).

Early Cenozoic magmatism and deformation in the Central Andes were largely focused in the present fore-arc region, even though evidence of uplifted zones in the back-arc region has been reported (Kennan et al., 1995). The abrupt change of plate convergence kinematics during Late Oligocene is coeval with a widespread eastward shift and broadening of the locus of main tectonic activity, and onset of the formation of the modern Central Andes.

A possibly strong acceleration of convergence during the Late Oligocene contributed to the mountain building in the Central Andean. The diminution of convergence rate since Late Miocene time approximately correlates with the last deformational phase in the orogeny and was characterized by the progressive end of internal deformation in the Altiplano-Puna region, acceleration of plateau uplift, and eastward jump of deformation to the Subandean and Sierras Pampeanas regions (Benjamin et al., 1987; Roeder, 1988; Isacks, 1988; Gubbels et al., 1993; Kley et al., 1997). 


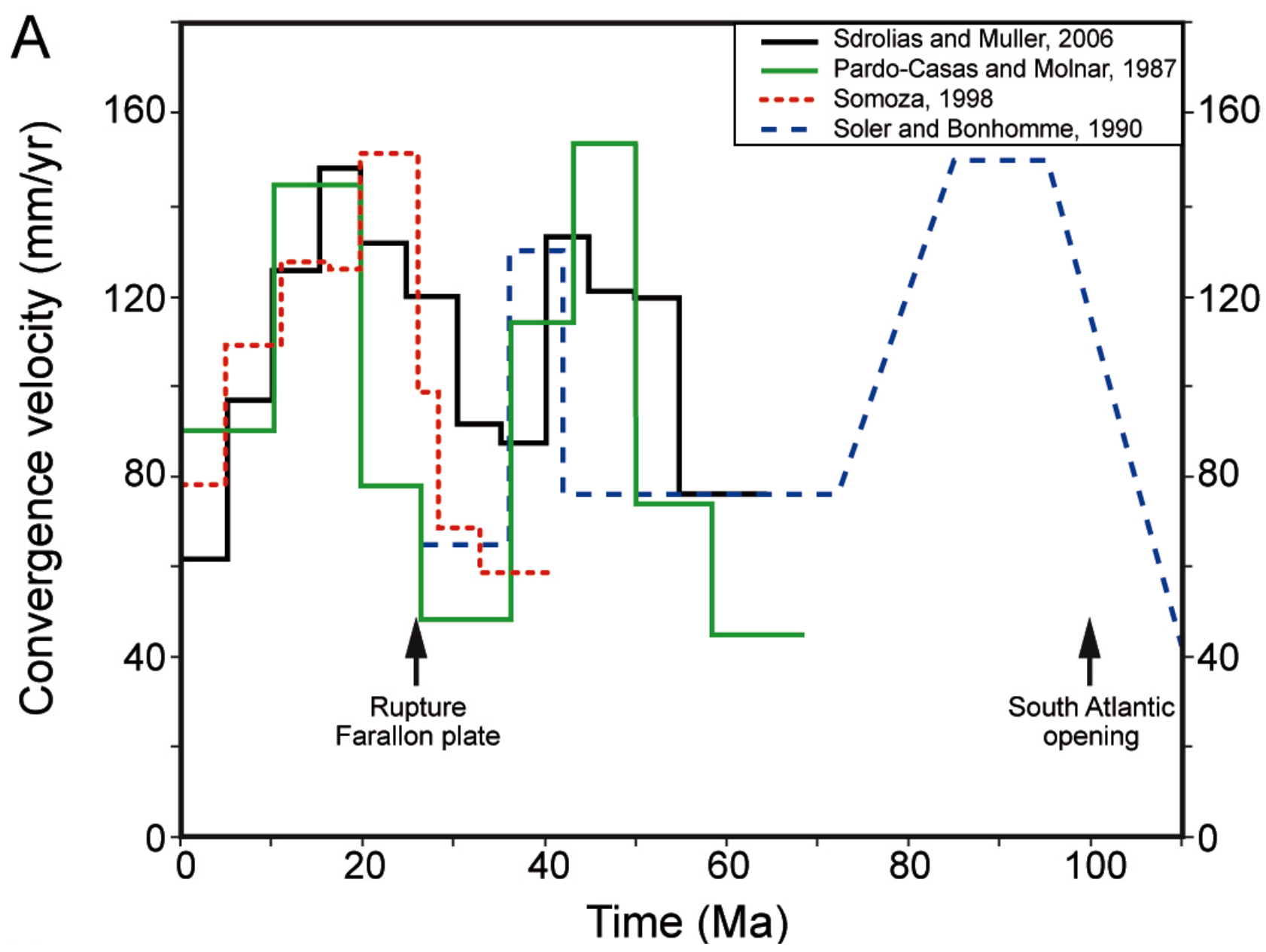

Fig.2. Mean convergence rate between the Nazca-Farallon oceanic plate and South America at around $22^{\circ} \mathrm{S}$ from $100 \mathrm{Ma}$ to present (after Pardo-Casas and Molnar; 1987; Bohomme and Soler, 1990; Somoza, 1998; Sdrolias and Muller, 2006; Martinod et al., 2010). Rapture of the Rarallon plate at 23 Ma (Longsdale 2005). Flat subduction correlates with slower convergence rates.

\subsubsection{Movements of the Nazca and the Juan Fernandez ridge}

\section{Nazca ridge}

The flattening of the slab in northern and central Peru has been proposed as a result of the subducting Nazca Ridge (Gutscher et al., 2000). The collision zone of the $1000 \mathrm{~km}$ long, $200 \mathrm{~km}$ wide and 1,5 km high Nazca Ridge and the Peruvian segment of the convergent South American margin between $14^{\circ} \mathrm{S}$ and $17^{\circ} \mathrm{S}$ resulted in the deformation of the upper plate and a few hundred meters of uplift of the fore-arcs. The ridge has a trend of $\mathrm{N}_{2} 2^{\circ} \mathrm{E}$ at a region where the convergence direction is $77^{\circ}$ resulting in an oblique angle of subduction and southward ridge migration. The a-seismic submarine ridge formed at the Farallon spreading center in the Early Cenozoic (Pilger 1981; Pilger and Handschumacher, 1981; Woods and Okal, 1994; Hampel 2002), whereas the onset of ridge subduction began at $11.2 \mathrm{Ma}$ at $11^{\circ} \mathrm{S}$. The Nazca ridge is oblique with respect to both trench and convergence direction of the Nazca plate and travels southeastwards along the dynamic plate boundary. However, the lateral migration history alongside the Peruvian margin shows that the lateral 
movement of the ridge has slowed through time (of $\sim 75 \mathrm{~mm} / \mathrm{y}$ before $10.8 \mathrm{Ma}$ to $43 \mathrm{~mm} / \mathrm{y}$ from 4.9 to present) due to a small portion of the relative convergence rate concerning the Nazca and South American plates is taken up by intra plate deformation in the Andean mountain belts (Hampel, 2002).

\section{$\underline{\text { Juan Fernández ridge }}$}

In central Chile, the Nazca Plate and Juan Fernández Ridge subducts beneath the South American continental lithosphere from $30^{\circ} \mathrm{S}$ to $35^{\circ} \mathrm{S}$ and extents over $900 \mathrm{~km}$. The Juan Fernández ridge aseismic ridge originates from the stationary Juan Fernández hot-spot. The Juan Fernández ridge began to form at $25 \mathrm{Ma}$ and migrated southwards along the Peru-Chile trench. Reconstruction indicates rapid migration of the collision point along $\sim 1400 \mathrm{~km}$ of the margin from 20 to $11 \mathrm{Ma}$. From $11 \mathrm{Ma}$ to present the collision point has migrated at a slower rate along $\sim 375 \mathrm{~km}$ of the margin. In contrast, during the early Miocene time of the intersection was an order of magnitude faster (Yáñez et al., 2002). Ridge subduction has ever since caused a decrease of the subduction angle, considerable increase in the lithospheric thickness (Pardo et al., 2002) and as well effected the marginal erosion, shoreline indentation and crustal uplift (Fromm et al., 2004). Due to these multiple significant factors the understanding of the migration of the Juan Fernández Ridge is extremely important how it influences volcanic processes.

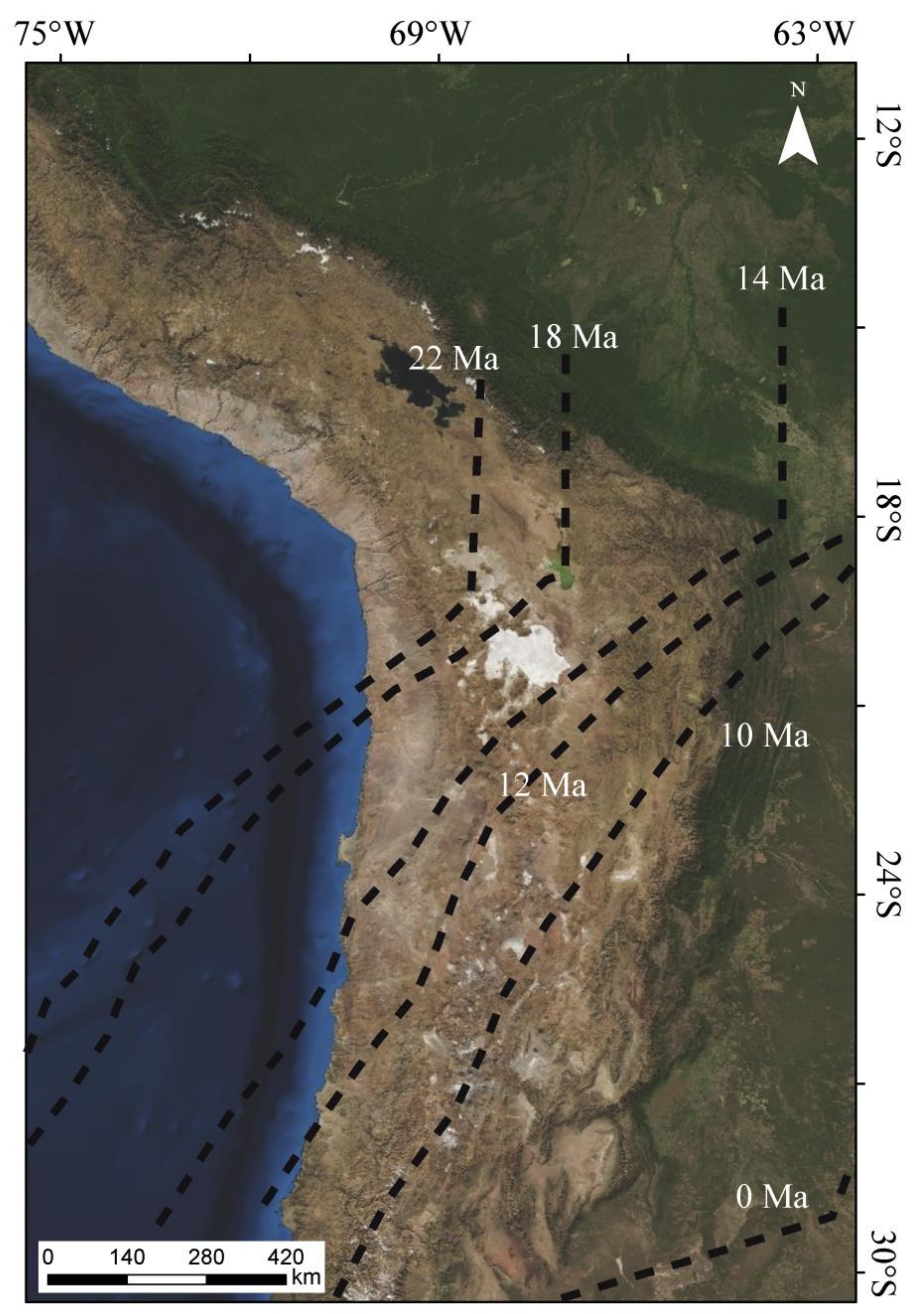

Fig.2. Path of the Juan Fernández ridge during its $\mathrm{N}-\mathrm{S}$ passage beneath the Central Andes in the past 26 Ma: after Yáñez et al., 2002. 


\subsubsection{Uplift}

The history of Andean uplift is crucially important to climatic and tectonic studies, but also effects chemical variations in magma compositions. Despite the long lasting subduction, the uplift started not before the Eocene (Inciac deformation) in the Eastern Cordillera and yet, the start of the uplift at around 35 to $25 \mathrm{Ma}$ in the western Cordillera was in absence of continental collision or terrane accretion (Isacks, 1988; Allmendinger et al., 1997; Sempere et al., 2008). However this first pulse of uplift and the reached elevation is still heavely debated (Anders et al., 2002; Gillis et al., 2006; Gregor-Wodzicki, 2000; Sempere et al., 2008). The onset of uplift was probably due to low angle to nearly flat subduction, which thinned and thermally softened lithosphere (Coira et al., 1993; Kay et al., 1995). A second pulse of uplift has been recongnized around Late Mioceneage starting at approximately $10 \mathrm{Ma}$ (Lamb and Hoke, 1997; Schildgen et al.., 2007; Thouret et al., 2007; Garzione et al., 2008; Sempere et al., 2008).

In a convergence tectonic setting several processes can support elevated terranes. Thus despite the fundamental role of crustal thickening, the processes leading to the $70 \mathrm{~km}$ thick crust is still debated. Thickening of the crust is a combination of crustal shortening (Oncken et al., 2006), compression, crustal underplating, magmatic addition and ductile flow of the lower crust. Besides uplift can be caused by thermal anomalies due to magmatism and mantle plumes and very rigid crust or mantle lithosphere (Gregory-Wodzicki, 2000). Thinning of the lithosphere is a consequence of delamination (Kay and Malburg-Kay, 1991) and tectonic erosion and are a consequence of crustal thickening.

Large amounts of shortening in the Eastern Cordillera and Altiplano can be accounted for between 80 and $90 \%$ of the crustal thickness (Roeder, 1988; Sheffels, 1995; Allmendiger et al., 1997; Baby et al., 1997; Lamb et al., 1997). For the Western Cordillera, magmatic addition contributed 20 to $40 \%$ of the crustal thickness (Schmitz, 1994, Allmendiger et al., 1997; Lamb and Hoke, 1997), however low mean P-wave velocity of the Altiplano crust observed in seismic studies insinuates a felsic composition, which precludes magmatic addition as a major component of crustal thickening (Zandt et al., 1996) and suggests that crustal shortening as the main contribution to crustal thickening. Later Schmitz et al., 1997, rejected this conclusion again based on the observed mean, yet explaining more than $10 \mathrm{~km}$ uplift by magmatic addition seems a bit overestimated. Thus despite years of research still more than $20 \%$ of the crustal thickening remains unexplained.

The contribution of crustal shortening to crustal thickening is not equally distributed but varies along strike. In the Altiplano compression started in the Pliocene between 25 and $29 \mathrm{Ma}$ and continued until about 10-6 Ma. Around 10 - 6 Ma deformation shifted to the east. (Sempere et al., 1990; Allmendinger et al., 1997; Jordan et al., 1997; Lamb et al., 1997). Eocene compression in the Puna region was almost absent in the southern flat slab domain and started much later between 15 and 20 Ma and continued until 1-2 Ma (Allmendinger et al., 1997). However as previously mentioned other 
processes are involved as well and so the estimates of surface uplift based on upper crustal shortening should be considered to have more or less large errors.

Taking all estimates into account (volcanic history, marine and coastal facies, climate history inferred from vegetation, aridity, landscape development history and erosion history) the Western Cordillera reached no more than half of its present height by 18- 25 Ma (Gregory-Wodzicki, 2000). While for the Altiplano it attained about 25-30\% of its modern elevation in the Early Miocene and had reached about half of its modern elevation by $10 \mathrm{Ma}$. These estimates proposes uplift rates of 0.1 $\mathrm{mm} / \mathrm{yr}$ in the early and middle Miocene and increasing to $0.2-0.3 \mathrm{~mm} / \mathrm{yr}$ from the Miocene to the present (Gregory-Wodzicki, 2000).

\subsection{Hypotheses and open questions}

The main focus of this work is to gain insight into the relationship between Miocene lava shields and the younger Pliocene/Quaternary stratovolcanoes. I aim to understand the genesis of their melts and the evolution towards the end products by means of an integrated study on the petrogenesis of lava samples from the Central Andes. Several hypotheses are examined throughout the thesis in order to advance our understanding of the Central Andes with respect to tectonics, mantle wedge geometry, uplift and chemical variations. Some of these topics are already explained above, while others will be elaborated within the main chapters.

The first hypotheses is; the transition between Miocene voluminous lava shields and small Pliocene/Quaternary stratovolcanoes magmatic regimes could be due to a change in (1) the mantle melting regime from decompression to flux melting, (2) rates in magma production and effusion, and (3) the P-T-regimes of magma evolution within the crust reflecting a change in crustal thickness (syn and post thickening).

The main questions that are asked are:

- What are the precise volumetric differences between Miocene shields and Pliocene/Quaternary stratovolcanoes?

- Is there a difference between the melting and crystallization conditions within the mantle, lower and upper crust?

- The sequence of distinct magmatic regimes (plateau-ignimbrites, shield andesites and evolved stratovolcanoes) is diachronous during the past $26 \mathrm{Ma}$ of Central Andean evolution: with ages younging from $\mathrm{N}$ to $\mathrm{S}$, is there a deeper control?

To answer these questions I studied Miocene to modern Central Andean volcanic rocks that represent a variety of ages, petrography, composition, and volcanic style in order to test differences in processes of magma generation. Based on a survey of 1112 chemical analyses (http://andes.gzg.geo.uni-goettingen.de/) I selected three representative sample types, all of which were identified before as important endmember magma type in the Central Andes. Using several 
geothermometers, hygrometers and MELTS modelling (Gulda et al., 2012), I will identify the P-T parameters at the time of crystallization.

The second hypothesis is; Chemical differences through time are caused by crustal thickening. Although this hypothesis is not new, several new issues are addressed.

- How much crustal contamination is needed to form the chemical signatures present in andesites?

- What are the thermodynamic conditions of the recharge magma, assimilation and the pristine magma? And do these vary through time?

- What are the constraints on volumes and eruption rates through time and space?

- What control on chemical signatures has the slab dip, convergence rate, the movement of the overriding plate, strength of mechanical coupling between the subducting and overriding plates, lithospheric structure, magmatic pressure - temperature crystallization conditions, mass and heat fluxes from recharge magma, crustal thickening?

To evaluate chemical variations of lava samples through time, thermodynamic models are vital tools; here I use a combination of MELTS for major elements and EC-RAxFC for trace elements and isotopes to advance the understanding of rates of magma formation and eruptions in the Central Andes.

The third hypothesis is; Major elements can be used in order to differentiate andesites before and after crustal thickening. This hypothesis has been suggested by many authors e.g. (Davidson and de Silva, 1992, 1995; Davidson et al., 1991; Kay et al., 1994, 1996; Wörner et al., 1988, 1992, 1994; Mamani et al., 2010) for trace elements, however by means of traditional diagrams it is hard to distinguish andesites before and after crustal thickening between the major elements.

- Can multivariate statistics discern between effects of differences in end members or source, different degree of assimilation, differentiation, magma mixing and fractional crystallization with respect to before and after crustal thickening?

Here multivariate statistics is tested in order to better understand the control of crustal thickening on major elements and correlate them with the trace element signature. The statistical technique, known as cluster analysis using k-means, is used to correlate and integrate information about relations between major and trace elements. Cluster analysis allows us to identify objectively the major common trends in chemical data and thus to reduce the information to a limited number of characteristic parameter combinations. 


\section{References Cited}

Allmendinger RW, Jordan TE, Key SM, Isacks B (1997) The evolution of the Altiplano Puna plateau of the Central Andes: Annu. Rev. Earth Planet. Sci. 25:139-174

Alemán, A, Ramos VA (2000) Northern Andes. In Tectonic evolution of South America (Cordani, U.G.; Milani, E.J.; Thomaz Filho, A.; Campos, D.A.; editors). Internat Geol Congress.31:453480. Río de Janeiro

Anders MH, Gregory Wodzicki KM, Spiegelman M (2002) A critical evaluation of late Tertiary accelerated uplift rates for the Eastern Cordillera, Central Andes of Bolivia. J. Geol 110: 89-100

Astini RA, Benedetto JL, Vaccari NE (1995) The Early Paleozoic evolution of the Argentine Precordillera as a Laurentian rifted, drifted, and collided terrane: a geodynamic model. Geol. Soc. Am. Bull. 107:253-273

Atherton MP, Sanderson ML, Wander V, McCourt W (1985) The Volcanic Cover: Chemical Composition and the Origin of the Magmas of the Calipuy Group. In Magmatism at a Plate Edge: The Peruvian Andes; Pitcher, W.S., Atherton, M.P., Cobbing, E.J., Beckinsale, R., Eds.; Blackie and Son Ltd: Glasgow and London, UK; John Wiley and Sons: New York, NY, USA 273-284

Baby P, Rochat P, Mascle G, Hérail G (1997) Neogene shortening contribution to crustal thickening in the back arc of the Central Andes: Geol. 25: 883-886

Barazangi M, Isacks B (1979) Subduction of the Nazca plate below Peru: evidence from spatial distribution of earthquakes. Geophys. J. R. Astronom. Soc. 57: 537-555

Beck SL, Zandt G (2002) The nature of orogenic crust in the central Andes. J Geophys Res 107: doi 10.1029/2000JB000124

Benjamin M, Johnson N, Naeser C (1987) Recent rapid uplift in the Bolivian Andes: Evidence from fission-track dating. Geol. 15:680-683

Bosch Mm Rodreiguez I (1992) North Venezuelan collisional crustal block; the boundary between the Caribbean and South American plates: J. S Am. Earth Sci. 6:133-143

Chew D, Magna T, Kirkland C, Miškovič A, Cardona A, Schaltegger U, Spikings R (2008) Detrital zircon fingerprint of the Proto-Andes: Evidences for a Neoproterozoic active margin? Precambrian Res. 167: 186-200

Chew D, Schaltegger U, Kosler J, Whitehouse MJ, Gutjahr M, Spikings R, Miškovič A (2007) U-Pb geochronologic evidence for the evolution of the Gondwana margin of the north-central Andes. Geol. Soc. Am. Bull. 119: 697-771

Coira B, Davidson J, Mpodozis C, Ramos V (1982) Tectonic and magmatic evolution of the Andes of northern Argentina and Chile: Earth Sci. Rev. 18:303-332 
Crowell J (1987) The tectonically active margin of the western U.S.A.. Episodes 10:278-282

Dalziel IWD (1997) Neoproterozoic-Paleozoic geography and tectonics: review, hypothesis, environmental speculation. Geol. Soc. Am. Bull. 109:16-42

Dalziel IWD (1994) Precambrian Scotland as a Laurentia-Gondwana link: Origin and significance of cratonic promontories. Geol. 22:589-592

Damm KW, Harmon RS, Kelley S (1994) Some isotope and geochemical constraints on the origin and

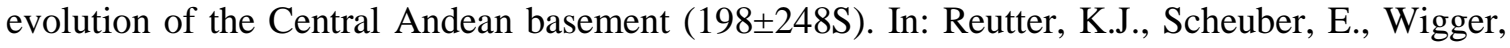
P.J. (Eds.). Tectonics of the Southern Central Andes. Springer, Heidelberg, Germany 263-275.

Damm KW, Pichowiak S, Harmon RS, Todt W, Kelley S, Omarini R, Niemeyer H, (1990) PreMesozoic evolution of the Central Andes: the basement revisited. Geol. Soc. Am. Special Paper 241:101-126

Davidson JP, de Silva SL (1995) Late Cenozoic magmatism of the Bolivian Altiplano. Contrib. Mineral. Petrol. 119: 387 - 408

Davidson JP, De Silva SL (1992) Volcanic rocks from the Bolivian Altiplano: Insights into crustal structure, contamination, and magma genesis in the central Andes. Geol. 20: 1127-1130.

Davidson J, Harmon RSH, Wörner G (1991) The source of Central Andean magmas; some considerations. In: Harmon, Rapela (Eds.), Andean Magmatism and its Tectonic Setting, Geol. Soc. Am. Special Publication, 265: 233 - 243

Espurt N, Funiciello F, Martinod J, Guillaume B, Regard V, Faccenna C, Brusset S (2008) Flat subduction dynamics and deformation of the South American plate: Insights from analog modeling. Tectonics 27: TC3011

Fromm R, Zandt G, Beck SL (2004) Crustal thickness beneath the Andes and Sierras Pampeanas at $30^{\circ} \mathrm{S}$ inferred from Pn apparent phase velocities, Geophys. Res. Lett., 31: L06625, doi:10.1029/2003GL019231

Gansser A (1973) Facts and theories on the Andes. J Geol Soc London. 129: 93-131

Garzione CN, Hoke GD, Libarkin JC, Withers S, MacFadden B, Eiler J, Ghosh P, Mulch A (2008) Rise of the Andes. Science 320: 1304-1307

Gillis RJ, Horton BK, Grove M (2006) Thermochronology, geochronology, and upper crustal structure of the Cordillera Real: Implications for Cenozoic exhu- mation of the central Andean plateau. Tectonics 25: TC6007. doi: 6010.1029/2005TC001887

Gorring ML, Kay SM, Zeitler PK, Ramos VA, Rubiolo D, Fernández MI, Panza JL (1997) Neogene Patagonian plateau lavas: continental magmas associated with ridge collision at the Chile Triple Junction. Tectonics 16:1-17 
Gregory-Wodzicki KM (2000) Uplift history of the Central and Northern Andes: a review. Geol Soc Am Bull 112: 1091-1105

Gubbels T, Isacks B, Farrar E (1993) High-level surfaces, plateau uplift, and foreland development, Bolivian Central Andes. Geol. 21:695-698

Gutscher MA, Spakman W, Bijwaard W, Engdalh ER (2000) Geodynamics of flat subduction: Seismicity and tomographic constraints from the Andean margin, Tectonics 19: 814-833, doi:10.1029/1999TC001152

Hamilton W (1987) Plate tectonic evolution of the western U.S.A. Episodes 10:271-276.

Herron E, Heirtzler J (1967) Seafloor spreading near the Galapagos. Sci. 158:775-780.

Hervé F, Demant A, Ramos VA, Pankhurst RJ, Suárez M (2000) The Southern Andes. In Tectonic evolution of South America (Cordani, U.G.; Milani, E.J.; Thomaz Filho A, Campos DA, editors). Internat Geol Congress. 31: 605-634. Río de Janeiro

Isacks B (1988) Uplift of the Central Andean plateau and bending of the Bolivian orocline. J Geophys Res, Solid Earth and Planets 93:3211-3231

Jaillard E, Hérail G, Monfret T, Díaz-Martínez E, Baby P, Lavenu A, Dumont JF (2000) Tectonic Evolution of the Andes of Ecuador, Peru, Bolivia and Northernmost Chile. In Tectonic Evolution of South America, Proceedings of 31st International Geological Congress, Rio de Janeiro, Brazil, 6-17 August. Cordani, U.G., Milani, E.J., Thomaz, A., Campos, D.A., Eds.; FINEP; Fundo Setorial de Petróleo e Gás Natural: Rio de Janeiro, Brazil: 481-559

James DE, Sacks IS (1999) Cenozoic formation of the Central Andes: a geophysical perspective in Geology and Ore Deposits of the Central Andes: (SpecialPublication) Skinner BJ ed. Littleton. Soc. Of Econom Geol 1:25

Jordan TE, Reynolds JH III, Erikson JP (1997) Variability in age of initial shortening and uplift in the Central Andes, 16-3330'S, in Ruddiman,WF., ed., Tectonic uplift and climate change: New York, Plenum Press:, 41-61

Kay SM, Coira B, Mpodozis C (1995) Neogene magmatic evolution and the shape of the subducting oceanic slab beneath the central Andean arc. IUGG 21th General Assembly, pp.A440. Boulder, CO: Int. Union Geod. Geophys

Kay SM, Coira B, Viramonte J (1994) Young mafic back arc volcanic rocks as indicators of continental lithospheric delamination beneath the Argentine Puna Plateau, Central Andes: J. Geophys. Res. 99 (24) : 323-24,339, doi: 10.1029/94JB00896

Kay SM, Mpodozis C, Coira B (1999) Neogene magmatism, tectonism and mineral deposits of the Central Andes ( ${ }^{\circ} \mathrm{S}$ to $\left.33^{\circ} \mathrm{S}\right)$ : in Skinner B et al., eds: Geology and Mineral Deposits of Central Andes. Soc of Ecomon Geol 2:1-35 
Kay SM, Mpodozis C, Coira B (1996) Central Andean mantle-derived basalts and Neogene mantle enrichment beneath the Puna plateau. In: III International Symposium on Andean Geodynamics, Extended Abstract, Saint Malo, France, 583 - 586

Kennan L, Lamb S, Rundle C, (1995) K-Ar dates from the Altiplano and Cordillera Oriental of Bolivia: implications for Cenozoic stratigraphy and tectonics. J. S Am. Earth Sci 8:163-186

Kley J, Müller S, Tawackoli S, Jacobshagen V, Manutsoglu E (1997) Pre-Andean and Andean-age deformation in the Eastern Cordillera of southern Bolivia. J. S Am. Earth Sci. 10:1-19

Kley J, Monaldi CR (1998) Tectonic shortening and crustal thickness in the Central Andes: How good is the correlation? Geol. 26:723-726

Lamb S, Hoke L (1997) Origin of the high plateau in the Central Andes, Bolivia, South America: Tectonics, 16: 623-649

Lamb S, Hoke L, Kennan L, Dewey J (1997) Cenozoic evolution of the Central Andes in Bolivia and northern Chile, in Burg, J.-P., and Ford, M., eds., Orogeny through time: Geol. Soc. London Special Publication .121:237-264

Loewy SL, Connelly JN, Dalziel IWD (2004) An orphaned basement block: The Arequipa-Antofalla Basement of the central Andean margin of South America. Geol. Soc. Am. Bull.116:171-187

Lonsdale P, Klitgord KD (1978) Structure and Tectonic History of Eastern Panama Basin, Geol Soc Am Bull. 89: 981-999

Lowrie A, Hey R (1981) Geological and geophysical variations along the western margin of Chile near lat $33^{\circ}$ to $36^{\circ} \mathrm{S}$ and their relation to Nazca Plate subduction, in Nazca Plate: Crustal Formation and Andean Convergence, Mem., Geol. Soc. Am. Mem. 154:741-754

Lucassen F, Becchio R, Kasemann S, Franz G, Trumbull R, Wilke H, Romer R, Dulski F (2001) Composition and density model of the continental crust at an active continental margin- the Central Andes between $21^{\circ}$ and $27^{\circ}$ S. Tectonophysics. 341:195-223

Lucassen F, Thirlwall MF (1998) Sm-Nd formation ages and mineral ages in metabasites from the Coastal Cordillera, northern Chile. Geol Rundschau 86:767-774

Mamani M, Wörner G, Sempere T (2010) Geochemical variations in igneous rocks of the Central Andean orocline (13 S to $18 \mathrm{~S}$ ): Tracing crustal thickening and magma generation through time and space. Geol. Soc. Am. Bull. 122: 162-182

Mammerickx J, Klitgord K (1982) Northern East Pacific rise: evolution from 25 my to the present. J. Geophys. Res. 87:6751-6759

Martinod J,Hussen L, Roperch P, Guillame B, Espurt N (2010) Horizontal subduction zones, convergence velocity and the building of the Andes. Earth and Planet Sci Lett. 299: 299- 309 
Mayes C, Lawver L, Sandwell D (1990) Tectonic history and new isochron chart of the South Pacific. J. Geophys. Res. 95:8543-8567

Miškovič A, Spikings R, Chew DM, Košler J, Ulianov A, Schaltegger (2009) U. Tectonomagmatic evolution of Eastern Amazonia: Geochemical characterization and zircon U-Pb geochronologic constraints from the Peruvian Eastern Cordillera granitoids. Geol. Soc. Am. Bull. 121, 1298-1324

Miškovič A, Schaltegger (2009)U. Crustal growth along non-collisional cratonic margin: A Lu-Hf isotopic survey of the Eastern Cordillera granitoids of Peru. Earth Planet. Sci. Lett. 279, 303-315

Mpodozis C, Ramos VA (1990) The Andes of Chile and Argentina. In Geology of the Andes and its relation to hydrocarbon and mineral resources (Ericksen GE, Pinochet MTC, Reinemund JA, editors). Circum-Pacific Council for Energy and Mineral Resources, Earth Science Series, 59-90

Oncken O, Hindle D, Kley J, Elger P, Victor P, Schemmann K (2006), Deformation of the Central Andean Upper Plate System - Facts, Fiction, and Constraints for Plateau Models, in The Andes, edited by O. Oncken, et al. Springer 3-28

Pardo M Comte D, Monfret T (2002) Seismotectonic and stress distribution in the central Chile subduction zone, J. South Am. Earth Sci., 15(1):11-22, doi:10.1016/S0895-9811(02)00003-2

Pardo-Casas F, Molnar P (1987) Relative motion of the Nazca (Farallon) and south American plates since Late Cretaceous time. Tectonics 6: 233-248

Pilger RH (1981) Plate reconstructions, aseismic ridges, and low-angle subduction beneath the Andes. Geol. Soc. Am. Bull. 92: 448-456

Pilger RH, Handschumacher DW (1981) The fixed hotspot hypothesis and origin of the Easter-Salas y Gomez-Nazca trace. Geol. Soc. Am. Bull. 92:437-446

Rogers G, Hawkesworth CJ (1989) Reply to comment of C.R. Stern on "A geochemical traverse across North Chilean Andes: evidence for crust generation from the mantle wedge" Earth Planet. Sci. Lett. 101 (1990: 134-137

Ramos VA (2000) The southern Central Andes. In Tectonic evolution of South America (Cordani, U.G.; Milani, E.J.; Thomaz Filho, A.; Campos, D.A.; editors). Internat Geol Congress. 31: 561604. Río de Janeiro

Ramos VA (1988) Late Proterozoic-early Paleozoic of South America: a collisional history. Episodes, $1: 168-174$

Ramos VA (1995) Sudamerica: un mosaico de continentes y oceanos. Ciencia hoy 6 32:24-29

Ramos VA, Aleman A (2000) Tectonic Evolution of the Andes, in Cordani, U., Milani, E.J., Thomaz Filho, A., and Campos Neto, M.C., eds., Tectonic Evolution of South America: Rio de Janeiro, p. 635-685 
Ramos VA, Kay SM (1992) The Southern Patagonian plateau basalts: retroarc testimony of a ridge collision, Argentina: in Oliver RA, Vatin-Perignon N, Laubacher G, eds. Andean Geodynamics Symposium, Geroboble. Tectonophysics 205:261-282

Roeder D (1988) Andean-age structure of Eastern Cordillera (Province of La Paz, Bolivia). Tectonics 7:23-39

Schildgen TF, Hodges KV, Whipple KX, Reiners PW, Pringle MS (2007) Uplift of the western margin of the Andean plateau revealed from canyon incision history, southern Peru. Geol 35: $523-526$

Schmitz M (1994) A balanced model of the southern Central Andes: Tectonics, 13:484-492

Sdrolias M, Muller RD (2006) Controls on back-arc basin formation, Geochem Geophys Geosys 7

Sempere T, Folguera A, Gerbault M (2008) New insights into Andean evolution: an introduction to contributions from the 6th ISAG symposium (Barcelona, 2005). Tectonophysics 459: 1-13

Sempere T, Hérail G, Oller J, Bonhomme MG (1990) Late Oligocene-early Miocene major tectonic crisis and related basins in Bolivia: Geol. 18:946-949

Sérbrier M, Soler P (1991) Tectonics and magmatism in the Peruvian Andes from Late Oligocene time to the present: in Harmon RS, Rapela CW, eds. Andean magmatism and its tectonic setting. Geol. Soc. Am. Special Paper 265:259-276

Sheffels BM (1995) Mountain building in the Central Andes: An assessment of the contribution of crustal shortening: Internat. Geol Rev. 37:128-153

Soler P, Bonhomme MG (1990) Relation of Magmatic Activity to Plate Dynamics in Central Peru from Late Cretaceous to Present. In Plutonism from Antarctica to Alaska; Special Paper 241; Kay, S.M., Rapela, C.W., Eds.; Geol. Soc. Am. Boulder, CO, USA. 173-192

Somoza R (1998) Updated Nazca (Farallon)-South America relative motions during the last 40 My: implications for the mountain building in the central Andean region: J. S Am. Earth Sci. 11:211215

Stern CR (2004) Active Andean volcanism: its geologic and tectonic setting. Revista Geol Chile 31: 161-206 doi: 10.4067/O716-02082004000200001

Tassara A, Yáñez G (20ts03) Relación entre el espesor elástico de la litosfera y la segmentación

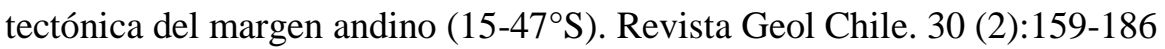

Tebbens S, Cande S (1997) Southeast Pacific tectonic evolution from Early Oligocene to present. J. Geophys. Res. 102:12061-12084

Tebbens S, Cande S, Kovacs L, Parra J, LaBrecque J, Vergara H (1997) The Chile ridge: a tectonic framework. J. Geophys. Res. 102:12035-12059 
Thouret JC, Wörner G, Gunnel Y, Singer B, Zhang X, Souriot T (2007) Geochronologic and stratigraphic constraints on canyon incision and Miocene uplift of the Central Andes in Peru. Earth Planet Sci Lett 263:151-166

Tosdal RM (1996) The Amazon-Laurentian connection as viewed from the Middle Proterozoic rocks in the Central Andes, western Peru and Northern Chile. Tectonics. 15:827-842.

Unrug R (1996) The assembly of Gondwanaland. Episodes 19: 11-20

Wasteneys HA, Clark AH, Farrar E, Langridge RJ (1995) Grenvillian granulite-facies metamorphism in the Arequipa Massif, Peru: A Laurentia-Gondwana link. Earth and Planetary Science Letters. $132: 63-73$

Woods MT, Okal EA (1994) The structure of the Nazca Ridge and Sala y Gomez seamount chain from dispersion of Rayleigh waves. Geophys. J. Int. 117:205-222

Wörner G, Lezaun J, Beck A, Heber V, Lucassen F, Zinngrebe E, Röbling R, Wilke HG (2000) Precambrian and Early Paleozoic evolution of Andean basement at Belén (northern Chile) and Cerro Uyarani (western Bolivian Altiplano). J. S Am. Earth Sci. 13:717-737

Wörner G, Harmon RS, Davison JD, Moorbath S, Turner TL, McMillan N, Nye C, López-Escobar L. Moreno H, (1988) The Nevados de Payachata volcanic region $18^{\circ} \mathrm{S} / 69^{\circ} \mathrm{W}$, N. Chile. I. Geological, geochemical and isotopic observations: Bull. Volcanol. 50: 287-303, doi: 10.1007/ BF01073587

Wörner G, Moorbath S, Harmon RS (1992), Andean Cenozoic volcanics refl ect basement isotopic domains: Geol. 20: 1103-1106, doi: 10.1130/ 0091-7613

Wörner G, Moorbath S, Horn S, Entemann J, Harmon RS, Davidson JP, López-Escobar L (1994) Large- and fine-scale geochemical variations along the Andean arc of northern Chile (17.5 - 22 S). In: Reutter KJ, Scheuber E, Wigger PJ (Eds.), Tectonics of the Southern Central Andes. Structure and Evolution of an Active Continental Margin. Springer. 77 - 92

Yáñez G, Cembrano J, Pardo M, Ranero C, Selles D (2002) The Challenger-Juan Fernández-Maipo major tectonic transition of the Nazca-Andean subduction system at $33^{\circ}-34^{\circ} \mathrm{S}$ : Geodynamic evidence and implications, J. South Am. Earth Sci., 15(1):23-28, doi:10.1016/ S08959811(02)00004-4

Zandt G, Beck SL, Ruppert SR, Ammon CJ, Rock D, Minaya E, Wallace TC, Silver PG (1996) Anomalous crust of the Bolivian Altiplano, Central Andes: Constraints from broadband regional seismic waveforms: Geophys Research Lett 23: 1159-1162 


\section{Chapter 2}

\section{Constraints on P-T conditions of crystallization and rates of magma formation before and after crustal thickening in the Central Andes}

\section{Abstract}

Miocene volcanoes in the Central Andes typically overlie regionally extensive plateau-forming ignimbrites (22 - $20 \mathrm{Ma}$ ) (Thouret et al., 2007; Noble and Farrar, 1979). These "early" lavas typically form low-angle, large-volume volcanic shields with long single lava flows up to $20 \mathrm{~km}$ (ranging from 0.03 to $9 \mathrm{~km}^{3}$ per lava flow with an average of $1.85 \mathrm{~km}^{3}$ ), and have compositions varying from andesites to dacites, with plagioclase + pyroxene \pm olivine as the most abundant phases. These volcanic shields are succeeded by younger ("late") and more evolved steep-sided stratocones that presently characterize much of the CVZ active volcanic front. The younger Pliocene-Quaternary stratovolcanoes have individual lava flow volumues in a similar range from about 0.01 to $8.5 \mathrm{~km}^{3}$ however, have a much lower average of $0.7 \mathrm{~km}^{3}$. In addition amphibole phenocrysts are more abundant at similar $\mathrm{SiO}_{2}$ contents. The transition between these magmatic regimes could be due to a change in (1) the mantle melting regime from decompression (hot and dry?) to flux melting (wet and lower T?), (2) rates in magma production and effusion, and (3) the P-T-regimes of magma evolution within the crust reflecting a change in crustal thickness (syn and post thickening).

The sequence of distinct magmatic regimes (plateau-ignimbrites, shield andesites and evolved stratovolcanoes) is diachronous during the past 26 Ma of Central Andean evolution with ages for the triplet younging from $\mathrm{N}$ to $\mathrm{S}$. This suggests control by "deeper" processes guided by the geometry of the slab, the thermal evolution of the upper plate during Andean orogeny, and the movement of the Juan Fernández Ridge. Critical factors, such as subduction parameters and magma production rates in the mantle wedge all change regionally and temporally during ongoing thickening of the Central Andean crust and the passage of the Juan Fernández Ridge. In addition, the upper plate reacts locally to these changes according to its thermal state at the time, crustal composition, and tectonic stress conditions.

I studied Miocene to modern Central Andean volcanic rocks that represent a variety of ages, petrography, composition, and volcanic style in order to test differences in processes of magma generation. Based on a survey of 1112 chemical analyses (http://andes.gzg.geo.uni-goettingen.de/) I 
Chapter 2 - Constraints on P-T conditions of crystallization and rates of magma formation before and after crustal thickening in the Central Andes

selected three representative sample types, all of which were identified before as important endmember magma type in the Central Andes (Banaszak, 2014). Using several geothermometers, hygrometers and MELTS modelling (Gulda et al., 2012; Asimow and Ghiorso, 1998; Ghiorso and Sack, 1995), I show that the P-T conditions of crystallization of these andesitic magmas remained surprisingly constant trough time and space in the Central Andes. For example, the depth of crystallization of phenocrysts in both Miocene to Present magmas took place between 9 and $3.5 \mathrm{~km}$ throughout Andean history, in spite of significant crustal thickening and trace element evidence for an increasing high pressure (garnet) signature during magma evolution in younger magmas (Kay et al., 1991, 2005; Haschke et al., 2002; Mamani et al., 2010) Apparently, deep processes that control magma trace element signatures are completely decoupled from the conditions of phenocryst formation. These observations argue for a more general control on the differences in eruptive style between Miocene and Pliocene-Quaternary volcanic edifices, such as density, viscosity, and a general regime of magma mixing. The thickened upper crust not only serves as a chemical filter for mantle wedge magmas. Accordingly, any distinct regimes of magma formation in the mantle wedge are almost entirely dampened out during the passage through the crust. Only the rate of effusion and by implication, magma production and upper crustal stress regime remain as primary factors that may have influenced differences between Miocene and Recent magmatic products.

\subsection{Introduction}

The Andean orogenic chain forms the western margin of the South American continent, parallel to a subduction zone where the Nazca oceanic plate descends beneath the South American continental plate. The Central Volcanic Zone (CVZ) is part of this active margin, where subduction has taken place since late Jurassic times. During the Late Cretaceous, long-term compression seems to have been controlled by absolute trenchward motion of the overriding plate and to a minor extent, by the young age of the subducted lithosphere (Jaillard et al., 1996; Mpodzis et al., 2005; Quinteros and Sobolev, 2012), being almost parallel or highly oblique subduction to the continent.

Throughout the Oligocene, a change in plate tectonic forces resulted from an abrupt increase in convergence rate and the change in the direction of subduction, (being more perpendicular to the continent) were not effective in sustaining the motion of the Farallon plate and created high intra-plate stresses (Soler and Bonhomme, 1988; Soler, 1990; Somoza, 1998). Approximately at the same time the Cocos and Nazca plates formed from the breakup of the Farallon plate (Herron and Heirtzler, 1967; Mammerickx and Klitgord, 1982). At this time (30-26 Ma) the angle of the subducting slab was relatively shallow, $<30^{\circ}$ (Kay and Coira, 2009; Allmendinger et al., 1997) at the Altiplano-Puna plateau and transitions into the Peruvian and Chilean flat slab. Consequently, magma production ceased completely because no hot mantle wedge existed between the subducting and overriding plate (Isacks 1988; Gutscher et al., 2000; Wörner et al., 2000; Wörner et al., 2002; van Hunen et al., 2004; 
Chapter 2 - Constraints on P-T conditions of crystallization and rates of magma formation before and after crustal thickening in the Central Andes

Trumbull et al., 2006; Manea et al., 2012). However, the Altiplano-Puna plateau formation and transitions into the Peruvian and Chilean flat slab were not synchronous due to the southward migration of the intersection of the trench and the Juan Fernández ridge (Yáñez et al., 2001, 2002).

The increase in convergence rate continued until the Early Miocene and gradually slowed during the Late Neogene and can be roughly correlated with the last deformational phase in the orogeny. Besides an increase in convergence rate, a gradual increase of slab dip took place after $25 \mathrm{Ma}$ (Coira et al., 1993; Allmendinger et al, 1997; Kay et al., 1999; Hoke and Lamb, 2007; Kay and Coira, 2009).

Because the type of volcanism can be strongly correlated to changes in convergence rate, slab and mantle wedge geometry, and because the thickness of the crust has increased trough time, the Central Andes are an excellent natural observatory to study the interaction between these parameters. Aside from numerous large volcanic lava fields and stratocones that have formed throughout the evolution of the Andean during the past $30 \mathrm{Ma}$, the CVZ includes one of the largest ignimbrite fields in South America. Plateau-forming events of large volumes of silicic ignimbrites were erupted in relatively short periods that punctuate the geological evolution of the Central Andes. Andesitic magmatism that followed the diachronous emplacement of these ignimbrites ( $>20$ to $<10 \mathrm{Ma}$ ) is characterised for several millions of years by intermediate composition lava flows which vary from basaltic andesites to dacites, with plagioclase + pyroxene \pm olivine as the most abundant phases. Basalts and rhyolites are exceedingly rare. These Miocene volcanoes typically form large, low-angle andesite shield volcanoes and comprise a great number of poorly known, poorly accessible edifices (Fig. 1, 2 and 4). After this, volcanism became generally more silicic and more compositionally variable. Andesites in younger stratovolcanoes are often characterized by amphibole phenocrysts and dacites and rhyolites become more abundant. Together they form the steep-sided stratocones that characterize much of the CVZ active volcanic front today (Fig. 1, 2B and 4B) From this, two important observations can be made (1) a pattern of changing andesites eruption types (difference in volumes) following the ignimbrites and (2) a change within magma composition with a focus on the occurrence of amphiboles. Both observations are dichronous with a younging from north to south. In some rare well-studied volcanic centers (Grunder et al., 2008, Klemetti and Grunder, 2008, Matteini et al., 2002 and Gioncada et al., 2006), the transition in time from rather aphyric plag-px andesites to amphibole-bearing andesites has been documented in detail, at least locally. However, other examples of a reverse evolution have also been documented (Wörner et al., 1988; Hora et al., 2007).

The transition between these magmatic regimes could be due to:

(1) a change in the mantle melting regime from decompression to flux melting. The older Miocene samples could be considered more or less dry (lack amphibole) and hot (large volcanic fields), whereas the younger stratovolcanoes as wet (amphibole bearing) and colder (cover relative a small area). The formation of arc magmas is generally believed to be generated by the release of fluids by the subducting plate into, and melting of, the mantle wedge since fluids depress the solidus of the 
Chapter 2 - Constraints on P-T conditions of crystallization and rates of magma formation before and after crustal thickening in the Central Andes

mantle wedge and induce melting. However, low fluid concentrations have also been found in volcanic arc settings at the Cascades in the western USA and at Galunggung in Indonesia (Cameron et al., 2002) indicating that anhydrous melting due to decompression may also play a role. In such low volatile magmas the stability of amphibole is reduced and temperatures may be higher than in fluxmelted magmas for a given composition. Sisson et al., (1996) and Jagoutz et al., (2011) suggested that hydrous and anhydrous melts intrude at different depths and have two different fractionation trends: hydrous fractionation in the lower crust with high $\mathrm{SiO}_{2}$ and dry fractionation which are derived by dense mafic intrusions near the base of the crust. The transition from anhydrous to hydrous andesites in a subduction setting may be due to the change from mantle decompression resulting from subduction induced corner flow (Elkins-Tanton et al., 2001; Hasegawa and Nakajima, 2004) that is strongly enhanced due to the slab steepening, to partial melting in the mantle wedge, where primary mafic magmas form, by addition of $\mathrm{H}_{2} \mathrm{O}$-rich fluids or melts released from the subducting slab (Ulmer 2001; Grove et al., 2002).

(2) Different rates in magma production and effusion: high effusion rates in the Miocene would lead to the extensive and simple lava flows, a decrease in effusion rate could explain the small compound lava flows which represent most of the Pliocene-Quaternary volcanism. The flow length can be linked to effusion rather than viscosity and seems to be the primary factor controlling not only flow length but also flow field type (Walker, 1973; Harris and Rowland, 2007). Higher effusion rates would lead to long simple flows, while lower effusion rates would create compound short flows that pile up around the vent.

(3) A shift in P-T-regimes of magma evolution within the crust as a function of crustal thickness. Rare earth elements (HREE and Y) show depletion in Miocene to Pleistocene volcanic rock and are due to garnet-residual crustal assimilation in a thickened crust (Kay et al., 1994, 1996; Mamani et al., 2010) and thus suggest an increase in pressure regime with time.

In order to get constraints on all three possible processes, the most significant parameters (temperature, pressure, $\mathrm{H}_{2} \mathrm{O}$, density, viscosity, $\mathrm{fO}_{2}$ and volumes) that may control different flow types were determined by a range of geothermometers, hygrometers, barometers and thermodynamic models on olivines, ortho-, clinopyroxenes, plagioclase, amphiboles and oxides. Since the andesites typically contain a significant fraction of disequilibrium crystals, petrographic evidence indicative of mixing/mingling between silicic and mafic magmas, such as plagioclase crystal size distribution and compositions, were also analyzed in order to get a better understanding of how strongly magma mixing processes between end members can influence the above-mentioned parameters. 


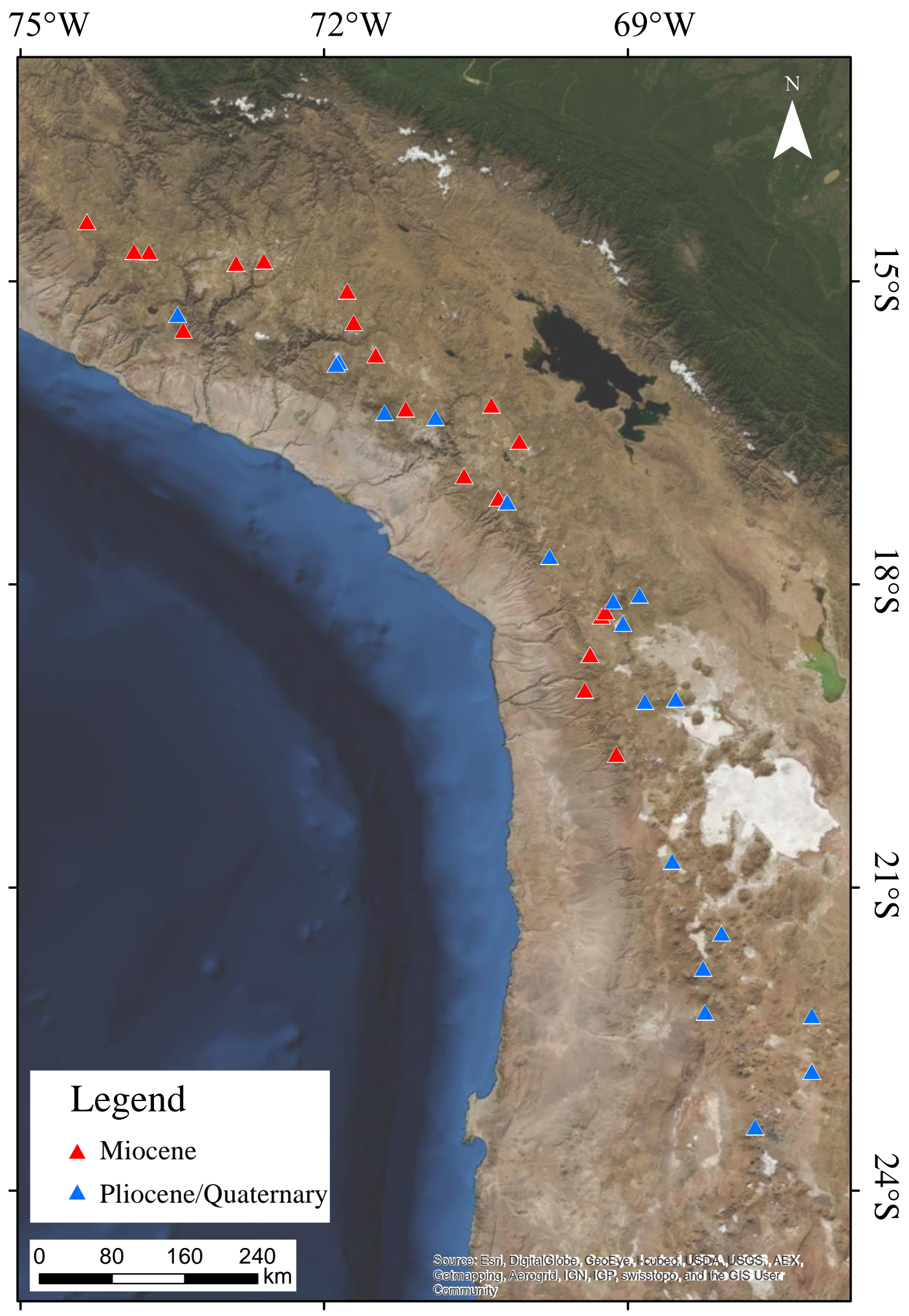

Fig. 1: Map of the Central Andes, indicating the geographic distribution of the profile locations shown in figures. 2- 5. Source: Esri, DigitalGlobe, GeoEye, i-cubed, USDA, USGS, AEX, Getmapping, Aerogrid, IGN, IGP, swisstopo, and the GIS User Community. 
Chapter 2 - Constraints on P-T conditions of crystallization and rates of magma formation before and after crustal thickening in the Central Andes

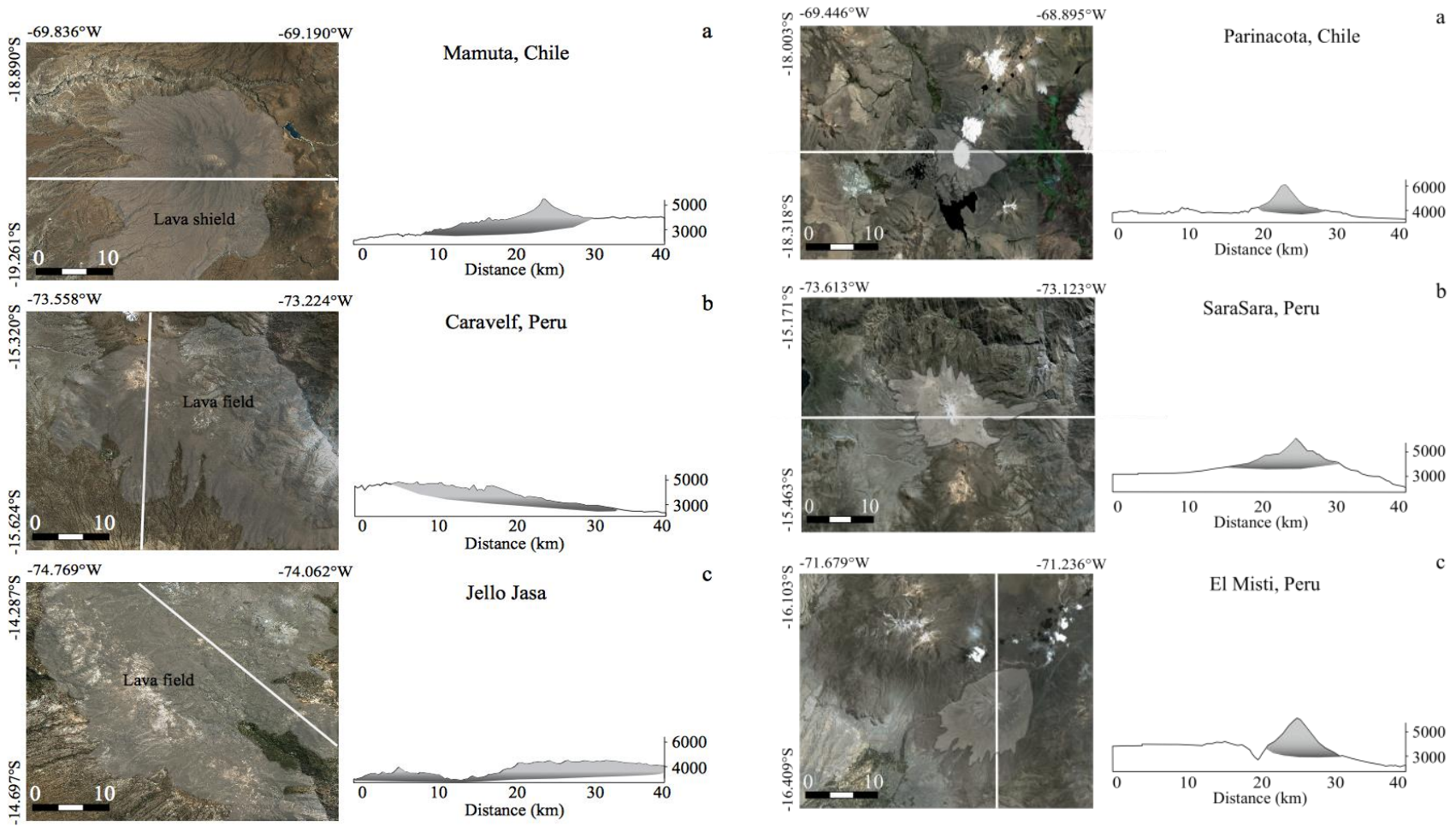

Fig. 2A (left): Conspicuously flat-lying andesite lava shields and fields covering plateau-forming ignimbrites of different ages in southern Peru and northernmost Chile of Miocene age. (a) Mamuta, Chile. Ages range from 7.4 to 10.4 Ma (Mamani et al., 2010). (b) Caracelf, age of lavas Barosso. Samples YAH-00-16, MIO-12-39 and MIO-12-40 (c) Jello Jasa, Peru, age of lava Barosso, samples MIO-12-01 and MIO-12-02.

Fig. 2B (right): Examples of steep-sided compound modern with compositions ranging from mafic andesite to rhyolite of different ages. (a) Parinacota Volcano. Erupted compositions range from basaltic andesite to amphibole andesites and rhyolitic domes (Wörner et al., 2000; Hora et al., 2007, 2009) Ages range from 180 Ka to present. (b) SaraSara Volcano. Compositions range from amphibole andesites and rhyolites (Mamani et al., 2008) Ages range between 1.2 Ma and ca 100 Ka (Wörner et al., 2000; Kaneoka and Guevara, 1984). (c) El Misti Volcano. Composition range from mafic andesite to rare rhyolite and has ages from $120 \mathrm{Ka}$ to present (Thouret at al., 2001). Note that the scale of images the same in both Fig. 2A and $2 \mathrm{~B}$, emphasizing the differences between post-ignimbrite lava fields and modern stratovolcanoes.

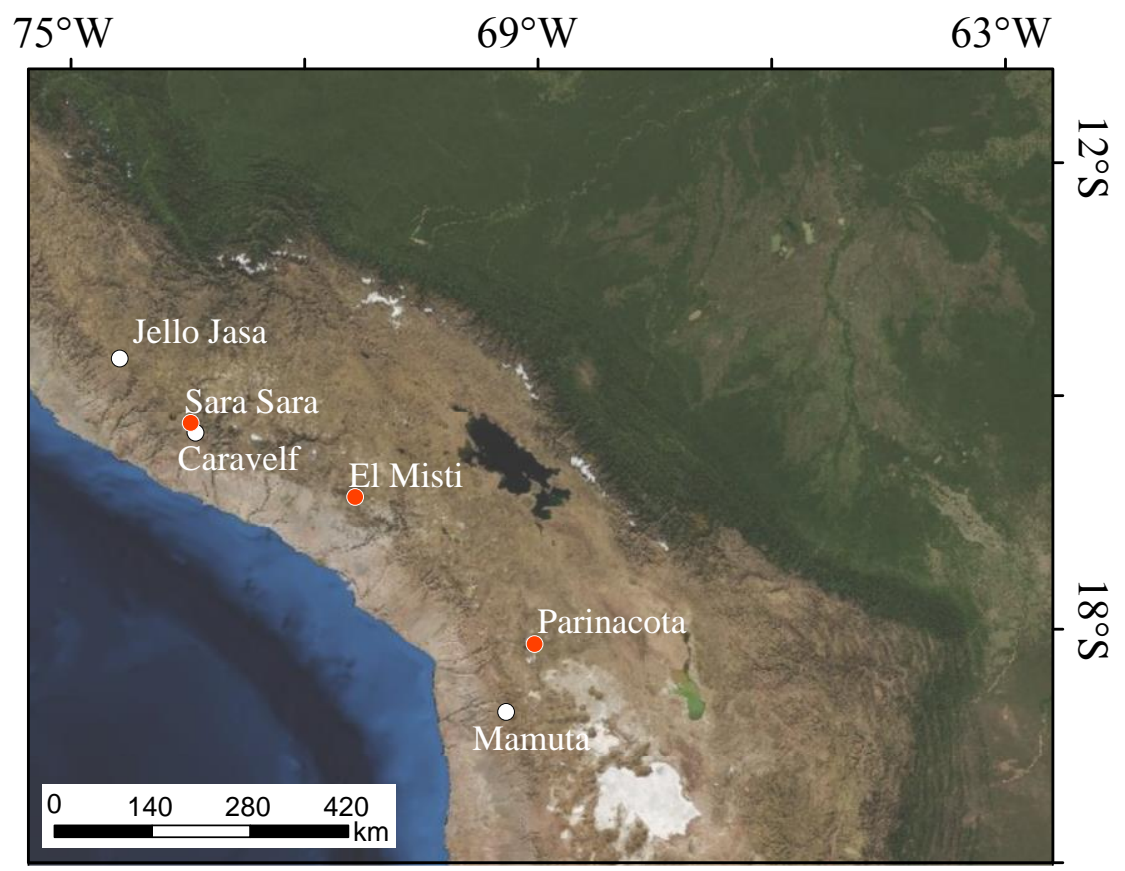

Fig. 3. Profile locations of flat lying andesite lava shields (white) and steep sided stratovolcanoes (red) of figures $2 \mathrm{~A}$ and $\mathrm{B}$. 
Chapter 2 - Constraints on P-T conditions of crystallization and rates of magma formation before and after crustal thickening in the Central Andes

Height $(\mathrm{m})$

Height (m)

Height (m)

Height ( $m$ )

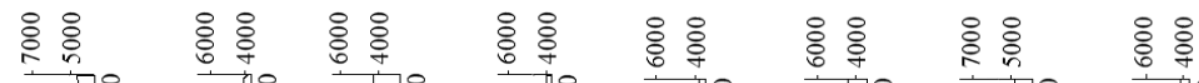

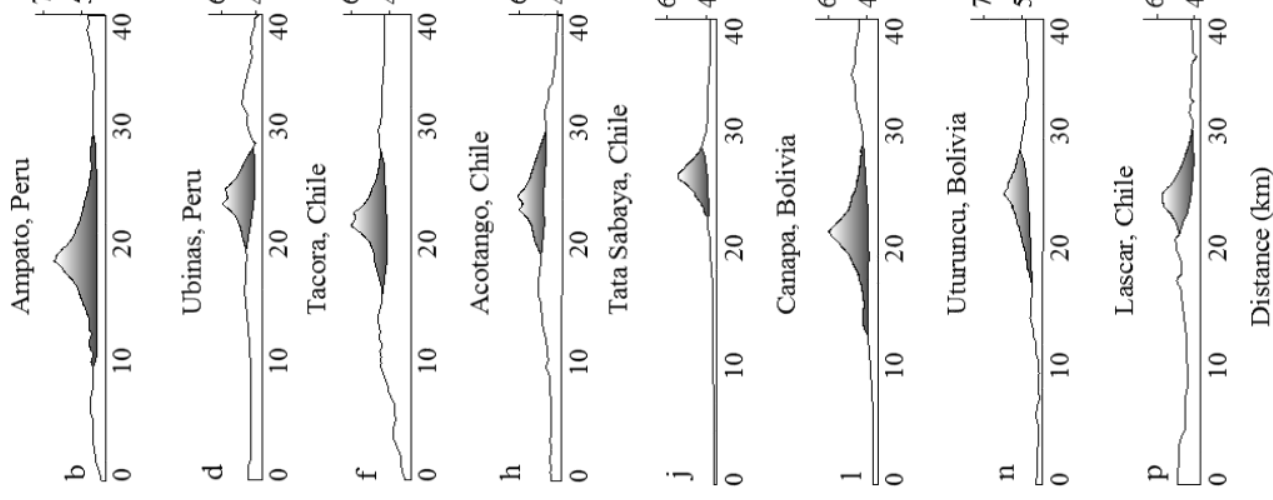

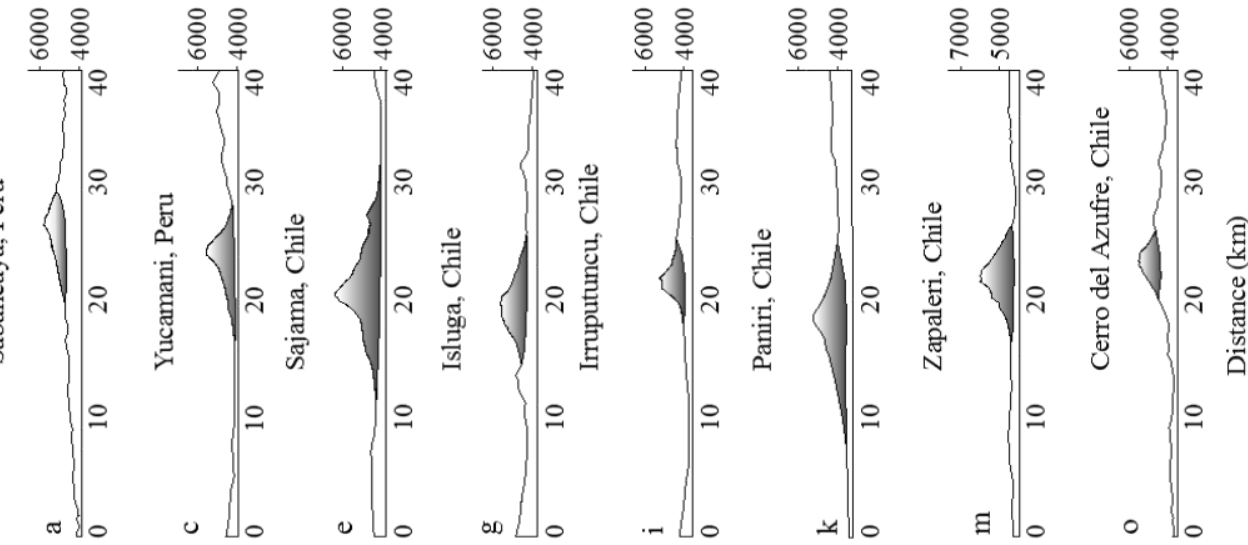

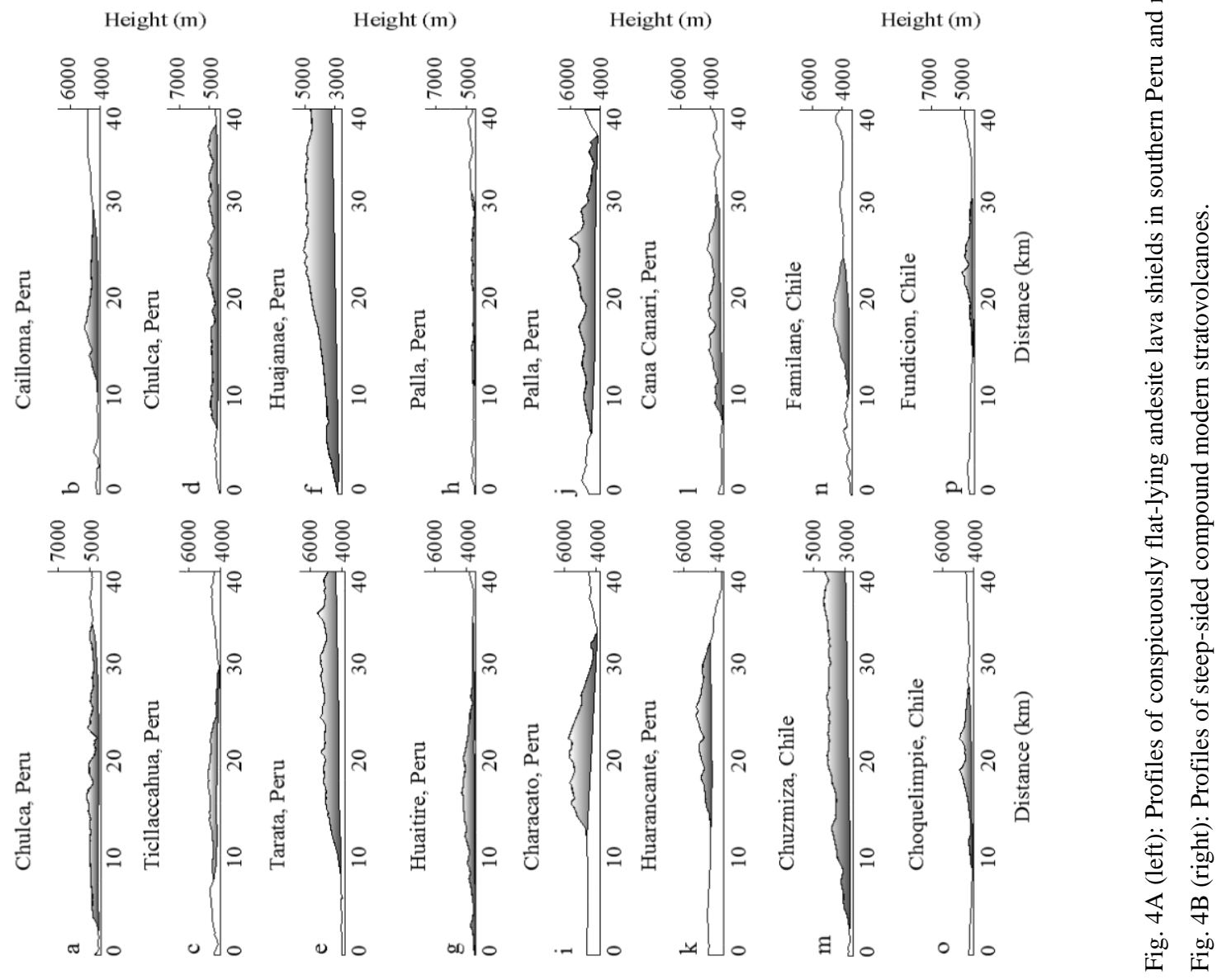


Chapter 2 - Constraints on P-T conditions of crystallization and rates of magma formation before and after crustal thickening
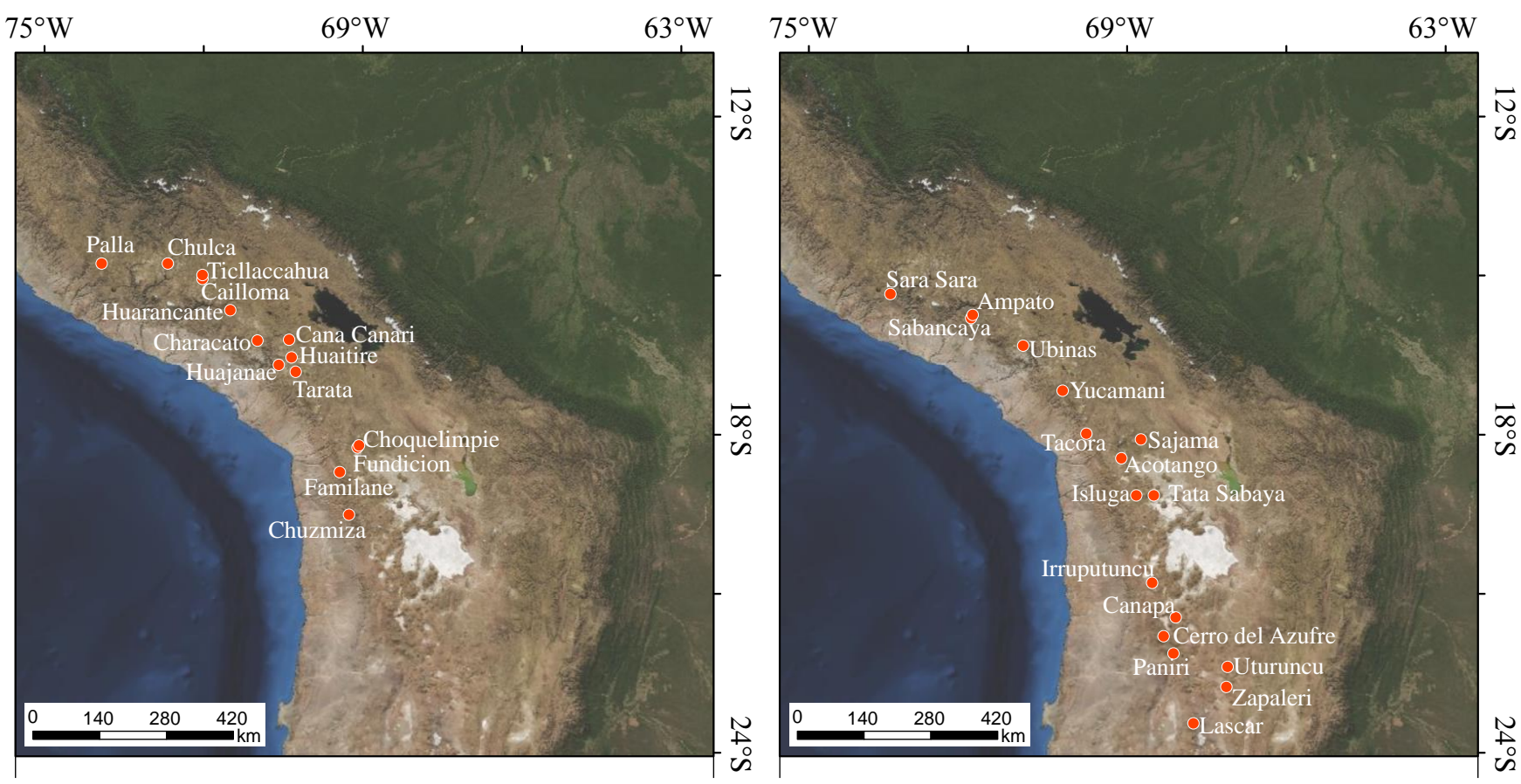

Fig. 5. Profile locations of flat lying andesite lava shields (Left: white symbols) and steep sided stratovolcanoes (right: red symbols) of figures $3 \mathrm{~A}$ and $\mathrm{B}$.

\subsection{Methods}

\subsubsection{Sample selection}

I studied samples that represent different ages, petrography, composition, and volcanic styles in order to test differences in processes of magma generation. I surveyed $>1112$ chemical analyses of lava samples (http://andes.gzg.geo.uni-goettingen.de/) based on petrography, composition, and the distribution of $\mathrm{SiO}_{2}$, I selected three representative sample types of Miocene age. Mio-50, the most mafic samples ranging from 50-55 $\mathrm{wt} \% \mathrm{SiO}_{2}$, Mio-55 are the intermediate andesites with a silica content of 55-60 wt\% and Mio-60 felsic samples with 60-65 wt\% $\mathrm{SiO}_{2}$. Two more groups were selected of Pliocene - Quaternary age, Plio-55 and Plio-60, with approximately the same silica content as Mio-55 and 60 respectively. Due to a lack of basaltic samples of Pliocene - Quaternary age (Plio50) this group has only been included for geothermobarometry. For each group I have selected specimens representing different areas of the Andes (Fig. 6). The choice of samples was to compare rocks that are similar in major element composition but different in age and petrographic aspect (see below). 


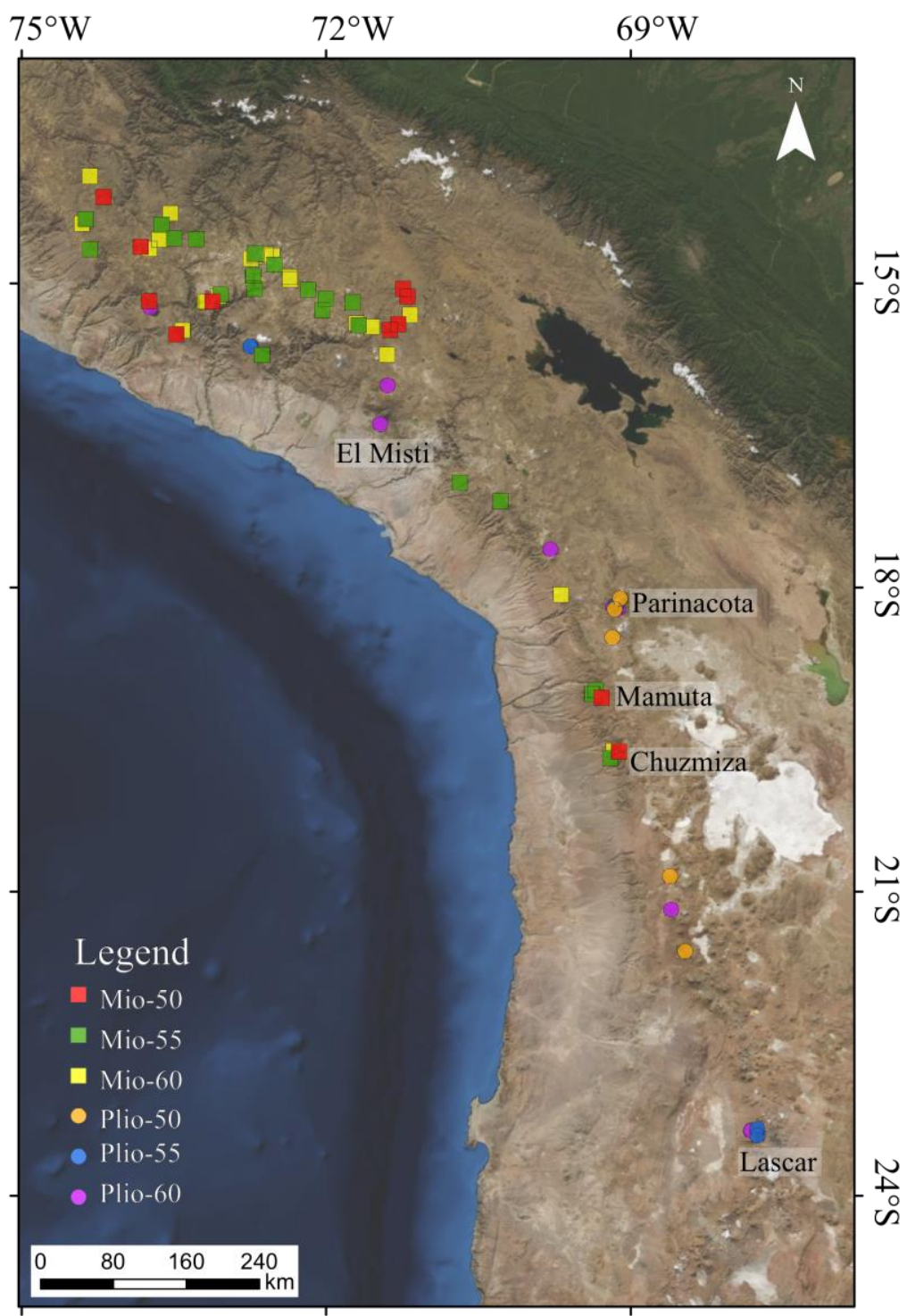

Fig. 6: Map of the Central Andes, indicating the geographic distribution of the sample locations. Source: Esri, DigitalGlobe, GeoEye, i-cubed, USDA, USGS, AEX, Getmapping, Aerogrid, IGN, IGP, swisstopo, and the GIS User Community.

\subsubsection{Single lava flow volume calculations}

Satellite images and profiles (Fig. 2, 4 and 5) show a significant difference between Miocene shields and Pliocene/Quaternary stratovolcanoes. However, when calculating the volume it is important to distinguish between effusion rate and eruption rate. Whereby (a) effusion rate is the volume flux of erupted lava that is feeding a flow at any particular point in time, and whereas (b) the eruption rate is the total volume of lava emplaced since the beginning of the eruption divided by the time since the eruption began. Thus effusion rate is the instantaneous lava flow output by a vent (high during the onset of eruption and then exponentially decreases towards the end), and eruption rate is the average lava output during a whole eruption, or as it is commonly used, during the lifetime of a 
Chapter 2 - Constraints on P-T conditions of crystallization and rates of magma formation before and after crustal thickening in the Central Andes

volcano. At the onset of a lava flow the waxing flow increases rapidly to a maximum effusion rate becoming thermally efficient, and defining its length.

Since in this study no direct observations or measurement of time laps of the lava flows are calculated, it is therefore important to look at the eruption rates of individual lava flows (in volumes) as a rough estimate for the effusion rate using the assumption longer and more voluminous lava flow had higher effusion rates and that single lava flows are one event. Total volume calculations of shield - statovolcanoes and their eruption rates are given in chapter 3.

I estimated the volumes of 120 lava flows of different lava-shields and stratovolcanoes of Miocene and Pliocene/Quaternary age within three different areas (see Fig. 5). Simple volume calculations were carried out using Google Earth. For each lava flow a polygon was carefully drawn for area calculations, an average thickness was then estimated. Despite most lava flows being well exposed, it is difficult to make accurate estimates of the volumes for multiple reasons: First, the bases of the lava flows are often not well exposed, making it sometimes challenging to estimate their total thickness. Second, flows often show multiple overlying lobes, making it difficult to determine the thickness of a particular flow event. Third, the thickness of a lava flow varies during its course.

In spite of these difficulties, average thicknesses were found by approximating the thickness at different locations of the low and interpolating. Base-elevations were determined by using geological maps and plotting profiles through the lava flow, hereby averaging elevation values at bends in the slope. The top elevations were estimated using geological maps and Google Earth elevations.

\subsubsection{Major and trace elements}

In this study 51 new samples of basaltic to rhyolitic compositions from Southern Peru were analyzed for major and trace elements by X-ray fluorescence analysis (XRF) on a PANalytical AXIOS Advanced sequential X-ray spectrometer. For XRF $2.8 \mathrm{~g}$ of powdered sample were thoroughly mixed with $5.6 \mathrm{~g}$ Spectroflux A12 (66 \% Dilithiumtetraborate $\mathrm{Li}_{2} \mathrm{~B}_{4} \mathrm{O}_{7}$ and $34 \%$ lithiummetaborate) and 0.64 $\mathrm{g}$ of $\mathrm{LiF}$ and was melted to glass tablet by an automatic fusion device. The analytical precision is better than 1-2\% and detection limits vary from 3 to $0.5 \mathrm{ppm}$ for the measured elements.

Trace element and rare earth elements (REE) concentrations were determined using FISONS VG PQ STE ICP-MS with a VG UV Microprobe laser system (266 nm). $100 \mathrm{mg}$ of powdered sample was dissolved under pressure in a mixture of $3 \mathrm{ml} \mathrm{HClO}_{4}$ using DAS30 system of Pico Trace GmbH also at the Geowissenschaftliche Zentrum of the University of Göttingen.

\subsubsection{Thermometry}

All the methods mentioned below assume that mixing between mafic and felsic magmas resulted in formation of a perfectly mixed magma without crystals and thus give mostly information about the final stage of crystallization. I estimate crystallization temperatures for 48 samples representing different ages (Miocene to Quaternary), petrography, compositions and volcanic styles 
Chapter 2 - Constraints on P-T conditions of crystallization and rates of magma formation before and after crustal thickening in the Central Andes

(see above). For comparison I have also analyzed one considerably older sample (APT-11) of Late Jurassic (133.1 Ma) age. Apt-11 is a glassy sample from the rind of a pillow basalt formed in a submarine setting. Mineral (Plagioclase, olivine, ortho- clinopyroxene, amphibole and oxides) compositions were obtained using a wavelength dispersive (WDS) detector on the JEOL JXA 8900 electron microprobe, at the Geowissenschaftliche Zentrum of the University of Göttingen. Olivine, ortho- and clinopyroxenes, plagioclase, amphibole, and oxides were all measured using appropriate calibration programs. Olivine, ortho- clinopyroxene, plagioclase and amphibole were analyzed at 15 $\mathrm{kV}$ accelerating voltage, $15 \mathrm{nA}$ probe current and beam size of $10 \mu \mathrm{m}$. The oxides on the other hand were analyzed at $20 \mathrm{kV}$ accelerating voltage, $20 \mathrm{nA}$ probe current and beam size of $5 \mu \mathrm{m}$. Table measured elements for the minerals can be found in appendix 1.

To acquire representative crystallization temperatures set of multiple thermometric calculations were considered (see detailed description below): (1) Fe-Ti-Oxides (Ghiorso and Evans, 2008) including the equilibrium test of Bacon and Hirschmann, (1988), (2) amphibole-plagioclase (Holland and Blundy, 1994), (3) Two pyroxene (Putirka et al., 2008), (4) Clino-pyroxene-liquid thermometry (Putirka et al., 2003), (5) Ortho-pyroxene-liquid thermometry (Putirka et al., 2008), (6) Olivine-liquid thermometry (Putirka et al., 2007) and (7) olivine-augite geothermometer (Loucks, 1996).

(1), The exchange of $\mathrm{Fe}^{2+} \mathrm{Ti}^{4+}-2 \mathrm{Fe}^{3+}$ between ilmenite and titanomagnetite, modelled by Ghiorso and Evans (2008) is currently the most accurate oxide thermometer, but it is also important to note that oxides are also most sensitive to post crystallization diffusion. Oxides are temperature and compositional dependent long range cation ordering associated with the symmetry breaking phase transition. At elevated temperature, the idealized structure of rhombohedral oxide solid solution, where interfaces between hcp oxygen anions are occupied by randomly distributed cations $\left(\mathrm{Fe}^{3+}, \mathrm{Fe}^{2+}\right.$, $\mathrm{Ti}^{4+}$ ). This configuration relate to the octahedral interstices on alternating layers. At low temperatures, the $\mathrm{Fe}^{2+}$ and $\mathrm{Ti}^{4+}$ cations form an ordered arrangement over these layers, and destroys the two-fold axes of symmetry and lowers the configurational entropy of solution. Together, the cation and magnetic ordering phenomena induce phase separation resulting in partitioning between disordered and partial ordered structures. Consequently, there are extensive miscibility gaps present in the series. At high temperatures or at oxygen fugacities $\mathrm{Y} \mathrm{NNO}+1$ results in an uncertainty of at least $50{ }^{\circ} \mathrm{C}$.

Using the method of Bacon and Hirschmann (1988) it's possible to determine whether the two oxides are in equilibrium or not. $\mathrm{Mg} / \mathrm{Mn}$ partitioning can indicate which phases may represent equilibrium pairs or whether analyses of exsolved phases reflect equilibrium with silicate liquid.

(2) The amphibole-plagioclase (Holland and Blundy, 1994) thermometer is based on exchange of albite and anorthite $(\mathrm{NaSi})(\mathrm{CaAl})_{-1}$ and edenite-richterite $(\mathrm{NaSi})_{-1}(\mathrm{CaAl})$ components. Dependent on the presence of quartz two different equations are given and the thermometer can also be applied on silica-undersaturated rocks. The two thermometers take into account non-ideal mixing in both 
Chapter 2 - Constraints on P-T conditions of crystallization and rates of magma formation before and after crustal thickening in the Central Andes

amphibole and plagioclase and are calibrated against an extensive dataset of both natural and synthetic amphiboles and has uncertainties of $35-40^{\circ} \mathrm{C}$.

(3) Two pyroxene (Putirka et al., 2008). To examine phase relations of the two pyroxenes the Fo-SiO ${ }_{2}$ system, En-Diopside system or the breakdown of jadeite can be used in geothermometry and estimates of equilibration temperatures. The main two pyroxene thermometer is from Lindsey (1983) and Purtirka et al., 2008 using composition of the 2 pyroxenes isotherms plotted in En-Fs-Wo space and is based on the $\mathrm{Ca}$ content which decreases with increasing temperatures. The temperature estimated error is $60{ }^{\circ} \mathrm{C}$.

(4) The clinopyroxene thermobarometer was developed by Putirka et al. (2003) and uses the compositions of clinopyroxenes and coexisting liquid to determine the temperature (error of $26{ }^{\circ} \mathrm{C}$ ) at which these two phases were last in equilibrium. Since the volume changes of jadite and calclium.tschermak into diopside hedenbergite are significant smaller and both the exchange equilibria are temperature dependent jadite and calclium.tschermak into diopside hedenbergite can be used as thermometers. The exchange equilibria are less sensitive to pressure. The thermodynamic basis and thermodynamic properties can be calculated from coefficients of the expressions. For a further thermodynamic approach see Putirka et al., 1996, 2003.

(5) Ortho-pyroxene-liquid thermometry (Putirka et al., 2008). The algorithm used to calculate orthopyroxene is based on a normative scheme similar to that use for clinopyroxene. Here all liquid components are based on cation fractions and all orthopyroxene on the numbers of cations calculated on a 6 oxygen basis.

(6) Olivine-liquid thermometry (Putirka et al., 2007) The temperature calculation from olivineliquid equilibria uses $\mathrm{Mg}$ and $\mathrm{Fe}^{2+}$ partitioning between coexisting olivine and glass (error $27^{\circ} \mathrm{C}$ ). To obtain the estimate temperatures the following is required 1) the $\mathrm{FeO}^{\text {liq }}$ of mantle equilibrated liquids or a $\mathrm{FeO}-\mathrm{MgO}$ trend line along which liquids are olivine saturated, 2) the $\mathrm{Fo}_{\max }$ of olivines that equilibrate with parental liquid compositions, 3) the value for the $\mathrm{Fe}-\mathrm{Mg}$ exchange coefficient between olivine and liquid, $\mathrm{K}_{\mathrm{D}}(\mathrm{Fe}-\mathrm{Mg})^{\text {ol-liq }}$, and estimates of 4$)$ the pressure $(\mathrm{P})$ of olivine-liquid equilibration, and 5) $f \mathrm{O}_{2}$ conditions) (Putirka et al., 2007). Temperature can be calculated from these five variables alone, and if the composition independent thermometers of Putirka (2005) are applied. For more precise temperature estimates $\mathrm{MgO}^{\mathrm{liq}}$ for parental liquids (using $\mathrm{FeO}^{\mathrm{liq}}, \mathrm{K}_{\mathrm{D}}(\mathrm{Fe}-\mathrm{Mg})^{\text {ol-liq }}$ and $\mathrm{Fo}_{\text {max }}$ as input); and then reconstruct the $\mathrm{SiO}_{2}{ }^{\text {liq }}$ and $\mathrm{Na}_{2} \mathrm{O}^{\text {liq }}+\mathrm{K}_{2} \mathrm{O}^{\text {liq }}$ for parental liquids as input into geothermometers. See for further thermodynamic basis Putirka et al., 2007.

(7) olivine-augite geothermometer (Loucks, 1996). The problem with all the above methods (besides the two pyroxene) is that most samples lack fresh glass. Taking the bulk rock would be a solution, but creates a bigger error as well. An olivine-augite geothermometer might overcome these deficiencies (Loucks, 1996) and has a standard error of only $6{ }^{\circ} \mathrm{C}$. The geothermometer uses $\mathrm{Mg}$ and $\mathrm{Fe}^{2+}$ partitioning between coexisting olivine and augite $\left[\mathrm{K}_{\mathrm{d}}=(\mathrm{Fe} / \mathrm{Mg})_{\mathrm{o}} /(\mathrm{Fe} / \mathrm{Mg})_{\mathrm{cpx}}\right]$ being a simple function of temperature. 
Chapter 2 - Constraints on P-T conditions of crystallization and rates of magma formation before and after crustal thickening in the Central Andes

Liquid composition were obtained by both mass balance calculations and modeled by MELTS. Mass balance calculations were done by subtracting the mineral composition, measured with EMPA, from the bulk rock which were measured with XRF. Another possibility would be measuring glass composition using the electron microprobe and use this as the liquid composition. However, the glass composition is the residue of final stage of crystallization that is thus different in composition as the liquid at the time of olivine, cpx and opx crystallization.

\subsubsection{MELTS}

MELTS is a software package aimed to facilitate thermodynamic modeling of phase equilibria in magmatic systems and is established upon the work of Ghiorso and Sack (1995) and Asimow and Ghiorso (1998). It provides the ability to compute equilibrium phase relations for igneous systems over the temperature range $500-2000{ }^{\circ} \mathrm{C}$ (can be overestimated as much as approximately $40{ }^{\circ} \mathrm{C}$ ) and the pressure range 0-20 kbar. Differentiation for magmatic processes can be modeled with MELTS as a series of steps in temperature and pressure, temperature and volume, enthalpy and pressure or entropy and pressure (more on this in chapter 3). The main problem with MELTS is that the program is better calibrated in mafic systems and alkalic mafic magmas rather than andesitic compositions. Especially phase equilibria involving hornblende and biotite are challenging to model and consequently simulating the evolution of intermediate to silica-rich calc-alkaline systems as well.

To gain the best results, pressure and water contents in the rhyolite-MELTS model (Gulda et al., 2012) were varied to best-fit natural samples, meaning to thermometry (see above) and hygrometry data (see below). Besides, MELTS results were matched to the corresponding measured EMPA mineral composition and their calculated crystallization temperatures (see above and Fig. 7). A consistent dataset is thus provided, however this might not be necessary the only possible solution.

Water contents derived from MELTS were compared to the Plagioclase-liquid hygrometer (Lange et al., 2009). Changes in dissolved $\mathrm{H}_{2} \mathrm{O}$ drive significant variations in the composition of crystallization plagioclase. Water reduces the activity of $\mathrm{Na}_{2} \mathrm{O}$ relatively to $\mathrm{CaO}$ which would lead to the crystallization of more anorthite rich plagioclase. Also is there is a preferential formation of $\mathrm{Si}-\mathrm{OH}$ bonds versus $\mathrm{Al}-\mathrm{OH}$ bonds in magmatic liquids, the activity of $\mathrm{NaAlSi}_{3} \mathrm{O}_{8}$ will be even more reduced. See Lange et al., 2009 for the equations. 

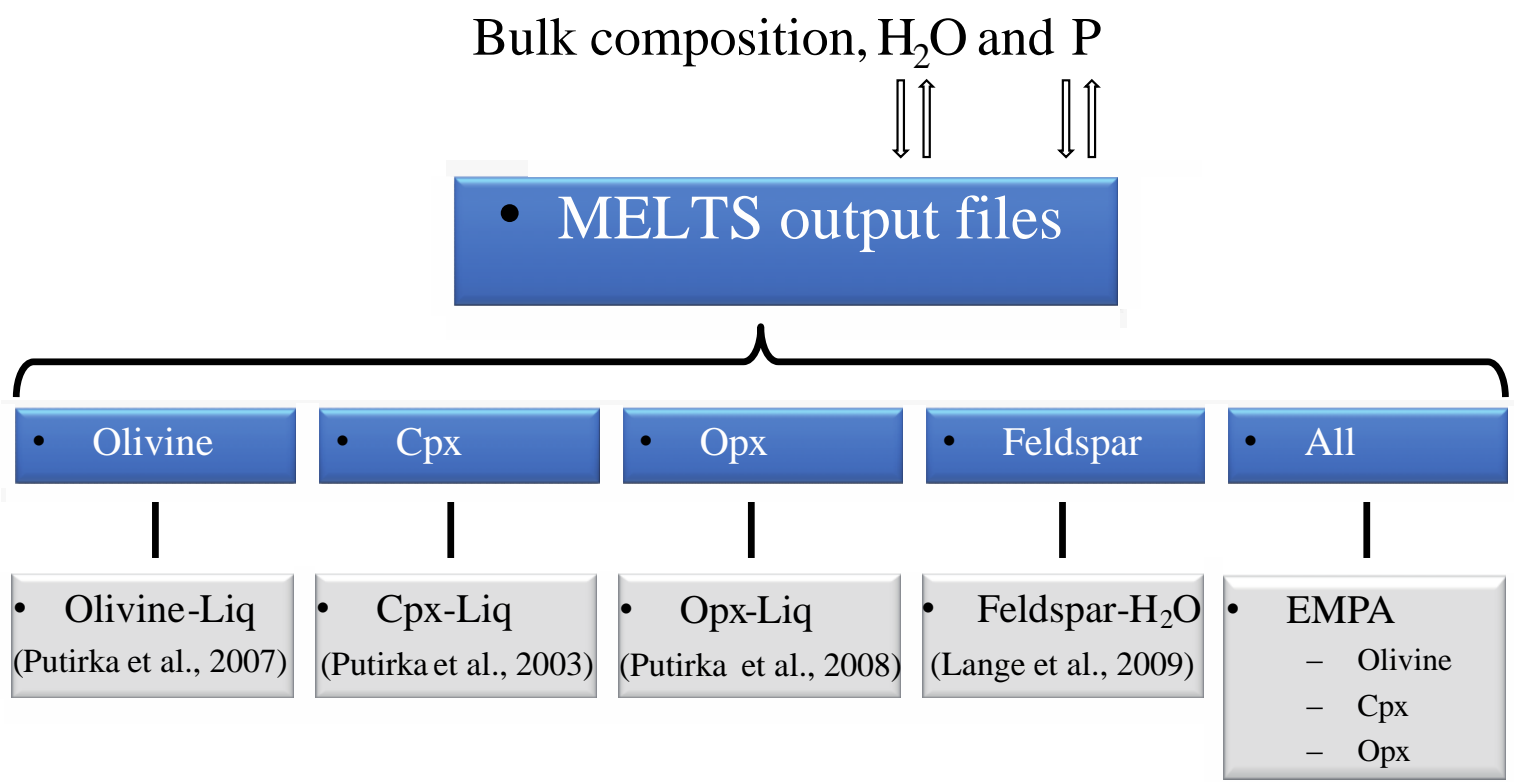

Fig. 7: Schematic of MELTS calculations (Gualda et al., 2012). To acquire the best results, pressure and water contents input parameters) were varied until a best fit with thermometry data and EMPA mineral measurements was obtained. MELTS results (blue boxes) were matched to the calculated crystallization temperatures using multiple thermodynamic models (grey boxes). MELTS results were also compared with measured mineral compositions.

\subsubsection{Arc Basalt Simulator (ABS)}

The ABS4 (Arc Basalt Simulator) was used to simulate high Mg\# basalt geochemistry and P-T conditions in relatively cold subduction zones (Kimura et al., 2014). ABS4 is a geochemical mass balance model for arc magma genesis including calculations of slab dehydration/melting and fluid/melt-fluxed melting of peridotite using thermodynamically and experimentally petrogenetic grids for prograde metamorphism and melting of the slab, and fluid/melt-fluxed melting of peridotite in the mantle wedge (Kimura et al., 2010)

ABS4 is a forward model that calculates a primary magma composition from slab and mantle petrological parameters. The user can vary these parameters and the resulting calculated magma composition compared to a target magma that is based on observations. Incompatible trace element, $\mathrm{Sr}-\mathrm{Nd}-\mathrm{Hf}-\mathrm{Pb}$ isotope, and major element compositions are used in the comparison. Sedimentary compositions were used after Plank (2007) and Syracruse (2010). A Monte Carlo calculation is used to make a quantitative comparison in order to avoid artificial correlations between the parameters. Successful results are those in which calculated and observed compositions agree to within userdefined limits.

Furthermore the element behavior during slab dehydration is formulated at $\mathrm{P}$ and $\mathrm{T}$ conditions, on the basis of modeled slab surface P-T trajectories and prograde metamorphism. Using both mafic samples from fore- and back-arc the depth of the source and storage (reservoir depth) was modeled. To acquire high $\mathrm{Mg \#}$ olivine was added to the samples after mass balance for the most mafic sample 
Chapter 2 - Constraints on P-T conditions of crystallization and rates of magma formation before and after crustal thickening in the Central Andes

(BAR-00-20). The element behavior during slab dehydration is formulated at $\mathrm{P}$ and $\mathrm{T}$ on the basis of modeled slab surface PT trajectories.

\subsubsection{Barometry}

Other applied barometry methods were the Al in hornblende method of (Schmidt, 1992; Ridolfi and Renzulli, 2012) and the 2 pyroxene barometer of Putirka (2008). The Al-in-hornblende barometer uses equilibrium of the assemblage hornblende, biotite plagioclase, orthoclase, quartz and oxides and is dependent on bulk composition. The total $\mathrm{Al}$ content of hornblende in atoms per formula unit increase with pressure and temperature can be ascribed mainly to a tschermak exchange accompanied by minor plagioclase substitution. With a precision of $0.6 \mathrm{kbar}$ this barometer might be quiet accurate however it is calibrated for more dacitic compositions rather than andesites and thus the precision must be treated with care.

Ridolfi and Renzulli (2012) present five different barometric equations by using only the amphibole compositions and thus more suitable for andesitic compositions. Equations $1 \mathrm{~b}$ and $1 \mathrm{c}$ are calibrated for low pressure ( 130-500 MPa) and have low average standard and maximum errors of 37 and $43 \mathrm{MPa}$ and 69 and $116 \mathrm{MPa}$, respectively. In contrast, equations 1a, 1d, and 1e are calibrated for 130 to $82200 \mathrm{MPa}, 400$ to $1500 \mathrm{MPa}$, and 930 to $2200 \mathrm{MPa}$, and they have higher average standard and maximum errors of $\sim 141$ to $175 \mathrm{MPa}$ and 377 to $540 \mathrm{MPa}$. All equations are reliable under a certain pressure range with an overall statistic uncertainty of $11.5 \%$ on the pressure. Before the application of the 5 different equations it is necessary to calculate the amphibole formula using the 13cation method (Leake et al., 1997). Crystallization pressures of clino and orthopyroxene pairs were calculated by applying Putirka (2008). Pressure estimations have a standard error of $3.2 \mathrm{kbar}$. By comparing observed and experimentally determined $\mathrm{Fe}-\mathrm{Mg}$ exchange coefficients equilibrium conditions between cpx and opx were tested.

\subsubsection{Crystal Size Distribution (CSD)}

CSD is a quantitative textural measurement, where the number of crystals of a mineral per unit volume with a series of defined size intervals and can provide information of fundamental petrographical parameters and processes, such as crystal growth rate and magma mixing. Representative CSD's were determined on three to four samples for five different groups (see Table 1, below). The samples were selected according to abundance of fresh and euhedral plagioclase crystals. Thin sections were scanned using a Nikon Coolscan 4000ED with a resolution of 4000 dpi both under normal light and crossed polarizers. The images were then transferred to adobe Illustrator and Photoshop to create a binary image. Using the binary image plagioclase crystals could be quantified using the program ImageJ, which calculates dimensions of a best-fit ellipse to the crystal outlines and its orientation and position. 
The program CSDCorrections Higgins, 2000 was developed to transform two dimensional data from ImageJ to three dimensional crystal size distributions by incorporating corrections for the probability effect and cut-section effect. CSDCorrections version 1.4 was used in this study to convert 2D measurements of the long axis of the best-fitting ellipse to 3D crystal size distributions. Based on visual inspection of the samples, a roundness factor of 0.2 was chosen, and when needed, a correction was made for vesicles or voids. Based on morphology and size, several plagioclase crystals of each sample were measured by the electron microprobe JEOL JXA 8900 at key locations along rim-core profiles to support the CSD results and assess the possibility of multiple stages of magma. Equilibrium melt compositions were calculated from trace and minor element compositions of plagioclase growth zones according to the method of Bindeman et al. (1988).

Table 1: Estimated total mineral abundance and the plagioclase for used CSD samples.

\begin{tabular}{llcc}
\hline Group & Sample & Total abundance (\%) & Plagioclase abundance (\%) \\
\hline Mio-50 & MAM-24 & 9 & 4 \\
& MIO-12-39 & 32 & 20 \\
& MIO-12-41 & 8 & 5 \\
Mio-55 & MAM-11-3 & 10 & 7 \\
& MAM-14 & 10 & 8 \\
& MIO-12-40 & 8 & 6 \\
& BAR-00-28 & 10 & 6 \\
Mio-60 & YAH-00-16 & 5 & 4 \\
& BAR-01-83 & 10 & 6 \\
& MIO-12-01 & 25 & 23 \\
Plio-55 & BAR-00-33 & 7 & 4 \\
& LAS-07-05 & 7 & 5 \\
& PAR-03-38 & 7 & 4 \\
Plio-60 & LAR-07-05 & 10 & 8 \\
& MIS-99-04 & 15 & 8 \\
& BAR-00-19 & 8 & 4 \\
& BAR-00-31 & 15 & 13
\end{tabular}

\subsection{Results}

In order to get a better understanding of the above mentioned mantle wedge processes, petrology, chemistry, temperature, pressure, $\mathrm{H}_{2} \mathrm{O}$, density, viscosity, $f \mathrm{O}_{2}$ and volumes that may have a primary control on flow types were determined by a range of geothermometers, hygrometers, barometers and thermodynamic models on olivines, ortho-, clinopyroxenes, plagioclase, amphiboles and oxides. Plagioclase crystal size distribution (CSD) and compositions were analyzed in order to grasp the degree to which magma mixing processes between end-members influence the above mentioned parameters.

\subsubsection{Petrography}

Table 2 summarizes some of the main petrographic observations of each group. All samples are commonly porhyritic and pilotaxitic with generally small phenocrysts of plagioclase, clino- and orthopyroxene. Olivine occurs only within the more mafic samples and amphibole within the felsic 
Chapter 2 - Constraints on P-T conditions of crystallization and rates of magma formation before and after crustal thickening in the Central Andes

samples. Amphiboles are generally rare in Miocene group lavas and are mostly altered, with thick (up to $0.5 \mathrm{~mm}$ ) reaction rims, which show the melt surrounding the amphiboles was not in equilibrium with them when it was erupted. The thick rim is likely an anhydrous reaction due to decompression (Browne and Gardner, 2006; Devine et al., 1998; Rutherford and Hill, 1993). For most amphibole containing of Miocene samples only a few phenocrysts are present. However towards the dacitic samples (Mio-60), when present, amphibole abundances are much higher (up to $9 \%$ ). Furthermore amphibole is common within the Pliocene groups; generally the phenocrysts are subhedral and up to $0.5 \mathrm{~mm}$ in length. Most of them have no or only small reaction rims. The difference of amphiboles abundances between the Miocene and Pliocene/Quaternary samples is also clear when comparing the presence of amphibole in a certain sample. All samples of the Plio-60 group contains amphiboles (in various amount of abundances) while within the Mio-60 group only $60 \%$ of the samples contains amphibole, with half of the samples containing amphiboles as traces.

Quartz occurs in only three samples of the Mio-60 group and is very rare. The same holds for biotites, which occur in a few samples in low abundances and are extremely altered. Phenocryst abundances are slightly higher (by a few percent) within the Miocene groups. Additionally, the Pliocene samples show lower variability in phenocryst sizes and seem generally more coarse-grained (fewer phenocrysts smaller as $0.5 \mathrm{~mm}$ ). Minimal variation in mineral chemistry is found within the groups. For petrographic photos see appendix omit.

Table 2: Miocene and Pliocene lavas are characterized by surprisingly homogenous mineralogy comprising plagioclase, clino- and orthopyroxene and/or olivine and/or amphibole. Small variations between the Miocene and Pliocene groups can be seen the lower total abundances, and the presence of olivine and amphibole.

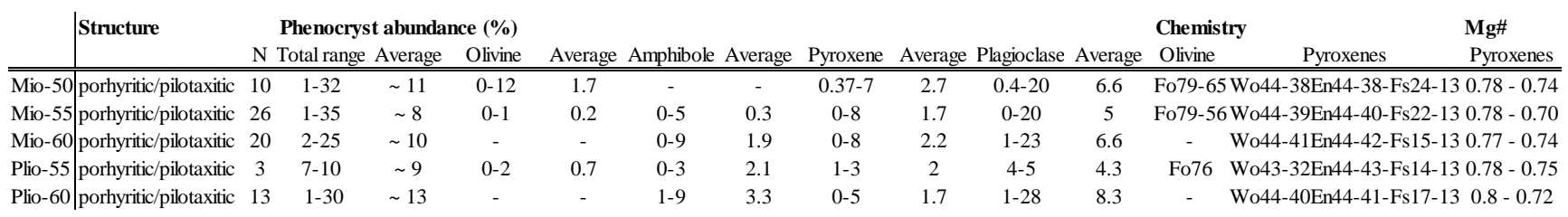

\subsubsection{Geochemistry}

The overall compositional variation of erupted magmas in the Central Andes over the past $30 \mathrm{Ma}$ is trimodal (ranging from $45 \mathrm{wt} \%$ to $77 \mathrm{wt} \% \mathrm{SiO}_{2}$, Fig. 8 and 10) based on 2181 samples. Furthermore, the rocks define a typical calc-alkaline trend as indicated on the standard AFM diagram (Fig. 9). The $\mathrm{Mg \#}$ remains varies from 0.63 for the most mafic sample to 0.33 for dacitic samples. Major, trace and REE analyses of Miocene and Pliocene - Quaternary selected samples from southern Peru and northern Chile are given in Table 3 and 4. However, the majority of lava flows are remarkably restricted in composition with $80 \%$ having $\mathrm{SiO}_{2}$ contents between 56 and 66 wt\% (Fig.10) - true basalts are exceedingly rare. 


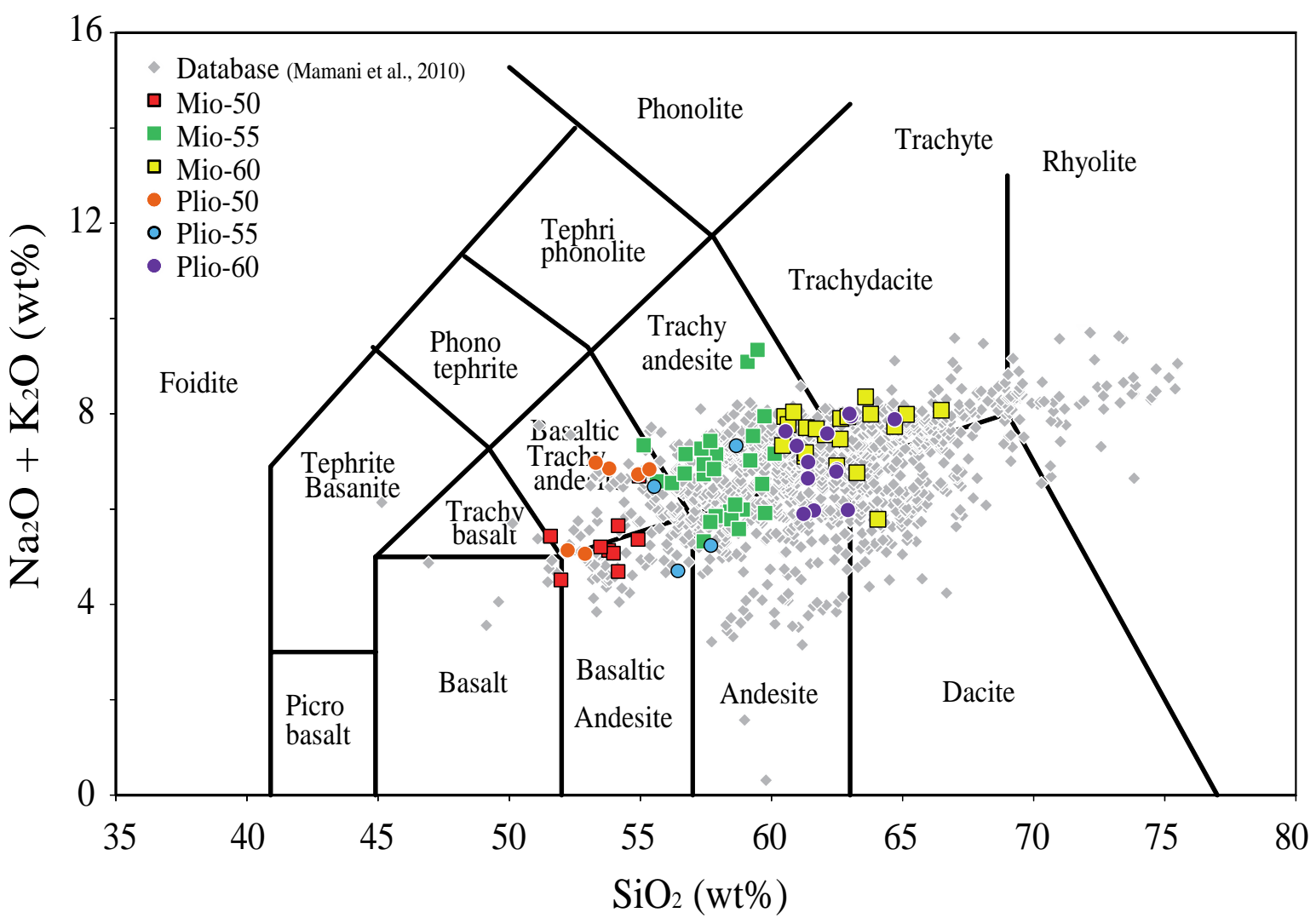

Fig. 8: TAS diagram after Le Bas et al., (1986) showing the predominantly andesitic characteristics of the studied lava samples. Reference samples for the Central Andes (Mamani et al., 2008)

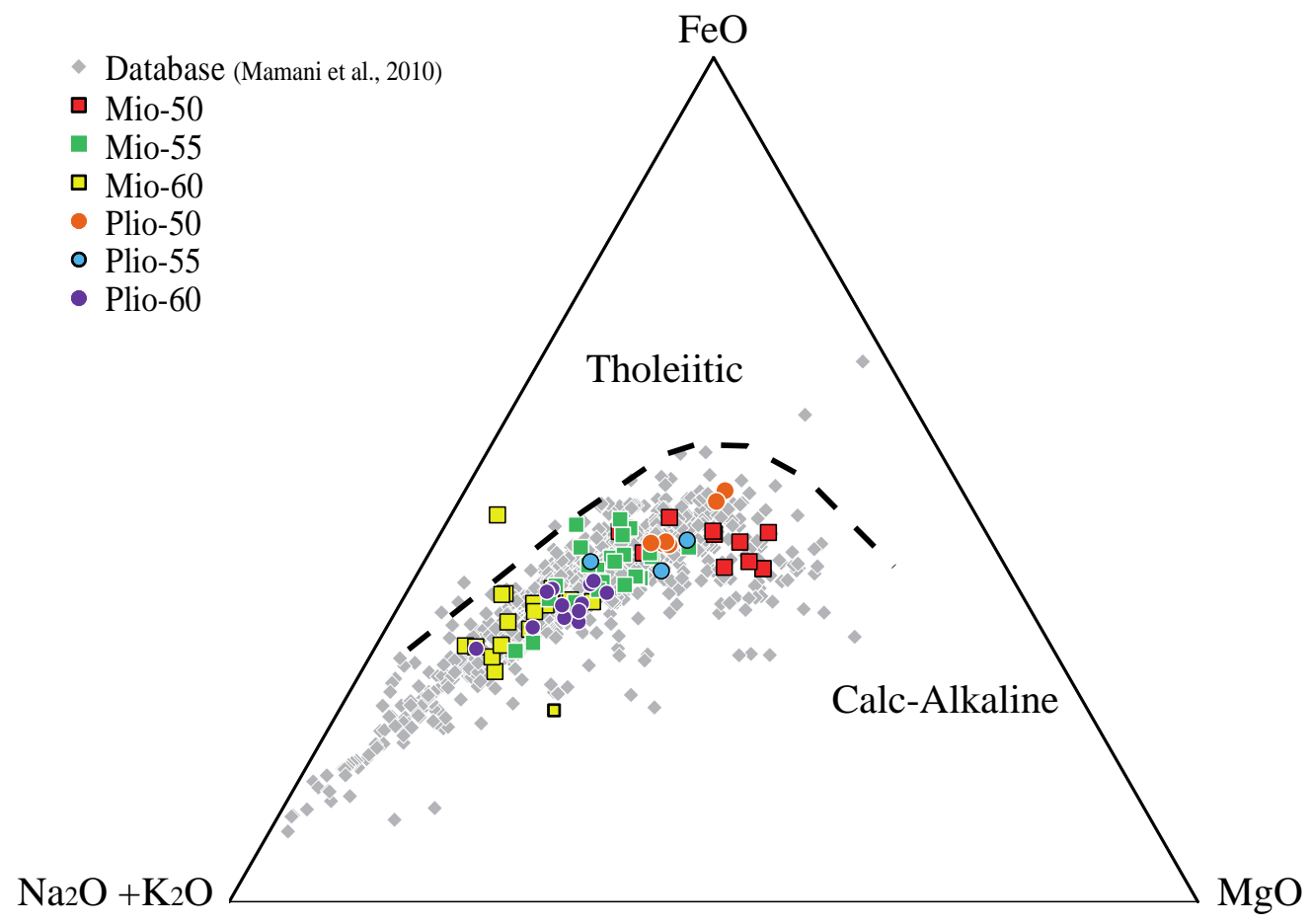

Fig. 9: Calc-alkaline series of all analyzed samples projected on an AFM diagram 
Chapter 2 - Constraints on P-T conditions of crystallization and rates of magma formation before and after crustal thickening in the Central Andes

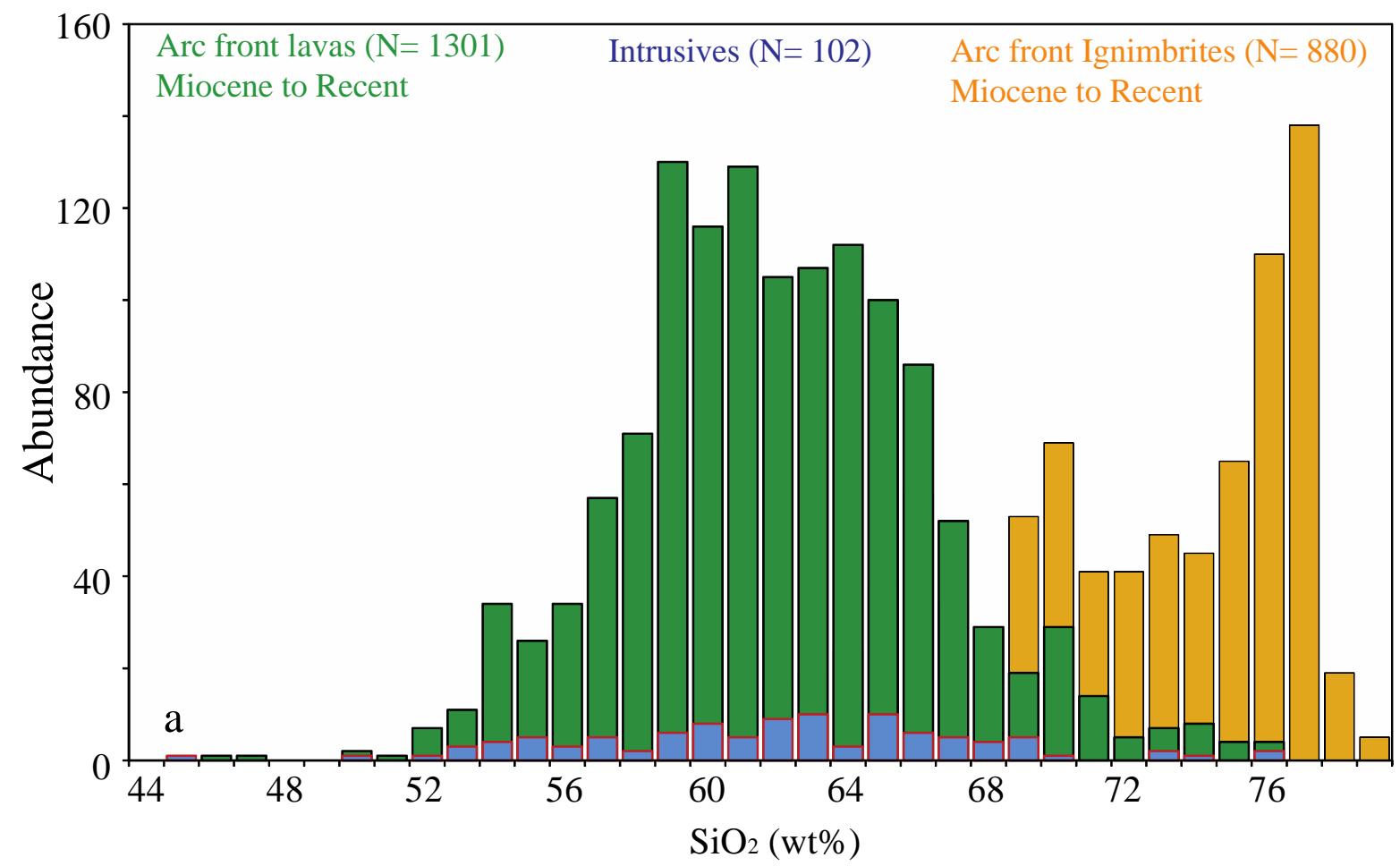

Miocene

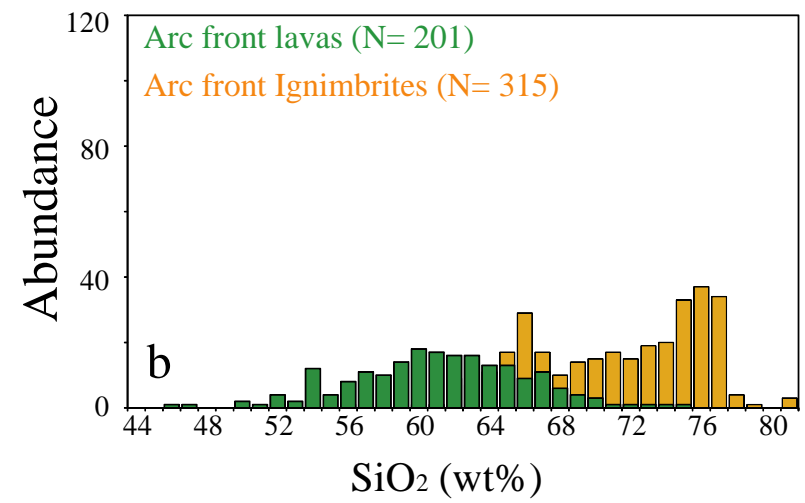

Pliocene-Quaternary

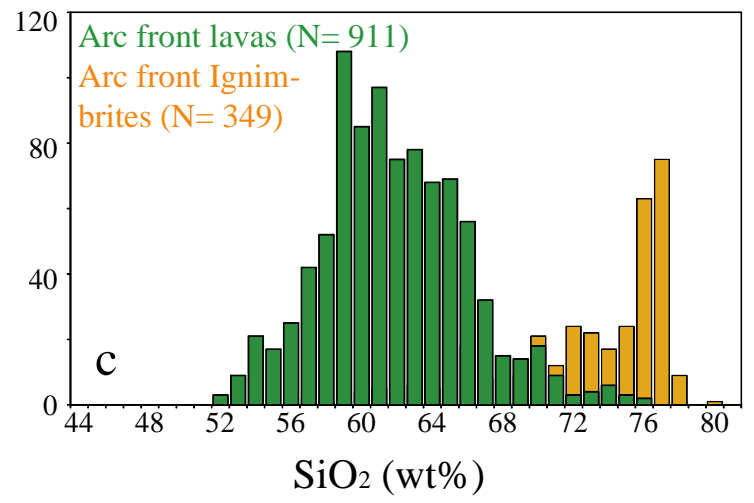

Fig. 10: Frequency distributions of all database samples for $\mathrm{SiO}_{2}$. 
Chapter 2 - Constraints on P-T conditions of crystallization and rates of magma formation before and after crustal thickening in the Central Andes

Table 3: Major, trace and REE analyses of Miocene selected samples from southern Peru and northern Chile

\begin{tabular}{|c|c|c|c|c|c|c|c|c|c|c|c|c|c|c|c|c|c|c|c|}
\hline & BAR-01-80 1 & BAR-00-20 1 & ${ }^{1}$ BAR-01-8 $87^{1}$ & MIO-12-39 & MIO-12-41 & MAM-24 & BAR-01-85 & BAR-01-81 ${ }^{1}$ & ${\text { CUM }-07^{1}}^{1}$ & MIO-12-25 & BAR-00-22 ${ }^{1}$ & OIS-12 01 & MIO-12-06 & MIO-12-07 & MIO-12-02 & MIO-12-16 & MIO-12-23 & ARE-12 10 & MIO-12-51 \\
\hline$\overline{\text { Group }}$ & Mio-50 & Mio-50 & Mio-50 & Mio-50 & Mio-50 & Mio-50 & Mio-50 & Mio-50 & Mio-50 & Mio-50 & Mio-50 & Mio-50 & Mio-55 & Mio-55 & Mio-55 & Mio-55 & Mio-55 & Mio-55 & Mio-55 \\
\hline Latitude & -71.239 & -73.744 & -71.369 & -73.477 & -14.638 & -69.285 & -71.288 & -71.199 & -69.121 & -73.112 & $\begin{array}{l}-74.329 \\
\end{array}$ & -74.193 & -71.740 & -72.036 & -74.371 & -72.510 & -73.039 & -72.167 & -72.176 \\
\hline Longitude & -15.051 & -15.171 & -15.455 & -15.498 & -73.830 & -19.086 & -15.397 & -15.127 & -19.617 & -15.175 & -14.658 & -14.144 & -15.187 & -15.262 & -14.360 & -14.812 & -15.104 & -15.052 & -15.060 \\
\hline $\mathrm{SiO}_{2}$ & 49.60 & 50.70 & 51.90 & 52.89 & 53.12 & 53.16 & 53.30 & 53.40 & 53.52 & 54.21 & 54.60 & 54.80 & 49.38 & 50.42 & 54.62 & 55.25 & 55.44 & 55.25 & 55.65 \\
\hline $\mathrm{TiO}_{2}$ & 0.97 & 1.23 & 1.04 & 1.09 & 1.30 & 0.98 & 1.52 & 1.00 & 1.21 & 1.41 & 0.72 & 1.17 & 0.84 & 0.80 & 0.69 & 1.07 & 1.33 & 1.33 & 1.36 \\
\hline $\mathrm{Al}_{2} \mathrm{O}_{3}$ & 15.10 & 16.60 & 16.10 & 17.96 & 17.99 & 17.35 & 16.00 & 17.00 & 18.18 & 17.29 & 16.00 & 17.19 & 13.77 & 14.10 & 16.67 & 17.67 & 16.36 & 16.14 & 16.29 \\
\hline $\mathrm{FeO}_{t}$ & 9.10 & 9.52 & 8.47 & 8.94 & 8.82 & 8.39 & 8.14 & 8.16 & 8.65 & 8.14 & 6.39 & 8.11 & 4.86 & 4.71 & 6.26 & 7.69 & 8.26 & 6.73 & 7.25 \\
\hline $\mathrm{MnO}$ & 0.15 & 0.13 & 0.14 & 0.14 & 0.12 & 0.14 & 0.13 & 0.14 & 0.11 & 0.12 & 0.08 & 0.12 & 0.07 & 0.07 & 0.10 & 0.10 & 0.11 & 0.09 & 0.10 \\
\hline $\mathrm{MgO}$ & 7.34 & 6.62 & 6.34 & 5.14 & 3.96 & 5.57 & 3.07 & 3.93 & 5.07 & 3.43 & 2.83 & 5.77 & 2.29 & 2.10 & 3.35 & 2.09 & 4.11 & 3.22 & 3.84 \\
\hline $\mathrm{CaO}$ & 9.26 & 9.09 & 8.10 & 8.20 & 7.81 & 8.57 & 7.65 & 7.46 & 7.95 & 6.71 & 5.79 & 7.85 & 4.81 & 4.71 & 6.26 & 6.23 & 6.95 & 5.98 & 6.71 \\
\hline $\mathrm{Na}_{2} \mathrm{O}$ & 2.19 & 3.07 & 3.26 & 3.98 & 3.90 & 3.14 & 3.81 & 3.46 & 3.64 & 4.53 & 3.20 & 4.02 & 4.82 & 4.86 & 4.01 & 3.90 & 4.20 & 4.53 & 4.70 \\
\hline $\mathrm{K}_{2} \mathrm{O}$ & 3.03 & 1.33 & 1.69 & 1.17 & 1.64 & 1.46 & 2.50 & 3.04 & 1.39 & 2.69 & 2.21 & 1.33 & 2.78 & 3.06 & 1.67 & 2.58 & 2.26 & 2.59 & 2.32 \\
\hline $\mathrm{P}_{2} \mathrm{O}_{5}$ & 0.34 & 0.22 & 0.29 & 0.29 & 0.31 & 0.24 & 0.52 & 0.40 & 0.30 & 0.63 & 0.19 & 0.25 & 0.46 & 0.44 & 0.19 & 0.41 & 0.44 & 0.63 & 0.62 \\
\hline total & 97.08 & 98.51 & 97.33 & 99.80 & 98.97 & 99.00 & 96.64 & 97.99 & 100.02 & 99.16 & 92.01 & 100.61 & 84.07 & 85.26 & 93.82 & 96.99 & 99.47 & 96.49 & 98.84 \\
\hline $\mathrm{Rb}$ & 123.9 & 40.9 & 58.5 & 20.8 & 49.9 & 26.9 & 73.4 & 115.9 & 39.9 & 79.3 & 109.6 & 37.3 & 108.0 & 110.0 & 57.7 & 102.0 & 75.4 & 67.5 & 54.1 \\
\hline $\mathrm{Sr}$ & 633 & 728 & 554 & 321 & 329 & 563 & 1,138 & 789 & 857 & 511 & 450 & 252 & 501 & 508 & 272 & 264 & 416 & 591 & 634 \\
\hline Y & 21.0 & 19.3 & 23.3 & 19.9 & 22.4 & 17.0 & 20.3 & 25.8 & 15.4 & 23.5 & 17.8 & 21.2 & 18.0 & 16.4 & 17.7 & 42.4 & 22.0 & 18.8 & 19.8 \\
\hline $\mathrm{Zr}$ & 115 & 105 & 152 & 154 & 193 & 110 & 284 & 170 & 127 & 150 & 179 & 165 & 146 & $\begin{array}{l}153 \\
153\end{array}$ & 168 & $\begin{array}{l}42.4 \\
265\end{array}$ & $\begin{array}{l}2.0 \\
207\end{array}$ & $\begin{array}{l}1.8 \\
129\end{array}$ & $\begin{array}{l}19.8 \\
269\end{array}$ \\
\hline $\mathrm{Nb}$ & 5.2 & 3.8 & 9.8 & 5.0 & 9.1 & 5.4 & 27.8 & 11.8 & 12.0 & 19.5 & 6.6 & 6.6 & $\begin{array}{l}140 \\
15.8\end{array}$ & $\begin{array}{l}153 \\
13.9\end{array}$ & $\begin{array}{l}100 \\
6.6\end{array}$ & 12.2 & 9.1 & 12.4 & 13.6 \\
\hline $\mathrm{Ta}$ & 0.3 & 0.4 & 0.6 & 0.25 & 0.52 & 0.3 & 1.2 & 0.7 & 0.7 & 0.96 & 0.6 & 0.39 & 0.87 & 0.71 & 0.41 & 0.75 & 0.49 & 0.56 & 0.64 \\
\hline $\mathrm{Ba}$ & 855 & 315 & 552 & 445 & 566 & 592 & 1,180 & 1,160 & 497 & 440 & 518 & 406 & 547 & 576 & 590 & 887 & 862 & 431 & 429 \\
\hline $\mathrm{Pb}$ & 11.4 & 4.5 & 9.0 & 5.1 & 7.3 & 6.5 & 10.1 & 13.2 & 6.7 & 11.0 & $\begin{array}{l}10.0 \\
\end{array}$ & $\begin{array}{l}0.00 \\
8.9\end{array}$ & 11.7 & 10.5 & 9.5 & 9.0 & 8.4 & 11.1 & 8.6 \\
\hline $\mathrm{Hf}$ & 3.3 & 3.0 & 4.0 & 3.63 & 4.57 & 2.9 & 7.2 & 4.7 & 3.5 & 7.12 & 4.8 & 3.91 & 7.11 & 7.41 & 3.82 & 6.08 & $\begin{array}{l}0.7 \\
4.97\end{array}$ & 6.52 & 6.11 \\
\hline Th & 5.1 & 4.9 & 6.0 & 1.82 & 4.85 & 2.3 & 8.8 & 6.7 & 1.8 & 7.30 & 17.1 & 2.95 & 9.36 & 16.40 & 4.68 & 12.00 & 8.14 & 6.89 & 5.76 \\
\hline $\mathrm{U}$ & 1.4 & 1.4 & 1.3 & 0.31 & 1.07 & 0.5 & 1.6 & 1.9 & 0.2 & 1.03 & 4.5 & 1.29 & 2.94 & 2.00 & 1.02 & 2.11 & 1.11 & 1.04 & 0.89 \\
\hline $\mathrm{Ni}$ & 62.4 & 85.6 & 117.7 & 42.9 & 20.8 & 46.4 & 65.0 & 19.1 & 65.3 & $\begin{array}{l}17.7\end{array}$ & 16.7 & 69.8 & 23.1 & 14.2 & 19.8 & 12.9 & 44.2 & 26.0 & 37.5 \\
\hline $\mathrm{La}$ & 18.2 & 13.0 & 23.3 & 19.2 & 29.7 & $\begin{array}{l}4.4 \\
15.2\end{array}$ & 59.7 & 26.8 & 18.9 & 67.7 & 20.7 & 25.8 & 80.3 & 88.5 & 25.2 & 47.1 & 43.4 & 73.8 & 79.1 \\
\hline $\mathrm{Ce}$ & 38.0 & 31.8 & 47.8 & 43.3 & 62.7 & 32.6 & 121.4 & 55.2 & 44.2 & 133.0 & 44.2 & 49.8 & 55.0 & 60.0 & 47.6 & 89.6 & 90.9 & 51.5 & 158.0 \\
\hline $\begin{array}{l}\text { Pr } \\
\text { nat }\end{array}$ & 4.90 & 4.63 & 5.88 & 5.34 & 7.38 & 4.31 & $\begin{array}{l}14.20 \\
\end{array}$ & 6.83 & 5.82 & $\begin{array}{l}14.60 \\
\end{array}$ & 5.59 & 6.12 & 15.60 & 16.60 & 5.55 & 10.40 & 10.40 & 16.00 & $\begin{array}{l}17.40 \\
\end{array}$ \\
\hline $\mathrm{Nd}$ & 21.3 & 21.1 & 24.3 & 22.7 & 29.7 & 18.2 & 54.0 & 28.2 & 26.2 & 53.9 & 21.9 & 25.2 & 54.2 & 56.3 & 21.2 & 40.0 & 40.8 & 58.2 & 64.4 \\
\hline $\mathrm{Sm}$ & 4.70 & 4.86 & 5.18 & 4.95 & 6.01 & $\begin{array}{l}3.76 \\
\end{array}$ & 9.01 & 5.98 & 5.36 & 8.94 & 4.40 & 5.20 & 8.14 & 8.12 & 4.02 & 7.77 & 7.51 & 8.95 & 10.20 \\
\hline Eu & 1.50 & 1.43 & 1.51 & 1.44 & 1.72 & 1.08 & 2.43 & 1.73 & 1.72 & 2.46 & 1.04 & 1.54 & 2.12 & 2.07 & 1.14 & 2.01 & 1.97 & 2.36 & 2.67 \\
\hline $\mathrm{Gd}$ & 4.60 & 4.46 & 5.12 & 4.15 & 5.10 & 3.38 & 7.87 & 5.74 & 4.99 & 6.94 & 3.96 & 4.37 & 6.28 & 6.15 & 3.44 & 6.93 & 5.87 & 6.77 & 7.39 \\
\hline $\mathrm{Tb}$ & 0.70 & 0.64 & 0.81 & 0.67 & 0.80 & 0.47 & 1.00 & 0.89 & 0.63 & 0.94 & 0.57 & 0.67 & 0.76 & 0.73 & 0.53 & 1.13 & 0.85 & 0.82 & 0.94 \\
\hline Dy & 4.10 & 3.83 & 4.67 & 3.73 & 4.31 & 2.79 & 4.62 & 5.14 & 3.25 & 4.53 & 3.48 & 3.50 & 3.41 & 3.11 & 2.95 & 6.54 & $\begin{array}{l}4.19 \\
\end{array}$ & 3.58 & 4.17 \\
\hline Но & 0.80 & 0.74 & 0.92 & 0.71 & 0.81 & 0.55 & 0.79 & 1.02 & 0.54 & 0.83 & 0.69 & 0.67 & 0.61 & 0.54 & 0.58 & 1.34 & 0.77 & 0.63 & 0.72 \\
\hline $\mathrm{Er}$ & 2.40 & 2.03 & 2.67 & 1.96 & 2.15 & 1.44 & 2.22 & 3.02 & 1.40 & 2.24 & 1.98 & 1.78 & 1.67 & 1.49 & 1.64 & 3.84 & 2.05 & $\begin{array}{l}1.69\end{array}$ & 1.92 \\
\hline $\mathrm{Tm}$ & $\begin{array}{l}0.40 \\
0.30\end{array}$ & 0.27 & 0.36 & 0.26 & 0.28 & $\begin{array}{l}1.44 \\
0.20\end{array}$ & 0.26 & $\begin{array}{l}0.02 \\
0.41\end{array}$ & $\begin{array}{l}0.40 \\
0.17\end{array}$ & 0.29 & $\begin{array}{l}1.90 \\
0.27\end{array}$ & 0.24 & 0.21 & $\begin{array}{l}1.49 \\
0.19\end{array}$ & $\begin{array}{l}0.04 \\
0.22\end{array}$ & $\begin{array}{l}.04 \\
0.54\end{array}$ & 0.26 & $\begin{array}{l}0.09 \\
0.03\end{array}$ & 0.24 \\
\hline $\mathrm{Yb}$ & 2.10 & $\begin{array}{l}1.73 \\
\end{array}$ & 2.36 & $\begin{array}{l}0.20 \\
\end{array}$ & $\begin{array}{l}0.20 \\
\end{array}$ & $\begin{array}{l}.20 \\
.33\end{array}$ & $\begin{array}{l}0.20 \\
1.59\end{array}$ & 2.71 & 1.11 & 1.84 & 1.85 & 1.59 & 1.44 & 1.26 & 1.55 & 3.72 & $\begin{array}{l}.20 \\
1.75\end{array}$ & $\begin{array}{l}0.20 \\
\end{array}$ & $\begin{array}{l}0.24 \\
.54\end{array}$ \\
\hline $\begin{array}{l}10 \\
\mathrm{Lu}\end{array}$ & 0.30 & 0.25 & 0.37 & 0.25 & $\begin{array}{l}1.91 \\
0.26\end{array}$ & $\begin{array}{l}1.53 \\
0.20\end{array}$ & 0.24 & 0.43 & 0.17 & $\begin{array}{l}1.04 \\
0.26\end{array}$ & $\begin{array}{l}1.03 \\
0.28\end{array}$ & 0.22 & $\begin{array}{l}1.44 \\
0.20\end{array}$ & $\begin{array}{l}1.20 \\
0.17\end{array}$ & 0.22 & 0.54 & 0.24 & $\begin{array}{l}1.54 \\
0.19\end{array}$ & $\begin{array}{l}1.54 \\
0.21\end{array}$ \\
\hline
\end{tabular}

Table 3 (continued)

\begin{tabular}{|c|c|c|c|c|c|c|c|c|c|c|c|c|c|c|c|c|c|c|c|}
\hline & MIO-12-43 & MIO-12-19 & MIO-12-20 & BAR-00-28 ${ }^{1}$ & MIO-12-08 & MAM-11-3 ${ }^{1}$ & MAM-20 ${ }^{1}$ & $\begin{array}{l}\text { ARE-12 } 09 \\
\end{array}$ & MIO-12-05 & MAM-14 & CUM- $02^{1}$ & BAR-00-36 & ${ }^{1}$ BAR-00- $37^{1}$ & MIO-12-10 & MIO-12-46 & MIO-12-40 & MIO-12-49 & MIO-12-04 & MIO-12-17 \\
\hline Group & Mio-55 & Mio-55 & Mio-55 & Mio-55 & Mio-55 & Mio-55 & Mio-55 & Mio-55 & Mio-55 & Mio-55 & Mio-55 & Mio-55 & Mio-55 & Mio-55 & Mio-55 & Mio-55 & Mio-55 & Mio-60 & Mio-60 \\
\hline Latitude & -73.622 & -72.702 & -72.719 & -72.632 & -72.001 & -69.372 & -69.340 & -72.167 & -73.278 & -69.382 & -69.197 & -70.681 & -70.281 & -72.591 & -73.496 & -73.477 & -71.676 & -74.326 & -72.360 \\
\hline Longitude & -14.420 & -15.054 & -14.919 & -15.704 & -15.149 & -19.047 & -19.010 & -15.057 & -14.560 & -19.047 & -19.681 & -16.964 & -17.144 & -14.700 & -14.551 & -15.498 & -15.410 & -13.941 & -14.935 \\
\hline$\overline{\mathrm{SiO}_{2}}$ & $\begin{array}{ll}55.67 \\
\end{array}$ & 55.74 & 56.37 & 56.50 & 56.51 & 56.69 & 56.75 & 56.77 & 57.08 & 57.62 & 57.63 & 57.80 & 57.90 & 58.07 & 58.42 & 58.46 & 58.76 & 57.72 & 58.75 \\
\hline $\mathrm{TiO}_{2}$ & 1.50 & 1.11 & 1.07 & 0.89 & 1.22 & 0.71 & 0.95 & 1.41 & 1.14 & 0.67 & 0.96 & 0.73 & 0.80 & 1.13 & 1.10 & 0.88 & 1.22 & 1.23 & 0.94 \\
\hline $\mathrm{Al}_{2} \mathrm{O}_{3}$ & 16.59 & 16.29 & 16.31 & 16.80 & 17.11 & 17.64 & 17.75 & 16.89 & 16.41 & 19.06 & 18.54 & 18.30 & 17.40 & 16.66 & 17.01 & 17.36 & 16.80 & 15.99 & 15.97 \\
\hline $\mathrm{FeO}_{\mathrm{t}}$ & 9.03 & 7.44 & 7.46 & 7.75 & 6.89 & 6.41 & 7.70 & 7.13 & 5.95 & 6.05 & 7.73 & 7.04 & 7.24 & 6.26 & 7.57 & 6.60 & 6.36 & 7.82 & 6.30 \\
\hline $\mathrm{MnO}$ & 0.12 & 0.08 & 0.13 & 0.11 & 0.09 & 0.10 & 0.13 & 0.10 & 0.06 & 0.01 & 0.12 & 0.13 & 0.11 & 0.09 & 0.12 & 0.11 & 0.08 & 0.54 & 0.11 \\
\hline $\mathrm{MgO}$ & 3.18 & 3.95 & 3.28 & 4.40 & 3.12 & 3.51 & 2.92 & 3.32 & 2.15 & 2.54 & 3.03 & 2.76 & 3.71 & 2.86 & 2.49 & 2.56 & 2.41 & 0.74 & 3.15 \\
\hline $\mathrm{CaO}$ & 5.98 & 6.07 & 6.63 & 7.25 & 5.89 & 6.57 & 6.62 & 6.28 & 5.61 & 6.53 & 6.77 & 6.61 & 6.65 & 5.61 & 5.42 & 6.00 & 5.03 & 4.15 & 5.20 \\
\hline $\mathrm{Na}_{2} \mathrm{O}$ & 4.15 & 4.04 & 3.94 & 3.51 & 4.56 & 4.32 & 3.92 & 4.69 & 4.66 & 4.41 & 3.90 & 4.18 & 3.85 & 4.64 & 4.12 & 4.37 & 5.00 & 4.37 & 3.90 \\
\hline $\mathrm{K}_{2} \mathrm{O}$ & 2.48 & 2.70 & 2.73 & 1.73 & 2.42 & 1.45 & 1.82 & 2.51 & 2.14 & 1.45 & 1.83 & 1.31 & 1.88 & 2.74 & 2.81 & 2.03 & 2.82 & 3.21 & 3.23 \\
\hline $\mathrm{P}_{2} \mathrm{O}_{5}$ & 0.42 & 0.42 & 0.34 & 0.24 & 0.50 & 0.29 & 0.28 & 0.66 & 0.34 & 0.09 & 0.21 & 0.22 & 0.21 & 0.50 & 0.41 & 0.32 & 0.53 & 0.42 & 0.32 \\
\hline total & 99.12 & 97.83 & 98.27 & 99.18 & 98.31 & 97.69 & 98.84 & 99.75 & 95.54 & 98.43 & 100.72 & 99.08 & 99.75 & 98.56 & 99.47 & 98.68 & 99.01 & 96.19 & 97.87 \\
\hline $\mathrm{Rb}$ & 118.0 & 53.3 & 136.0 & 77.8 & 54.6 & 22.5 & 50.8 & 67.2 & 56.2 & 20.3 & 64.8 & 34.8 & 79.3 & 70.0 & 130.0 & 67.7 & 75.9 & 125.0 & 178.0 \\
\hline $\mathrm{Sr}$ & 242 & 176 & 330 & 758 & 482 & 633 & 565 & 605 & 322 & 578 & 458 & 758 & 774 & 546 & 295 & 323 & 470 & 195 & 302 \\
\hline Y & 30.7 & 12.2 & 27.9 & 45.6 & 18.7 & 12.2 & 17.6 & 20.5 & 14.7 & 13.8 & 21.5 & 19.6 & 17.2 & 18.0 & 27.0 & 21.2 & 16.4 & 41.3 & 26.0 \\
\hline $\mathrm{Zr}$ & 144 & 143 & 132 & 216 & 172 & 121 & 135 & 241 & 119 & 116 & 151 & 148 & 142 & 136 & 150 & 214 & 194 & 174 & 159 \\
\hline $\mathrm{Nb}$ & 13.2 & 6.9 & 14.7 & 8.5 & 11.7 & 4.4 & 6.8 & 12.6 & 8.8 & 4.1 & 6.7 & 4.6 & 7.2 & 12.7 & 13.2 & 8.6 & 13.1 & 18.3 & 15.2 \\
\hline $\mathrm{Ta}$ & 0.81 & 0.39 & 1.00 & 0.5 & 0.62 & 0.3 & 0.5 & 0.58 & 0.44 & 0.3 & 0.5 & 0.2 & 0.5 & 0.65 & 0.79 & 0.50 & 0.62 & 1.10 & 1.01 \\
\hline $\mathrm{Ba}$ & 643 & 451 & 782 & 816 & 426 & 639 & 717 & 434 & 792 & 602 & 573 & 679 & 810 & 449 & 832 & 761 & 433 & 795 & 874 \\
\hline $\mathrm{Pb}$ & 8.7 & 10.6 & 18.7 & 12.9 & 12.5 & 7.7 & 8.5 & 10.1 & 9.6 & 7.6 & 9.0 & 9.5 & 11.4 & 12.2 & 11.7 & 9.1 & 11.0 & 18.4 & 15.7 \\
\hline Hf & 7.57 & 3.21 & 6.94 & 5.9 & 6.05 & 3.0 & 3.5 & 5.41 & 6.19 & 3.0 & 3.9 & 3.9 & 4.1 & 6.59 & 7.58 & 4.95 & 6.90 & 8.94 & 8.23 \\
\hline Th & 13.60 & 5.99 & 21.40 & 7.1 & 7.86 & 1.0 & 4.9 & 6.74 & 4.40 & 1.0 & 5.9 & 2.9 & 6.3 & 8.46 & 14.10 & 6.36 & 7.19 & 13.00 & 27.40 \\
\hline U & 2.81 & 1.04 & 4.46 & 1.1 & 1.94 & 0.3 & 1.1 & 1.04 & 0.81 & 0.3 & 1.6 & 0.6 & 1.1 & 1.32 & 2.67 & 1.17 & 1.11 & 3.35 & 5.75 \\
\hline $\mathrm{Ni}$ & 9.1 & 17.8 & 25.7 & 57.6 & 28.3 & 15.8 & 5.0 & 27.0 & 11.2 & 6.9 & 8.5 & 9.1 & 30.5 & 23.7 & 5.9 & 9.9 & 13.1 & 1.6 & 25.7 \\
\hline $\mathrm{La}$ & 43.1 & 27.6 & 57.7 & 43.9 & 62.5 & 15.2 & 21.7 & 78.4 & 40.2 & 12.1 & 19.1 & 20.4 & 27.7 & 77.1 & 49.4 & 34.7 & 65.8 & 50.5 & 63.6 \\
\hline $\mathrm{Ce}$ & 92.9 & 56.1 & 117.0 & 73.2 & 121.0 & 28.8 & 42.9 & 54.2 & 79.9 & 24.8 & 38.9 & 39.8 & 53.4 & 54.3 & 103.0 & 70.1 & 132.0 & 108.0 & 126.0 \\
\hline $\operatorname{Pr}$ & 10.70 & 6.09 & 12.60 & 11.64 & 13.20 & 3.91 & 5.64 & 17.00 & 9.40 & 3.37 & 5.15 & 5.38 & 6.44 & 16.00 & 11.50 & 8.00 & 14.60 & 12.20 & 13.40 \\
\hline $\mathrm{Nd}$ & 42.0 & 22.6 & 46.4 & 48.2 & 48.5 & 16.2 & 23.0 & 62.1 & 36.8 & 14.1 & 21.4 & 22.8 & 25.3 & 57.8 & 43.7 & 30.9 & 53.6 & 47.1 & 47.5 \\
\hline $\mathrm{Sm}$ & 8.38 & 3.94 & 8.07 & 9.89 & 7.93 & 3.02 & 4.25 & 9.57 & 6.71 & 2.83 & 4.36 & 4.59 & 4.75 & 8.80 & 8.17 & 5.72 & 8.72 & 9.24 & 8.05 \\
\hline $\mathrm{Eu}$ & 2.08 & 0.96 & 1.84 & 2.08 & 2.14 & 0.86 & 1.18 & 2.50 & 1.84 & 0.83 & 1.12 & 1.38 & 1.34 & 2.37 & 1.99 & 1.53 & 2.25 & 2.15 & 1.76 \\
\hline $\mathrm{Gd}$ & 7.13 & 3.10 & 6.53 & 9.59 & 6.05 & 2.56 & 3.68 & 7.33 & 5.05 & 2.50 & 3.93 & 4.35 & 4.60 & 6.54 & 6.59 & 4.61 & 6.30 & 7.88 & 6.36 \\
\hline $\mathrm{Tb}$ & 1.13 & 0.44 & 0.95 & 1.11 & 0.78 & 0.34 & 0.49 & 0.89 & 0.66 & 0.35 & 0.56 & 0.65 & 0.62 & 0.80 & 1.00 & 0.69 & 0.80 & 1.26 & 0.91 \\
\hline Dy & 5.91 & 2.24 & 4.99 & 7.68 & 3.52 & 1.96 & 2.92 & 3.89 & 2.97 & 2.19 & 3.37 & 3.72 & 3.21 & 3.49 & 5.20 & 3.69 & 3.48 & 7.01 & 4.69 \\
\hline Но & 1.10 & 0.42 & 0.97 & 1.34 & 0.63 & 0.39 & 0.57 & 0.68 & 0.48 & 0.45 & 0.69 & 0.72 & 0.60 & 0.61 & 0.98 & 0.70 & 0.59 & 1.38 & 0.88 \\
\hline Er & 2.89 & 1.16 & 2.71 & 4.61 & 1.66 & 0.97 & 1.46 & 1.82 & 1.21 & 1.20 & 1.84 & 2.08 & 1.69 & 1.65 & 2.57 & 1.97 & 1.54 & 3.80 & 2.47 \\
\hline $\mathrm{Tm}$ & 0.38 & 0.15 & 0.37 & 0.53 & 0.21 & 0.14 & 0.21 & 0.22 & 0.14 & 0.18 & 0.27 & 0.29 & 0.22 & 0.20 & 0.35 & 0.26 & 0.19 & 0.52 & 0.34 \\
\hline $\mathrm{Yb}$ & 2.51 & 1.04 & 2.51 & 3.92 & 1.40 & 0.94 & 1.41 & 1.43 & 0.89 & 1.21 & 1.81 & 1.87 & 1.36 & 1.35 & 2.29 & 1.80 & 1.23 & 3.53 & 2.31 \\
\hline $\mathrm{Lu}$ & 0.34 & 0.14 & 0.36 & 0.53 & 0.19 & 0.15 & 0.22 & 0.20 & 0.12 & 0.18 & 0.27 & 0.31 & 0.21 & 0.18 & 0.32 & 0.26 & 0.17 & 0.50 & 0.32 \\
\hline
\end{tabular}


Chapter 2 - Constraints on P-T conditions of crystallization and rates of magma formation before and after crustal thickening in the Central Andes

Table 3 (continued)

\begin{tabular}{|c|c|c|c|c|c|c|c|c|c|c|c|c|c|c|c|c|c|}
\hline & MIO-12-42 & MIO-12-01 & MIO-12-26 & MIO-12-48 & BAR-01-83 ${ }^{1}$ & MIO-12-14 & MIO-12-11 & MIO-12-50 & BAR-02-11 ${ }^{1}$ & ${ }^{1}$ HUY-94-165 & YAH-00-16 ${ }^{1}$ & ${ }^{1}$ MIO-12-18 & CUM-12 1 & MIO-12-27 & MIO-12-15 & MIO-12-45 & MIO-12-44 \\
\hline Group & $\begin{array}{l}\text { Mio-60 } \\
\end{array}$ & $\begin{array}{l}\text { Mio-60 } \\
\end{array}$ & Mio-60 & Mio-60 & Mio-60 & Mio-60 & Mio-60 & Mio-60 & Mio-60 & Mio-60 & Mio-60 & Mio-60 & Mio-60 & Mio-60 & Mio-60 & Mio-60 & Mio-60 \\
\hline Latitude & -73.533 & -74.407 & -73.178 & -71.701 & -71.170 & -72.698 & -72.742 & -71.400 & -71.400 & -69.674 & -73.460 & -72.351 & -69.167 & -73.194 & -72.533 & -73.740 & -73.646 \\
\hline Longituds & -14.306 & -14.409 & -15.178 & -15.393 & -15.306 & -14.707 & -14.755 & -15.699 & -15.699 & -18.050 & -15.508 & -14.957 & -19.608 & -15.174 & -14.727 & -14.657 & -14.564 \\
\hline$\overline{\mathrm{SiO}_{2}}$ & 59.19 & 59.60 & 59.65 & 59.73 & 59.80 & 60.70 & 60.94 & 60.94 & 61.00 & 61.00 & 61.60 & 62.10 & 62.95 & 63.10 & 63.36 & 63.57 & 63.94 \\
\hline $\mathrm{TiO}_{2}$ & 1.06 & 0.51 & 0.91 & 1.08 & 0.90 & 0.96 & 0.84 & 0.86 & 0.88 & 0.53 & 0.77 & 0.81 & 0.62 & 0.86 & 0.54 & 0.87 & 0.68 \\
\hline $\mathrm{Al}_{2} \mathrm{O}_{3}$ & 17.41 & 17.09 & 16.96 & 16.75 & 16.40 & 16.36 & 15.86 & 15.89 & 15.80 & 17.60 & 17.00 & 16.42 & 17.25 & 16.42 & 14.94 & 16.53 & 16.49 \\
\hline $\mathrm{FeO}_{\mathrm{t}}$ & 5.78 & 5.09 & 5.99 & 5.88 & 5.88 & 5.78 & 5.22 & 6.04 & 6.06 & 2.52 & 5.24 & 4.51 & 5.29 & 4.71 & 3.96 & 4.29 & 4.37 \\
\hline $\mathrm{MnO}$ & 0.08 & 0.12 & 0.14 & 0.08 & 0.12 & 0.10 & 0.08 & 0.09 & 0.09 & 0.12 & 0.12 & 0.08 & 0.11 & 0.07 & 0.09 & 0.05 & 0.12 \\
\hline $\mathrm{MgO}$ & 1.46 & 1.79 & 2.15 & 2.21 & 2.57 & 2.64 & 2.17 & 2.85 & 2.69 & 2.22 & 1.74 & 1.77 & 2.05 & 1.80 & 1.81 & 1.33 & 1.20 \\
\hline $\mathrm{CaO}$ & 5.19 & 4.81 & 4.81 & 4.69 & 5.28 & 5.04 & 4.29 & 4.84 & 4.70 & 5.76 & 4.25 & 3.93 & 4.84 & 4.19 & 3.06 & 4.15 & 3.65 \\
\hline $\mathrm{Na}_{2} \mathrm{O}$ & 4.11 & 4.44 & 4.33 & 4.88 & 3.48 & 4.47 & 4.34 & 3.73 & 3.52 & 3.45 & 4.49 & 4.41 & 3.89 & 4.96 & 3.94 & 4.84 & 4.98 \\
\hline $\mathrm{K}_{2} \mathrm{O}$ & 3.48 & 2.15 & 2.66 & 3.01 & 3.46 & 3.16 & 3.35 & 3.86 & 3.91 & 2.06 & 3.28 & 3.75 & 2.84 & 2.95 & 3.76 & 2.76 & 2.86 \\
\hline $\mathrm{P}_{2} \mathrm{O}_{5}$ & 0.43 & 0.29 & 0.31 & 0.46 & 0.30 & 0.35 & 0.30 & 0.26 & 0.26 & 0.22 & 0.38 & 0.34 & 0.21 & 0.35 & 0.26 & 0.31 & 0.30 \\
\hline total & 98.20 & 95.89 & 97.91 & 98.77 & 98.19 & 99.55 & 97.39 & 99.36 & 98.91 & 95.48 & 98.87 & 98.12 & 100.05 & 99.41 & 95.72 & 98.70 & 98.59 \\
\hline $\mathrm{Rb}$ & 110.0 & 58.5 & 104.0 & 88.6 & 164.9 & 120.0 & 138.0 & 167.0 & 224.3 & 36.7 & 42.0 & 163.0 & 107.3 & 79.7 & 147.0 & 78.7 & 87.4 \\
\hline $\mathrm{Sr}$ & 273 & 290 & 207 & 414 & 467 & 345 & 300 & 251 & 669 & 520 & 418 & 306 & 371 & 375 & 300 & 345 & 299 \\
\hline $\mathrm{Y}$ & 70.8 & 18.0 & 32.6 & 15.9 & 19.2 & 21.3 & 21.8 & 20.3 & 24.8 & 13.8 & 20.4 & 24.2 & 16.6 & 13.5 & 16.7 & 13.0 & 22.3 \\
\hline $\mathrm{Zr}$ & 298 & 211 & 250 & 140 & 222 & 261 & 229 & 280 & 291 & 134 & 247 & 143 & 163 & 253 & 77 & 193 & 283 \\
\hline $\mathrm{Nb}$ & 24.9 & 8.2 & 9.5 & 12.3 & 14.8 & 13.9 & 15.0 & 13.7 & 16.8 & 6.0 & 8.4 & 16.3 & 8.5 & 9.8 & 11.8 & 10.0 & 12.5 \\
\hline $\mathrm{Ta}$ & 1.54 & 0.49 & 0.61 & 0.62 & 1.1 & 0.92 & 1.12 & 0.93 & 1.3 & 0.4 & 0.5 & 1.09 & 0.8 & 0.51 & 0.95 & 0.61 & 0.71 \\
\hline $\mathrm{Ba}$ & 776 & 687 & 690 & 428 & 877 & 344 & 863 & 824 & 1,159 & 1,123 & 856 & 1,040 & 608 & 385 & 358 & 915 & 1,030 \\
\hline $\mathrm{Pb}$ & 21.1 & 10.9 & 7.3 & 12.4 & 11.4 & 13.6 & 15.2 & 14.8 & 21.4 & 8.5 & 10.6 & 14.9 & 11.7 & 12.5 & 18.7 & 14.1 & 13.5 \\
\hline $\mathrm{Hf}$ & 14.70 & 4.63 & 5.92 & 7.06 & 5.5 & 6.11 & 5.50 & 6.63 & 8.4 & 3.5 & 6.4 & 7.32 & 4.3 & 5.92 & 2.39 & 4.76 & 6.45 \\
\hline Th & 37.80 & 4.53 & 11.60 & 8.93 & 11.7 & 14.40 & 18.80 & 20.50 & 25.0 & 3.2 & 4.7 & 21.90 & 11.0 & 4.87 & 19.30 & 7.69 & 7.35 \\
\hline $\mathrm{U}$ & 8.08 & 1.01 & 1.94 & 1.38 & 2.9 & 2.98 & 4.15 & 3.62 & 5.0 & 0.5 & 1.0 & 4.78 & 2.8 & 0.85 & 4.36 & 1.64 & 1.60 \\
\hline $\mathrm{Ni}$ & 6.5 & 0.0 & -0.2 & 10.5 & 17.1 & 26.1 & 18.9 & 21.6 & 36.5 & 77.5 & 4.4 & 2.8 & 4.8 & 9.0 & 6.6 & 4.9 & 1.6 \\
\hline $\mathrm{La}$ & 114.0 & 30.2 & 37.0 & 63.8 & 32.3 & 57.3 & 51.9 & 53.6 & 59.5 & 18.0 & 24.6 & 62.6 & 20.0 & 45.0 & 42.9 & 47.3 & 46.5 \\
\hline $\mathrm{Ce}$ & 66.5 & 57.8 & 77.9 & 128.0 & 64.4 & 111.0 & 99.6 & 106.0 & 114.7 & 37.4 & 52.4 & 122.0 & 42.0 & 92.2 & 79.4 & 95.1 & 95.8 \\
\hline $\mathrm{Pr}$ & 23.50 & 6.60 & 8.89 & 13.70 & 7.50 & 11.80 & 10.60 & 11.00 & 13.22 & 4.40 & 6.76 & 12.90 & 5.05 & 10.20 & 8.14 & 10.60 & 10.40 \\
\hline $\mathrm{Nd}$ & 88.9 & 24.9 & 35.3 & 49.9 & 27.8 & 42.4 & 37.9 & 39.2 & 49.8 & 16.8 & 26.5 & 45.0 & 19.6 & 38.1 & 28.6 & 39.4 & 39.0 \\
\hline $\mathrm{Sm}$ & 15.30 & 4.49 & 7.27 & 8.04 & 5.24 & 7.07 & 6.47 & 6.61 & 8.44 & 3.10 & 5.55 & 7.41 & 3.67 & 6.50 & 4.74 & 6.67 & 6.79 \\
\hline Eu & 2.90 & 1.31 & 1.88 & 2.07 & 1.34 & 1.78 & 1.61 & 1.52 & 1.87 & 0.85 & 1.35 & 1.73 & 0.83 & 1.70 & 1.29 & 1.73 & 1.89 \\
\hline $\mathrm{Gd}$ & 13.40 & 3.69 & 6.21 & 5.81 & 4.58 & 5.56 & 5.14 & 5.24 & 7.69 & 2.82 & 5.04 & 5.90 & 3.19 & 4.65 & 3.83 & 4.76 & 5.38 \\
\hline $\mathrm{Tb}$ & 1.97 & 0.55 & 1.03 & 0.74 & 0.63 & 0.77 & 0.75 & 0.75 & 0.98 & 0.40 & 0.67 & 0.83 & 0.44 & 0.61 & 0.54 & 0.61 & 0.80 \\
\hline Dy & 10.30 & 2.93 & 5.83 & 3.31 & 3.65 & 3.88 & 3.84 & 3.84 & 4.95 & 2.41 & 3.51 & 4.21 & 2.69 & 2.70 & 2.82 & 2.66 & 4.14 \\
\hline Ho & 2.06 & 0.58 & 1.15 & 0.56 & 0.70 & 0.73 & 0.73 & 0.71 & 0.93 & 0.49 & 0.68 & 0.82 & 0.53 & 0.46 & 0.56 & 0.45 & 0.79 \\
\hline $\mathrm{Er}$ & 5.65 & 1.64 & 3.25 & 1.52 & 2.02 & 2.00 & 2.03 & 1.98 & 2.70 & 1.45 & 1.99 & 2.30 & 1.43 & 1.23 & 1.60 & 1.17 & 2.16 \\
\hline $\mathrm{Tm}$ & 0.73 & 0.23 & 0.45 & 0.18 & 0.28 & 0.27 & 0.28 & 0.27 & 0.34 & 0.21 & 0.29 & 0.32 & 0.22 & 0.15 & 0.23 & 0.14 & 0.29 \\
\hline $\mathrm{Yb}$ & 4.66 & 1.62 & 3.06 & 1.25 & 1.90 & 1.87 & 1.96 & 1.84 & 2.24 & 1.45 & 1.90 & 2.22 & 1.48 & 0.99 & 1.63 & 0.95 & 2.04 \\
\hline $\mathrm{Lu}$ & 0.68 & 0.24 & 0.44 & 0.17 & 0.29 & 0.26 & 0.27 & 0.25 & 0.35 & 0.23 & 0.30 & 0.32 & 0.22 & 0.14 & 0.23 & 0.13 & 0.29 \\
\hline
\end{tabular}

${ }^{1}$ Mamani et al., 2010

Table 4: Major, trace and REE analysis of Pliocene-Quaternary samples. APT-11-rock is of Late Jurassic age (133.1 Ma)

\begin{tabular}{|c|c|c|c|c|c|c|c|c|c|c|c|}
\hline & POM $152^{6}$ & CEUV $1^{6}$ & $\operatorname{PAR} 225^{6}$ & ELR $1^{6}$ & ELR-N $^{6}$ & LAS- $07-12^{2}$ & BAR-00-33 1 & LAS- $07-11^{2}$ & PAR-03-38 & BAR-00-19 & BAR-00-31 \\
\hline Group & Plio-50 & Plio-50 & Plio-50 & Plio-50 & Plio-50 & Plio-55 & Plio-55 & Plio-55 & Plio-55 & Plio-60 & Plio-60 \\
\hline Latitude & -69.103 & -68.165 & -69.160 & -68.614 & -69.183 & -67.751 & -72.748 & -67.751 & -69.151 & -73.738 & -72.748 \\
\hline Longitude & -18.100 & -21.584 & -18.209 & -20.844 & -18.487 & -23.334 & -15.614 & -23.400 & -18.175 & -15.231 & -15.614 \\
\hline $\mathrm{SiO}_{2}$ & 52.75 & 52.95 & 53.21 & 54.12 & 54.9 & 55.29 & 53.80 & 56.87 & 58 & 59.80 & 60.00 \\
\hline $\mathrm{TiO}_{2}$ & 1.76 & 1.42 & 1.64 & 1.67 & 1.69 & 0.83 & 1.09 & 0.94 & 1.32 & 0.93 & 0.67 \\
\hline $\mathrm{Al}_{2} \mathrm{O}_{3}$ & 16.47 & 17.15 & 15.9 & 15.55 & 15.86 & 16.64 & 16.80 & 17.01 & 16.5 & 17.20 & 17.40 \\
\hline $\mathrm{FeO}_{\mathrm{t}}$ & 7.97 & 9.24 & 8.79 & 8.42 & 8.18 & 7.97 & 7.64 & 7.85 & 6.86 & 6.16 & 5.71 \\
\hline $\mathrm{MnO}$ & 0.09 & 0.11 & 0.11 & 0.16 & 0.01 & 0.13 & 0.11 & 0.12 & 0.09 & 0.10 & 0.11 \\
\hline $\mathrm{MgO}$ & 4.2 & 5.18 & 5.05 & 4.69 & 4.29 & 5.32 & 4.39 & 4.27 & 2.93 & 2.22 & 2.02 \\
\hline $\mathrm{CaO}$ & 6.71 & 8.73 & 7.37 & 6.6 & 6.76 & 7.76 & 7.08 & 6.90 & 5.44 & 4.76 & 5.17 \\
\hline $\mathrm{Na}_{2} \mathrm{O}$ & 4.15 & 3.57 & 4.29 & 3.97 & 4.27 & 3.43 & 3.70 & 3.62 & 4.31 & 4.70 & 4.26 \\
\hline $\mathrm{K}_{2} \mathrm{O}$ & 2.46 & 1.5 & 2.67 & 2.66 & 2.51 & 1.18 & 2.57 & 1.54 & 2.94 & 2.49 & 2.57 \\
\hline $\mathrm{P}_{2} \mathrm{O}_{5}$ & 0.48 & 0.27 & 0.8 & 0.7 & 0.73 & 0.23 & 0.47 & 0.24 & 0.49 & 0.36 & 0.39 \\
\hline total & 97.04 & 100.12 & 99.83 & 98.54 & 99.20 & 98.78 & 97.65 & 99.36 & 98.88 & 98.72 & 98.30 \\
\hline $\mathrm{Rb}$ & 50.0 & 28.0 & 49.0 & 41.0 & 44.0 & & 72.4 & & 69.9 & 59.7 & 25.2 \\
\hline $\mathrm{Sr}$ & 1025 & 796 & 1944 & 1298 & 1347 & & 1363 & & 989 & 573 & 646 \\
\hline Y & 18.0 & 22.0 & 24.0 & 26.0 & 21.0 & 17.7 & & 15.4 & 22.9 & 12.3 & \\
\hline $\mathrm{Zr}$ & 217 & 284 & 233 & 284 & 104 & & 227 & & 261 & 235 & 186 \\
\hline $\mathrm{Nb}$ & 13.0 & 7.0 & 16.0 & 21.0 & 20.0 & & 10.8 & & 12.0 & 12.7 & 6.9 \\
\hline $\mathrm{Ta}$ & 0.5 & 0.89 & & 0.95 & 0.92 & 0.5 & & 0.7 & 0.8 & 0.4 & \\
\hline $\mathrm{Ba}$ & 1164 & 386 & 1867 & 1408 & 1914 & & 1314 & & 1438 & 664 & 918 \\
\hline $\mathrm{Pb}$ & 18.0 & & 23.0 & & & & 13.0 & & 14.1 & 12.4 & 9.2 \\
\hline $\mathrm{Hf}$ & & & & & & 3.3 & 6.0 & 4.0 & 6.5 & 6.0 & 4.6 \\
\hline Th & 1.49 & 2.28 & & 3.51 & 3.19 & 4.1 & 6.5 & 4.7 & 7.1 & 8.1 & 4.3 \\
\hline $\mathrm{U}$ & 0.9 & 0.79 & & 0.85 & 0.54 & 1.1 & 1.1 & 1.3 & 0.9 & 2.1 & 0.8 \\
\hline $\mathrm{Ni}$ & 34.0 & 30.0 & 24.0 & 71.0 & 81.0 & & 48.2 & & 19.5 & 1.8 & 4.8 \\
\hline $\mathrm{La}$ & & 15.0 & & 53.0 & 60.0 & 18.0 & 54.8 & 18.0 & 47.0 & 24.5 & 26.0 \\
\hline $\mathrm{Ce}$ & & 40.0 & & 108.0 & 117.0 & 38.0 & 114.0 & 49.0 & 93.2 & 55.8 & 51.9 \\
\hline $\mathrm{Pr}$ & & & & & & & 13.45 & & 11.55 & 6.64 & 6.45 \\
\hline $\mathrm{Nd}$ & & 29.0 & & 57.0 & 60.0 & 22.4 & 53.1 & 25.3 & 45.5 & 27.2 & 23.6 \\
\hline $\mathrm{Sm}$ & & 6.10 & & 9.00 & 10.70 & 5.10 & 8.42 & 5.60 & 7.62 & 5.71 & 4.33 \\
\hline Eu & & 1.50 & & 2.50 & 2.80 & & 2.19 & & 1.99 & 1.40 & 1.19 \\
\hline $\mathrm{Gd}$ & & 6.50 & & 8.40 & & & 7.28 & & 5.87 & 5.40 & 3.79 \\
\hline $\mathrm{Tb}$ & & 0.74 & & 0.76 & 0.90 & & 0.85 & & 0.66 & 0.75 & 0.47 \\
\hline Dy & & 3.70 & & 3.20 & 4.32 & & 3.95 & & 3.30 & 4.03 & 2.24 \\
\hline Но & & & & & & & 0.69 & & 0.59 & 0.77 & 0.43 \\
\hline $\mathrm{Er}$ & & & & & & & 1.99 & & 1.54 & 2.12 & 1.26 \\
\hline $\mathrm{Tm}$ & & 0.40 & & 0.28 & & & 0.24 & & 0.20 & 0.28 & 0.18 \\
\hline $\mathrm{Yb}$ & & 1.52 & & 1.14 & 1.51 & 2.70 & 1.51 & 2.80 & 1.25 & 1.84 & 1.14 \\
\hline $\mathrm{Lu}$ & & 0.22 & & 0.17 & 0.22 & & 0.23 & & 0.18 & 0.28 & 0.18 \\
\hline
\end{tabular}


Chapter 2 - Constraints on P-T conditions of crystallization and rates of magma formation before and after crustal thickening in the Central Andes

Table 4 (continued)

\begin{tabular}{|c|c|c|c|c|c|c|c|c|c|c|c|}
\hline & LAS-07-0 $5^{2}$ & MIS-99-04 ${ }^{4}$ & LAS-07-01 ${ }^{2}$ & PAR-03-02 ${ }^{3}$ & BAR-00-44 ${ }^{1}$ & LAS-07-02 ${ }^{2}$ & ${ }^{2}$ PAR-04-0 $7^{3}$ & MIN $02^{1}$ & PAR- $03-36^{3}$ & BAR-01-52 ${ }^{1}$ & APT-11-rock ${ }^{1,5}$ \\
\hline $\begin{array}{l}\text { Group } \\
\end{array}$ & $\begin{array}{l}\text { Plio-60 } \\
\end{array}$ & Plio-60 & Plio-60 & Plio-60 & Plio-60 & Plio-60 & Plio-60 & Plio-60 & Plio-60 & Plio-60 & \\
\hline Latitude & -67.808 & -71.467 & -67.816 & -69.175 & -69.770 & -67.816 & -69.129 & -68.583 & -69.141 & -71.395 & -18.47979476 \\
\hline Longitude & -23.346 & -16.433 & -23.355 & -18.187 & -17.583 & -23.353 & -18.208 & -21.183 & -18.198 & -16.001 & -70.32545775 \\
\hline$\overline{\mathrm{SiO}_{2}}$ & 60.40 & 60.50 & 60.97 & 61.00 & 61.30 & 61.50 & 61.60 & 61.70 & 61.70 & 64.30 & 54.58 \\
\hline $\mathrm{TiO}_{2}$ & 0.71 & 0.69 & 0.71 & 1.11 & 0.71 & 0.66 & 1.09 & 0.64 & 1.11 & 0.68 & 1.27 \\
\hline $\mathrm{Al}_{2} \mathrm{O}_{3}$ & 17.85 & 17.20 & 17.62 & 15.70 & 16.90 & 16.34 & 15.50 & 16.89 & 15.40 & 17.00 & 16.54 \\
\hline $\mathrm{FeO}_{\mathrm{t}}$ & 5.67 & 5.60 & 5.63 & 5.73 & 5.41 & 5.57 & 5.36 & 5.25 & 5.41 & 4.39 & 9.75 \\
\hline $\mathrm{MnO}$ & 0.10 & 0.10 & 0.10 & 0.08 & 0.09 & 0.10 & 0.07 & 0.08 & 0.07 & 0.10 & 0.13 \\
\hline $\mathrm{MgO}$ & 2.50 & 2.68 & 2.49 & 2.73 & 2.33 & 2.84 & 2.24 & 2.78 & 2.26 & 1.39 & 3.68 \\
\hline $\mathrm{CaO}$ & 5.95 & 5.35 & 5.85 & 4.83 & 5.03 & 5.24 & 4.21 & 4.98 & 4.29 & 3.86 & 9.15 \\
\hline $\mathrm{Na}_{2} \mathrm{O}$ & 3.93 & 4.25 & 3.95 & 4.26 & 4.23 & 3.59 & 4.37 & 4.05 & 4.43 & 4.73 & 2.64 \\
\hline $\mathrm{K}_{2} \mathrm{O}$ & 1.89 & 2.30 & 1.96 & 3.19 & 2.43 & 2.26 & 3.40 & 2.69 & 3.41 & 3.11 & 0.69 \\
\hline $\mathrm{P}_{2} \mathrm{O}_{5}$ & 0.24 & & 0.24 & 0.14 & 0.24 & 0.21 & 0.43 & 0.20 & 0.44 & 0.28 & 0.35 \\
\hline total & 99.24 & 98.67 & 99.52 & 98.77 & 98.67 & 98.31 & 98.27 & 99.26 & 98.52 & 99.84 & 98.78 \\
\hline $\mathrm{Rb}$ & & 42.7 & & & 65.9 & & 55.8 & 63.0 & 78.8 & 87.9 & 18.3 \\
\hline $\mathrm{Sr}$ & & 772 & & & 567 & & 796 & 613 & 860 & 736 & 459 \\
\hline Y & & & & 10.5 & & 10.8 & 10.3 & 11.5 & 20.6 & & \\
\hline $\mathrm{Zr}$ & & 156 & & & 141 & & 219 & 143 & 196 & 296 & 234 \\
\hline $\mathrm{Nb}$ & & 6.0 & & & 6.9 & & 10.9 & 6.2 & 11.5 & 12.1 & 8.0 \\
\hline $\mathrm{Ta}$ & 0.3 & & & 0.5 & & 0.8 & 0.4 & 0.8 & 0.6 & & \\
\hline $\mathrm{Ba}$ & & 943 & & & 841 & & 1355 & 837 & 1338 & 1276 & 260 \\
\hline $\mathrm{Pb}$ & & 14.3 & & & 12.1 & & 14.8 & 11.7 & 15.7 & 18.6 & \\
\hline $\mathrm{Hf}$ & 4.6 & 4.1 & 4.5 & & 3.8 & 4.0 & 5.6 & 3.6 & 5.2 & 7.7 & \\
\hline Th & 6.9 & 2.8 & 6.9 & & 5.4 & 7.6 & 10.0 & 4.7 & 10.0 & 8.2 & \\
\hline $\mathrm{U}$ & 1.8 & 0.4 & 1.8 & & 1.4 & 2.0 & 1.7 & 1.0 & 1.9 & 1.0 & \\
\hline $\mathrm{Ni}$ & & 21.2 & & & 11.1 & & 17.6 & 18.7 & 19.4 & 0.9 & 16.1 \\
\hline $\mathrm{La}$ & 22.0 & 26.4 & 26.0 & & 21.7 & 28.0 & 41.4 & 19.0 & 50.4 & 45.9 & 21.2 \\
\hline $\mathrm{Ce}$ & 49.0 & 53.7 & 48.0 & & 45.0 & 50.0 & 85.2 & 39.0 & 95.4 & 96.3 & 50.8 \\
\hline $\mathrm{Pr}$ & & 6.27 & & & 5.24 & & 9.66 & 4.61 & 11.63 & 10.72 & 7.2 \\
\hline $\mathrm{Nd}$ & 24.1 & 23.5 & 25.4 & & 19.9 & 26.5 & 37.2 & 17.4 & 45.0 & 41.1 & 29.6 \\
\hline $\mathrm{Sm}$ & 5.20 & 4.01 & 5.50 & & 3.66 & 5.50 & 6.00 & 3.22 & 7.25 & 6.88 & 7.1 \\
\hline $\mathrm{Eu}$ & & 1.08 & & & 0.97 & & 1.57 & 0.87 & 1.84 & 1.82 & 1.7 \\
\hline $\mathrm{Gd}$ & & 3.21 & & & 3.12 & & 4.32 & 2.68 & 5.49 & 6.23 & 6.9 \\
\hline $\mathrm{Tb}$ & & 0.40 & & & 0.40 & & 0.46 & 0.36 & 0.58 & 0.79 & 1.2 \\
\hline Dy & & 2.23 & & & 2.24 & & 2.29 & 2.02 & 2.71 & 4.10 & 6.3 \\
\hline Ho & & 0.41 & & & 0.41 & & 0.37 & 0.38 & 0.47 & 0.78 & 1.4 \\
\hline $\mathrm{Er}$ & & 1.10 & & & 1.15 & & 0.67 & 1.01 & 1.20 & 2.27 & 3.8 \\
\hline $\mathrm{Tm}$ & & 0.15 & & & 0.16 & & 0.12 & 0.14 & 0.16 & 0.31 & 0.6 \\
\hline $\mathrm{Yb}$ & 2.60 & 0.99 & 2.40 & & 1.06 & 3.20 & 0.73 & 0.89 & 0.94 & 2.01 & 3.6 \\
\hline $\mathrm{Lu}$ & 0.15 & & & 0.16 & & 0.11 & 0.14 & 0.14 & 0.32 & 0.6 & \\
\hline
\end{tabular}

${ }^{1}$ Mamani et al., 2010; ${ }^{2}$ Banaszak et al., unpublished; ${ }^{3}$ Hora et al., 2007; ${ }^{4}$ Wörner and Thouret, unpublished; ${ }^{5}$ Wörner et al., 2000.

Whereas the major elements with XRF only show minor variations within a certain group (Fig. 8-10), there are significant variations in incompatible trace elements (Fig. 11). They display a relative uniform typical arc signature characterized by a strong enrichment of $\mathrm{Rb}$ and $\mathrm{Ba}$ combined with the $\mathrm{Nb}-\mathrm{Ta}$ trough probably reflecting large amount of crustal material. A Sr though occurs within only for the Miocene samples. The absence of a clear negative Eu anomaly indicates that plagioclase fractionation is insignificant even within the more evolved samples with abundant plagioclase phenocrysts. Only in the case of Mio-50 and Mio-55 there seem to be a few samples with a slight positive anomaly of Eu. Eu/Eu* ranges for Mio-50 between $0.12-0.17$, for Mio-55 between $0.11-0.16$, for Mio-60 between $0.12-0.16$ and for the Pliocene/Quaternary samples Plio-55 between $0.14-0.15$ and for Plio-60 between $0.13-0.15$ showing little to no variation.

Having Mio-50 as the least evolved group as a reference it is easy to compare all five groups together. From Mio-50 to Mio-55 to Mio-60 and Plio-55 to Plio-60 a slight increase is displayed within the LILE and LREE and a stronger depletion of HREE occurs for most samples showing differentiation as one of the major processes. Furthermore Plio-55 and Plio-60 have steeper slopes as the Miocene groups, showing an increase of slope through time as HREE become more depleted than LREE. 

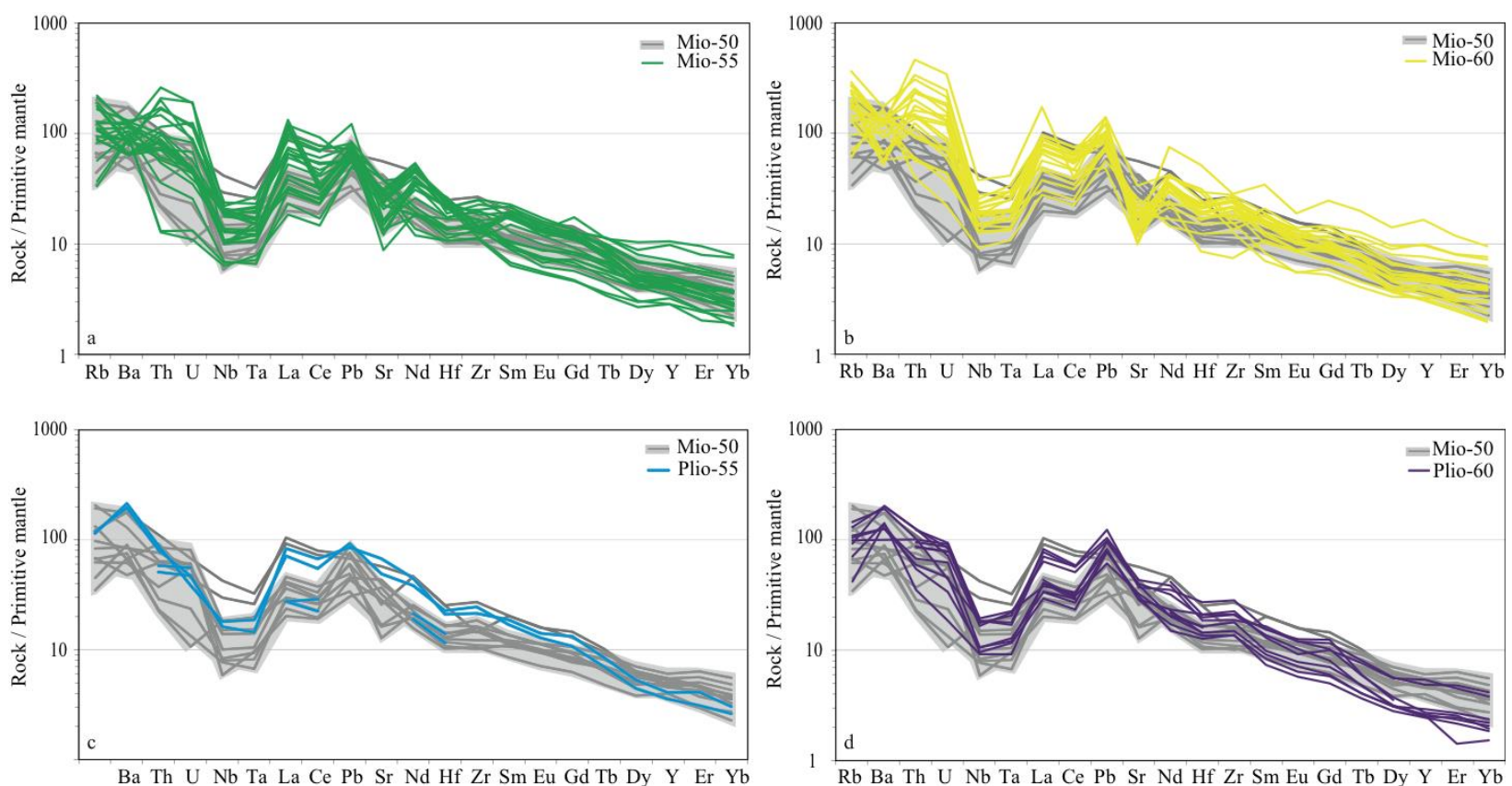

Fig. 11: Trace element patterns normalized to primitive mantle (Sun and McDonough, 1989). (a) Mio-50 compared to Mio-

55 showing a slight increase in LREE and a decrease in HREE for Mio 55. (b) A Further increase and decrease is shown for

Mio-60. (c-d) Comparing Mio-50 to Plio-55 and Plio-60 shows no changes within the REE.

\subsubsection{Volumes through time}

Using volume calculations, the extent and volume of lava flows comparing Miocene and Pliocene/Quaternary lava flows for three different arc segments were estimated (Fig. 1). A clear distinction between Miocene (mean of $0.45 \mathrm{~km}^{3}$ ) and Pliocene/Quaternary (mean of $0.24 \mathrm{~km}^{3}$ ) volcanoes can be seen from figure 12 and tables 5 and 6 . Where small lava flows are more abundant for the Pliocene/Quaternary volcanoes, the Miocene lava flows are generally larger. Within these calculations the amount of erosion has not been taken into account and thus are the present volumes. Since, especially the Miocene lava shields are partially eroded on the margins, erosion need to be considered as well. A method to estimate erosion was developed by Karátson et al, (2011), so the original volume can be calculated. However, this method is designed for entire volcanic edifices rather than for individual lava flows, but it can give an indication of the original volumes. In this case the Miocene is mean $0.80 \mathrm{~km}^{3}$ and Pliocene/Quaternary has a mean of $0.24 \mathrm{~km}^{3}$.

The results for the present and the original volume calculation for both Miocene and Pliocene/Quaternary flows are shown in table 5 and 6. Despite large uncertainties, especially for the Miocene flows, the averages clearly indicate higher volume lava flows during the Miocene. Besides volume also the covered area by a flow is much larger of the Miocene lava flows with a range of 0.78 to $35 \mathrm{~km}^{2}$ with a median of approximately $7 \mathrm{~km}^{2}$, while for the Pliocene/Quaternary flows the range is 0.21 to $33 \mathrm{~km}^{2}$ but with a median of approximately $4 \mathrm{~km}^{2}$ (see table 5 and 6).

Together these results provide important insights into different magmatic regimes leading to two different end products: (1) Miocene shields with voluminous long simple lava flows; (2) 
Chapter 2 - Constraints on P-T conditions of crystallization and rates of magma formation before and after crustal thickening in the Central Andes

Pliocene/Quaternary stratovolcanoes with many small compound lava flows (further explained within the discussion).
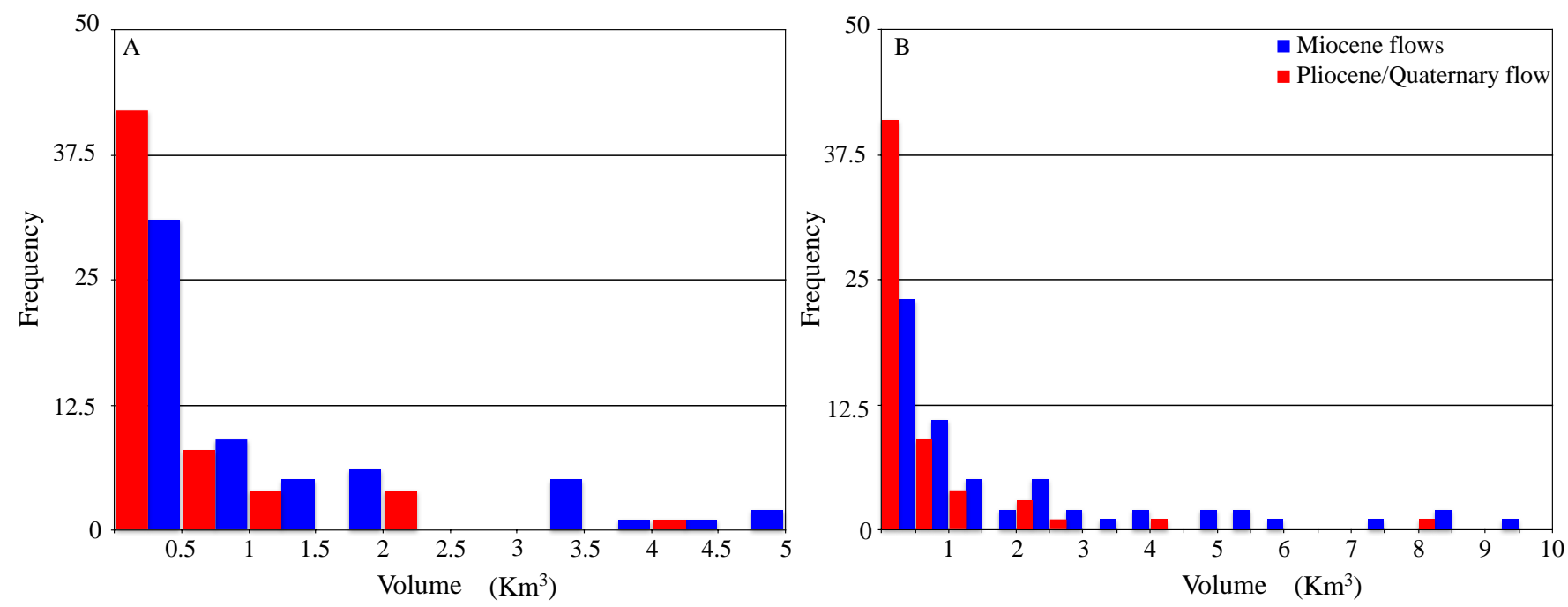

Fig. 12: Frequency distribution of Miocene (blue) and Pliocene/Quaternary (red) lava flows for volume. (A) present volume histogram (without erosion). (B) original volumes calculated with the method of Karátson et al, (2011). 
Chapter 2 - Constraints on P-T conditions of crystallization and rates of magma formation before and after crustal thickening in the Central Andes

Table 5: Present (without erosion) and original volumes (with erosion) for Miocene individual lava flows including the used estimated volume erosion and the degree of denudation for the area between $14{ }^{\circ} \mathrm{S}$ and $25^{\circ} \mathrm{S}$. For Areas see Fig. 1.

\begin{tabular}{|c|c|c|c|c|c|c|c|c|c|c|}
\hline & Area & Lat. & Long. & $\begin{array}{c}\text { Average } \\
\text { Thickness (m) }\end{array}$ & km & Area $\left(\mathrm{m}^{2}\right)$ & $\begin{array}{l}\text { Present } \\
\text { volume }\end{array}$ & Erosion & $\begin{array}{c}\text { Degree of } \\
\text { denudation }\end{array}$ & $\begin{array}{c}\text { Original } \\
\text { volume }\end{array}$ \\
\hline 1 & 1 & -14.1231 & -74.7906 & 43 & 0.043 & 6.7 & 0.29 & 0.30 & $\overline{251}$ & 0.59 \\
\hline 2 & 1 & -13.8184 & -74.6202 & 68 & 0.068 & 17.6 & 1.20 & 1.30 & 52 & 2.50 \\
\hline 3 & 1 & -14.4284 & -74.3575 & 137 & 0.137 & 13.1 & 1.79 & 1.80 & 51 & 3.53 \\
\hline 4 & 1 & -14.1654 & -74.3502 & 96 & 0.096 & 4.4 & 0.42 & 0.40 & 49 & 0.82 \\
\hline 5 & 1 & -14.4768 & -73.9221 & 52 & 0.052 & 3.2 & 0.17 & 0.19 & 53 & 0.36 \\
\hline 6 & 1 & -14.7554 & -73.9124 & 56 & 0.056 & 1.7 & 0.09 & 0.10 & 53 & 0.19 \\
\hline 7 & 1 & -14.7244 & -73.7305 & 112 & 0.112 & 6.2 & 0.69 & 0.66 & 49 & 1.35 \\
\hline 8 & 1 & -14.3130 & -73.7596 & 119 & 0.119 & 26.1 & 3.11 & 2.21 & 41.6 & 5.31 \\
\hline 9 & 1 & -14.5117 & -73.5154 & 125 & 0.125 & 35.9 & 4.48 & 4.85 & 52 & 9.33 \\
\hline 10 & 1 & -14.7629 & -72.6500 & 48 & 0.048 & 8.7 & 0.42 & 0.47 & 53 & 0.89 \\
\hline 11 & 1 & -14.9874 & -72.3388 & 39 & 0.039 & 3.6 & 0.14 & 0.12 & 47 & 0.26 \\
\hline 12 & 1 & -15.3367 & -72.1563 & 40 & 0.040 & 10.3 & 0.41 & 0.38 & 48 & 0.79 \\
\hline 13 & 1 & -15.2498 & -71.2508 & 44 & 0.044 & 2.7 & 0.12 & 0.13 & 52 & 0.25 \\
\hline 14 & 1 & -14.3265 & -74.4492 & 28 & 0.028 & 8.3 & 0.23 & 0.25 & 52 & 0.48 \\
\hline 15 & 1 & -14.8604 & -72.3125 & 94 & 0.094 & 19.9 & 1.86 & 2.01 & 52 & 3.87 \\
\hline 16 & 1 & -15.0841 & -71.8094 & 151 & 0.151 & 26.2 & 3.96 & 4.12 & 51 & 8.08 \\
\hline 17 & 1 & -15.8403 & -71.6659 & 43 & 0.043 & 7.2 & 0.31 & 0.30 & 49 & 0.61 \\
\hline 18 & 1 & -15.5252 & -71.6909 & 28 & 0.028 & 4.1 & 0.11 & 0.08 & 43 & 0.19 \\
\hline 19 & 1 & -15.4046 & -73.4372 & 55 & 0.055 & 25.6 & 1.40 & 1.29 & 48 & 2.69 \\
\hline 20 & 1 & -15.0255 & -72.4738 & 36 & 0.036 & 5.8 & 0.21 & 0.21 & 50 & 0.42 \\
\hline 21 & 2 & -18.136 & -68.338 & 109 & 0.109 & 7.7 & 0.84 & 0.71 & 46 & 1.54 \\
\hline 22 & 2 & -16.845 & -69.897 & 24 & 0.024 & 0.78 & 0.02 & 0.02 & 43 & 0.03 \\
\hline 23 & 2 & -16.246 & -70.346 & 191 & 0.191 & 24.1 & 4.59 & 2.69 & 37 & 7.27 \\
\hline 24 & 2 & -16.922 & -70.613 & 77 & 0.077 & 3.7 & 0.28 & 0.12 & 31 & 0.39 \\
\hline 25 & 2 & -17.374 & -70.028 & 179 & 0.179 & 26.7 & 4.77 & 3.60 & 43 & 8.37 \\
\hline 26 & 2 & -16.879 & -69.569 & 196 & 0.196 & 9.1 & 1.78 & 1.58 & 47 & 3.36 \\
\hline 27 & 2 & -17.189 & -69.878 & 38 & 0.038 & 2 & 0.08 & 0.04 & 36 & 0.12 \\
\hline 28 & 2 & -16.479 & -69.891 & 110 & 0.110 & 8.2 & 0.90 & 0.49 & 35 & 1.39 \\
\hline 29 & 2 & -16.651 & -70.080 & 68 & 0.068 & 3.3 & 0.23 & 0.20 & 46 & 0.43 \\
\hline 30 & 2 & -15.983 & -70.758 & 66 & 0.066 & 5.9 & 0.39 & 0.37 & 49 & 0.76 \\
\hline 31 & 2 & -17.008 & -69.789 & 82 & 0.082 & 19 & 1.55 & 0.73 & 32 & 2.28 \\
\hline 32 & 2 & -18.715 & -69.475 & 107 & 0.107 & 4.4 & 0.47 & 0.20 & 29.59 & 0.68 \\
\hline 33 & 3 & -19.577 & -67.673 & 57 & 0.057 & 4.4 & 0.25 & 0.15 & 38 & 0.40 \\
\hline 34 & 3 & -18.952 & -66.691 & 121 & 0.121 & 12.7 & 1.53 & 1.06 & 41 & 2.59 \\
\hline 35 & 3 & -19.82 & -68.199 & 71 & 0.071 & 2.1 & 0.15 & 0.05 & 26.7 & 0.20 \\
\hline 36 & 3 & -20.607 & -68.496 & 54 & 0.054 & 15.3 & 0.83 & 0.39 & 32 & 1.22 \\
\hline 37 & 3 & -20.56 & -68.318 & 40 & 0.040 & 3 & 0.12 & 0.06 & 34 & 0.18 \\
\hline 38 & 3 & -20.65 & -67.669 & 100 & 0.100 & 3.8 & 0.38 & 0.19 & 33 & 0.57 \\
\hline 39 & 3 & -21.074 & 67.855 & 78 & 0.078 & 18.5 & 1.45 & 0.59 & 29 & 2.04 \\
\hline 40 & 3 & -21.513 & 67.754 & 57 & 0.057 & 5.9 & 0.33 & 0.15 & 31.5 & 0.48 \\
\hline 41 & 3 & -22.009 & -67.218 & 61 & 0.061 & 18.2 & 1.11 & 0.65 & 37 & 1.76 \\
\hline 42 & 3 & -22.177 & -66.687 & 133 & 0.133 & 25.3 & 3.37 & 2.34 & 41 & 5.71 \\
\hline 43 & 3 & -22.276 & -67.925 & 58 & 0.058 & 3.5 & 0.20 & 0.07 & 25.7 & 0.27 \\
\hline 44 & 3 & -25.219 & -68.329 & 113 & 0.113 & 2.9 & 0.33 & 0.11 & 25.1 & 0.44 \\
\hline 45 & 3 & -25.688 & -67.382 & 86 & 0.086 & 14.2 & 1.21 & 0.84 & 41 & 2.05 \\
\hline 46 & 3 & -22.733 & -67.551 & 85 & 0.085 & 0.9 & 0.08 & 0.04 & 34.8 & 0.12 \\
\hline 47 & 3 & -23.027 & -67.039 & 116 & 0.116 & 28.6 & 3.30 & 2.17 & 39.7 & 5.47 \\
\hline 48 & 3 & -18.804 & -68.306 & 70 & 0.070 & 3.7 & 0.26 & 0.09 & 25.8 & 0.35 \\
\hline 49 & 3 & -18.981 & -68.562 & 112 & 0.112 & 2.3 & 0.26 & 0.11 & 30.4 & 0.37 \\
\hline 50 & 3 & -19.343 & -68.987 & 113 & 0.113 & 2.4 & 0.27 & 0.16 & 37 & 0.43 \\
\hline 51 & 3 & -19.036 & -69.057 & 220 & 0.220 & 13.8 & 3.04 & 1.57 & 34 & 4.60 \\
\hline 52 & 3 & -21.979 & -68.072 & 118 & 0.118 & 2.4 & 0.28 & 0.08 & 21.8 & 0.36 \\
\hline 53 & 3 & -19.049 & -69.421 & 122 & 0.122 & 27.3 & 3.33 & 1.57 & 32 & 4.90 \\
\hline 54 & 3 & -22.477 & -66.765 & 110 & 0.110 & 6.5 & 0.71 & 0.52 & 42 & 1.23 \\
\hline 55 & 3 & -25.409 & -68.028 & 16 & 0.016 & 32.4 & 0.51 & 0.17 & 25 & 0.68 \\
\hline 56 & 3 & -19.724 & -68.815 & 91 & 0.091 & 9.4 & 0.85 & 0.40 & 32 & 1.25 \\
\hline 57 & 3 & -20.34 & -68.585 & 133 & 0.133 & 5.3 & 0.71 & 0.18 & 20.3 & 0.89 \\
\hline 58 & 3 & -20.131 & -68.769 & 154 & 0.154 & 11.1 & 1.70 & 0.48 & 22 & 2.18 \\
\hline 59 & 3 & -21.762 & -67.193 & 24 & 0.024 & 1.6 & 0.04 & 0.01 & 27 & 0.05 \\
\hline 60 & 3 & -19.078 & -68.704 & 89 & 0.089 & 8.3 & 0.73 & 0.20 & 21 & 0.93 \\
\hline Average & & & & & & 10.63 & 1.08 & & & 1.85 \\
\hline Median & & & & & & 6.95 & 0.45 & & & 0.80 \\
\hline Min & & & & & & 0.78 & 0.02 & & & 0.03 \\
\hline Max & & & & & & 35.90 & 4.77 & & & 9.33 \\
\hline Std. Dev. & & & & & & & 1.26 & & & 2.26 \\
\hline
\end{tabular}


Chapter 2 - Constraints on P-T conditions of crystallization and rates of magma formation before and after crustal thickening in the Central Andes

Table 6: Present (without erosion) and original volumes (with erosion) for Pliocene to Quaternary individual lava flows for the area between $14{ }^{\circ} \mathrm{S}$ and $25^{\circ} \mathrm{S}$. For Areas see Fig. 1.

\begin{tabular}{|c|c|c|c|c|c|c|c|c|c|c|}
\hline & Area & Lat. & Long. & $\begin{array}{c}\text { Average } \\
\text { Thickness (m) }\end{array}$ & km & Area $\left(m^{2}\right)$ & $\begin{array}{l}\text { Present } \\
\text { volume }\end{array}$ & Erosion & $\begin{array}{c}\text { Degree of } \\
\text { denudation }\end{array}$ & $\begin{array}{c}\text { Original } \\
\text { volume }\end{array}$ \\
\hline 1 & 1 & -15.1865 & -73.646 & 114 & 0.114 & 18 & 2.04 & 0.25 & 11 & 2.27 \\
\hline 2 & 1 & -15.3306 & -73.446 & 36 & 0.036 & 4 & 0.15 & 0.00 & 1.8 & 0.17 \\
\hline 3 & 1 & -15.0729 & -73.188 & 70 & 0.070 & 18 & 1.25 & 0.02 & 1.3 & 1.23 \\
\hline 4 & 1 & -14.9976 & -72.955 & 86 & 0.086 & 1.4 & 0.12 & 0.01 & 5.4 & 0.13 \\
\hline 5 & 1 & -15.4032 & -72.913 & 89 & 0.089 & 25 & 2.21 & 0.04 & 1.9 & 2.26 \\
\hline 6 & 1 & -15.2610 & -72.734 & 18 & 0.018 & 1.1 & 0.02 & 0.00 & 15 & 0.02 \\
\hline 7 & 1 & -15.2356 & -72.644 & 56 & 0.056 & 9.4 & 0.52 & 0.03 & 5 & 0.54 \\
\hline 8 & 1 & -15.5582 & -72.637 & 20 & 0.020 & 3.6 & 0.07 & 0.00 & 2.8 & 0.07 \\
\hline 9 & 1 & -15.4214 & -72.363 & 59 & 0.059 & 4.1 & 0.24 & 0.00 & 0.2 & 0.25 \\
\hline 10 & 1 & -15.5434 & -72.290 & 48 & 0.048 & 3.9 & 0.19 & 0.00 & 0.2 & 0.20 \\
\hline 11 & 1 & -15.8201 & -71.878 & 69 & 0.069 & 4.2 & 0.29 & 0.00 & 0.5 & 0.30 \\
\hline 12 & 1 & -15.8201 & -71.878 & 42 & 0.042 & 11.5 & 0.48 & 0.00 & 0.5 & 0.48 \\
\hline 13 & 1 & -16.1939 & -71.530 & 93 & 0.093 & 9.4 & 0.87 & 0.02 & 2.1 & 0.90 \\
\hline 14 & 1 & -16.4417 & -71.240 & 115 & 0.115 & 3.6 & 0.41 & 0.06 & 12 & 0.48 \\
\hline 15 & 1 & -16.4700 & -71.144 & 164 & 0.164 & 13.1 & 2.15 & 0.38 & 15 & 2.53 \\
\hline 16 & 1 & -16.3609 & -70.924 & 44 & 0.044 & 0.34 & 0.02 & 0.00 & 0.8 & 0.02 \\
\hline 17 & 1 & -16.2660 & -71.198 & 135 & 0.135 & 5.6 & 0.76 & 0.11 & 13 & 0.85 \\
\hline 18 & 1 & -16.1819 & -71.112 & 79 & 0.079 & 3.2 & 0.25 & 0.04 & 14 & 0.29 \\
\hline 19 & 1 & -16.169 & -70.962 & 47 & 0.047 & 4.4 & 0.21 & 0.03 & 11 & 0.23 \\
\hline 20 & 1 & -16.2988 & -71.407 & 89 & 0.089 & 2.2 & 0.20 & 0.00 & 0.2 & 0.20 \\
\hline 21 & 2 & -17.025 & -70.559 & 227 & 0.227 & 33 & 7.49 & 1.02 & 12 & 8.50 \\
\hline 22 & 2 & -17.083 & -70.468 & 104 & 0.104 & 12 & 1.25 & 0.16 & 11.7 & 1.37 \\
\hline 23 & 2 & -17.053 & -70.348 & 62 & 0.062 & 8.9 & 0.55 & 0.07 & 10.9 & 0.64 \\
\hline 24 & 2 & -16.751 & -70.616 & 88 & 0.088 & 3 & 0.26 & 0.01 & 3.2 & 0.28 \\
\hline 25 & 2 & -17.483 & -69.850 & 55 & 0.055 & 1.4 & 0.08 & 0.01 & 6.5 & 0.08 \\
\hline 26 & 2 & -18.311 & -68.809 & 25 & 0.025 & 2.9 & 0.07 & 0.02 & 18 & 0.09 \\
\hline 27 & 2 & -17.079 & -69.996 & 45 & 0.045 & 0.66 & 0.03 & 0.01 & 14 & 0.04 \\
\hline 28 & 2 & -17.144 & -70.101 & 7 & 0.007 & 4.4 & 0.03 & 0.00 & 10.5 & 0.03 \\
\hline 29 & 2 & -17.322 & -69.687 & 28 & 0.028 & 4 & 0.11 & 0.01 & 8.5 & 0.12 \\
\hline 30 & 2 & -16.888 & -69.774 & 86 & 0.086 & 3.5 & 0.30 & 0.07 & 19 & 0.37 \\
\hline 31 & 2 & -17.632 & -69.799 & 26 & 0.026 & 1.4 & 0.04 & 0.00 & 9 & 0.04 \\
\hline 32 & 2 & -18.721 & -68.962 & 46 & 0.046 & 0.4 & 0.02 & 0.00 & 2.9 & 0.03 \\
\hline 33 & 3 & -19.137 & -68.524 & 74 & 0.074 & 1.7 & 0.13 & 0.00 & 1.4 & 0.14 \\
\hline 34 & 3 & -19.146 & -68.696 & 42 & 0.042 & 8.4 & 0.35 & 0.02 & 5.4 & 0.37 \\
\hline 35 & 3 & -19.321 & -68.297 & 48 & 0.048 & 2.7 & 0.13 & 0.02 & 13.2 & 0.15 \\
\hline 36 & 3 & -21.307 & -68.183 & 60 & 0.060 & 3.9 & 0.23 & 0.01 & 3.9 & 0.23 \\
\hline 37 & 3 & -22.558 & -67.851 & 41 & 0.041 & 3.3 & 0.14 & 0.01 & 9.2 & 0.15 \\
\hline 38 & 3 & -19.742 & -68.688 & 79 & 0.079 & 3 & 0.24 & 0.03 & 11.3 & 0.27 \\
\hline 39 & 3 & -20.029 & -68.625 & 91 & 0.091 & 11.2 & 1.01 & 0.12 & 10.9 & 1.14 \\
\hline 40 & 3 & -19.9 & -68.893 & 74 & 0.074 & 8.1 & 0.60 & 0.10 & 14.8 & 0.70 \\
\hline 41 & 3 & -19.981 & -68.696 & 28 & 0.028 & 1.2 & 0.03 & 0.01 & 16.1 & 0.04 \\
\hline 42 & 3 & -20.859 & -68.2 & 37 & 0.037 & 8.5 & 0.31 & 0.03 & 8.5 & 0.34 \\
\hline 43 & 3 & 20.969 & -68.16 & 27 & 0.027 & 0.6 & 0.02 & 0.00 & 14 & 0.02 \\
\hline 44 & 3 & -21.778 & -68.242 & 62 & 0.062 & 3.4 & 0.21 & 0.02 & 9.8 & 0.23 \\
\hline 45 & 3 & -21.579 & -68.26 & 24 & 0.024 & 1.5 & 0.04 & 0.00 & 8.4 & 0.04 \\
\hline 46 & 3 & -21.188 & -68.603 & 25 & 0.025 & 0.21 & 0.01 & 0.00 & 1.3 & 0.01 \\
\hline 47 & 3 & -21.224 & -67.607 & 111 & 0.111 & 6.1 & 0.67 & 0.09 & 11.6 & 0.78 \\
\hline 48 & 3 & -22.267 & -67.183 & 57 & 0.057 & 0.65 & 0.04 & 0.00 & 5.6 & 0.04 \\
\hline 49 & 3 & -22.28 & -67.037 & 85 & 0.085 & 5.5 & 0.47 & 0.08 & 14.3 & 0.56 \\
\hline 50 & 3 & -21.88 & -68.398 & 161 & 0.161 & 25.6 & 4.13 & 0.05 & 1.2 & 4.17 \\
\hline 51 & 3 & -22.834 & -67.882 & 62 & 0.062 & 0.73 & 0.05 & 0.00 & 0.9 & 0.06 \\
\hline 52 & 3 & -23.369 & -67.739 & 51 & 0.051 & 1.7 & 0.09 & 0.00 & 3.4 & 0.09 \\
\hline 53 & 3 & -23.685 & -67.601 & 124 & 0.124 & 8.3 & 1.03 & 0.08 & 6.7 & 1.12 \\
\hline 54 & 3 & -23.745 & -67.54 & 75 & 0.075 & 2 & 0.15 & 0.02 & 12.2 & 0.17 \\
\hline 55 & 3 & -24.415 & -67.98 & 111 & 0.111 & 18.6 & 2.06 & 0.39 & 15.9 & 2.45 \\
\hline 56 & 3 & -24.207 & -68.066 & 65 & 0.065 & 7.9 & 0.51 & 0.08 & 12.8 & 0.59 \\
\hline 57 & 3 & -24.715 & -68.547 & 97 & 0.097 & 2.4 & 0.23 & 0.01 & 2.1 & 0.24 \\
\hline 58 & 3 & -25.089 & -68.365 & 58 & 0.058 & 4.4 & 0.26 & 0.03 & 11.2 & 0.29 \\
\hline 59 & 3 & -25.161 & -68.511 & 82 & 0.082 & 7.6 & 0.63 & 0.01 & 2.2 & 0.64 \\
\hline 60 & 3 & -25.237 & -68.582 & 73 & 0.073 & 1.5 & 0.11 & 0.00 & 1.4 & 0.11 \\
\hline Average & & & & & & 6.20 & 0.61 & & & 0.67 \\
\hline Median & & & & & & 3.90 & 0.24 & & & 0.24 \\
\hline Min & & & & & & 0.21 & 0.01 & & & 0.01 \\
\hline Max & & & & & & 33.00 & 7.49 & & & 8.50 \\
\hline Std. Dev. & & & & & & 6.68 & 1.15 & & & 1.28 \\
\hline
\end{tabular}


Chapter 2 - Constraints on P-T conditions of crystallization and rates of magma formation before and after crustal thickening in the Central Andes 
Chapter 2 - Constraints on P-T conditions of crystallization and rates of magma formation before and after crustal thickening in the Central Andes

\subsubsection{Conditions of the final stage of the magmatic evolution}

\subsubsection{Thermometry}

Comparison of thermometry results between the sample groups should be aided by the fact that wholerock compositions are similar. To further assure comparability, temperatures were estimated from crystal core and rim composition. Additionally, using 7 thermometers for different minerals should acquire representative crystallization temperatures. These results were subsequently compared with MELTS modeled crystallization temperatures. Table 7 compares MELTS data with geothermometry results. With an average difference of $9{ }^{\circ} \mathrm{C}$ comparing results MELTS with clinopyroxene-liquid thermometry, $15{ }^{\circ} \mathrm{C}$ for orthopyroxne - liquid thermometry and $20{ }^{\circ} \mathrm{C}$ for olivine thermometry, the results of both methods show an overall good agreement. An even better agreement between MELTS and geothermometry results are shown in Fig. 13. Here the temperature ranges between the two methods are equivalent. However it must be noted, that the MELTS model was fine tuned by changing water content and pressure to match the thermometers and EMPA mineral data. A consistent dataset is thus provided, although other solutions might be possible as well. On the other hand the results from MELTS, which show equilibrium mineral compositions, show good agreement with measured EMPA mineral compositions as well. However, this only applies for the major element components of clinopyroxene $\left(\mathrm{SiO}_{2}, \mathrm{FeO}, \mathrm{MgO}, \mathrm{CaO}\right)$, orthopyroxene $\left(\mathrm{SiO}_{2}, \mathrm{FeO}, \mathrm{MgO}\right)$ and olivine $\left(\mathrm{SiO}_{2}, \mathrm{MgO}, \mathrm{FeO}\right)$ (Fig. 15). The good agreement of MELTS with the thermometry data, hygrometer and EMPA mineral data suggests that MELTS gives a good overall representation of the crystallization conditions.

Calculated crystallization temperatures results for Miocene and Pliocene/Quaternary samples are shown in Fig 13. As expected, the most mafic samples from Mio-50 have the highest crystallization temperatures. Olivine crystallizes first at temperatures ranging between 1058 and $1225{ }^{\circ} \mathrm{C}$, followed by clinopyroxenes $1037-1180{ }^{\circ} \mathrm{C}$, orthopyroxenes $1030-1169^{\circ} \mathrm{C}$ and oxides with cooling termperatures between $734-876{ }^{\circ} \mathrm{C}$ (oxides tend to re-equilibrate during cooling). Plio-50 show slightly lower average temperatures $\left(<8{ }^{\circ} \mathrm{C}\right)$, however these are insignificant when taking the thermometry errors into account. Plio-50 crystallization temperatures range between $1125-1156{ }^{\circ} \mathrm{C}$ for olivine's followed by clinopyroxenes between $982-1121^{\circ} \mathrm{C}$.

Thermometry data from Mio-55 gave temperatures of olivine $1040-1115{ }^{\circ} \mathrm{C}$, clinopyroxenes between $982-1121{ }^{\circ} \mathrm{C}$ and orthopyroxenes $1010-1093{ }^{\circ} \mathrm{C}$. Plio-55 of Quaternary age with similar $\mathrm{SiO}_{2}$ as Mio-55 unexpectedly yield average crystallization temperatures for olivine, clino- and orthopyroxenes that fall between Mio-50 and 55: $1122{ }^{\circ} \mathrm{C}, 1090{ }^{\circ} \mathrm{C}$, and $1080{ }^{\circ} \mathrm{C}$ for olivine, clinoand orthopyroxene thermometry respectively. At lower temperatures, two pyroxenes and amphiboleplagioclase are more or less equivalent to those of Mio-55. However Fig. 11 displays similar overall temperature ranges for Mio-55 and Plio-55. Comparing temperatures of Mio-60 to Plio-60, which is slightly higher in silica content, are all more or less similar as well. Fig. 13 shows the wide 
Chapter 2 - Constraints on P-T conditions of crystallization and rates of magma formation before and after crustal thickening in the Central Andes

crystallization temperature variation within each group, nevertheless the Miocene and Pliocene/Quaternary samples show a clear pattern of differentiation, with respect to temperature and silica content, from the most mafic (Mio, Plio-50) to the most felsic samples (Mio, Plio-60) due to crystal fractionation processes.

Despite similar temperatures there is one big difference between the Miocene and Pliocene magmas and that is amphibole, being more abundant for Pliocene/Quaternary samples at the same silica content. Since amphibole crystallizes at relative at low temperatures $\left(850-950{ }^{\circ} \mathrm{C}\right)$, the system during Pliocene/Quaternary appears to crystallize later at lower temperatures much more than throughout the Miocene. This can be confirmed in the petrography; more crystal rich and larger phenocrysts. This holds except for the oxide thermometry temperatures, due to fast diffusion of $\mathrm{Fe}$ and Ti at low temperatures (Freer and Hauptman, 1978) gives therefore equilibrium temperatures at final cooling.

A closer look at the thermometry data of cpx-liq and opx-liq to $2 p x$ together with ol-cpx shows particular inaccurate temperatures. When comparing cpx-liq and opx-liq to the $2 \mathrm{px}$ the temperature difference is about $100{ }^{\circ} \mathrm{C}$ (higher temperatures for the thermometers using liquid compositions). The same holds for ol-cpx and ol-liq (higher temperatures for ol-cpx). It is likely that liquid compositions are less accurate, since they are calculated compositions by mass balance and modelled by MELTS (both methods give similar liquid compositions, and by implication crystallization results) rather than microprobe analyzed liquid compositions, 2 mineral phases is therefore more reliable. Comparing temperatures obtained from liquid compositions modelled by MELTS and calculated by mass balance are within the error of the applied thermometer. Since the temperatures between the mineral phases are different for the ol-cpx, ol-liquid and 2 px thermometers (Fig. 13), it is likely that olivine and clinopyroxene are not in equilibrium with each other and show therefore high ol-cpx temperatures. Besides it is also important to look at diffusion rates. Diffusion rates for olivine are indeed higher than clinopyroxene (Chakraborty, 2010; Cherniak, 2010), suggesting that the ol-cpx temperatures are influenced by clinopyroxene. This might explain the higher temperatures present for the ol-cpx thermometer compared to the ol-liquid thermometers.

The main difference with the $2 \mathrm{px}$ and the cpx-liq and the opx-liquid thermometers is the late crystallization of orthopyroxene (Grove et al., 1982), explaining the lower temperatures for the $2 \mathrm{px}$ thermometer. It is thus extremely essential to explore at the diffusion rates before interpreting thermometry results. Furthermore no significant temperature variations were observed for crystal core - rim data pairs for different pyroxene growth stages of one sample. 
Chapter 2 - Constraints on P-T conditions of crystallization and rates of magma formation before and after crustal thickening in the Central Andes

Table 7: Calculated average differences between $\mathrm{H}_{2} \mathrm{O}$ data from hygrometer (Lange et al., 2009) and from MELTS data (weighted by mass). Temperature differences comparing MELT data with geothermometry results. The table indicates an overall good agreement between two models, which is due to the circular approach by MELTS (Fig. 7).

\begin{tabular}{|c|c|c|c|c|c|}
\hline Group & Sample & $\Delta \mathrm{wt} \%(\mathrm{Plg}-\mathrm{MELTS})$ & $\Delta \mathrm{T}(\mathrm{Cpx} /$ liq-MELTS $)$ & $\Delta \mathrm{T}(\mathrm{Opx} / \mathrm{liq}-\mathrm{MELTS})$ & $\Delta \mathrm{T}(\mathrm{Ol} / \mathrm{liq}-\mathrm{MELTS})$ \\
\hline Mio-50 & BAR-01-87 & 0.10 & 6 & 19 & 20 \\
\hline Mio-50 & BAR-01-80 & 1.06 & 10 & & 0 \\
\hline Mio-50 & BAR-00-20 & 0.58 & 7 & 22 & 14 \\
\hline Mio-50 & MIO-12-41 & 0.40 & 0 & & 13 \\
\hline Mio-50 & MAM-24 & 1.00 & 17 & & 5 \\
\hline Mio-55 & BAR-00-37 & 0.37 & 11 & 17 & 28 \\
\hline Mio-55 & MIO-12-40 & 0.91 & 5 & 1 & \\
\hline Mio-55 & MIO-12-23 & 0.15 & 10 & 5 & 37 \\
\hline Mio-55 & BAR-00-36 & 0.51 & 10 & 6 & \\
\hline Mio-55 & BAR-00-28 & 0.90 & 20 & 2 & 5 \\
\hline Mio-55 & MIO-12-05 & 0.05 & 6 & & \\
\hline Mio-55 & CUM-02 & 0.30 & 10 & 4 & \\
\hline Mio-55 & MIO-12-25 & 0.67 & 3 & & 32 \\
\hline Mio-55 & MIO-12-08 & 0.44 & 6 & & \\
\hline Mio-55 & BAR-00-22 & 0.26 & 1 & 28 & \\
\hline Mio-55 & MAM-11-3 & 0.39 & 39 & 0 & 12 \\
\hline Mio-60 & MIO-12-11 & 0.79 & 4 & 1 & \\
\hline Mio-60 & YAH-00-16 & 0.24 & 3 & 12 & \\
\hline Mio-60 & BAR-02-11 & 0.11 & 6 & 18 & \\
\hline Mio-60 & BAR-01-83 & 0.00 & 4 & 25 & \\
\hline Mio-60 & MIO-12-01 & 0.50 & 8 & 11 & \\
\hline Plio-50 & PAR 225 & 0.4 & 9 & & 32 \\
\hline Plio-50 & ERL-N & 0.24 & 3 & & 39 \\
\hline Plio-50 & ERL-1 & 0.13 & 5 & & 33 \\
\hline Plio-50 & POM125 & 0.96 & 3 & & 14 \\
\hline Plio-50 & CUEV-1 & 0.26 & 5 & & 12 \\
\hline Plio-55 & BAR-00-33 & 0.27 & 7 & & 28 \\
\hline Plio-55 & LAS-07-11 & 0.38 & 6 & 33 & \\
\hline Plio-55 & PAR-03-38 & 0.05 & 9 & 28 & \\
\hline Plio-60 & LAS-07-05 & 0.15 & 12 & 22 & \\
\hline Plio-60 & BAR-00-19 & 0.36 & 7 & 20 & \\
\hline Plio-60 & BAR-00-31 & 0.66 & 3 & 4 & \\
\hline Plio-60 & MIS-99-04 & 0.02 & 7 & 38 & \\
\hline Plio-60 & LAS-07-01 & 0.03 & 26 & 27 & \\
\hline Plio-60 & BAR-00-44 & 0.11 & 3 & 27 & \\
\hline Plio-60 & MIN-02 & 0.20 & 28 & 15 & \\
\hline \multirow[t]{4}{*}{ Plio-60 } & BAR-01-52 & 0.00 & & 0 & \\
\hline & APT-11-rock & 0.45 & 8 & 8 & \\
\hline & $\overline{\text { Average }}$ & 0.38 & 9 & 15 & 20 \\
\hline & Maximum & 1.06 & 39 & 38 & 39 \\
\hline
\end{tabular}


Chapter 2 - Constraints on P-T conditions of crystallization and rates of magma formation before and after crustal thickening in the Central Andes

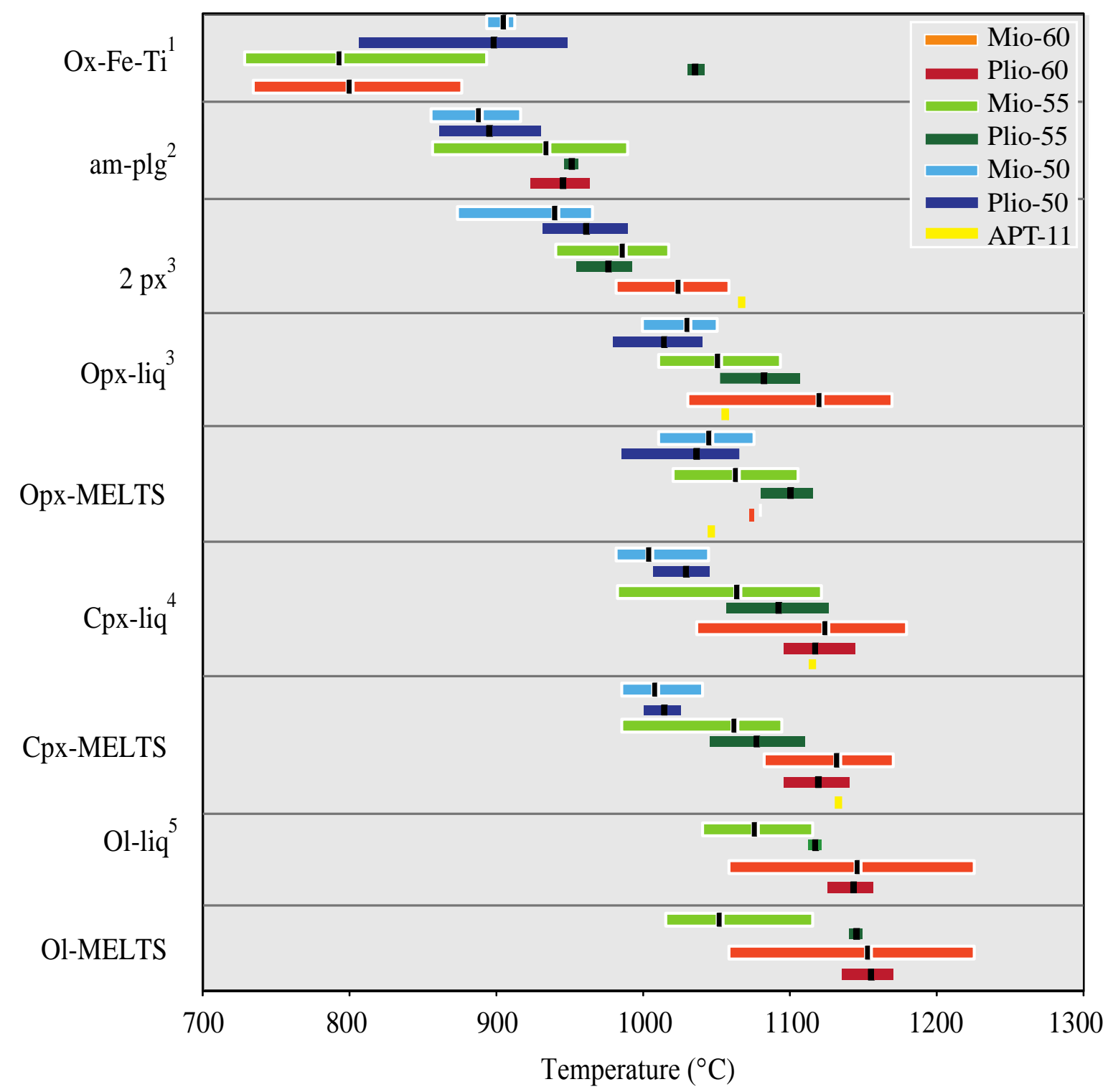

Fig. 13: Calculated crystallization temperature ranges (in ${ }^{\circ} \mathrm{C}$ ) for each group including averages (black line) using various thermometers. (1): Giorsho and Evans (2008), (2): Holland and Blundy (1993), (3): Putirka (2008), (4): Putirka et al., 2003, (5): Putirka et al., 2007.

\subsubsection{Hygrometry and barometry}

The relatively uniform mineral assemblage and composition in all samples as reflected in similar temperatures and thus I expect also similar pre-eruptive crystallization pressures. The validity of 
Chapter 2 - Constraints on P-T conditions of crystallization and rates of magma formation before and after crustal thickening in the Central Andes

different barometers (MELTS, amphibole barometry (Ridolfi and Renzulli, 2012 and Schmidt, 1992), $2 \mathrm{px}$ and $\mathrm{ABS}$ ) has been applied and tested.

Using MELTS an estimate of the crystallization pressures from olivine, clino- and orthopyroxenes between 4 and 0.5 kbars was modelled (Fig. 14). These results were obtained indirectly from MELTS, here pressure and water content was varied until a good fit was found between crystallization temperatures obtained by MELTS and multiple geothermometrical models and analyzed mineral compositions (see above). Furthermore I derived an average $\mathrm{H}_{2} \mathrm{O}$ content of 0.94 wt $\%$ for Mio-50, 2.47 for Mio-55 and 3.0 wt \% for Mio-60 using the hygrometry model of Lange et al., 2009. Water content for the younger Plio-55 group is slightly lower (1.23 wt\%), but no distinction between Mio-50 - Plio-50 and Mio-60 - Plio-60 is observed.

The main problem of MELTS is its inability to model amphiboles, since Margoles parameters for many components are poorly defined. Therefore MELTS has a preference of garnet over amphibole and is MELTS not a representative model to determine the crystallization history of amphiboles. This might also create inaccurate pressures (temperatures and compositions as well) as a consequence of a different crystallization path. Although it must be noted that amphibole crystallizes generally at a late stage thus the consequence of no amphibole crystallization can likely be ignored when considering the crystallization of plagioclase, olivine, cpx and opx.

Besides the shallow crystallization conditions found by MELTS, deeper crystallization conditions are identified by using amphibole barometry (Schmidt, 1992) between 4 kbar and 8 kbar. When ignoring the two outliers, the pressure range becomes much smaller (5.9 to $6.6 \mathrm{kbar}$ ) (see Fig. 134). Since the Al-in-Hornblende barometer is for dacitic compositions and the data can be inaccurate it is therefore important to explore other barometers. Surprisingly, pressure data after Ridolfi and Renzulli (2012) lies exactly between MELTS and Al-in-Hornblende pressures (Schmidt, 1992), with a relatively narrow range from 3 to 5 kbar (Fig. 14). It is thus unclear so far at what depth amphibole crystallizes. From both barometers is seems that only the amphiboles crystallize at much deeper depths than olivines, clino- and orthopyroxenes and oxides crystals obtained pressures by MELTS, however there is no proof that these amphiboles are xenocrysts. Besides the amphibole phenocrysts with thick reaction rims results during magma ascent, especially slower decompression rates results in amphiboles with progressively thicker reaction rims (Rutherford and Hill, 1993).

Interestingly, 2 px pressures after the model of Putirka (2008) indicates much higher pressures between 9 and $3 \mathrm{kbar}$ and cover a much longer range than MELTS for the two pairs of pyroxenes. Comparing all four applied barometry methods (Fig. 14) suggests at least one of the three barometers is inaccurate. We shall discuss each of these barometers in turn in the discussion section. 


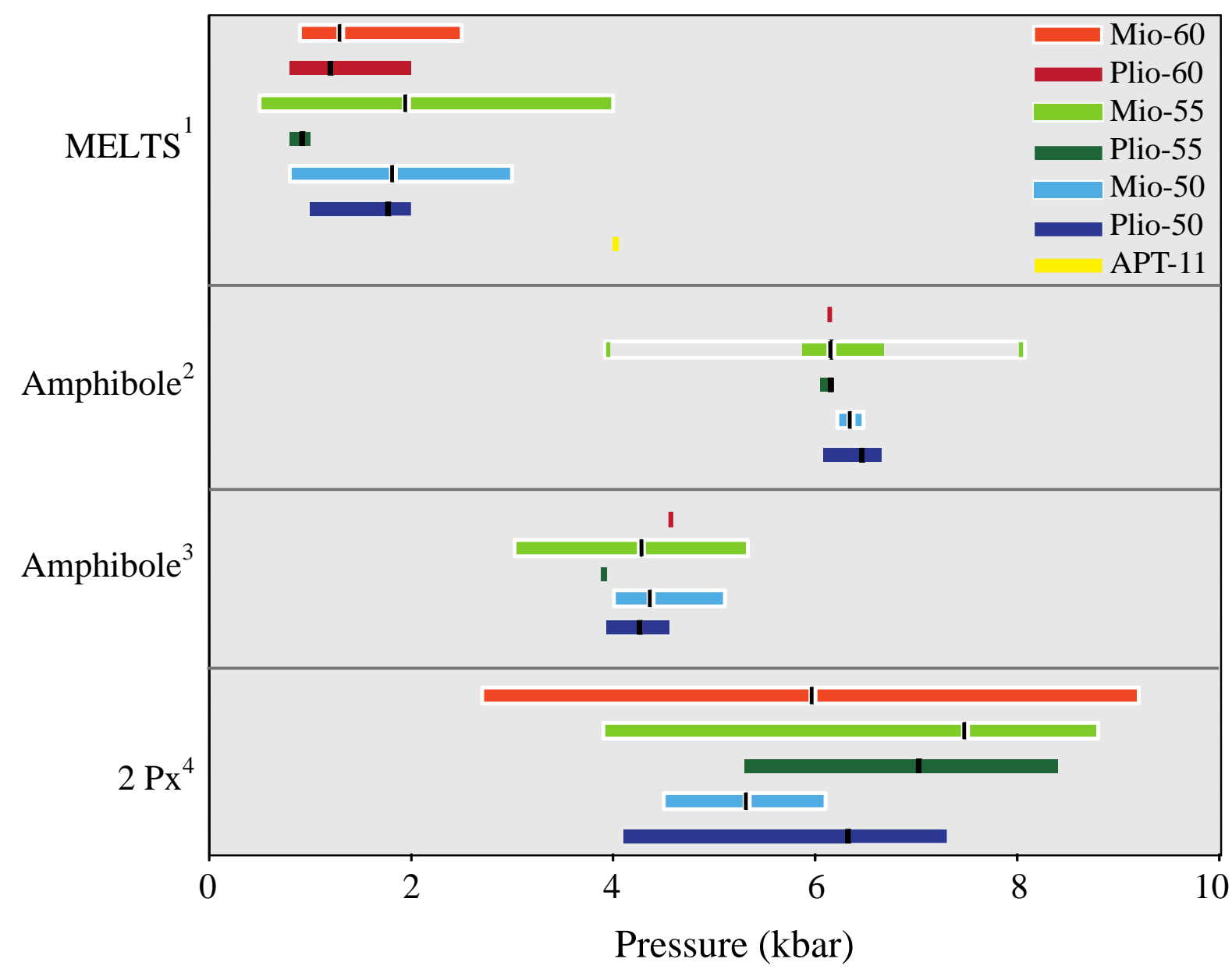

Fig. 14: Range of pressure estimates including averages (black line) in kbar for each group using different barometers representing two different magmatic reservoirs. (1): MELTS (Gualda et al., 2012) (2): Al-in-Hornblende (Schmidt, 1992). Two Mio-55 samples fall outside the range shown by the two outliers (3): amphibole (Ridolfi and Renzulli, 2012) (4): 2 pyroxene (Putirka, 2008)

\subsubsection{APT-11}

In order to characterize a distinct magmatic regime I included one Late Jurassic (APT-11) sample $\left(\mathrm{SiO}_{2}\right.$ of $\left.54.58 \mathrm{wt} \%\right)$, which is a pillow basaltic andesite formed in a extensional subaquatic tectonic setting, formed underneath a thin crust in the Central Andes. Due to the different magmatic regime I expect, for this sample, a different P-T path as for the Miocene and Pliocene/Quaternary lavas.

Still, the obtained temperatures $1122^{\circ} \mathrm{C}, 1053{ }^{\circ} \mathrm{C}$ for cpx-liquid (Putirka et al., 2003) and opxliquid (Putirka, 2008) thermometers and $1064{ }^{\circ} \mathrm{C}$ for the two pyroxene thermometer, are all relatively similar to the mafic Miocene samples (Mio-55) (Fig.14). Notable is that the $\mathrm{H}_{2} \mathrm{O}$ content, using the hygrometer (Lange et al., 2009) of $2.0 \mathrm{wt} \%$ is much higher than any given sample from Mio-50, as is the much higher modeled pressure of 4 kbar. 
Chapter 2 - Constraints on P-T conditions of crystallization and rates of magma formation before and after crustal thickening in the Central Andes

Miocene samples
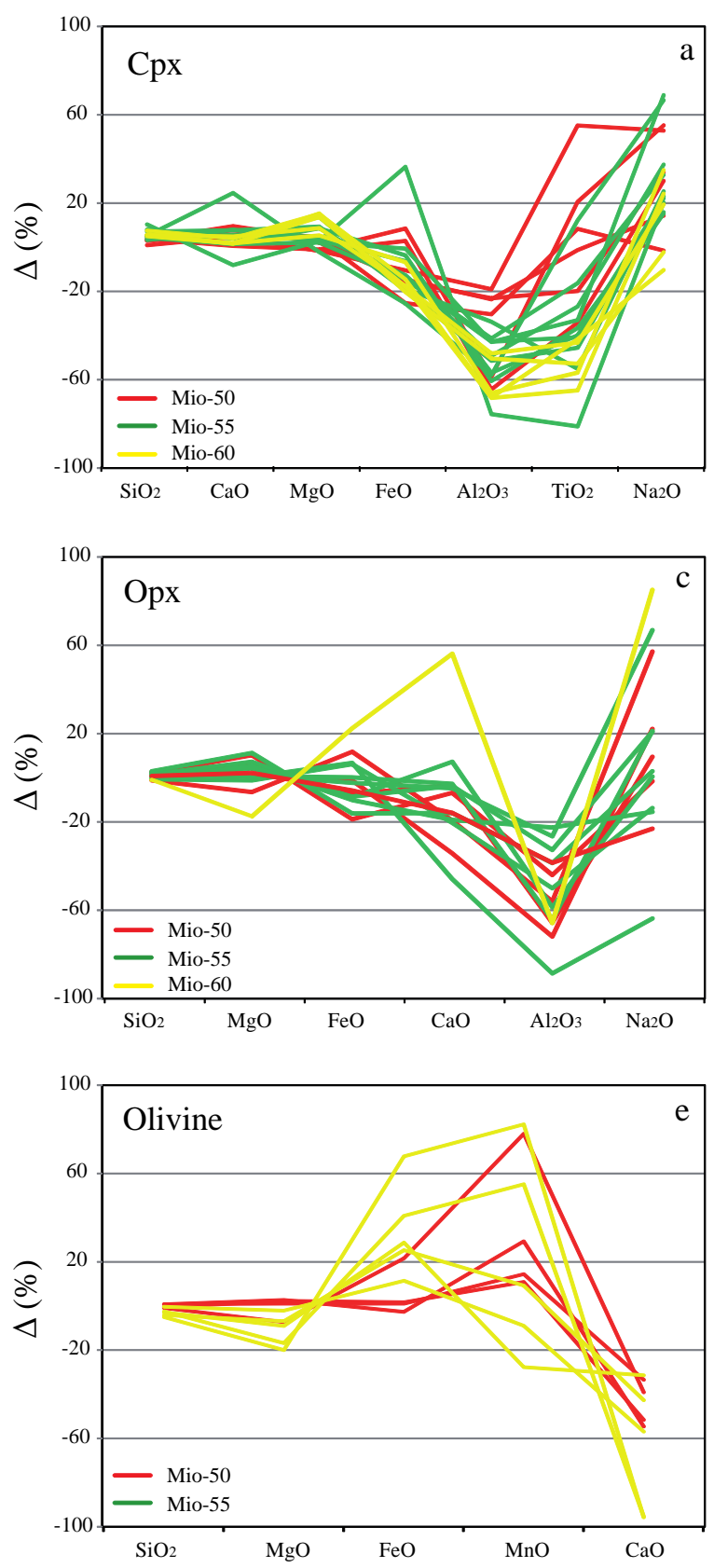

Pliocene/Quaternary samples
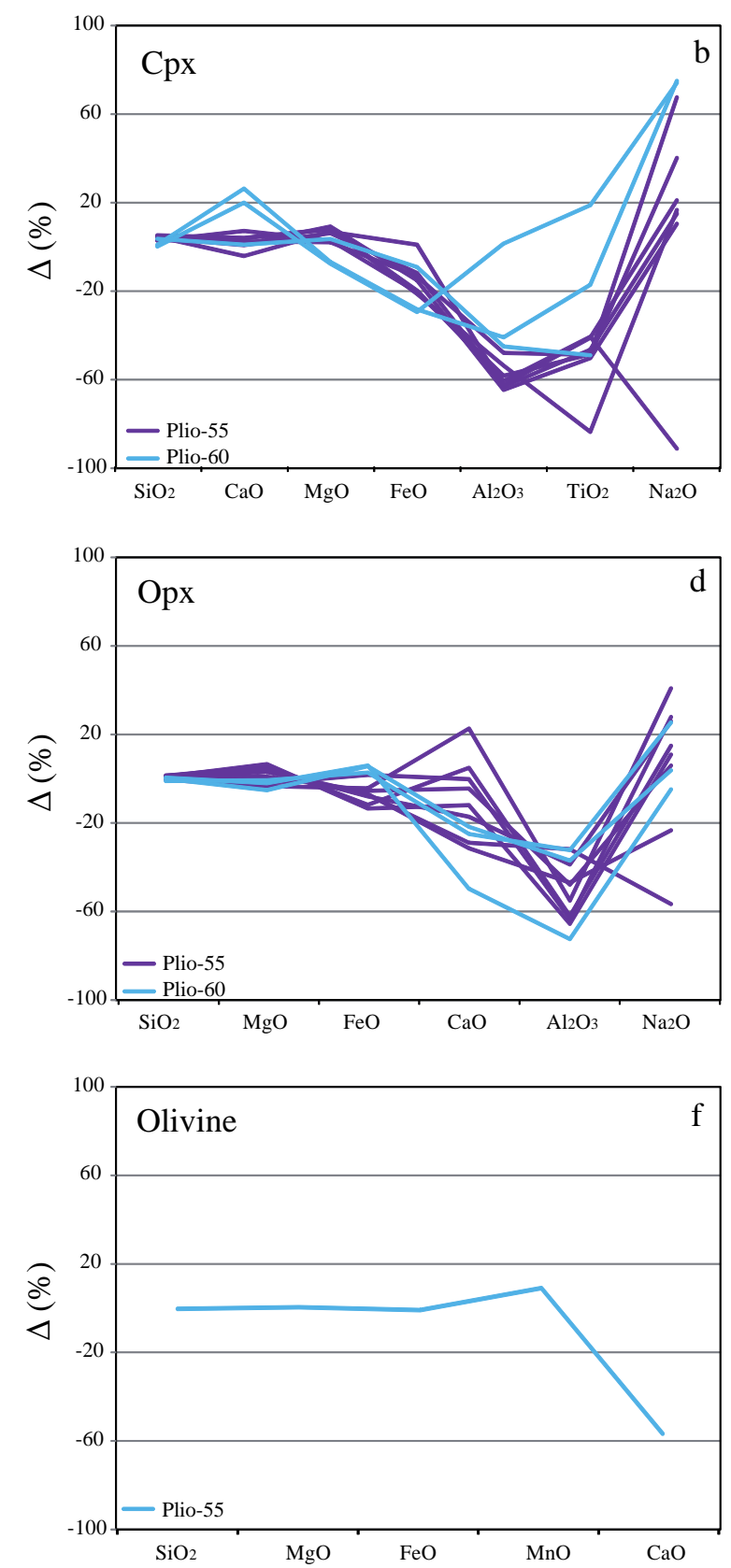

Fig.15: Calculated average difference for clinopyroxene (a,b) orthopyroxene (c,d) and olivine (e,f) compositions between EMPA measurements and opx from MELT data (weighted by mass differences taken into calculation). The figure indicates an overall good agreement between modelled major element compositions and measured compositions. However, this only applies for the major element components of clinopyroxene $\left(\mathrm{SiO}_{2}, \mathrm{FeO}, \mathrm{MgO}, \mathrm{CaO}\right)$, orthopyroxene $\left(\mathrm{SiO}_{2}, \mathrm{FeO}, \mathrm{MgO}\right)$ and olivine $\left(\mathrm{SiO}_{2}, \mathrm{MgO}, \mathrm{FeO}\right)$ 
Chapter 2 - Constraints on P-T conditions of crystallization and rates of magma formation before and after crustal thickening in the Central Andes

\subsubsection{Plagioclase CSD and compositions}

As described above, the Miocene and Pliocene/Quaternary groups show no pronounced crystallization temperature distinctions even for samples with different major element composition $\left(\mathrm{SiO}_{2}\right.$ from $52-62$ wt. \%). This might be because: 1$)$ there are simply no temperature variations present or 2) magma mixing is extremely effective in producing similar final products during late stages of magma evolution or (3) crystallization of mineral pairs occurs at typical temperatures determined by phase relations. Plagioclase crystal size distribution (CSD) and compositions must resolve these two options.

CSDs (Higgins, 2000) were performed on three to four samples for each group. Nearly all samples analyzed for crystal size distribution show similar characteristics and produce concave upward curved plots (Fig. 16). Instead of a linear CSD, the distributions of all samples show pronounced kinks in slopes at different steps in length. Two different kinks can be recognized, one at around 400-600 $\mu \mathrm{m}$ and the second at $1200 \mu \mathrm{m}$. Such kinked CSD's are commonly considered to result from magma mixing (Higgins, 2000). In comparison to the Miocene and the Pliocene andesites, which look quite similar; the Pliocene samples have significantly smaller amounts of crystals $(<800$ $\mu \mathrm{m}$, Fig. 16f). Beyond that, for crystal sizes larger than $800 \mu \mathrm{m}$, no distinction can be found between the Miocene and the Pliocene samples, showing typical magmatic phenocrysts of andesitic composition with a maximal crystal size of $3.5 \mathrm{~mm}$. Even though crystal sizes of the analyzed samples never exceed $3.5 \mathrm{~mm}$, larger phenocrysts are present in some of the lavas in the CVZ, but this is rarely the case. One well-known example of volcanic K-feldspar megacrysts up to $10 \mathrm{~cm}$ long occur in some of the dacitic lavas of Taapaca volcano, Chile (Clavero et al., 2004; Zellmer and Clavero, 2006; Freymuth, 2006) and provides therefore reference as a distinct petrographic endmember. In contrast, the El Misti lava samples provide a representative distinct endmember of aphyric lava (Wegner, 2002) (Fig. 16f).

The interpretation of magma mixing is supported by differences in plagioclase morphology and composition. A decrease of $\mathrm{Fe}_{\text {melt }}$ that is correlated with anorthite contents indicates that the plagioclase crystallized from a more Fe depleted (i.e. evolved) melt. Multiple episodes of crystal transfer from mafic to silicic melts and back are reflected by the individual growth zones, in- and decrease in iron and anorthite content recording the succession of events which reflect chemical differences/changes within the magmatic system, due to recharge of mafic magma, mixing and mingling of different end members and/or crustal contamination. However, small rhythmic zones could also be a result of diffusion - boundary layer processes.

To see if the compositions that mixed in the magmatic system crystallized from the same or different end members $\mathrm{Fe}_{\text {melt }}$ is plotted against anorthite content in Fig. 17. Plagioclase phenocrysts were divided into four populations based on their CSDs: Plg > $1200 \mu \mathrm{m}, \mathrm{Plg} 600-1200 \mu \mathrm{m}$, Plg < $600 \mu \mathrm{m}$ and $\mathrm{Plg}>1220 \mu \mathrm{m}$ rim. 
Chapter 2 - Constraints on P-T conditions of crystallization and rates of magma formation before and after crustal thickening in the Central Andes

Figure 17 show that $\mathrm{Fe}_{\text {melt }}$ concentrations in general decrease with decreasing anorthite content indicating that anorthite-rich compositions crystallized from more mafic melts. In addition, the maximum anorthite content decreases with increasing silica content within the melt, however this seems to be only the case for the Miocene samples. Moreover, when comparing all 15 analyzed samples there seem to be three trends present. Represented by Mam-24 and Mio-12-01, 1) Plg > 1200 $\mu \mathrm{m}$ crystallizes first, while crystal fractionation takes place both $\mathrm{Fe}_{\text {melt }}$ and anorthite content decreases. In a later stage Plg $<600 \mu \mathrm{m}$ and the Plg $>1200 \mu \mathrm{m}$ rim crystallizes. Magma mixing up to this point is not a dominant process. However the matrix composition, which has been determined by mass balance calculations of the bulk rock, indicates a more mafic composition. This leads to believe a mafic input and likely eruption took place, without any further crystallization.

2) These samples (MIO-12-39, Mio-12-41, MAM-14, MIO-12-40, BAR-00-19, LAS-07-05 and MIS-99-04) all show a clear crystal fractionation trend (decrease of anorthite content) although in contrast to 1) Plg >1200 $\mu \mathrm{m}$ does not crystallize first, but it rather seems all plagioclases crystallizes from different hybrid magmas and demonstrates that mixing of mafic and felsic magmas resulted in the juxtaposition of the two or more different plagioclases. 3) Within this group all plagioclases (Mam-11-3, Bar-01-83, YAH-00-16, BAR-00-33, LAS-07-11 and PAR-03-38) crystallized from similar hybrid magmas since there is limited variability in plagioclase composition. Similar to 1), matrix compositions show a mafic input after crystallization stops. 
Chapter 2 - Constraints on P-T conditions of crystallization and rates of magma formation before and after crustal thickening in the Central Andes
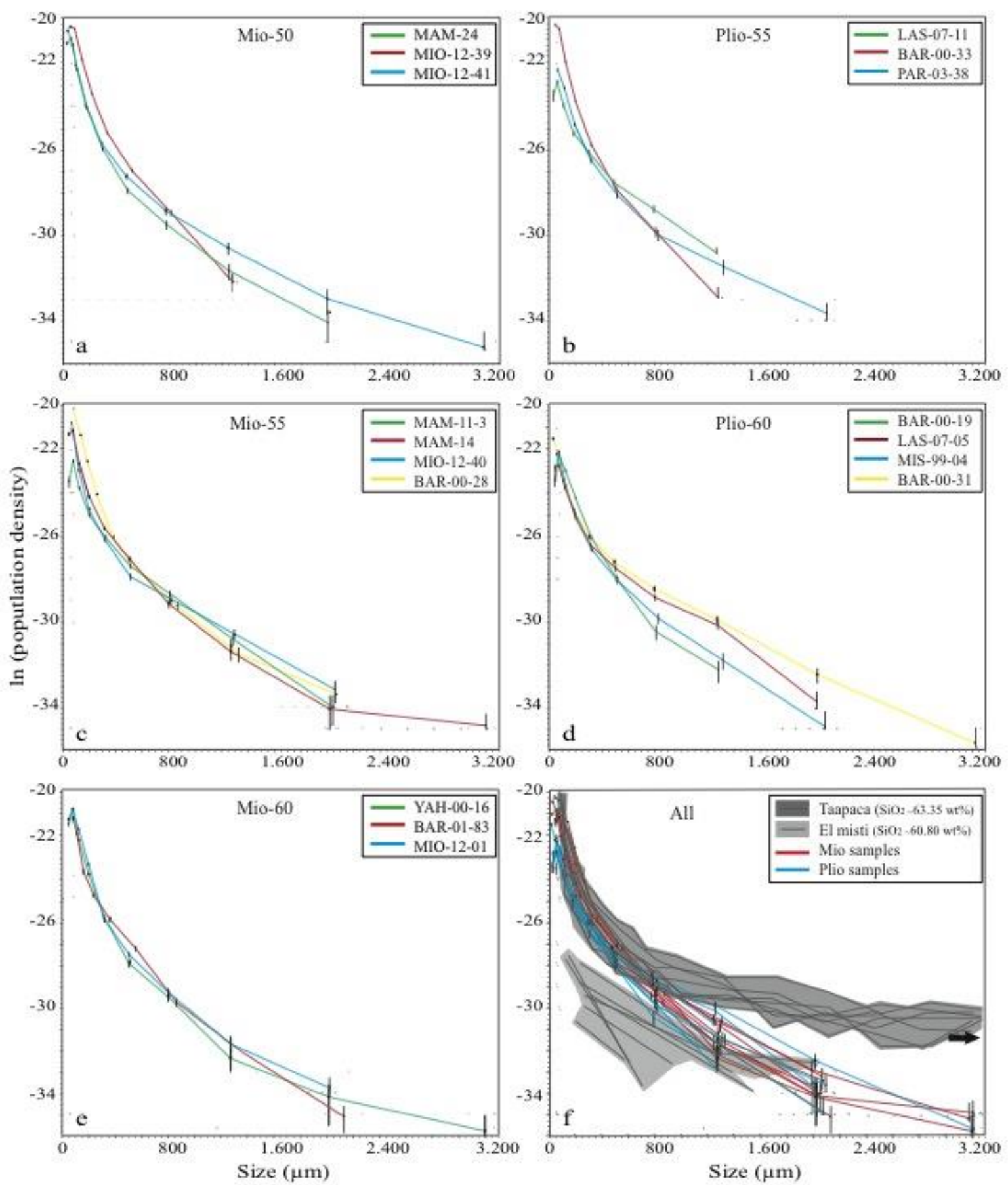

Fig. 16: Graphical display of the crystal size distributions of the five different analyzed groups on a classical diagram of $\ln$ (population density) versus crystal size. The grey areas reference to the petrographic endmembers dark grey: Taapaca megacrystic dacites and light grey: monotonous El Misti andesites. Data Taapaca and El Misti from (Freymuth, 2006 and Wegner, 2002) 
Chapter 2 - Constraints on P-T conditions of crystallization and rates of magma formation before and after crustal thickening in the Central Andes
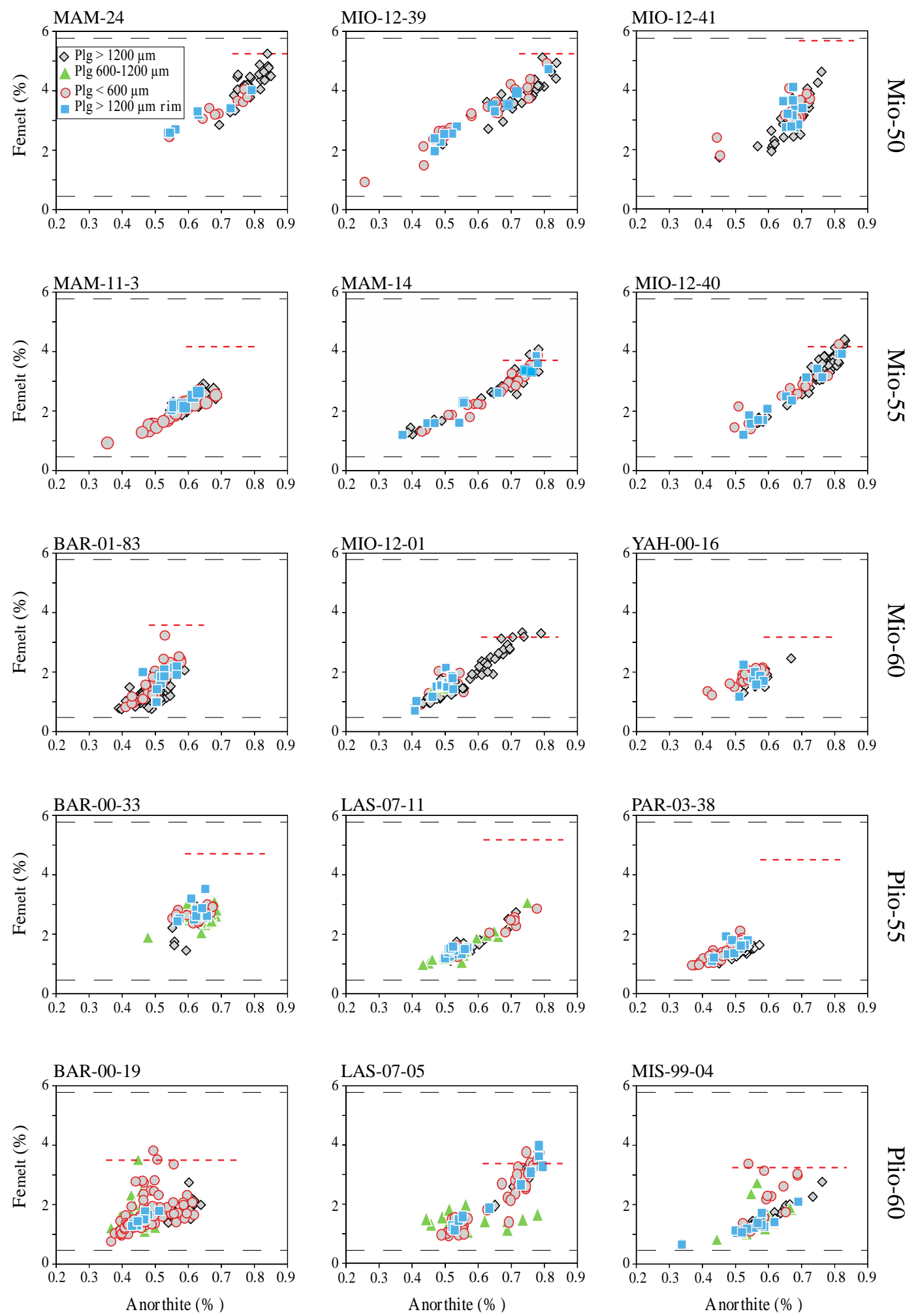

Fig. 17: Equilibrium concentrations of iron in melt from which plagioclase growth zones crystallized. Analyses were done in representative portions of core to rim. The melt compositions were calculated according to the method of Bindeman et al. (1997) Plagioclase phenocrysts have been divided into four populations representing the groups found by CSD; Plg > 1200 $\mu \mathrm{m}, \mathrm{Plg} 600-1200 \mu \mathrm{m}, \mathrm{Plg}<600 \mu \mathrm{m}$ and Plg $>1220 \mu \mathrm{m}$ rim. End member are represented by the dashed black lines and the matrix composition is represented by the red dashed line 
Chapter 2 - Constraints on P-T conditions of crystallization and rates of magma formation before and after crustal thickening in the Central Andes

\subsection{Discussion}

In the introduction of this chapter I explained the transition between two different magmatic regimes could be a result of (1) a change in the mantle melting regime from decompression to flux melting, (2) different P-T-regimes of magma evolution within the crust as a function of crustal thickness, and (3) different rates in magma production and effusion. Each of these hypotheses will be evaluated based on the obtained results.

\subsubsection{Formation of homogeneous intermediate magmas}

In the introduction I have argued that a change in the mantle melting regime from decompression melting leading to Miocene magmas which are hot and dry to flux melting during the Pliocene to Quaternary with higher $\mathrm{H}_{2} \mathrm{O}$ abundance and lower temperature magmas may be the principal process explaining the observed differences in eruptive style. However this hypothesis is not supported by our data. When I take all obtained results from the thermometry and hygrometry, the multiple thermometry techniques do not distinguish between the Miocene and Pliocene/Quaternary groups of similar composition. This suggests that any possible difference in the melting mechanism between Miocene and Pliocene magmas and thus a change in mantle melting regime cannot be discriminated by the P-T conditions of crystallization of the observed phenocrysts.

To test the second hypothesis of different P-T-regimes of magma evolution within the crust as a function of crustal thickness, the APT-11 sample was included. This pillow basalt of Late Jurassic age represents the earliest phase of subduction magmatism in the Andes, which occurred in an extensional arc tectonic environment (Grocott et al., 1994). Here, thick beds of pillow lavas, sheet lavas and tuffs with basaltic to andesitic composition occur within the Morro-Solar and Casma groups and were intruded by the Coastal Batholith in a magmatic episode lasting from the Early Jurassic to the Early Paleogene (Mukasa, 1986; Mukasa and Tilton, 1985). During this time both the crustal thickness and the magmatic regime are not comparable to the Miocene and Pliocene/Quaternary. However, as seen by thermobarometry (Fig. 13) all andesitic temperatures (including APT-11) and pressures (besides amphibole) are rather constant for a given composition. Thus it seems even within a totally different tectonic setting the crystallization conditions appear to be the same for magmas of similar composition. This might be because: 1) there are simply no temperature variations present or 2) magma mixing is extremely effective in producing similar final products during late stages of magma evolution or (3) crystallization of mineral pairs occurs at typical temperatures determined by phase relations. Since magma mixing is a dominant process, among shown by CSD, it might affect the crystallization temperatures, however once phenocrysts crystallize and further cooling occurs, the initial temperatures are frozen into earlier phenocrysts and thus retain their high temperature heritage. Magma mixing should therefore have no influence on the crystallization temperatures. Unless 
Chapter 2 - Constraints on P-T conditions of crystallization and rates of magma formation before and after crustal thickening in the Central Andes

crystallization follows after the mixing, but in that case plagioclase and CSD calculations would show uniform results.

As previously shown by the plagioclase CSDs and compositions, magma the mixing is extremely effective. Figure 18 indicates the andesitic composition is remarkably restricted with $80 \%$ of all samples ranging from 56 to $65 \mathrm{SiO}_{2}$ wt\% emphasizing the possible role of magma mixing in generating intermediate compositions. Reubi and Blundy (2009) have also argued from melt inclusions that the liquids of the intermediate andesitic compositions are actually uncommon in arc volcanic systems, but rather the more mafic and felsic compositions are more frequent (Fig. 18). This leads me to believe that due to the effective mingling and mixing within upper crustal reservoirs, the bimodal (or even trimodal) composition of melts is masked after ascent from the lower crust. The lack of mafic lava samples is, besides magma mixing, a result of density barriers. The reduced abundances at $68 \mathrm{wt} \% \mathrm{SiO}_{2}$ can be explained by the viscosity barrier after differentiation. Due to effective magma mixing processes in the upper crust together with the density and viscosity barriers, only magmas with intermediate compositions are able allowed to erupt. This might also explain similar P-T of crystallization a given andesitic composition.

MELTS, thermometry and hygrometry data represent temperatures and $\mathrm{H}_{2} \mathrm{O}$ contents of well mixed final stage magmas instead of initial melt conditions and are rather independent of tectonic regime and crustal thickness. However, despite of the magma mixing, the depletion of HREE for the Pliocene/Quaternary samples compared to Miocene samples is still captured and can be explained by crustal thickening (Kay et al., 1994, 1996; Mamani et al., 2010). The presence of the same final crystal conditions but differences in rare earth elements suggest that the processes within the deep crust or mantle wedge must be decoupled from the mixing and crystallization processes during the final magma evolution at shallow levels. Besides the lack of a negative Eu anomaly (Fig. 11) even in the more evolved samples with abundant and large plagioclase phenocrysts are not reflecting the deeper and earlier magmatic processes and argues thus for decoupling. However, if the possibility exists that the initial melt condition would have been different in P-T (which cannot be seen) they must have been filtered out during the ascent within the thick crust. 


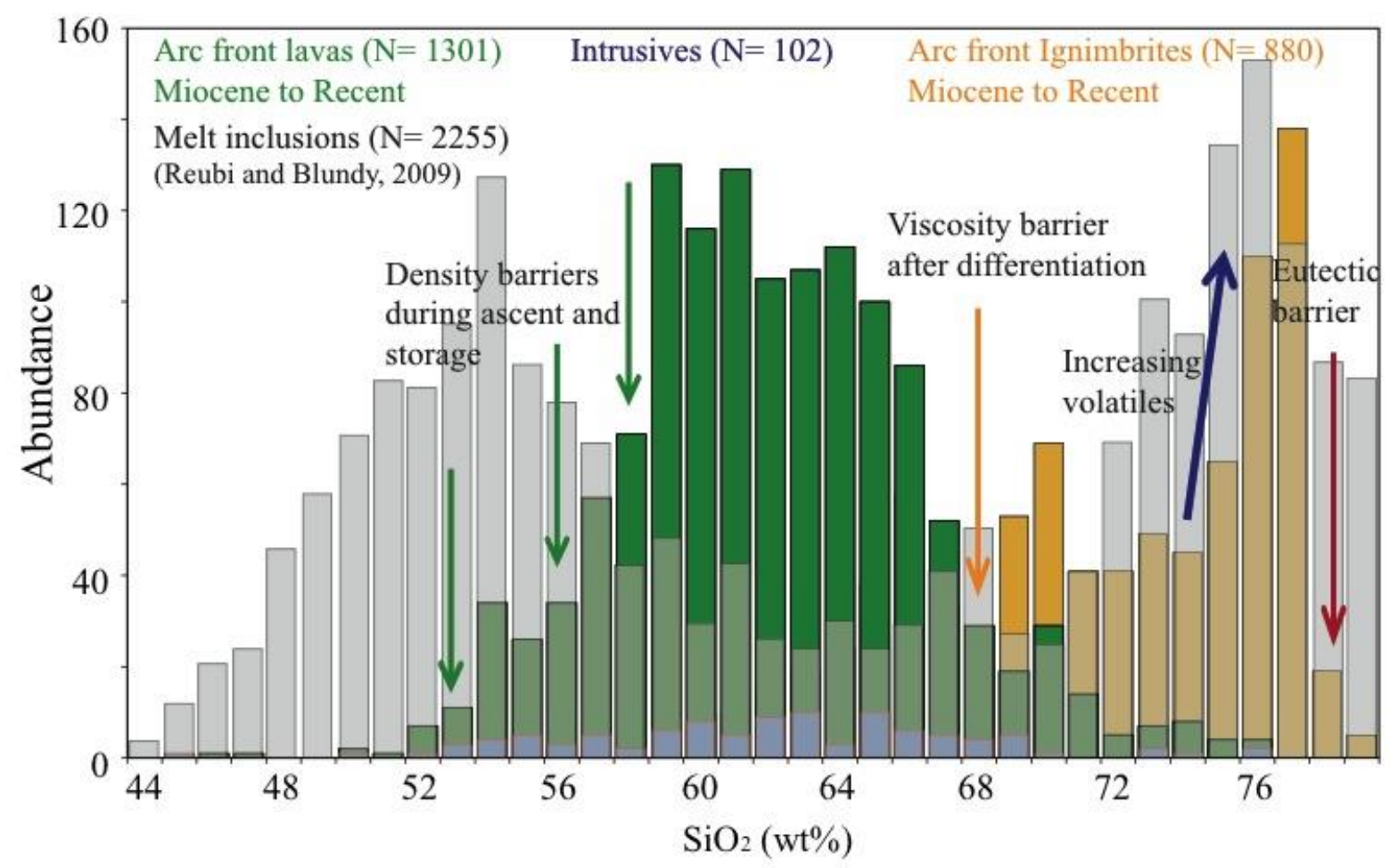

Fig. 18: Frequency histogram showing all Andes database samples including the global melt inclusion compositions in arc magmas from Reubi and Blundy, 2009)

\subsubsection{Magma bodies}

Another topic that must be assessed is the high abundance of amphiboles in many of the Pliocene/Quaternary samples. In order to explain this I must look more carefully into a change of magmatic systems, magma mixing, and magma storage levels.

Previously I have shown that mixing is very effective within the upper crust. Together with barometry (Fig. 19) data, I argue for multiple crystallization levels or even storage levels at different depths where homogenization of the end members takes place.

MELTS barometry data suggest crystallization of olivines, pyroxenes, plagioclases and oxides takes place between 4 and 0.5 kbars, and would indicate very shallow crystallization conditions. As previously mentioned in the results section, a deeper crystallization region might be found by using aluminum in hornblende geobarometry (Schmidt, 1992), at pressures between 6 and $7 \mathrm{kbar}, \sim 22 \mathrm{~km}$ (figures 14 and 19). Although the method of Schmidt (1992) show relative high pressure values of about 6 kbar compared to the Ridolfi and Renzulli 2012 amphibole barometer, with crystallization conditions between 3 to $5 \mathrm{kbar}$. The higher pressures of the $\mathrm{Al}$ in hornblende barometer (Schmidt, 1992) could be due to the lack of the equilibrium caused by the absence of sanidine, quartz, and biotite among other phases, which need to co-crystallize with hornblende for the model. Besides lower pressures have been recorded in Central Andes using amphibole barometry also shown by (Banaszak, 2014). 
Chapter 2 - Constraints on P-T conditions of crystallization and rates of magma formation before and after crustal thickening in the Central Andes

However to complicate the situation even further, when comparing pyroxene pressures obtained from MELTS (Fig. 11) and 2 Px after Putirka (2008) they are highly mismatched (Fig. 14). There are multiple possible explanations for these results: (1) Pressure ranges obtained by MELTS are true and the two px are false (Fig. 19). In this case amphibole crystallizes at higher pressures and with lower temperatures (same for both amphibole barometers) as the plagioclase, olivine, clino and orthopyroxenes and oxides. The low amphibole temperatures $\left(\sim 950^{\circ} \mathrm{C}\right)$ suggests at this crystallization depth the magma must have cooled down after the large ignimbrite eruptions. Subsequently the presence of amphibole phenocrysts within the Pliocene and some Miocene samples demonstrates that some melts stall at $22 \mathrm{~km}$ depth, differentiate and mix further - inserting the amphibole phenocrysts within the hybrid as xenocrysts. This might also explain the higher amphibole abundances within the more differentiated samples (Mio-60 and Plio-60). The amphiboles crystallized thus from a different, older (system cooled down to $950{ }^{\circ} \mathrm{C}$ ) melt as olivine, cpx, opx, and oxides. The higher abundance of amphiboles within the Pliocene and Quaternary samples suggests that the time frame of differentiation and stalling (Fig. 21) become larger and the magmas have more time for crystallization. Miocene eruptive products thus would become more aphyric and contain less amphibole than the PlioceneQuaternary eruptive products.

MELTS barometry data indicated than that the final crystallization of these amphibole bearing magmas took place at between 0.5 and $4.0 \mathrm{kbar}$. The lack of an Eu anomaly (Fig. 11) mentioned above would preclude extensive low pressure plagioclase fractionation and suggests that these magmas ascended comparatively fast from deeper MASH zones without considerable fractionation at shallow crustal levels. One of the issues of these findings, it is questionable that during cooling down and crystallization of the "older" magma only amphibole crystallizes as a phase and/or is inserted as a xenocryst to the "younger" magma. Furthermore, there is no petrographic evidence that the amphiboles are xenocryst. The MELTS model thus needs to treated with care.

(2) Pressure ranges obtained by 2 Px are true and MELTS pressures are false (Fig.19). These results can be explained again by two different (fast and slow) systems. Miocene magmas crystallize at pressures between 9 and 3 kbar. Suggesting crystallization conditions at different depths for each volcano rather than one or two distinct depths. Possibly due to a crustal thickness of approximately 40 $\mathrm{km}$ (rather than 60-70 nowadays) the distance of ascend changed through time. The pathway of the Miocene magmas is thus much easier and therefore also faster. Consequently the system has less time to cool down to temperatures of $950-850{ }^{\circ} \mathrm{C}$ and is therefore unable to crystallize amphibole (Minimum temperature of Miocene system is generally $>950{ }^{\circ} \mathrm{C}$ (Fig.11). An argument against this idea would be that oxides with temperatures of $<900{ }^{\circ} \mathrm{C}$ or similar temperatures as amphiboles (Fig. 13) crystallize from Miocene melt as well. The cause for low calculated temperature in oxides is that they have likely been reset by rapid diffusion while still in the magma reservoir and/or during posteruption cooling (Hammond and Taylor, 1982; Venezky and Rutherford, 1999). Oxide temperatures therefore very likely record eruption temperatures due to the late diffusive closure of Fe-Ti exchange 
Chapter 2 - Constraints on P-T conditions of crystallization and rates of magma formation before and after crustal thickening in the Central Andes

in oxides. Many open questions remain regarding correct pressures; therefore all barometry results need to be interpreted with caution.

Based on ABS modeling the pressure of the slab where the liquid is derived is defined at 35 kbar or $117 \mathrm{~km}$, the melts then ascend to $20 \mathrm{kbar}$ or $70 \mathrm{~km}$ where fluids and melt are continuously flowing into and out of the region. This MASH zone (a zone of melting, assimilation, storage and homogenization) (Hildreth and Moorbath, 1988) is just below the base of the crust this zone would be at $\sim 70 \mathrm{~km}$ depth during the Quaternary just below the MOHO and is consistent with the average value of $70 \mathrm{~km}$ depth (Philips et al., 2012). The MASH zone is a relatively narrow zone in the lowermost crust or mantle-crust transition, where mixing between mantle derived melts and melting of crustal rocks takes place (Hildreth and Moorbath, 1988) and mixes with crustal melts to produce intermediate compositions. The few mafic lava flows found in the Andes can only ascend from this lower crustal zone after assimilation and fractional crystallization has lowered the magmatic density (McMillan et al., 1993). Magmas rose from the MASH zone and accumulated within the weakened upper crust resulting from the increase in convergence rates and subsequently the elevated geotherms.

Despite of the unclear barometry data, the results of the homogenous mineral composition between volcanic rocks of the Miocene and Pliocene/Quaternary, the same $\mathrm{P}-\mathrm{T}$ assemblage were obtained for the equilibrium of the mineral assemblages. Subsequently no deepening in the level of final crystallization is registered, despite the increase of crustal thickness. So it is possible that the depth of the magma chambers might have been controlled by the position of the brittle-ductile transition in the crust since the shortening takes mostly place at the lower curst (Litvak and Poma, 2014). 


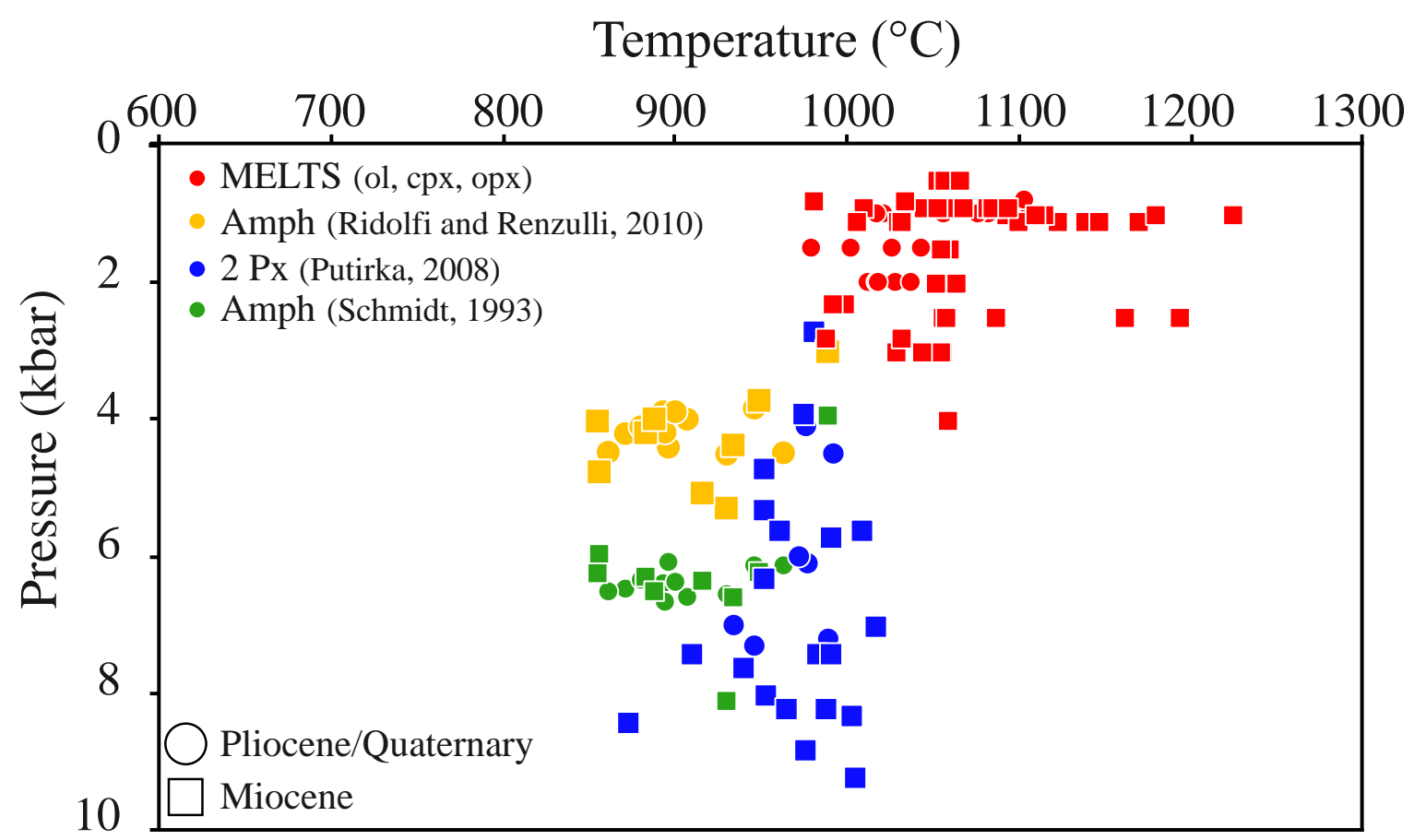

Fig. 19: P-T diagram showing all obtained pressure data for Miocene (Square) and Pliocene/Quaternary samples (circles). Unlike might be indicted by this figure, it is important to keep in mind, amphiboles are rare for Miocene magmas. There are 2 possible explanations for the wide range of obtained pressures. Option 1: Low amphibole temperatures $\left(\sim 950{ }^{\circ} \mathrm{C}\right)$ at $6 \mathrm{kbar}$ or 4 kbar suggest a magmatic body which is much older and cooled down after large ignimbrite eruptions. Buoyant melts from the MASH zone accumulate, merge, mix and differentiate further at this accumulate, inserting much older amphiboles within the magma as xenocrysts at $\sim 6$ kbar. This would be the slow process, a fast system (Miocene magmas) which bypasses the $\sim 20 \mathrm{~km}$ zone and rise straight to a much shallower reservoir, shown by MELTS obtained pressures. Option 2: Fast system (Miocene) crystallization takes place between 3 and 9 kbar (2px). Slow system (Pliocene/Quaternary) crystallizes within the pressure range however the slow system has time to cool and crystallize amphibole at 6 kbar or 4 kbar.

\subsubsection{A change in effusion rate}

Besides composition, volatile content, and crystal and bubble content, temperature is one of the main factors in controlling the viscosity. As stated above, the crystallization temperatures and pressures are very similar for the Miocene lava shields and the Pliocene/Quaternary stratovolcanoes. The same holds for the $\mathrm{H}_{2} \mathrm{O}$, viscosity, density and crystal content - which are all relatively constant for a given chemical composition during the final stage of magma evolution. The stratovolcanoes show generally a slightly higher crystal content at a given composition, however this is not the rule. So 
Chapter 2 - Constraints on P-T conditions of crystallization and rates of magma formation before and after crustal thickening in the Central Andes

far all parameters have been more or less the same for each group and both flux - decompression melting and different P-T regimes as a function of crustal thickness have been ruled out in order to explain the formation of the vast Miocene volcanic fields.

Walker (1973) examined the emplacement of basaltic lava flows, where he primarily concentrated on the link between effusion rate and the flow length and verified that effusion rate, and not viscosity, is the primary aspect that influences not only flow length but also flow field type. Given a greater volume flux, the heat supplied to the flow is increased and thus creating a cooling-limited effect (Harris and Rowland, 2009). Since there is no obvious correlation between lava chemistry and morphology (Batiza et al., 1989), present morphological differences have been attributed to variations in eruption temperatures and effusion rates (Ballard et al., 1979, Luyendyk and Macdonald, 1985).

This seems to be the case in the Central Andes. From barometry data and especially the late crystallization of amphibole I conclude that the Miocene magmas erupt in a fast system, compared to the Pliocene/Quaternary system, which may be due to crustal thickening. Therefore degassing occurs mostly during ascend and at the surface and effusion rates are likely to be higher in a fast system as well. Consequently due to high effusion rates a thick crust forms on top of the lava flow creating a very efficient style of lava flow emplacement with low cooling rates and producing lava shields composed of long flows, which comprises most of the Central Andes during the Miocene (Anderson et al., 1995; Harris et al., 2000, 2002. Another consequence of a faster system during the Miocene is that the system was slightly higher in minimum temperatures (about $100{ }^{\circ} \mathrm{C}$, indicated by amphibole thermometry) leading to lower viscosities and allowing the lava to flow even more efficiently. If the amphiboles would have been identified as xenocrysts than no temperature differences are present, since ol, opc, cpx and plg crystallize all at the same temperatures and the argument for lower minimum temperatures leading to lower viscosities would not hold true.

Not only the volume calculations but also area extent supports this. Individual lava flows in Miocene fields have a mean volume of about 0.8 , while Pliocene stratovolcanoes are built from lava flows that have a mean volume of about $0.24 \mathrm{~km}^{3}$, approximately 3 times less voluminous (see Fig.12 and tables 5 and 6 ). The total volume of a certain volcano would not tell us much about the effusion rates since it might take much longer to build up a Pliocene/Quaternary stratovolcano than a Miocene shield volcano. It is therefore important to look at individual lava flows and therefore the increase in magma production rate and by implication the effusion rate can explain the formation of vast lava fields. An overview of the total eruptive products (lava flows, pyroclastic materials, eruption and erosion rates) is shown in chapter 3, where I will go into more detail explaining the important differences between effusion and eruption rate.

\subsubsection{Erosion patterns}

Another parameter, which must be taken into account, is erosion. Miocene volcanoes are commonly just remnants of a volcano and a possible statovolcano might be unrecognizable 
necessitating a discussion of erosional patterns to explain the shield morphology. Apart from the general arid climate, there is a precipitation gradient from north to south; the semi-humid in South Peru to the arid Altiplano to the hyperarid Puna (Pleczek et al., 2006). Miocene volcanoes display large volcanic fields some even with no obvious source area due to highly glaciated areas. Other volcanoes still show considerably eroded volcano remnants with prominent cones. Karátson et al. (2011) quantified the geomorphology of stratovolcanoes using Shuttle Radar Topography Mission data investigating erosion patterns. The initial state of morphology is an intact, highly circular volcano, resembling the Quaternary stratovolcanoes (Fig. 20a-b). Depending on the region, after approximately $1 \mathrm{Ma}$ the volcano starts developing valleys on the flanks (Fig. 20c), subsequently after significant incision, only deeply eroded cones with the remnants are still intact (sample: BAR-00-44). The final stage is a valley stage remnant volcano (sample: MIO-12-45), where erosion and coalescence of large valleys result in a completely degraded, lowered summit as shown in figures 3 and $20 \mathrm{~d}$ and is comparable to Karátson et al., (2011) findings.

The high degree of denudation for old stratovolcanoes, due to uplift, weathering, and erosion by fluvial and glacial processes results in a change in morphology leading to reduced elevation and subdued relief of the Miocene volcanoes. Together with high effusion rates during the Miocene, these two processes can form low angle volcanic shields.
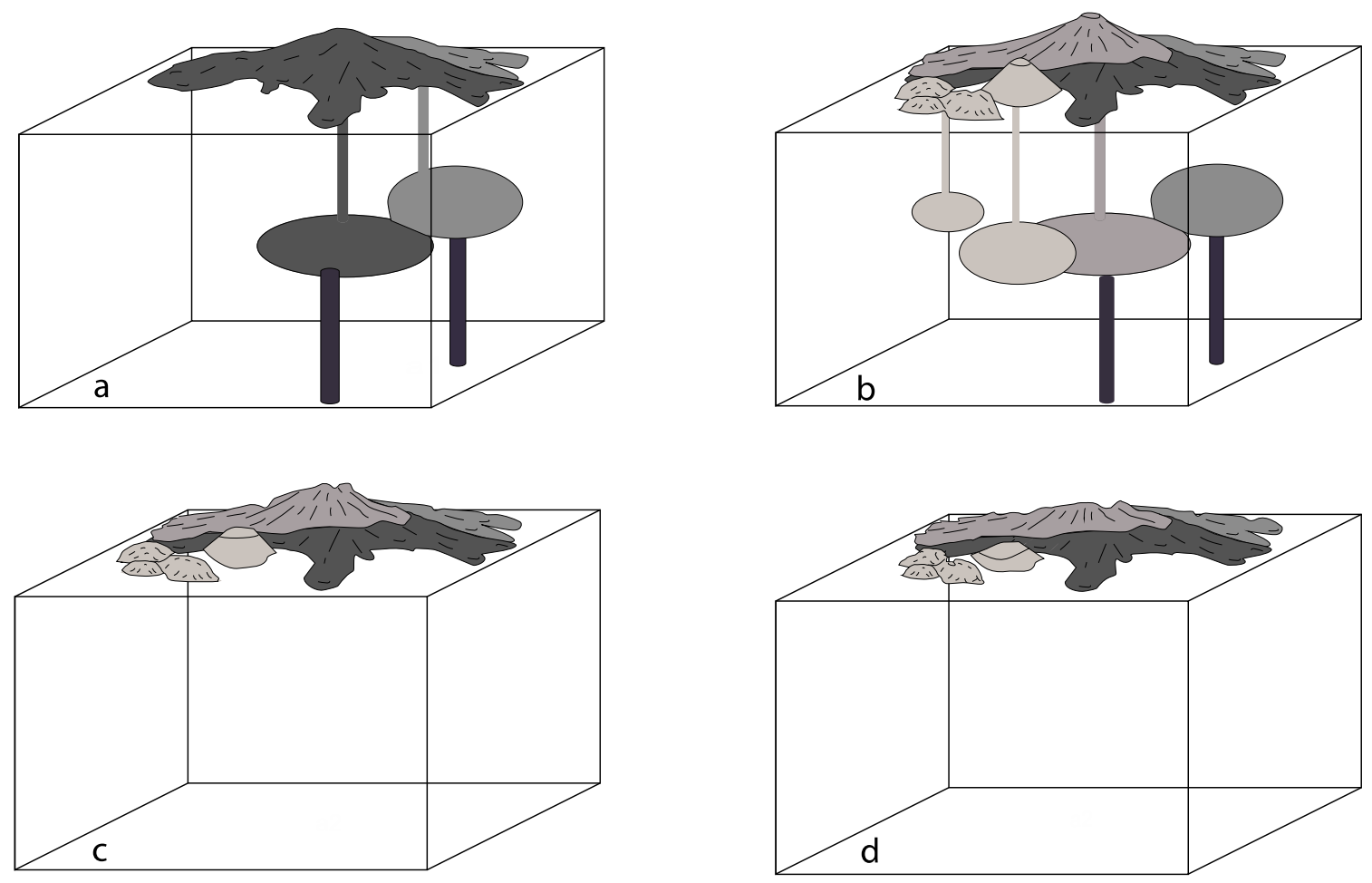
Fig. 20. Schematic step by step model of the evolution of Miocene stratovolcanoes. a-b) Formation of stratovolcanoes. They cover a relative large area (tables 6 and 7) and have not been subjected to erosion. c-d) A significant time span of uplift and erosion lead to a high degree of denudation creating over time shield like volcanoes.

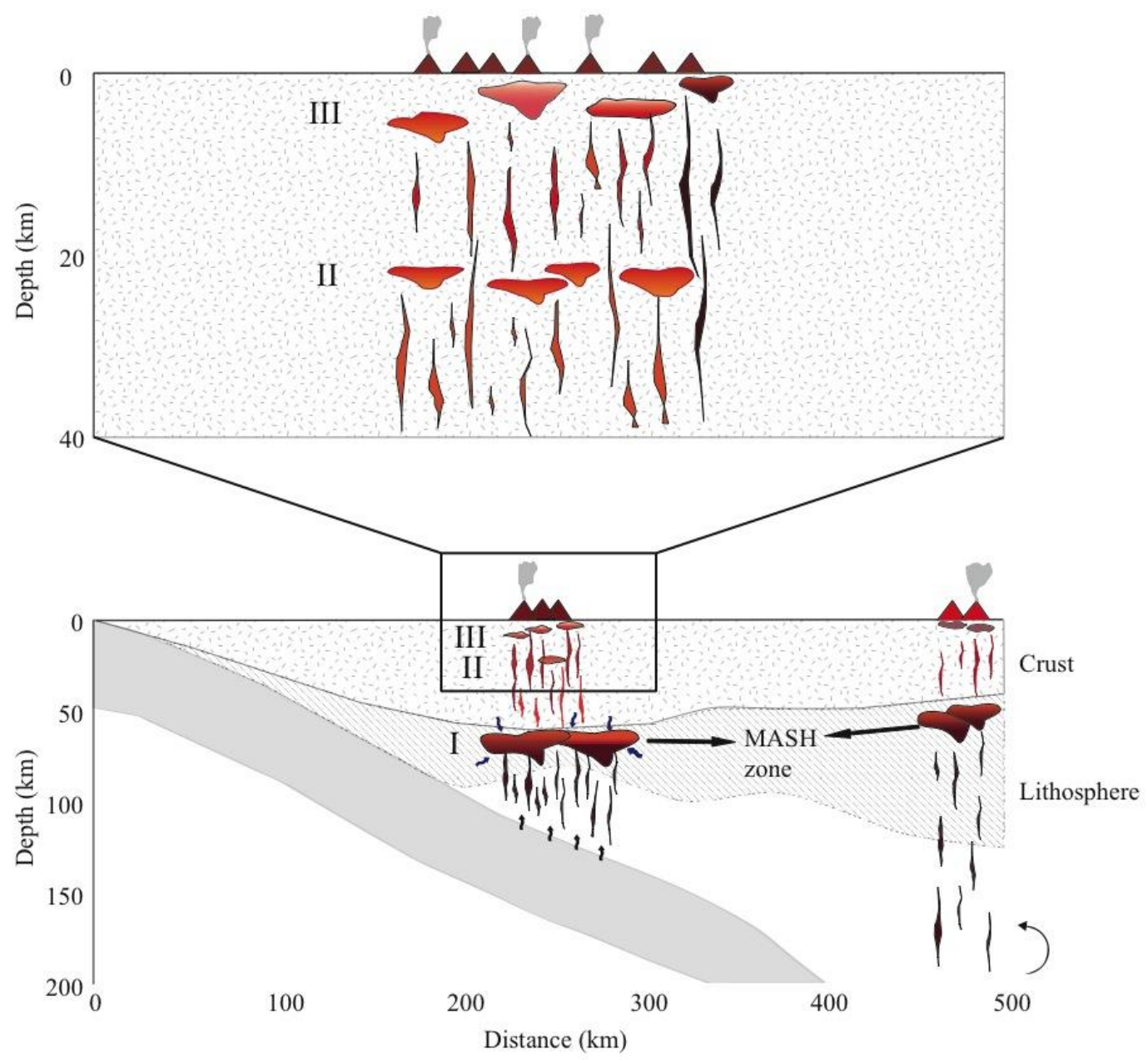

Fig. 21: Summary of the thermomechanical constrains. Melting begins at $\sim 115 \mathrm{~km}$ at the fore-arc. Influx from magma begins to pond beneath the crust-lithosphere boundary at a depth of $\sim 70 \mathrm{~km}$ (I) due to developing of a density and rheological barrier. Differentiation leads to more evolved magmas rising to the $\sim 22 \mathrm{~km}$ (II) and the 3 till $10 \mathrm{~km}$ boundary (III) within the upper crust from where they are erupted.

\subsection{Conclusions}

Although andesites are the most common composition within the Central Andes, they are only a final product of the magmatic evolution complex mafic recharge, differentiation, assimilation, fractionation and magma mixing between end members create thermal and chemical exchanges between magmas that affect physical properties of the new hybrid magma.

I show that the most significant parameters that influences volcano morphology i.e. viscosity, temperatures and water contents are constant through time and are independent of crustal thickness and thus have no influence nor have any control in determining the shape of the volcanoes in Southern 
Chapter 2 - Constraints on P-T conditions of crystallization and rates of magma formation before and after crustal thickening in the Central Andes

Peru and Northern Chile. Therefore P-T conditions of magma crystallization and storage must be decoupled from the deep mantle and mantle wedge, which can be argued by the increased depletion in HREE and Y within the Pliocene/Quaternary lavas relative to the Miocene lavashields. Also the lack of a negative Eu anomaly in all samples even with abundant and large plagioclase phenocrysts argues for decoupling and reflecting the shallower and later magmatic processes.

A slower magmatic system during the Pliocene and Quaternary, maybe due to crustal thickening ensured lower magmatic temperatures and by implication higher viscosities and low effusion rates created the small compound lava flows and leading to the clear distinction between the young stratovolcanoes and the Miocene shield-like volcanoes, which is a fast system.

The initial high effusion rates controlled the formation of vast stratovolcanoes with long single lava flows up to $20 \mathrm{~km}$. The final stage terminates into a shield volcano like morphology due to erosion, leaving the long single lava flows exposed. Therefore, the rate of effusion and by implication, magma production and upper crustal stress regime rather than eruption temperature are the primary factors that influenced flow length and flow field type. Subsequently, higher effusion rates leads to a smaller time fraction of differentiation and stalling at the all crystallization levels and has therefore less time for crystallization. The Miocene volcanic products consequently become more aphyric and contain less amphibole compared to the Pliocene-Quaternary eruptive products. 
Chapter 2 - Constraints on P-T conditions of crystallization and rates of magma formation before and after crustal thickening in the Central Andes

\section{References Cited}

Allmendinger RW, Jordan TE, Kay SM, Isacks BL (1997) The evolution of the Altiplano-Puna Plateau of the central Andes: Ann. Rev. Earth Plan. Sci. 25: 139-174

Anderson SW, Fink JH, Rose WI (1995) Mount St. Helens and Santiaguito lava domes: The effect of short-term eruption rate on surface texture and degassing processes: J. Volcanol. Geotherm. Res. 69:105-116

Asimow PD, Ghiorso MS (1998) Algorithmic Modifications Extending MELTS to Calculate Subsolidus Phase Relations. Am. Mineral. 83: 1127-1131

Bacon CR, Hirschmann MM (1988) $\mathrm{Mg} / \mathrm{Mn}$ partitioning as a test for equilibrium between coexisting Fe-Ti oxides. Am Mineral 73:57-61

Ballard RD, Holcomb RT, van Andel TH (1979) The Galapagos Rift at $86{ }^{\circ} \mathrm{W}$ : 3. Sheet flows, collapse pits and lava lakes of the rift valley: J. Geophys. Res. 84: 5407-5422

Banaszak M, Wörner, G (2012) Endmember magma compositions in the Central Andean Volcanic Zone obtained from Polytopic Vector Analysis, Abstract T21E-2620 presented at 2012 Fall Meeting, AGU, San Francisco, Calif., 3-7 Dec

Batiza R, Smith TL, Niu,Y (1989) Geological and petrologic evolution of seamounts near the EPR based on submersible and camera study: Mar. Geophys. Res. 11: 169-236

Bindeman IN, Davis Am, Drake M (1997) Ion microprobe study of plagioclase-basalt partition experiments at natural concentration level of trace elements. Geochim. Cosmoch. 6: 1175 - 1193

Bottinga Y, Weill DF (1970) Densities of liquid silicate systems calculated from partial molar volumes of oxide components. Am J Sci 269:169-182

Browne BK, Gardner JE (2006) The influence of magma ascent path on the texture, mineralogy and formation of hornblende reaction rims. Earth Planet Sci Lett. 246: 161-176

Cagnioncle AM, Parmentier EM, Elkins-Tanton LT (2007) Effect of solid flow above a subducting slab on water distribution and melting at convergent plate boundaries. J Geophys Res 112: B09402

Cameron BI, Walker JA, Carr MJ, Patino LC, Matias O, Feigenson MD (2002) Flux versus decompression melting at stratovolcanoes in southeastern Guatemala. J Volc Geotherm Res 119: $21-50$

Clavero JE, Sparks RSJ, Pringle MS Polanco, Gardeweg (2004). Evolution and volcanic hazards of Taapaca Volcanic Complex, Central Andes of Northern Chile. J. Geolog. Soc. 161: 603-618

Coira B, Kay SM, Viramonte J (1993) Upper Cenozoic magmatic evolution of the Argentine Puna - a model for changing subduction geometry. Int Geol Rev 35: 677-720 
Chapter 2 - Constraints on P-T conditions of crystallization and rates of magma formation before and after crustal thickening in the Central Andes

Devine JD, Rutherford MJ, Gardner JE (1998) Petrologic determination of ascent rates for the 19951997 Soufriere Hills Volcano andesitic magma. Geophyical Res Lett 25: 3673 - 3676

Elkins-Tanton LT, Grove TL, Donnelly-Nolan J (2001) Hot shallow melting under the Cascades volcanic arc. Geol. 29:631-634

Freer R, Hauptman Z (1978) An experimental study of magnetite- titanomagnetite interdiffusion: Phys. Earth Plan. Inter. 16: 223-231.

Eusterhues K (1993) Geochemie miozäner Vulkanite Nordchiles (18 ${ }^{\circ}$ to $\left.22^{\circ} \mathrm{S}\right)$ : (Master Thesis): Mainz, Germany, Mainz University, 75

Freymuth H (2006) Crystal size distribution in megacrystic dacites from Taapaca volcano, northern Chile Bachelor thesis

Ghiorso MS, Evans BW (2008) Thermodynamics of Rhombohedral Oxide Solid Solutions and a Revision of the Fe-Ti Two-oxide Geothermometer and Oxygen-barometer. Am J Sci 308:9571039

Ghiorso, Mark S., and Sack, Richard O. (1995) Chemical Mass Transfer in Magmatic Processes. IV. A Revised and Internally Consistent Thermodynamic Model for the Interpolation and Extrapolation of Liquid-Solid Equilibria in Magmatic Systems at Elevated Temperatures and Pressures. Contrib. Mineral. Petrol. 119:197-212

Gioncada A, Hauser N, Matteini M, Mazzuoli R, Omarini R (2006) Mingling and Mixing features in basaltic andesites of the Eastern Cordillera (Central Andes, $24^{\circ} \mathrm{S}$ ): a petrographic and microanalytical study. Per Mineral 75 (2-3):127-140

Giordano D, Russel JK, Dingwell DB (2008) Viscosity of magmatic liquids: A model Earth Planet. Sci. Lett. 271:123-134

Grocott J, Brown M, Dallmeyer G, Taylor G, Treloar P (1994) Mechanism of continental grow in extensionals arcs: an example from the Andean Plate Boundary Zone. Geol. 22:391-394

Grove TL, Parman SW, Bowring SA, Price R C, Baker MB (2002) The role of an H2O-rich fluid component in the generation of primitive basaltic andesites and andesites from Mt. Shasta region, N California. Contrib Mineral Petrol 142:375-396

Grove TL, Gerlach DC, Sando TW (1982) Origin of Calc-Alkaline lavas from Ruapehu Volcano and Related Vents, Taupo Volcanic Zone, New Zealand: J. Petrol. 28 531-567

Grunder AL, Klemetti EW, Feeley TC, McKee C M (2008) Eleven million years of arc volcanism at the Aucanquilcha Volcanic Cluster, northern Chilean Andes: implications for the lifespan and emplacement of plutons. Transactions of the Royal Society of Edinburgh: Earth Sci 97:415-436

Gualda GAR, Ghiorso MS, Lemons RV, Carley TL (2012) Rhyolite-MELTS: A modified calibration of MELTS optimized for silica-rich, fluid-bearing magmatic systems. J. Petrol. 53:875-890 
Chapter 2 - Constraints on P-T conditions of crystallization and rates of magma formation before and after crustal thickening in the Central Andes

Gutscher MA, Maury R, Eissen JP, Bourdon E (2000) Can Slab Melting Be Caused by Flat Subduction? Geol. 28:535-538

Harris AJL, Rowland SK (2009) Effusion rate controls on lava flow length and the role of heat loss: a review. Geol. Soc. London 2:33-51

Harris, A JL, Dehn J, Calvari S (2007) Lava effusion rate definition and measurement: a review. Bull. Volcanol. 70:1-22

Harris AJL, Flynn LP, Mati, ASO, Rose WI ((2002) The thermal stealth flows of Santiaguito: implications for the cooling and emplacement of dacitic block lava flows. Geol. Soc. Am. Bull. 114: $533-546$

Haschke, MR, Siebel W, Günther A, Scheuber E (2002) Balancing crustal thickening in arcs by tectonic vs. magmatic means. Geol 31:933-936

Hasegawa A, Nakajima J (2004) Geophysical constraints on slab subduction and arc magmatism. Geophys. Monogr. 150:81-93

Herron E, Heirtzler J (1967) Seafloor spreading near the Galapagos. Sci. 158:775-780.

Higgins MD (2000) Measurement of crystal size distributions. Am Mineral 85:1105-1116

Hildreth W, Moorbath S (1988) Crustal contributions to arc magmatism in the Andes of Central Chile. Contrib Mineral Petrol 98:455-480

Holland T, Blundy J (1994) Non-ideal interactions in calcic amphiboles and their bearing on amphibole-plagioclase thermometry. Contrib Mineral Petrol 116:433-447

Hoke L, Lamb S (2007) Cenozoic behind-arc volcanism in the Bolivian Andes, South America: Implications for mantle melt generation and lithospheric structure: J. Geol Soc London 164:795814

Hora J, Singer B, Wörner G, Beard BL, Jicha BR, Johnson CM (2009) Shallow reservoir and deep crustal control on differentiation of calc-alkaline and tholeiitic magmas Earth Planet Sci Lett 28:75-86

Hora JM, Singer BS, Wörner G (2007) Volcano evolution and eruptive flux on the thick crust of the Andean Central Volcanic Zone: ${ }^{40} \mathrm{Ar} /{ }^{39} \mathrm{Ar}$ constraints from Volcán Parinacota, Chile. Geol. Soc. Am. Bull. 119(3-4):343-362

Isacks B (1988) Uplift of the central andean plateau and bending of the Bolivian orocline. J Geophys Res, Solid Earth Plan. 93:3211-3231

Jaillard E, Ordonez M, Berrones G, Bengtson P, Bonhomme M, Jimenez N, Zambrano I (1996) Sedimentary and tectonic evolution of the arc zone of southwestern Ecuador during Late Cretaceous and early Tertiary times. J. S. Am. Earth Sci. 9:131-140 
Chapter 2 - Constraints on P-T conditions of crystallization and rates of magma formation before and after crustal thickening in the Central Andes

Jagoutz O; Müntener O, Schmidt MW, Burg J (2011) The roles of flux- and decompression melitng and thier respective fractionation lines for conitinental crust formation: Evidence from the Kohistan Arc. Earth Planet Sci Lett. 33: 25-36

Kaneoka I Guevara C (1984) K-Ar age determinations of late Tertiary and Quaternary Andean volcanic rocks, southern Peru: Geochem. J.18:233-239

Karátson D, Telbisz T, Wörner G (2012) Erosion rates and erosion patterns of Neogene to Quaternary stratovolcanoes in the Western Cordillera on the Central Andes:An SRTM DM based analysis. Geomorph. 139-140:122-135

Kay SM, Coira BL (2009) Shallowing and steepening subduction zones, continental lithospheric loss, magmatism, and crustal flow under the Central Andean Altiplano-Puna Plateau, in Kay, S.M., Ramos, V.A., and Dickinson, W.R., eds., Backbone of the Americas: Shallow Subduction, Plateau Uplift, and Ridge and Terrane Collision: Geol Soc Am Mem 204:229-259

Kay SM, Coira B, Viramonte J (1994) Young mafic back arc volcanic rocks as indicators of continental lithospheric delamination beneath the Argentine Puna Plateau, Central Andes: J. Geophys. Res. 99: 24,323-24,339, doi: 10.1029/94JB00896

Kay Sm, Godoy E, Kurtz A (2005) Episodic arc migration, crustal thickening, subduction erosion and magmatism in the south-central Andes: Geol Soc Am. 117: 67-88

Kay SM, Mpodozis C, Coira B (1999) Neogene magmatism, tectonism, and mineral deposits of the Central Andes (22 degrees to 33 degrees S latitude). Im Skinner B (ed) Geology and ore deposits in the Central Andes. Soc Econ Geol Spec Publ :27 - 59

Kay SM, Mpodozis C, Coira B (1996) Central Andean mantle-derived basalts and Neogene mantle enrichment beneath the Puna plateau. In: III International Symposium on Andean Geodynamics, Extended Abstract, Saint Malo, France, 583 - 586

Kay SM, Mpodozis C, Ramos VA, Munizaga F (1991) Magma source variations for mid-late Tertiary magmatic rocks associated with a swallowing subduction zone and a thickening crust in the Central Andes ( 28 to $33^{\circ} \mathrm{S}$ ): In Hamron, RS Rapela CW eds. Andean magmatism and its tectonic setting: Geol Soc Am., special paper. 265:113-137

Kimura JI, Gill JB, Kunikiyo T, Osaka I, Shimoshioiri Y, Katakuse M, Kakubuchi S, Nagao T, Furuyama K, Kamei A, Kawabata H, Nakajima J, van Keken PE, Stern RJ (2014) Diverse magmatic effects of subducting a hot slab in SW Japan: results from forward modeling, Geochem. Geophys. Geosyst

Klemetti EK, Grunder AL (2008) Volcanic evolution of Volcan Aucanquilcha, a long-lived, dacite volcano in the Central Andes of Northern Chile. Bull Volcanol 70:633-50

Lange RA, Frey HM, Hector J (2009) A thermodynamic model for the plagioclase-liquid hygrometer/thermometer. Am Mineral 94:494-506 
Chapter 2 - Constraints on P-T conditions of crystallization and rates of magma formation before and after crustal thickening in the Central Andes

Leake BE, Woolley AR, Arps CES, Birch WD, Gilbert MC, Grice JD, Hawthorne FC, Kato A, Kisch HJ, Krivovichev VG, Linthout K, Laird J, Mandarino JA, Maresch WV, Nickel EH, Rock NMS, Schumacher JC, Smith DC, Stephenson NCN, Ungaretti L, Whittaker EJW, Youzhi G (1997) Nomenclature of amphiboles: Report of the Subcommittee on Amphiboles of the International Mineralogical Association, Commission on New Minerals and Mineral Names. Am. Mineral. 82, $1019-1037$

Le Bas MJ, Le Maitre RW, Streckeisen A, Zanettin B (1986). A chemical classification of volcanic rocks on the total alkali_silica diagram. J Petr 27:745-750

Litvak VD, Poma S (2014) Petrogenesis of Miocene volcanic arc rocks over the Chilean-Pampean flat slab segment of the Central Andes constrained by mineral chemistry. Geollgica acta 12:151-170

Lindsay JM, Schmitt AK, Trumbull RB, de Silva SL, Siebel W, Emmermann R (2001b) Magmatic evolution of the La Pacana Caldera System, Central Andes, chili: compositional variation of two cogenetic large-volume felsic ignimbrites J of Petrol. 42:459-486

Loucks RR (1996) A precise olivine-augite Mg-Fe-exchange geothermometer. Contrib. Mineral. Petrol. 125:140-150

Luyendyk BP, Macdonald KC (1985) A geological transect across the crest of the EastPacificRise at $21^{\circ} \mathrm{N}$ latitude made from the deep submersible ALVIN: Mar. Geophys. Res. 7: 467-488

Mammerickx J, Klitgord K (1982) Northern East Pacific rise: evolution from 25 my to the present. J. Geophys. Res 87:6751-6759

Mamani M, Tassara A, Wörner G (2008) Composition and structural control of crustal domains in the central Andes. Geochem Geophys Geosyst 9: doi:10.1029/2007GC001925

Mamani M, Wörner G, Sempere T (2010) Geochemical variations in igneous rocks of the Central Andean Orocline. Geol Soc Am Bull 122:162-182

Manea VC, Pérez-Gussinyé M, Manea M (2012) Chilean flat slab subduction controlled by overriding plate thickness and trench rollback. Geol. 40:35-38

Matteini M, Mazzuoli R, Omarini R, Cas R, Maas R (2002) Geodynamical evolution of the central Andes at $24^{\circ} \mathrm{S}$ as inferred by magma composition along the Calama-Olocapato-El Toro transversal volcanic belt. J Volc Geotherm Res 118:225-228

McMillan NJ, Davidson Jl, Womer G, Harmon RS, Moorbath RS Lopez-Escobar L (1993) Influence of crustal thickening on arc magmatism: Nevados de Payachata volcanic region, northern Chile. Geol. 21:467-470

Mpodozis C, Arriagada C, Basso M, Roperch P, Cobbold P, Reich M. (2005) Late mesozoic to paleogene stratigraphy of the Salar de Atacama Basin, Antofagasta, Northern Chile : implications for the tectonic evolution of the Central Andes. Tectonophysics, 399 (1-4) Special Iss. 125-154 
Chapter 2 - Constraints on P-T conditions of crystallization and rates of magma formation before and after crustal thickening in the Central Andes

Mukasa SB. Tilton GR (1985) Zirkon U-Pb Ages of Super-Units in the Coastal Batholith, Peru. In The Nature and Origin of Granite; Pitcher, W.S., Ed.; Chapman and Hall: 61: 203-207.

Mukasa SB (1986) Zirkon U-Pb ages of super-units in the Coastal batholith, Peru: Implications for magmatic and tectonic processes. Geol. Soc. Am. Bull. 97, 241-254

Noble DC, Farrar E, Cobbing EJ (1979) The Nazca Group of south-central Peru: Age, source, and regional volcanic and tectonic significance. Earth and Planetary Science Letters 45:80-86.

Placzek CJ, Matmon A, Granger DE, Quade J, Niedermann S (2010) Evidence for active landscape evolution in the hyperarid Atacama from multiple terrestrial cosmogenic nuclides. Earth Plan Sci Lett 295:12-20

Plank T, Kelley KA, Murray RW, Ster LQ (2007) Chemical compostion of sediments subducting at the Izu-Bonin trench. Geochem Soc. 8 (4). Doi:10.1029/2006GC001444

Putirka KD (2008) Thermometers and barometers for volcanic systems. Rev Mineral Geochem 69:61120

Putirka K, Ryerson FJ, Mikaelian H (2003) New igneous thermobarometers for mafic and evolved lava compositions, based on clinopyroxene - liquid equilibria. Am Mineral 88:1542-1554

Putirka KD, Perfit M, Ryerson FJ, Jackson MG (2007) Ambient and excess mantle temperatures, olivine thermometry, and active vs. passive upwelling: Chem Geol 241:177-206

Putirka KD (2005) Mantle potential temperatures at Hawaii, Iceland, and the mid-ocean ridge system, as inferred from olivine phenocrysts: Evidence for thermally driven mantle plumes: Geochemistry Geophysics Geosystems, 6:14, doi:10.1029/2005GC000915.

Putirka K, Johnson M, Kinzler R, Longhi J, Walker D (1996) Thermobarometry of mafic igneous rocks based on clinopyroxene-liquid equilibria, 0-30 kb. Contrib. Mineral. Petrol. 123, 92-108

Reubi O, Blundy JD (2009) A dearth of intermediate melts at subduction zone volcanoes and the petrogenesis of arc andesites. Nature 461:1269-1273

Ridolfi F, Renzulli A (2012) Calcic amphiboles in calc-alkaline and alkaline magmas: thermobarometric and chemometric empirical equations valid up to $1,130{ }^{\circ} \mathrm{C}$ and $2.2 \mathrm{GPa}$. Contrib. Mineral. Petrol. 163 (5), 877 - 895

Ruprecht P, Wörner G (2007) Variable regimes in magma systems documented in plagioclase zoning patterns: El Misti stratovolcano and Andagua monogenetic cones (S. Peru). J. Volcano 1. Geotherm. Res. 165:142-162

Rutherford MJ, Hill PM (1993) Magma ascent rates from amphibolebreakdown; an experimental study applied to the 1980 - 1986 Mount St. Helens eruptions, J. Geophys. Res. 98 :19667-19685

Schmidt MW (1992) Amphibole composition in tonalite as a function of pressure: An experimental calibration of the AI-in-hornblende barometer. Contrib. Mineral. Petrol. 110: 304-310 
Chapter 2 - Constraints on P-T conditions of crystallization and rates of magma formation before and after crustal thickening in the Central Andes

Sdrolias M Mueller RD (2006) Controls on back-arc basin formation. Geochem Geophys Geosystems 7:Q04016, doi:10.1029/2005GC001090

Sisson TW, Grove TL, Coleman DS (1996) Hornblende gabbro sill complex at Onion Valley, California, and a mixing origin for the Sierra Nevada batholith. Contrib Mineral Petrol $126(1-2)$ : $81-108$

Solar P (1990) Relation of magmatic activity to plate dynamics in central Peru from Late Cretaceous to present, in Kay SM and Rapela CW, eds. Plutionism from Antarctica to Alaska. Geol Soc Am Special Paper 241:173-192

Solar P, Bonhomme MG (1988) New K-Ar age determination of intrusive rocks from the Cordillera Occidental and Altiplano of central Peru; identification of magmatic pulses and episodes of mineralization. J South Am Earth Sci. 1:169-177

Somoza R (1998) Updated Nazca (Farallon) - South America Relative Motions During the Last 40 My: implications for mountain building in the Central Andean region. J. S. Am. Earth Sci. 11: 211- 215

Sun S, McDonough WF (1989) Chemical and isotopic systematics of oceanic basalts: Implications for mantle composition and processes, in Saunders AD, Norry MJ, eds., Magmatism in the ocean basins: Geol Soc Spec Pub 42:313-345

Syracuse EM, van Keken EM, Abers GA (2010) The global range of subduction zone thermal models Phys Earth Planet Inter. 183: 73-90

Thouret JC, Finizola A, Fornari M, Legeley-Padovani A, Suni J, Frechen M (2001) Geology of El Misti volcano near the city of Arequipa, Peru. Geol Soc Am Bull. 113.12:1593- 1610

Thouret JC, Wörner G, Gunnell Y, Singer B, Zhang X, Souriot T (2007) Geochronologic and stratigraphic constraints on canyon incision and Miocene uplift of the Central Andes in Peru: Earth Plan. Sci. Lett. doi: 10.1016/j.epsl.2007.07.023

Trumbull RB, Riller U, Oncken O, Scheuber E, Munier K, Hongn F (2006) The timespace distribution of cenozoic volcanism in the south-central andes: a new data compilation and some tectonic implications. In O Oncken, G Chong, G Franz, P Giese, H.J Götze, VA. Ramos, MR. Strecker, and P Wigger (Eds.), The Andes: Active Subduction Orogeny, Frontier Earth Sci 29-43.

Ulmer P (2001) Partial melting in the mantle wedge - the role of $\mathrm{H}_{2} \mathrm{O}$ in the genesis of mantle-derived 'arc-related' magmas. Phys Earth Planet Int 127:215-232

van Hunen J, van den Berg AP, Vlaar NJ (2004) Various mechanisms to induce shallow flat subduction: A numerical parameter study, Phys Earth Planet Int 146:179-194

Walker GPL (1973) Lengths of lava flows. Phil Trans R Soc London 274:107-118 
Chapter 2 - Constraints on P-T conditions of crystallization and rates of magma formation before and after crustal thickening in the Central Andes

Walker JA, Carr MJ, Patino LC, Johnson CM, Feigenson MD, Ward, RL (1995) Abrupt change in magma generation processes across the Central America arc in southeastern Guatemala: fluxdominated melting near the base of the wedge to decompression melting near the top of the wedge. Contrib Mineral Petrol 120: 378-390

Wegner W (2002) Kristallgrößenverteilung in El Misti Andesiten: eine CSD Studie; Bachelorthesis

Wörner G, Harmon RS, Davidson J, Moorbath S, Turner TL, McMillan N Nye C, López-Escobar L, Moreno H (1988) The Nevados de Payachata Volcanic Region $18^{\circ} \mathrm{S} / 69^{\circ} \mathrm{W}, \mathrm{N}$. Chile. I. Geological, geochemical and isotopic observations. Bull. Volcanol. 30:287-303

Wörner G, Hammerschmidt K, Henjes-Kunst F, Lezaun J, Wilke H (2000) Geochronology (40Ar39Ar-, K-Ar-, and He-exposure-) ages of Cenozoic magmatic rocks from northern Chile (18 ${ }^{\circ}$ $\left.22^{\circ} \mathrm{S}\right)$. Implications for magmatism and tectonic evolution of the Central Andes: Revista Geologica Chile 27:205-240

Wörner G, Uhlig D, Kohler I, Seyfried H (2002) Evolution of the West Andean Escarpment at $18^{\circ} \mathrm{S}$ (N. Chile) during the last $25 \mathrm{Ma}$ : Uplift, erosion and collapse through time: Tectonophysics 345:183-198

Yáñez GA, Ranero CR, Huene R, Díaz J (2001) Magnetic anomaly interpretation across the southern central Andes (32-34 S): The role of the Juan Fernández Ridge in the late Tertiary evolution of the margin. Journal of Geophysical Research: Solid Earth (1978-2012) 106, 6325- 6345.

Yáñez G, Cembrano J, Pardo M, Ranero, C ,Selles D (2002) The Challenger-Juan Fernández-Maipo major tectonic transition of the Nazca-Andean subduction system at $33^{\circ}-34^{\circ} \mathrm{S}$ : Geodynamic evidence and implications, J. South Am. Earth Sci., 15(1):23-28, doi:10.1016/ S08959811(02)00004-4

Zellmer GF, Clavero JE (2006) Using trace element correlation patterns to decipher a sanidine crystal growth chronology: an example from Taapaca volcano, Central Andes. J Volcanol Geotherm Res 156(3-4):291-301. doi: 10.1016/j.jvolgeores.2006.03.004 


\title{
Chapter 3
}

\author{
Temporal changes in mantle wedge geometry and magma generation \\ processes in the Central Andes: Towards linking petrological data to \\ thermomechanical models
}

\section{Abstract}

Data from 220 volcanic centers in the Central Andes are compared in terms of volume and eruption rates. Calculation of eruption rates or volumes is challenging due to bases of the lava flows not being exposed, thickness variations of lava flows during their course, unknown paleo-topography, and erosion. For the northern $\left(\sim 4681 \mathrm{~km}^{3}\right)$ and central Altiplano $\left(\sim 5466 \mathrm{~km}^{3}\right)$, eruptive volumes are higher for Miocene volcanic centers compared to Pliocene/Quaternary stratovolcanoes (respectively $\sim 2110$ and $\sim 2973 \mathrm{~km}^{3}$ ), while for the southern Altiplano the eruption rates are higher for the younger stratovolcanoes (11470 compared to $12077 \mathrm{~km}^{3}$ ). When calculating the eruption rates, there is an overall increase in eruption rate through time at a single latitude and from north to south along the arc; for northern Altiplano 0.59 (Miocene) to $0.8 \mathrm{~km}^{3} / \mathrm{Ma} / \mathrm{km}$ (Quaternary); central Altiplano 1.46 (Miocene) to $1.75 \mathrm{~km}^{3} / \mathrm{Ma} / \mathrm{km}$ Quaternary) and for the southern Altiplano 1.45 (Miocene) to 3.06 $\mathrm{km}^{3} / \mathrm{Ma} / \mathrm{km}$ Quaternary) and is linked to pre-existing thicker crust in the south, since with crustal thickening the system is warmer and less energy is required for melting. These values do not consider ignimbrites and are in agreement with data from Francis and Hawkesworth (1994).

To evaluate chemical variations of lavas and calculate the mantle derived vs crustal component through time, thermodynamic models are vital tools; here I use a combination of MELTS for major elements and EC-RAxFC for trace elements and isotopes to advance the understanding of rates of magma formation and eruptions in the Central Andes. Unfortunately there is an overall poor agreement between the two models and analyzed samples this is probably due to the uniqueness of the Central Andes where subduction and mountain-building processes interact resulting in extreme conditions. Simple recharge, assimilation and mixing models may therefore be insufficient to fully explain chemical trends. However a new study by Bohrson et al., 2014 combines EC-RAxFC with MELTS. The so called Magma Chamber Simulator tracks enthalpies, composition of both major, trace elements and isotopes and temperatures of melt, fluid and solids, however this model is still in development and might in the future improve the modeling of trace element signatures in the Central 
Chapter 3 - Temporal changes in mantle wedge geometry and magma generation processes in the Central Andes: Towards linking petrological data to thermomechanical models

Andes.

To link petrological data to thermomechanical models, data from thermo- baro- and hygrometry, volumetric, eruption rates, intrusion : extrusion rates and even crustal contaminant are needed. To date, there is no existing thermomechanical model that combines petrology, fluid flow and upper crustal convection in a 3D framework that links these parameters to the evolution of the slab and mantle wedge geometry, tectonics and the timing of crustal thickening. From the thermomechanical models I believe it is obvious that an enhanced heat flow can significantly increase crustal temperatures, prompting the weakening of the crust and enhancing crustal thickening (Babeyko et al., 2002; Gerya, 2014). When taking this aspect into consideration the timing frame between crustal thickening, slab steepening, heat input and crustal melting is much faster than previously assumed.

\subsection{Introduction}

The Altiplano-Puna plateau of the Central Andes is the second largest plateau in the world (after Tibet) and has an average elevation of about $4 \mathrm{~km}$ and an area of more than $500000 \mathrm{~km}^{2}$. The plateau has resulted from about $300 \mathrm{~km}$ of late-Cenozoic crustal shortening at the western edge of the South American Plate. This shortening generated unusually thick, hot, and felsic continental crust (Isacks, 1988; Allmendinger and Gubbels, 1996; Allmendinger et al., 1997; Lamb et al., 1997; Kley and Monaldi 1998; Giese et al., 1999, Lucassen et al., 2001; Yuan et al., 2000, 2002; Beck and Zandt, 2002; Lamb and Davies, 2003; Oncken et al., 2006; Kay et al., 2009). The Central Andes result from subduction of the oceanic Nazca plate underneath the South American continent (Isacks, 1988; Allmendinger et al., 1997). Despite numerous publications (Isacks, 1988; Mégard et al., 1984; PardoCasas and Molnar, 1987, Somoza, 1988; Russo and Silver, 1994; Lamb and Davies, 2003, Allmendinger and Gubbels, 1996; Whitman et al., 1996, Koulakov et al., 2006, Babeyko et al., 2002; Springer and Förster, 1998; Yuan et al., 2000; Kay and Kay, 1993; Pope and Willet, 1998; Gephart, 1994; Oncken et al., 2006; Sobolev et al., 2006) about subduction dynamics and the origin of the Andean orogeny, many open questions remain. It is still unclear why and how that despite subduction and Western Cordillera tectonics beginning as early as the Cretaceous period, $140 \mathrm{Myr}$ ago (Mpodozis and Ramos, 1990), widening to the Eastern Cordillera and Bolivian orocline formation did not start until the Eocene, 45 Myr ago (Arriagada et al., 2008) and why the deformation then leaped $500 \mathrm{~km}$ to the Eastern Cordillera, and why and how it affected the plateau region much later. Also the timing of crustal thickening needs to be better constrained, since it varies from north to south and from west to east. Uplift began around $25 \mathrm{Ma}$ in the Altiplano segment and between 15 and $20 \mathrm{Ma}$ in the Puna as a result of flat subduction thinning and thermally softening the lithosphere underling the area that was to become the plateau (Isack, 1988; Allmendinger et al., 1997; Coira et al., 1993; Kay et al., 
Chapter 3 - Temporal changes in mantle wedge geometry and magma generation processes in the Central Andes: Towards linking petrological data to thermomechanical models

1995). Between 12 and 6 Ma shortening shifted towards the east and ceased in the Altiplano, while continuing in the Puna segment until $1-2$ Ma (Allmendinger et al., 1997).

Plate convergence and subduction have been ongoing since the Triassic, however compressional deformation related to significant uplift in the Central Andes only began in Eocene times with minimal deformation (Lamb et al., 1997). Deformation accelerated during $29-25 \mathrm{Ma}$, a time that correlates with an increase in plate convergence rate (Allmendinger et al., 1997), and subsequently causing a near doubling of crustal thickness. Timing is therefore the key in understanding the origin of the Central Andean orogeny. This difference in timing is created by different magmatic conditions, structures, deformation style and composition (Allmendiger and Gubbels, 1996; Kley and Monaldi, 1988, Oncken et al., 2006; Mamani et al., 2008, 2010). A complicating aspect is that several processes can produce a thickened crust: crustal shortening due to compression (Roeder, 1988; Sheffels, 1995; Allmendinger et al., 1997; Baby et al., 1997; Lamb et al., 1997; Gotberg et al., 2010), crustal underplating (Watts et al., 1995; Beck et al., 1996; Whitman, 1999; Sobolev et al., 2006), magmatic addition (Schmitz, 1994; Allmendinger et al., 1997; Lamb and Hoke, 1997; Gotberg et al., 2010; Gerya, 2014) ductile flow of the lower crust, thinning of the mantle lithosphere due to delamination (Sobolev et al., 2007; Garzione et al., 2006, 2007, 2008; Molnar and Garzione, 2007) and/ thermal anomalies - weakening (Allmendinger et al., 1997; Babeyko et al., 2002).

Also trace elements (HREE and $\mathrm{Y}$ depletions and high $\delta^{18} \mathrm{O}$ and ${ }^{87} \mathrm{Sr} /{ }^{86} \mathrm{Sr}$ isotopic ratios) reflect different degrees of crustal contamination in the Central Andes (Davidson and de Silva, 1992, 1995; Davidson et al., 1991; Kay et al., 1987; 1994, 1996; Wörner et al., 1988, 1992, 1994; Mamani et al., 2010) during Neogene crustal thickening. The main assimilation of crustal material takes place at high pressures near the MOHO (chapter 1) and is related with melting, assimilation, storage and homogenization processes at the crustal mantle boundary (MASH, Hildreth and Moorbath, 1988). Furthermore, during ascent from the mantle crust boundary magmas are further contaminated with crustal material. Freymuth et al. (in revision) suggests that the heavy oxygen isotopic ratios, relative to mantle values, in the Central Andes can be explained due to the assimilation of a few percent of crustal material.

To understand the complexity of the Central Andes it is important to consider the slab geometry, mantle wedge geometry, position of the Juan Fernandez ridge and the evolution of the Andean crust all together through time and understand how this influences the initial magmatic conditions, P-T conditions within the mantle and crust, crustal thickening, magmatic compositions, eruption rates and volumes all together. Consequently, a link between petrological data and thermomechanical models is needed. Unfortunately no such model exists yet and the large diversity of the suggested hypotheses reflects the complexity of the processes responsible for the Andean orogen, and furthermore shows the shortage of understanding of these processes. One way to improve such 
Chapter 3 - Temporal changes in mantle wedge geometry and magma generation processes in the Central Andes: Towards linking petrological data to thermomechanical models

understanding is to study the temporal correlation between tectonic shortening and those processes that possibly contribute to the deformation of the upper plate. Therefore I will discuss variations in slab dip, convergence rate, relative movement of the overriding plate, strength of mechanical coupling between the subducting and overriding plates, lithospheric structure, magmatic conditions, mass, heat fluxes and crustal thickening and try link them to petrological and volumetrical observations. Even though no new thermomechanical model is developed within this chapter, it can be still very important to evaluate the multiple existing models (Sobolev et al., 2006; Babeyko et al., 2002; Gerya, 2014; Wilson et al., 2014) with reference to the petrological and volumetric data presented below.

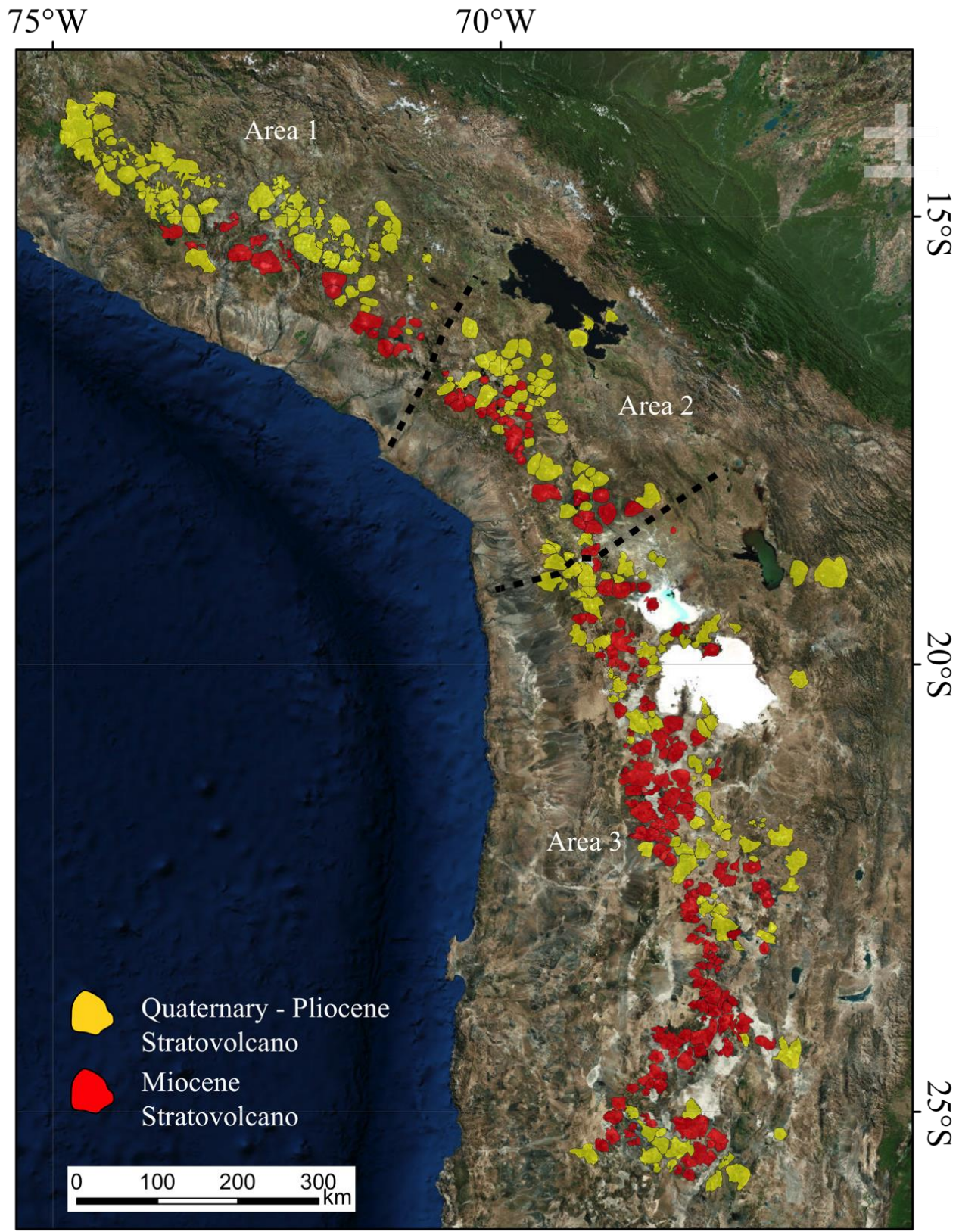

Fig. 1: Map of the Central Andes, indicating the geographic distribution of the Quaternary - Pliocene stratovolcanoes (yellow) and Miocene shields (red). Source: Esri, DigitalGlobe, GeoEye, i-cubed, USDA, USGS, AEX, Getmapping, Aerogrid, IGN, IGP, swisstopo, and the GIS User Community. 
Chapter 3 - Temporal changes in mantle wedge geometry and magma generation processes in the Central Andes: Towards linking petrological data to thermomechanical models

\subsection{Methods}

\subsubsection{Volume calculations}

For modeling it is important to investigate how eruptive volumes varied through time. In Chapter 2, I show a well-defined decrease in effusion rate from the Miocene to Pliocene - Quaternary. However direct observation and measurements of time elapsed is not available and besides an increase in effusion rate does not necessarily means an increase in eruption rate. Whereby (a) effusion rate is the volume flux of erupted lava that is feeding a flow at any particular point in time. The effusion rate is generally high during the onset of eruption and then exponentially decreases towards the end, and whereas (b) the eruption rate is the total volume of lava emplaced since the beginning of the eruption divided by the time since the eruption began. Eruption rate is thus the average lava output during a whole eruption or mostly used is, the lifetime of a volcano.

To estimate the volumes I looked at 419 volcanoes/volcanic centers of both Miocene (216) and Pliocene/Quaternary (203) age within three different areas (see Fig. 1) between $14{ }^{\circ} \mathrm{S}$ and $26^{\circ} \mathrm{S}$. The chosen areas are based on differing morphologies of the Miocene shieldvolcanoes, caused by a difference in climate (more arid towards the south). Simple volume calculations were carried out using Google Earth and geological maps.

For each shield volcano or stratovolcano, a polygon was carefully drawn for area calculations, and then average thickness was estimated. Outlining the polygons was challenging for older volcanoes as outlines based on morphological criteria (e.g. slope) is arbitrary due to erosion and common overprinting by younger units. For southern Peru geological maps (IGNEMET) specify additional information making the outlining process more precise. For Chile and Bolivia geological maps are not available for this study, but due to high aridity the outlines of the volcanoes are relatively easily determined. Furthermore, volcanoes in close proximity tend to merge as they evolve. Thus, in many cases, several volcanic edifices were combined in one feature as a volcanic complex.

Plotting several profiles through the volcanoes and averaging elevation values at the base of the slope determined the base-elevations. In particular, volcanoes located along the western escarpment tend to have lower base elevations on the western side than on the eastern flank. And thus despite that most lava flows are well exposed, it is difficult to make a good estimate of the volumes for multiple reasons, this holds especially for Miocene lava shields: First, the bases of the lava flows are often not exposed, thus it is problematic to estimate their total thickness. Second, the thickness of a lava flow varies during its course. Third, unknown paleo-topography, and fourth most show evidence of erosion, which makes it difficult to establish the original volume. The shape of the Pliocene/Quaternary stratovolcanoes is commonly conical. In these cases much easier volume calculations were carried out assuming a perfect cone.

Moreover, it is also possible to estimate the original thickness or volume of the Miocene lavas shields and the Pliocene/Quaternary stratovolcanoes, taking the amount of erosion and the degree of 
Chapter 3 - Temporal changes in mantle wedge geometry and magma generation processes in the Central Andes: Towards linking petrological data to thermomechanical models

denudation (erosion/original volume) into account (Karátson et al., 2011). Nevertheless, estimating the degree of denudation brings another problem. The degree of denudation is mostly dependent on age (or rather average age) and precise ages of many Miocene volcanoes are lacking. Besides, the uncertainty in denudation increases with age. Age data for all three segments are based on the Andean dataset (Mamani et al., 2010) and geological maps (IGNEMET). The erosion volumes and rates can be calculated using the initial volume of a volcanic complex (erosion/(denudation factor/100)) and the present volume plus the erosion, both values are equal. The equation is as follows: erosion/(denudation factor/100) $=$ present volume + erosion. Here the amount of erosion is varied until both values are equal.

Eruption rates have been calculated using the total volume of an area $\left(\mathrm{km}^{3}\right)$ divided by the time span $\left(\mathrm{km}^{3} / \mathrm{Ma}\right)$. Since volcanism started in Southern Peru and moved south through time, due to the southward migration of the intersection of the trench and the Juan Fernández ridge (Yáñez et al., 2001, 2002), the time span is different for all three areas. Based on radiogenic data from the Andean database (http://andes.gzg.geo.uni-goettingen.de) and the geological maps (IGNEMET) a time span for Miocene volcanoes have been chosen for area 1 to be 15 Ma (Fig.1), area 211 Ma and for area 3 $10 \mathrm{Ma}$. The used time span for Pliocene and Quaternary volcanoes is $5 \mathrm{Ma}$ for all three areas. The time of duration of activity has not been measured, due to a lack of radiogenic data (especially at Miocene volcanoes in remote areas) and without ages it is impossible to make and estimation of the duration of activity. Furthermore, since all three areas cover different arc length it is also important to calculate the eruption rates per arc length for comparison $\left(\mathrm{km}^{3} / \mathrm{Ma} / \mathrm{km}\right)$.

\subsubsection{Magma differentiation and assimilation: MELTS}

Determining the pressures and temperatures under which magma bodies reside in the crust and crystallize is a crucial parameter that influences phase assemblage, volatile exsolution and therefore also the eruption style. The pressures and temperatures calculated in chapter 2 are here tested using MELTS (Gualda et al., 2012) in an attempt to understand the history and evolution of magmatic systems in the Central Andes. Besides the amount the assimilant (in percentage) needs to be constrained on order to determine the amount of mantle magma vs. crustal magma. However, due to pressure limitations (up to $20 \mathrm{kbar}$ ) some careful consideration need to be taken, the MASH zone (Hilbreth and Moorbath, 1988) is calculated at $20 \mathrm{kbar}$ as well (chapter 2) and is therefore an absolute upper limit, since the error increases with higher pressures. Another problem with MELTS is that most of the andesites in the Andes are a mixture of different magmas and trends do not always follow magmatic differentiation but rather magma mixing trends (Banaszak, 2014) and MELTS is unable to model mixing of different end members. However, differentiation cannot be excluded and is a dominant process in fractionating magmas. MELTS might thus be able help to understand the history and evolution of magmatic systems in the Central Andes a bit better. More on magmatic differentiation is described in chapter 4. 
Chapter 3 - Temporal changes in mantle wedge geometry and magma generation processes in the Central Andes: Towards linking petrological data to thermomechanical models

I chose the parent composition; based on one of the most mafic samples present in the Central Andes (Bar-00-20) and calculated melt composition via mass balance. The parental composition in MELTS models is shown in Table 1. Even though this sample is likely already a product of minor differentiation, assimilation and mixing, based on the Andean database this sample is likely close in composition to the true parental melt. The daughter melt composition is taken after the first run of the parental melt based on end member analysis (Banaszak, 2014) and Figure 10 (Chapter 2) and is crystallized under various conditions (Table 6). Further assumptions are that both parent and daughter are melts (liquid without crystals, cumulates or enclaves).

The goal of model $1\left(\mathrm{M}_{\mathrm{frac}}\right)$ is to test how well the major and trace element changes between parental and daughter can be explained if they are due only to fractional crystallization of phenocryst phases, whereas model $2\left(\mathrm{M}_{\text {ass }}\right)$ includes assimilation as well. A satisfactory model should explain the chemical evolution of the magma and phenocrysts. Besides the chemical evolution, the volume of intrusions can be estimated with the combined results from the volume calculations (extrusion).

Table 1. Parental composition used for MELTS

\begin{tabular}{ccccccccccc}
$\mathrm{SiO}_{2}$ & $\mathrm{TiO}_{2}$ & $\mathrm{Al}_{2} \mathrm{O}_{3}$ & $\mathrm{Fe}_{2} \mathrm{O}_{3}$ & $\mathrm{FeO}$ & $\mathrm{MnO}$ & $\mathrm{MgO}$ & $\mathrm{CaO}$ & $\mathrm{Na}_{2} \mathrm{O}$ & $\mathrm{K}_{2} \mathrm{O}$ & $\mathrm{P}_{2} \mathrm{O}_{5}$ \\
\hline \hline 48.81 & 0.97 & 13.10 & 3.13 & 9.10 & 0.15 & 13.86 & 7.24 & 2.42 & 1.05 & 0.15
\end{tabular}

\subsubsection{Energy constrained model: EC- RAxFC}

Magmatism is an important mechanism for transport of energy and matter within the mantle and between mantle and crust. It is therefore also important to get good constraints on energy and mass balance in a magmatic system. The Energy constrained recharge, assimilation and fractional crystallization (EC-RAxFC) model follows the trace element and isotopic evolution of a batch of magma undergoing assimilation and fractional crystallization and has been created by Spera and Bohrson (2001, 2002 2004) and Bohrson and Spera (2001, 2003, 2007). EC-RAxFC models a magmatic composite system adiabatically sealed from its surroundings. The composite system includes the wall rock, a resident magma body and a recharge melt and are separated by diathermal and osmotic boundaries that allow heat exchange and partial chemical species exchange during an event of recharge, mixing and differentiation. The model tracks the system as magma cools and crystallizes whereas wall rock heats up and partially melts. A set of coupled non-linear differential equations describing the conservation equations are solved incrementally until magma and wall rock reach thermal equilibrium. Mechanisms of heat transport involve heat conduction into wall rock by hydrothermal convection and advection related with the recharge of fresh magma into an existing magma body. Fig. 2 illustrates the evolution path of the EC-RAxFC model.

Input is required in five different categories: thermal conditions (Table 2), melting functions, recharge, assimilant and initial conditions (Table 3). Besides the trace element and isotopic 
Chapter 3 - Temporal changes in mantle wedge geometry and magma generation processes in the Central Andes: Towards linking petrological data to thermomechanical models

composition of country rock, pristine magma and recharge magma need to be specified (table 4). Furthermore, variable additions of anatectic melt (amount of contamination) and recharge can be chosen. The output specifies the isotope and trace elements trajectory, the energy balance and material changes to the cooling crystallizing magma body. The model stops when the final magma body temperature is close to equilibrium temperature and is similar to the final country rock temperature. The model thus might give a good representation for estimation of the amount of mantle magma vs. crustal magma, which is an important constraint for any thermomechamical model.

For strontium, I used four different systems (Table 3) in order to get an overview of possible geochemical trends. In the first two systems I assume the initial concentrations of the magmatic reservoir are the same as for the recharge magma. System 1: The lower endmember with both initial strontium concentration of the magma and recharge of $500 \mathrm{ppm}$. System 2: The upper limit with strontium concentrations of $1800 \mathrm{ppm}$ in both the magma and recharge conditions. System 3 and 4 are a combination of system 1 and 2. System 3 has a recharge of $1800 \mathrm{ppm}$ and initial magmatic strontium concentration of $500 \mathrm{ppm}$. In this case basaltic magma intrudes lower crust of intermediate composition. In system 4 , the recharge magma has a strontium concentration of $500 \mathrm{ppm}$ and an initial strontium magma concentration of $1800 \mathrm{ppm}$, i.e. intermediate magma intrudes into the lower crust of mafic composition. All four system have been modeled using various Mro (recharge) and X (assimilant) ranges from $0-1$. For ${ }^{87} \mathrm{Sr} /{ }^{86} \mathrm{Sr}, \delta^{18} \mathrm{O}, \mathrm{Y}, \mathrm{Yb}$ and $\mathrm{Sm}$ input parameters see table 3 and 4.

In the upper crust, magma is intruded at a near-liquidus temperature of $1250{ }^{\circ} \mathrm{C}$ into a crust that has an initial temperature of $1000{ }^{\circ} \mathrm{C}(70 \mathrm{~km})$ (Giese, 1994) and a liquidus of $950{ }^{\circ} \mathrm{C}$. The local solidus temperature of the magma is $900{ }^{\circ} \mathrm{C}$. The parameters correspond to values typical of upper crust found by Taylor and McLennan, 1985 and thermometry data, chapter 2 . The more primitive recharge magma has a liquidus of $1250{ }^{\circ} \mathrm{C}$. Later on these parameter were varied in order to obtain the best fit (Table 4). 
(a)

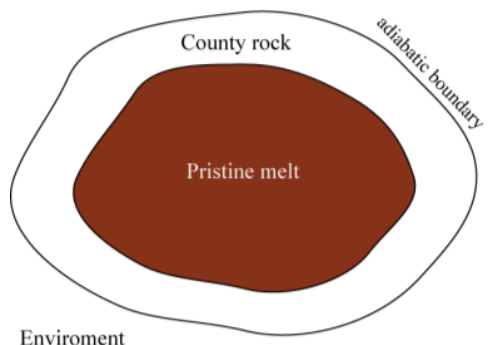

(b)

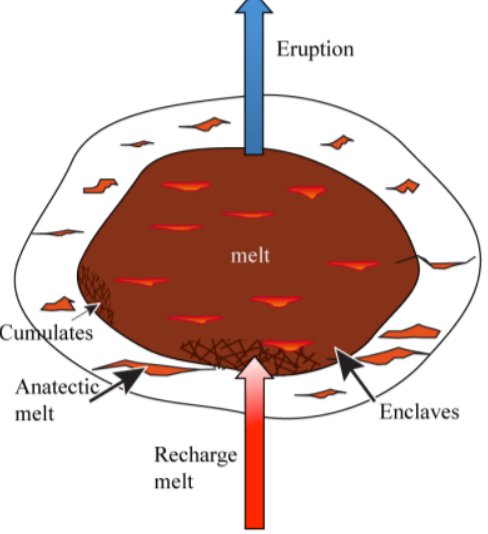

(c)

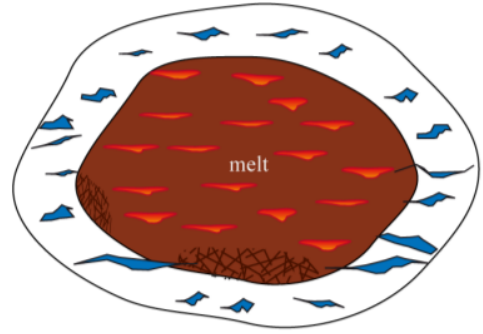

Fig.2. Schematic illustration of the EC-RAxFC model after Spera and Bohrson (2004). (a) the initial state is of the country rock, a pristine batch of chemically homogeneous isothermal melt, and a compositionally distinct recharge melt reservoir. (b) Recharge melt is added to the magma body at a prescribed rate. Formation of enclaves and mixing of recharge and pristine melts takes place. Heating of the country rock generates an $x$ amount of anatectic melt and contaminates the melt within the magma body. (c) Final thermal state where Tmelt $=$ Tanatetic-melt $=$ Tequilibrium.

Table 2. Selected thermal input parameters for integral calculations. Based on Giese (1994) and Bohrson and Spera (2001, 2003, 2007) and thermometry (Chapter 2).

\begin{tabular}{|c|c|c|c|}
\hline abbr. & & & unit \\
\hline$\overline{\mathrm{tlm}}$ & liquidus temperature of pristine magma & 1250 & ${ }^{\circ} \mathrm{C}$ \\
\hline tmo & initial temperature of pristine magma & 1250 & $\begin{array}{l}{ }^{\circ} \mathrm{C} \\
{ }^{\circ} \mathrm{C}\end{array}$ \\
\hline tla & liquidus temperature assimilant & 950 & ${ }^{\circ} \mathrm{C}$ \\
\hline tao & initial temperature assimilant & 1000 & $\begin{array}{l}{ }^{\circ} \mathrm{C} \\
{ }^{\circ} \mathrm{C}\end{array}$ \\
\hline tlr & liquidus temperature recharge magma & 1250 & ${ }^{\circ} \mathrm{C}$ \\
\hline tro & initial temperature recharge magma & 1250 & $\begin{array}{l}{ }^{\circ} \mathrm{C} \\
{ }^{\circ} \mathrm{C}\end{array}$ \\
\hline ts & solidus & 900 & ${ }^{\circ} \mathrm{C}$ \\
\hline cpm & specific heat of pristine magma & 1000 & $\mathrm{~J} / \mathrm{kg} \mathrm{K}$ \\
\hline сpa & specific heat of assimilant & 950 & $\mathrm{~J} / \mathrm{kg} \mathrm{K}$ \\
\hline cpr & specific heat of recharge magma & 1100 & $\mathrm{~J} / \mathrm{kg} \mathrm{K}$ \\
\hline $\mathrm{hm}$ & enthalpy of crystallization of pristine magma & 350000 & $\mathrm{~J} / \mathrm{kg}$ \\
\hline ha & enthalpy of melting of assimilant & 300000 & $\mathrm{~J} / \mathrm{kg}$ \\
\hline $\mathrm{hr}$ & enthalpy of crystallization of recharge magma & 400000 & $\mathrm{~J} / \mathrm{kg}$ \\
\hline
\end{tabular}


Chapter 3 - Temporal changes in mantle wedge geometry and magma generation processes in the Central Andes: Towards linking petrological data to thermomechanical models

Table 3. Used compositional parameters. Compositions based on the Central Andes database (http://andes.gzg.geo.unigoettingen.de) and on the geochemical earth refence model (GERM), (http:/earthref.org). Partition coefficients are within the experimental range (http:/earthref.org)

\begin{tabular}{|c|c|c|c|c|c|c|c|c|}
\hline & System 1 & System 2 & System 3 & System 4 & & & & \\
\hline $\begin{array}{l}\text { Element } \\
\text { in magma }\end{array}$ & 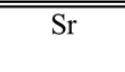 & $\overline{\mathrm{Sr}}$ & $\overline{\mathrm{Sr}}$ & 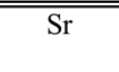 & 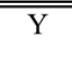 & 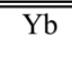 & 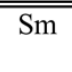 & 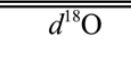 \\
\hline concentration (ppm) & 500 & 1800 & 500 & 1800 & 27 & 3 & 5 & 5.5 \\
\hline bulk Dmo & 0.9 & 0.8 & 0.9 & 0.8 & 0.7 & 0.6 & 0.5 & - \\
\hline $\begin{array}{l}\text { in assimilant } \\
\text { concentration (ppm) }\end{array}$ & 250 & 250 & 250 & 250 & 12 & 1 & 20 & 11 \\
\hline bulk Dmo & 1.1 & 1.1 & 1.1 & 1.1 & 2.4 & 1.4 & 3 & - \\
\hline $\begin{array}{l}\text { in recharge } \\
\text { concentration (ppm) }\end{array}$ & $\begin{array}{l}500 \\
0.8\end{array}$ & $\begin{array}{l}1800 \\
0.73\end{array}$ & $\begin{array}{l}1800 \\
0.73\end{array}$ & $\begin{array}{l}500 \\
0.8\end{array}$ & $\begin{array}{c}27 \\
0.65\end{array}$ & $\begin{array}{c}3 \\
0.55\end{array}$ & $\begin{array}{c}5 \\
0.45\end{array}$ & $\begin{array}{c}5.5 \\
-\end{array}$ \\
\hline $\begin{array}{l}\text { Isotope } \\
\text { ratio in magma } \\
\text { ratio in assimilant } \\
\text { ratio recharge }\end{array}$ & $\begin{array}{c}{ }^{87} \mathrm{Sr} /{ }^{86} \mathrm{Sr} \\
0.7045 \\
0.74 \\
0.703\end{array}$ & $\begin{array}{c}0.7045 \\
0.74 \\
0.703\end{array}$ & $\begin{array}{c}0.7045 \\
0.74 \\
0.703\end{array}$ & $\begin{array}{c}0.7045 \\
0.74 \\
0.703\end{array}$ & $\begin{array}{l}- \\
- \\
-\end{array}$ & $\begin{array}{l}- \\
-\end{array}$ & $\begin{array}{l}- \\
- \\
-\end{array}$ & $\begin{array}{c}\text { Ox. Conc } \\
0.47 \\
0.5 \\
0.47\end{array}$ \\
\hline
\end{tabular}

Table 4. Used compositional ranges of the parameters. See abbreviation table 2

\begin{tabular}{|c|c|c|c|c|c|c|c|}
\hline abbr. & & Element & $\mathrm{Sr}$ & $\mathrm{Y}$ & $\mathrm{Yb}$ & $\mathrm{Sm}$ & ${ }^{18} \mathrm{O} /{ }^{16} \mathrm{O}$ \\
\hline$\overline{\mathrm{tlm}}$ & $1200-1300$ & in magma & & & & & \\
\hline tmo & $1200-1300$ & concentration (ppm) & $500-1800$ & $18-35$ & $2-4$ & $5-8$ & 5.5 \\
\hline tla & $900-1000$ & in assimilant & & & & & \\
\hline tao & $500-700$ & concentration (ppm) & $250-1400$ & $12-20$ & $1-1.8$ & $4.5-20$ & $11-12$ \\
\hline tlr & $1200-1300$ & in recharge & & & & & \\
\hline tro & $1200-1300$ & concentration (ppm) & $500-1800$ & $18-35$ & $2-4$ & $5-8$ & 5.5 \\
\hline ts & $700-900$ & & & & & & \\
\hline
\end{tabular}

\subsection{Areal extent, volumes and eruption rates: comparison of Miocene lava shield and}

\section{Pliocene/Quaternary stratovolcanoes}

\subsubsection{Quality of data}

Extensive ignimbrite sheets dominate large portions of the topography of the Central Andes (especially for the western cordillera and Altiplano/Puna), whereas andesite volcanoes are small edifices and cover only small areas. I identified more than 400 edifices by using the combined dataset from the Andean database (Mamani et al., 2010), geological maps (IGNEMET) and Google earth. Estimates for the areal extent, volume, eruption rates and erosion rates (Table. 5) are given for three different segments (see Fig. 1).

However these data must be treated with care, due to large uncertainties in calculating the erosion rates, estimating the denudation factor and in estimating the time frame for the eruption rates, 
Chapter 3 - Temporal changes in mantle wedge geometry and magma generation processes in the Central Andes: Towards linking petrological data to thermomechanical models

as discussed in the method section. Aside from this, the duration of activity is different for each volcano, especially comparing compositionally distinct volcanoes. A period of $10^{3}$ years may be relatively long for a basaltic shield volcano, but only captures a part of an edifice-building cycle at a rhyolitic volcano. Therefore eruption rates for three larger areas (Fig. 1) are averaged over a longer period of time also due to a lack of radiometric ages.

Another parameter that should be considered is density. Since basalt is denser $(2.8-3.0$ $\left.\mathrm{g} / \mathrm{cm}^{3}\right)$ than rhyolite $\left(2.4-2.6 \mathrm{~g} / \mathrm{cm}^{3}\right)$ and it can be a fundamental parameter in volume calculations. Since volcanic edifices are often comprised of both basaltic, andesitic and dacitic or even rhyolitic lava flows, and the ratios are unknown, the density can therefore be discarded within the volume calculations.

Due to the large uncertainties involved, calculated volumes and eruption rates must be treated with care and are considered minimum values. Table 5 shows the volcanic output rates for Miocene and Pliocene/Quaternary volcanoes for the three areas (Fig.1). Besides a few Miocene shields and Pliocene/Quaternary stratovolcanoes were compared to earlier published data. For instance, Cerro Jatunpunco has a calculated volume of $64 \mathrm{~km}^{3}$ - literature $67 \mathrm{~km}^{3}$ (Karátson et al., 2011), El Misti calculated volume is $77 \mathrm{~km}^{3}$ - literature $80 \mathrm{~km}^{3}$ (Ruprecht and Wörner, 2007), Ubinas $58 \mathrm{~km}^{3}$ literature $56 \mathrm{~km}^{3}$ (Thouret et al., 2005). Area 2; Cerro Anallasji $114 \mathrm{~km}^{3}$ - literature $107 \mathrm{~km}^{3}$ (Karátson et al., 2011), Parinacota calculated $41 \mathrm{~km}^{3}$ - literature $41-51 \mathrm{~km}^{3}$ (Hora et al., 2007). Area 3; Incacamachi $51 \mathrm{~km}^{3}$ - literature $39 \mathrm{~km}^{3}$ (Karátson et al., 2011), Lascar calculated $58 \mathrm{~km}^{3}$ - literature $30-40 \mathrm{~km}^{3}$ (Gardeweg et al., 1998) showing a relative good agreement with each other.

Table 5. Volume calculation results and average eruption and erosion rates estimates

\begin{tabular}{|c|c|c|c|c|c|c|c|c|c|}
\hline Eruption rates & & $\begin{array}{l}\text { Area 1 } \\
\text { N. Altiplano } \\
\text { S. Peru }\end{array}$ & $\begin{array}{c}\text { Area } 2 \\
\text { C. Altiplano }\end{array}$ & $\begin{array}{c}\text { Area } 3 \\
\text { S. Altiplano }\end{array}$ & \multicolumn{2}{|l|}{ Erosion rates } & $\begin{array}{l}\text { Area } 1 \\
\text { N. Altiplano } \\
\text { S. Peru }\end{array}$ & $\begin{array}{c}\text { Area } 2 \\
\text { C. Altiplano }\end{array}$ & $\begin{array}{c}\text { Area } 3 \\
\text { S. Altiplano }\end{array}$ \\
\hline Total Volume & Miocene & $4 \quad 4681$ & 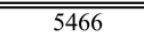 & 111470 & \multirow{2}{*}{$\begin{array}{l}\text { Av. Volume } \\
\mathrm{km}^{3}\end{array}$} & Miocene & 26.72 & 44 & 45 \\
\hline $\mathrm{km}^{3}$ & Pliocene & 2110 & 2973 & 12077 & & Pliocene & 3.62 & 7 & 11.2 \\
\hline Av. Volume & Miocene & 59 & 114 & 133 & \multirow{2}{*}{$\begin{array}{l}\text { Total Volume } \\
\mathrm{km}^{3}\end{array}$} & Miocene & 2111 & 2097 & 3984 \\
\hline $\mathrm{km}^{3}$ & Pliocene & 60 & 83 & 92 & & Pliocene & 128 & 253 & 1469 \\
\hline Time span & Miocene & 15 & 11 & 10 & Time span & Miocene & 15 & 11 & 10 \\
\hline $\mathrm{Ma}$ & Pliocene & 5 & 5 & 5 & $\mathrm{Ma}$ & Pliocene & 5 & 5 & 5 \\
\hline \multirow{2}{*}{$\begin{array}{l}\text { Eruption rates } \\
\mathrm{km}^{3} / \mathrm{Ma}\end{array}$} & Miocene & 312 & 497 & 1147 & \multirow{2}{*}{$\begin{array}{l}\text { Erosion rates } \\
\mathrm{km}^{3} / \mathrm{Ma}\end{array}$} & Miocene & 141 & 191 & 398 \\
\hline & Pliocene & 422 & 595 & 2415 & & Pliocene & 26 & 51 & 294 \\
\hline km Unit arc & & 530 & 340 & 790 & km Unit arc & & 530 & 340 & 790 \\
\hline \multirow[t]{4}{*}{$\mathrm{km}^{3} / \mathrm{Ma} / \mathrm{km}$} & Miocene & 0.59 & 1.46 & 1.45 & \multirow[t]{3}{*}{$\mathrm{km}^{3} / \mathrm{Ma} / \mathrm{km}$} & Miocene & 0.27 & 0.56 & 0.50 \\
\hline & \multirow[t]{3}{*}{ Pliocene } & 0.80 & 1.75 & 3.06 & & Pliocene & 0.05 & 0.15 & 0.37 \\
\hline & & 0.69 & 1.61 & 2.25 & & & & & \\
\hline & & & & & Av. Den & Miocene & 47 & 36 & 31 \\
\hline
\end{tabular}


Chapter 3 - Temporal changes in mantle wedge geometry and magma generation processes in the Central Andes: Towards linking petrological data to thermomechanical models

\subsubsection{Volumes and eruption rates for Miocene lava shields and Pliocene/Quaternary} stratovolcanoes trough time

The Central Andes volumes for both Miocene and Pliocene/Quaternary volcanic products comprise a minimum of $38770 \mathrm{~km}^{3}$ (Table 5). Miocene lava-shields have for area $1\left(4681 \mathrm{~km}^{3}\right)$ and 2 $\left(5466 \mathrm{~km}^{3}\right)$ in total a lager volume as Pliocene/Quaternary stratovolcanoes (respectively 2110 and $2973 \mathrm{~km}^{3}$ ). However for area 3 Miocene shields are less abundant and have therefore a lower volume $\left(11470 \mathrm{~km}^{3}\right)$ as Quaternary volcanoes $\left(12077 \mathrm{~km}^{3}\right)$. Looking at the average volume per volcano, it is surprising to see that there is no difference between Miocene and Pliocene/Quaternary average volume in area 1, however there is a clear difference for area 2 and 3 in average volume (larger for Miocene shields) and increases towards to south. However, these estimates do not include the tephra material ejected and lost during eruptions. Miocene erosion volumes for all three areas have been estimated to be approximately $2111 \mathrm{~km}^{3}$ for area $2097 \mathrm{~km}^{3}$ for Area 2 and $3984 \mathrm{~km}^{3}$ for area 3 (Table 5). For the Pliocene/Quaternary volcanoes the total erosion volume have been estimated to be approximately 128 $\mathrm{km}^{3}$ for area $253 \mathrm{~km}^{3}$ for Area 2 and $1469 \mathrm{~km}^{3}$ for area 3.

Besides the erupted volumes the eruption rate increases towards the south as well; for the Miocene volcanoes from $0.59 \mathrm{~km}^{3} / \mathrm{Ma} / \mathrm{km}$ (area 1) to $0.46 \mathrm{~km}^{3} / \mathrm{Ma} / \mathrm{km}$ (area 2) and to 1.45 $\mathrm{km}^{3} / \mathrm{Ma} / \mathrm{km}$ (area 3), for Pliocene and Quaternary volcanoes from $0.80 \mathrm{~km}^{3} / \mathrm{Ma} / \mathrm{km}$ (area 1) to 1.75 $\mathrm{km}^{3} / \mathrm{Ma} / \mathrm{km}$ (area 2) to $3.06 \mathrm{~km}^{3} / \mathrm{Ma} / \mathrm{km}$ (area 3). Moreover these values indicate a clear increase in eruption rate with time (see table 5). These values are in agreement with data from Francis and Hawkesworth (1994). They calculated eruption rates for volcanoes younger as $<1$ Ma to be 3.74 $\mathrm{km}^{3} / \mathrm{Ma} / \mathrm{km}$ and all volcanoes $<10 \mathrm{Ma}$ to be $1.59 \mathrm{~km}^{3} / \mathrm{Ma} / \mathrm{km}$ for the Central Volcanic Zone. I obtain almost the same value of $1.6 \mathrm{~km}^{3} / \mathrm{Ma} / \mathrm{km}$ for all volcanoes $<20 \mathrm{Ma}$.

Several explanations can be given for the difference in eruption rates. One of the main factors in controlling the style of eruption and magnitude is the rate of the westward drift of the South American plate (Kay and Coira, 2009; Oncken et al., 2006), but also the changing geometry of the Nazca plate is important. Moreover, as previously mentioned, the southward migration of the Juan Fernández ridge could be related to deformation patterns and periods of amagmatism prior to $24 \mathrm{Ma}$ in Southern Peru (Yáñez et al., 2001, 2002). Besides, plate motion predictions have shown that the Juan Fernández ridge only moved $2.5^{\circ}$ in latitude southward $(275 \mathrm{~km})$ in the last $12 \mathrm{Myr}$, while during Miocene times the migration was an order of magnitude faster $(200 \mathrm{~km} / \mathrm{Myr})$. During this period, fluids derived from the oceanic plate during flat subduction pre-condition the crust for later melting (James and Sack, 1999). The crust in the southern CVZ therefore had more time to be hydrated above a shallow subduction zone. With the steepening of the subducting slab, renewed asthenospheric mantle flow created the ideal conditions for high magma production rates. The corresponding increase in eruption rate of andesites is moreover consistent with ignimbrite eruptions (Kay and Coira, 2009; 
Chapter 3 - Temporal changes in mantle wedge geometry and magma generation processes in the Central Andes: Towards linking petrological data to thermomechanical models

Coira et al., 1993; Mamani et al., 2010; Brandmeier, 2014). A thicker and warmer crust, requiring less energy for melting during the Pliocene/Quaternary, might partly explain the difference with age.

\subsubsection{Fractionation and/or assimilation}

Since a satisfactory model should explain the chemical evolution of the magma and phenocrysts in order to see how well a certain model fits the chemical composition of minerals (olivine, opx and cpx) I characterized two different systems. For system $1\left(\mathrm{M}_{\text {frac }}\right)$ I tested how well the major and trace element changes between the parental melt (20 kbar) and daughter can be explained if they are due only to fractional crystallization of phenocryst phases. With $\mathrm{M}_{\mathrm{frac}} 1$ different models have been run with an initial 1, 2 or $3 \mathrm{H}_{2} \mathrm{O}$ wt \% and pressures of 1, 2, 4 or 6 kbar. Fractional crystallization allows the magma to differentiate to rhyolite composition of only at low pressures $(<1 \mathrm{kbar})$ At higher pressures, 6 kbar, silica content reaches only about $64 \mathrm{wt} \% \mathrm{SiO}_{2}$. Nevertheless a good match between the modeled and observed mineralogy is problematic to model since for most runs one of the three (olivine, cpx and opx) minerals did not crystallize, and where olivine is more abundant with low pressures clinopyroxene only tends to crystallize with pressure higher than $4 \mathrm{kbar}$. Conditions that produce the best match for andesitic magma and mineral composition are with an initial water content of $1 \mathrm{H}_{2} \mathrm{O}$ wt $\%$ (Table 6). Mineral compositions (chapter 2, appendix) for olivine has the lowest deviation when comparing EMPA data with the modeled mineral composition by MELTS when using a pressure of $1 \mathrm{kbar}$ while opx and cpx have the best match at $6 \mathrm{kbar}$ (see table 6). Besides the high crystallization temperatures of opx at 4 and 6 kbar are unrealistically high (up to $1230{ }^{\circ} \mathrm{C}$ ). The low olivine and high opx, cpx crystallization pressures predicted by MELTS suggest that the model lacks an additional chemical input.

For system $2\left(\mathrm{M}_{\text {ass }}\right)$ I added an assimilant as an additional source of melt. During the crystallization of the parental melt at $20 \mathrm{kbar}$, dacite is added as the assimilant at different proportions (Table 7). At the second stage, daughter dacitic composition is being added (up to $5 \%$ ) between 1 and $6 \mathrm{kbar}$ as an assimilant. The dominance for lower crustal processes instead of upper crustal processes is based on Hildreth and Moorbath 1988; Davidson et al. 1991. Nevertheless even with an additional source, a good match is difficult to obtain (Table 7), here the measured EMPA mineral composition the modeled MELTS mineral compositions are shown and indicating the deviation between analytical and the modeled obtained compositions. Unlike $S_{\text {frac }}$ some runs were able to crystallize olivine, clinopyroxene and orthopyroxene, but only at 4 kbar and $\mathrm{H}_{2} \mathrm{O}$ of $2 \mathrm{wt} \%$. However, a satisfactory model should explain the chemical evolution of the magma and phenocrysts in order to see how well a certain model fits the chemical composition of minerals (olivine, opx, cpx and feldspar). The main problem for olivine modeling is the overestimation of $\mathrm{MgO}$ and underestimation of $\mathrm{FeO}$, while for clinopyroxene $\mathrm{CaO}$ is underestimated and $\mathrm{Fe}_{\text {tot }}$ and $\mathrm{MgO}$ overestimated. $\mathrm{MgO}$ seems a general problem since it is also overestimated for orthopyoxene. There exists a similar problem is for $\mathrm{CaO}$, 
Chapter 3 - Temporal changes in mantle wedge geometry and magma generation processes in the Central Andes: Towards linking petrological data to thermomechanical models

which is being underestimated in clinopyroxene and in feldspar (Table 7). When adjusting the assimilant parameters (mass, temperature and increments of added assimilant) only minor variations occur within the chemical composition of the minerals (Table 7).

Since almost none of the modeled chemical mineral compositions are comparable to the measured EMPA mineral compositions, the model does not seen to work either for just fractionation or with the addition of an assimilant. This is actually not surprising since I also showed and discussed in chapter 2 that mixing of is an dominant processes as well and since most andesites in the Andes are a mixture of different end members. However it is still important to analyze the MELTS results. The best model or fit is run nr. 5 (lowest total deviation), and crystallizes all present phases in andesites. The model proposes a magmatic reservoir or MASH zone at $20 \mathrm{kbar}$ with an water content of $2 \mathrm{wt} \%$ and $20 \%$ addition of an assimilant. The used crustal temperature of $900{ }^{\circ} \mathrm{C}$ at $20 \mathrm{kbar}$ is actually to low according to the P-T models of Giese (1994) in the Central Andes. However, models using crustal temperatures of $1100{ }^{\circ} \mathrm{C}$ give higher deviations (Table 7). $20 \%$ of crustal materials also seems slightly on the lower side, Freymuth et al. (in revision) calculated the fraction of crustal material of $28 \%$ and is based on $\mathrm{O}$ isotopes. From the MASH zone the magma than ascends to 4 kbar where most of the crystallization takes place. This crystallization pressure is higher than previous modeled pressures by MELTS (chapter 2; average 2 kbar) confirming that pressure calculations by MELTS are not reliable for the Central Andes.

Table 6. Runs by MELTS for $\mathbf{M}_{\text {frac }}$. Composition is compared to measured EMPA minerals of similar bulk composition as model-measured.

\begin{tabular}{ccccccccccccc} 
& $\mathrm{P}$ & $\mathrm{D}$ & $\mathrm{O}$ Olivine & \multicolumn{4}{c}{ Clinopyroxene } & \multicolumn{3}{c}{ Orthopyroxene } \\
$\mathrm{nr}$ & $\mathrm{H} 2 \mathrm{O}$ & Pressure (kbar) & $\mathrm{SiO}_{2}$ & $\mathrm{FeO}$ & $\mathrm{MgO}$ & $\mathrm{SiO}_{2}$ & $\mathrm{Fe}_{\text {tot }}$ & $\mathrm{Al}_{2} \mathrm{O}_{3}$ & $\mathrm{CaO}$ & $\mathrm{SiO}_{2}$ & $\mathrm{Fetot}$ & $\mathrm{MgO}$ \\
\hline \hline 1 & 1 & 1 & 0 & 6.2 & -0.2 & - & - & - & - & -1.3 & 24 & -6.2 \\
2 & 1 & 2 & 1.2 & 7 & -5 & - & - & - & - & -0.7 & 6 & -5.3 \\
3 & 1 & 4 & - & - & - & - & - & - & - & -0.6 & 4 & -3.7 \\
4 & 1 & 6 & - & - & - & 3.4 & -0.1 & -4.2 & 0.2 & -0.1 & 3 & -3.1 \\
5 & 2 & 1 & -0.2 & 6.4 & -5.2 & - & - & - & - & -1.4 & 7.2 & -6.4 \\
6 & 2 & 2 & -1.3 & 7.6 & -5.9 & 7.6 & 2.2 & -5 & -1.6 & -1.1 & 6.7 & -5.8 \\
7 & 2 & 4 & - & - & - & 6.4 & 1.4 & -4.4 & -1.1 & -1.1 & 4.8 & -4.6 \\
8 & 2 & 6 & - & - & - & 6.9 & 0.58 & -4.9 & -0.6 & 0.6 & 4 & -3.9 \\
9 & 3 & 1 & -0.3 & 6 & -4.4 & - & - & - & - & -1.4 & 6.9 & -6.3 \\
10 & 3 & 2 & -1.3 & 7.5 & -5.8 & 19.6 & 3 & -14 & -2.7 & -1.1 & 6.68 & -5.9 \\
11 & 3 & 4 & - & - & - & 19.2 & 1.7 & 12.5 & -2.1 & -1.5 & 5.3 & -5 \\
12 & 3 & 6 & - & - & - & 10.6 & 0.8 & 8.6 & -2.3 & -1.6 & 4.5 & -4.3
\end{tabular}


Chapter 3 - Temporal changes in mantle wedge geometry and magma generation processes in the Central Andes: Towards linking petrological data to thermomechanical models

Table 7. Runs by MELTS for $\mathbf{M}_{\text {ass. }}$ Composition is compared to measured daughter EMPA minerals of similar bulk composition as model-measured.

\begin{tabular}{|c|c|c|c|c|c|c|c|c|c|c|c|c|c|c|c|c|c|c|c|c|c|c|c|}
\hline \multirow[b]{2}{*}{$\mathrm{nr}$} & \multicolumn{2}{|l|}{ Parent } & \multirow{2}{*}{$\begin{array}{c}\text { Daughter } \\
\text { Pressure (kbar) }\end{array}$} & \multicolumn{2}{|c|}{ similant parental melt } & \multirow[b]{2}{*}{ Increments } & \multicolumn{3}{|c|}{ assimilant daughter melt } & \multirow{2}{*}{$\begin{array}{l}\text { Olivine } \\
\mathrm{SiO}_{2}\end{array}$} & \multirow[b]{2}{*}{$\mathrm{Fe}_{\mathrm{set}}$} & \multicolumn{3}{|c|}{ Clinopyroxene } & \multirow[b]{2}{*}{$\mathrm{MgO}$} & \multicolumn{3}{|c|}{ Orthopyroxene } & \multicolumn{3}{|c|}{ Feldspar } & \multirow[b]{2}{*}{$\mathrm{CaO}$} & \multirow[b]{2}{*}{$\mathrm{Na} 2 \mathrm{O}$} \\
\hline & $\mathrm{H}_{2} \mathrm{O}(\mathrm{w}+\%)$ & Pressure (kbar) & & Mass & $\mathrm{T}\left({ }^{\circ} \mathrm{C}\right)$ & & Mass & $\mathrm{T}\left({ }^{\circ} \mathrm{C}\right)$ & Increments & & & $\mathrm{MgO}$ & $\mathrm{SiO}_{2}$ & $\mathrm{Fe}_{\text {tot }}$ & & $\mathrm{CaO}$ & $\mathrm{SiO}_{2}$ & $\mathrm{Fe}_{\mathrm{stat}}$ & $\mathrm{MgO}$ & $\mathrm{SiO}_{2}$ & $\mathrm{Al}_{2} \mathrm{O}_{3}$ & & \\
\hline 1 & 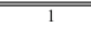 & 20 & 1 & 20 & 900 & 20 & $\overline{5}$ & 500 & 2 & 1.4 & -12.3 & 6.74 & 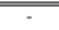 & 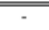 & - & 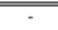 & 2.4 & $\begin{array}{c}-8.6 \\
\end{array}$ & 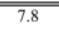 & 9.1 & -6.2 & -7.4 & 2.1 \\
\hline 2 & 1 & 20 & 2 & 20 & 900 & 20 & 5 & 500 & 2 & 4.7 & -26.6 & 19.8 & - & - & - & 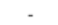 & 0.7 & -7.3 & 6.19 & 9.1 & -6.2 & -7.4 & 2.1 \\
\hline 3 & 1 & 20 & 4 & 20 & 900 & 20 & 5 & 500 & 2 & 4.7 & -25.2 & 19.7 & -2.2 & 2.6 & 13.66 & -18.3 & - & - & - & 8 & -5.3 & -6.4 & 2.2 \\
\hline 4 & 1 & 20 & 6 & 20 & 900 & 20 & 5 & 500 & 2 & - & - & - & - & - & - & - & 1.7 & -5.8 & 4 & 8.8 & -6.1 & -7.2 & 1.8 \\
\hline 5 & 2 & 20 & 1 & 20 & 900 & 20 & 5 & 500 & 2 & 2.1 & -13.1 & 9.8 & - & . & . & . & 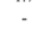 & 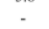 & . & 7.9 & -5.1 & -6.1 & 1.8 \\
\hline 6 & 2 & 20 & 2 & 20 & 900 & 20 & 5 & 500 & 2 & 2.2 & -13.4 & 10.3 & - & - & - & . & - & - & . & 9.7 & -6.6 & -7.8 & 2.6 \\
\hline 7 & 2 & 20 & 4 & 20 & 900 & 20 & 5 & 500 & 2 & 2.2 & -13 & 10.1 & -2.9 & 1.5 & 9.6 & -14.4 & 0.7 & -6.3 & 5.3 & 8 & -5.3 & -6.3 & 1.9 \\
\hline 8 & 2 & 20 & 6 & 20 & 900 & 20 & 5 & 500 & 2 & . & . & . & -1.5 & 0.9 & 10.7 & -14.8 & 0.3 & -5.3 & 4.4 & 9.8 & -6.7 & -7.9 & 2.3 \\
\hline 9 & 3 & 20 & 1 & 20 & 900 & 20 & 5 & 500 & 2 & 2.8 & -27.3 & 13 & - & . & . & . & . & - & . & 8.4 & -5.5 & -6.5 & 2.2 \\
\hline 10 & 3 & 20 & 2 & 20 & 900 & 20 & 5 & 500 & 2 & $\because$ & . & - & . & . & . & . & . & . & . & 10.3 & -7 & -8.3 & 3 \\
\hline 11 & 3 & 20 & 4 & 20 & 900 & 20 & 5 & 500 & 2 & - & - & - & - & - & - & - & - & - & - & 9.5 & -9.6 & -7.5 & 1.7 \\
\hline 12 & 3 & 20 & 6 & 20 & 900 & 20 & 5 & 500 & 2 & - & - & - & - & - & - & - & - & - & - & 9.7 & -6.5 & -7.7 & 2.6 \\
\hline 13 & 2 & 20 & 4 & 10 & 900 & 20 & 5 & 500 & 2 & 2.8 & -12.9 & 9.3 & -4 & 1.2 & 8.7 & -13.47 & 0.7 & -6.3 & 5.4 & 9.9 & -6.7 & -8 & 2.6 \\
\hline 14 & 2 & 20 & 4 & 30 & 900 & 20 & 5 & 500 & 2 & 2.8 & -12 & 9 & -4.8 & 1.2 & 8.3 & -13.1 & 0.7 & -6.2 & 5.2 & 9.3 & -6.3 & -7.5 & 2.4 \\
\hline 15 & 2 & 20 & 4 & 20 & 1100 & 20 & 5 & 500 & 2 & 2.9 & -13 & 9.5 & -2.8 & 1.5 & 9.8 & -14.5 & . & - & - & 10 & -6.8 & -6.3 & 2.7 \\
\hline 16 & 2 & 20 & 4 & 20 & 1100 & 10 & 5 & 500 & 2 & 2.8 & -12.9 & 9.3 & -12.2 & 0.3 & 0.9 & -5.8 & 0.4 & -6.2 & 4.9 & 10 & -6.8 & -8.1 & 2.5 \\
\hline 17 & 2 & 20 & 4 & 20 & 1100 & 30 & 5 & 500 & 2 & 2.8 & -12.9 & 9.3 & -3.3 & 1.4 & 9.3 & -14.1 & 0.7 & -6.3 & 5.3 & 9.9 & -6.8 & -8 & 2.6 \\
\hline 18 & 2 & 20 & 4 & 25 & 1100 & 10 & 5 & 500 & 2 & 2.2 & -12.9 & 10.1 & -4.1 & 1.3 & 8.4 & -13.2 & 0.6 & -6.4 & 5.4 & 9.8 & -6.7 & -7.9 & 2.5 \\
\hline 19 & 2 & 20 & 4 & 25 & 1100 & 10 & 5 & 600 & 2 & 2.1 & -13 & 10.1 & -4.2 & 1.3 & 8.3 & -13.1 & 0.7 & -6.2 & 5.2 & 9.8 & -6.7 & -7.9 & 2.5 \\
\hline 20 & 2 & 20 & 4 & 25 & 1100 & 10 & 5 & 400 & 2 & 2.1 & -13.1 & 10.1 & -4.2 & 1.3 & 8.3 & -13.1 & 0.7 & -6.2 & 5.2 & 9.8 & -6.7 & -7.9 & 2.5 \\
\hline
\end{tabular}

\subsection{EC-RAxFC}

\subsubsection{Geochemical trends}

The relative mass fractions of crystals, assimilant and recharge magma as well as the composition of the assimilant and recharge component are important in defining how open a system is and how it evolves. Here, I present the results of EC-RAxFC to demonstrate the effect of assimilation and recharge on chemical signatures (trace element and isotopic). Since input is required in five different categories, it is first important to understand the effect of each parameter. This is especially true for the variables recharge (Mro) and the fraction of anatectic melt $(\mathrm{X})$, which both can vary between $0-1$. The chosen value of recharge during the simulation is the total mass of recharge magma involved in the simulation and is the same value of the total mass of the magma body at the start of the simulation. For example, with a recharge mass (Mro) chosen value of 0.5, the mass of recharge that enters the magma chamber is half of the mass of the magma chamber at the start of the simulation. For the anatectic melts, energy conservation controls the amount of melt that forms in the country rock, however the user-input variable $\mathrm{X}$ defines the fraction of this partial melt that enters the magma body, relative to the amount generated. The remaining non-mixed fraction remains within the country rock sub system.

In figures 3 and 4 the effect of the relative fraction of anatectic melt (X) and relative fraction of recharge (Mro) on ${ }^{87} \mathrm{Sr} /{ }^{86} \mathrm{Sr}$ vs. strontium and are shown in a diagram for all four systems. System 1: The lower endmember with both initial strontium concentration of the magma and recharge of 500 ppm. System 2: The upper limit with strontium concentrations of $1800 \mathrm{ppm}$ in both the magma and recharge conditions. System 3 has a recharge of $1800 \mathrm{ppm}$ and initial magmatic strontium concentration of $500 \mathrm{ppm}$ and on system 4, the recharge magma has a strontium concentration of 500 ppm and an initial strontium magma concentration of $1800 \mathrm{ppm}$. The effect on increasing mass of 
Chapter 3 - Temporal changes in mantle wedge geometry and magma generation processes in the Central Andes: Towards linking petrological data to thermomechanical models

assimilation and recharge on the melt composition is quite straightforward. With an increase in X, strontium concentration decreases and ${ }^{87} \mathrm{Sr} /{ }^{86} \mathrm{Sr}$ increases for all four systems, while with an increase in Mro, strontium concentration increases and ${ }^{87} \mathrm{Sr} /{ }^{86} \mathrm{Sr}$ increases for all four systems.

Overall, in all four systems, 2 stages can be defined (1) strontium concentration initially increases above the initial concentration due to fractionating magma. Since the recharge magma has the same strontium concentration as the initial magma, the recharge will at the same time decrease the strontium concentration (Fig. 4), thus with increasing amount of recharge in the increase of strontium concentration less well defined (used parameters shown in table 2 and 3). (2) Fractional crystallization of feldspar dominates and strontium concentration in the melt decreases. As for stage 1, fractionation (decreases strontium concentration) and recharge (increases strontium concentration) are competing, thus with increasing amounts of recharge, strontium concentration is higher (Fig. 4).

Initially no anatectic melt forms as the country rock still needs to heat up to its solidus temperature and although assimilation does not initially affect geochemistry, heat is being transferred from the magma body to the country rock. When the country rock reaches its solidus, partial melt is produced and a portion (depending on $x: x=0$, no assimilation; $x=1$, all anatectic melt enters the magma body) gets mixed into the magma decreasing the strontium concentration even further, while ${ }^{87} \mathrm{Sr} /{ }^{86} \mathrm{Sr}$ becomes more radiogenic. This is consistent with the compatible nature of strontium in both country rock and magma and with incorporation of more radiogenic assimilant. It is also noteworthy that there is no obvious difference in strontium and ${ }^{87} \mathrm{Sr} /{ }^{86} \mathrm{Sr}$ between systems 1 (initial magmatic strontium concentration 500 - recharge strontium concentration $500 \mathrm{ppm}$ ) and 3 (initial magmatic strontium concentration 500 - recharge strontium concentration $1800 \mathrm{ppm}$ ) and between system 2 (initial magmatic strontium concentration 1800 - recharge strontium concentration $1800 \mathrm{ppm}$ ) and system 4 (initial magmatic strontium concentration 1800 - recharge strontium concentration 500 ppm).

But how reliable are these models? The main problem is that the mathematical functions within the model allow small amounts of country rock being melted below the solidus and being added to the magma body and these additions of course create small deviations of ${ }^{87} \mathrm{Sr} /{ }^{86} \mathrm{Sr}$ between 120, compared to the value that the magma should have if the anatectic melt melted at the solidus of the country rock, the error is therefore small and within typical analytical uncertainty. Still, when the radiogenic isotope ratio of country rocks and uncontaminated magma are very different, deviations will be larger $(\sim 400 \mathrm{ppm})$ than typical analytical uncertainty because small degree of fractional melt have higher concentrations of $\mathrm{Sr}$ in the first increment of melt (Bohrson and Spera, 2007). In spite of higher deviations, they are still small compared to the total result isotope range after the simulation

Another interesting way to look at mixing between the assimilant and the magma are ${ }^{87} \mathrm{Sr} /{ }^{86} \mathrm{Sr}$ and $\delta^{18} \mathrm{O}$ isotopes. Crustal contamination of the magma produces the opposite effect (Fig. ${ }^{5)}{ }^{87} \mathrm{Sr} /{ }^{86} \mathrm{Sr}$ initially stays constant and increases only at higher amount of anatectic melts and $\delta^{18} \mathrm{O}$ increases at 
Chapter 3 - Temporal changes in mantle wedge geometry and magma generation processes in the Central Andes: Towards linking petrological data to thermomechanical models

low amount of anatectic, rather than staying constant. The curves are thus convex (e.g. Davidson et al., 1991; Vroon et al., 1993; Freymuth et al, in revision). Increasing amount of anatectic melt (X) advances the end product further along the mixing trend, but does not change the concavity of the trend.
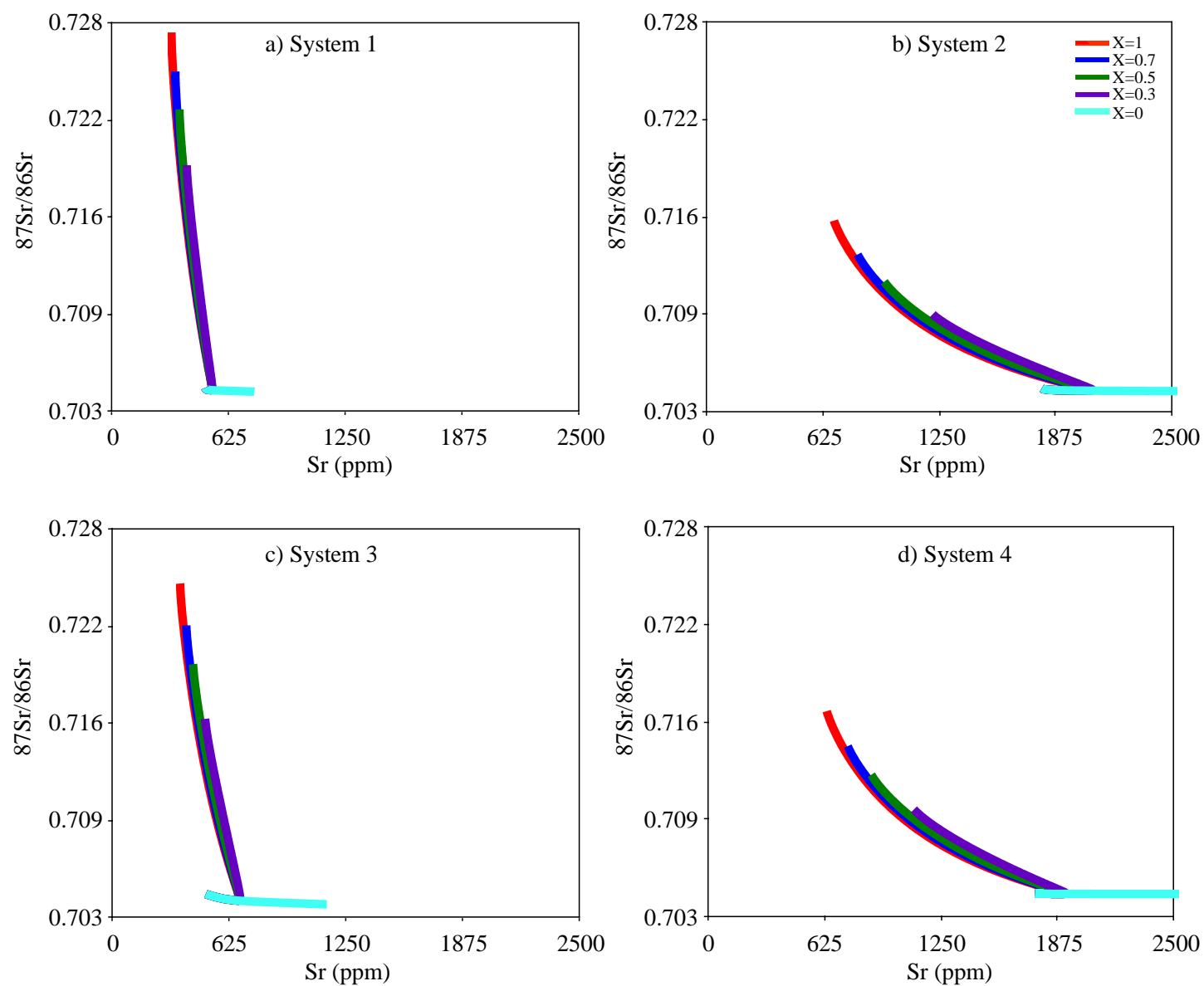

Fig. 3 Comparison of $\mathrm{Sr} \mathrm{vs}^{87} \mathrm{Sr} /{ }^{86} \mathrm{Sr}$ results of EC-RAxFC model calculations with a constant Mro $=0.3$ showing with increasing $\mathrm{X}$ an increase in ${ }^{87} \mathrm{Sr} /{ }^{86} \mathrm{Sr}$ and decrease in strontium for four different systems. System 1: The lower endmember with both initial strontium concentration of the magma and recharge of $500 \mathrm{ppm}$. System 2: The upper limit with strontium concentrations of $1800 \mathrm{ppm}$ in both the magma and recharge conditions. System 3 has a recharge of $1800 \mathrm{ppm}$ and initial magmatic strontium concentration of $500 \mathrm{ppm}$ and on system 4, the recharge magma has a v concentration of $500 \mathrm{ppm}$ and an initial strontium magma concentration of $1800 \mathrm{ppm}$. 
Chapter 3 - Temporal changes in mantle wedge geometry and magma generation processes in the Central Andes: Towards linking petrological data to thermomechanical models

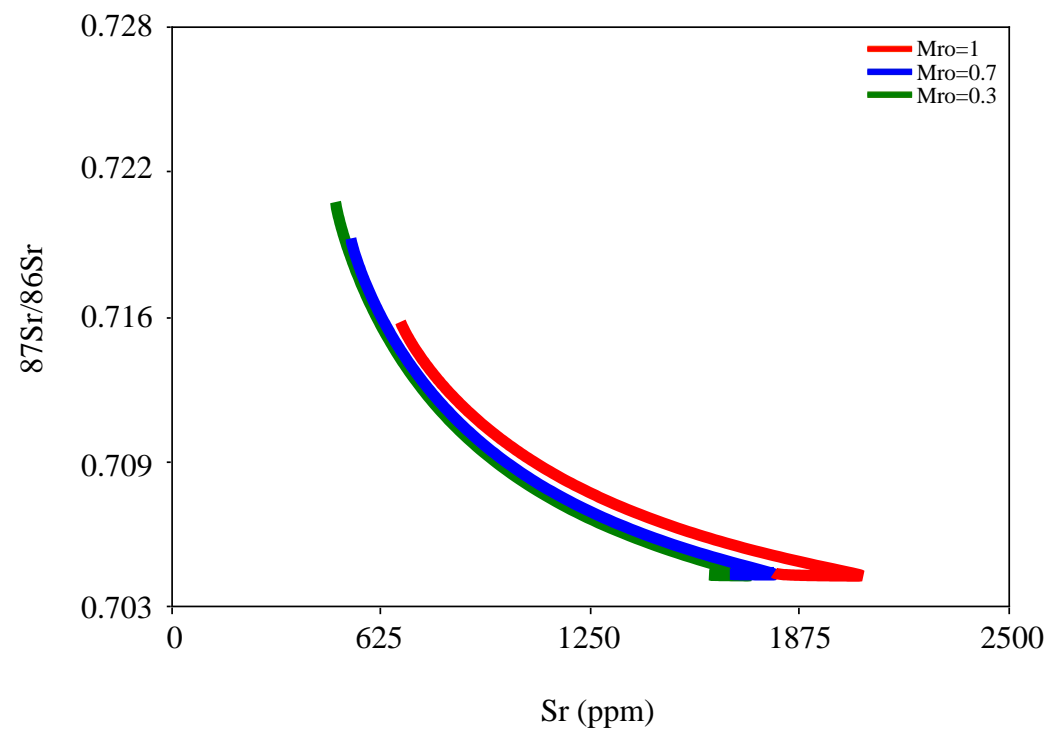

Fig. 4. Sr vs ${ }^{87} \mathrm{Sr} /{ }^{86} \mathrm{Sr}$ for different amount of Mro (recharge) 0.3, 0.7 and 1 for system 2 . The assmimilant has been kept constant at $\mathrm{X}=1$ System 1: The lower endmember with both initial strontium concentration of the magma and recharge of 500 ppm. System 2: The upper limit with strontium concentrations of $1800 \mathrm{ppm}$ in both the magma and recharge conditions. 
Chapter 3 - Temporal changes in mantle wedge geometry and magma generation processes in the Central Andes: Towards linking petrological data to thermomechanical models
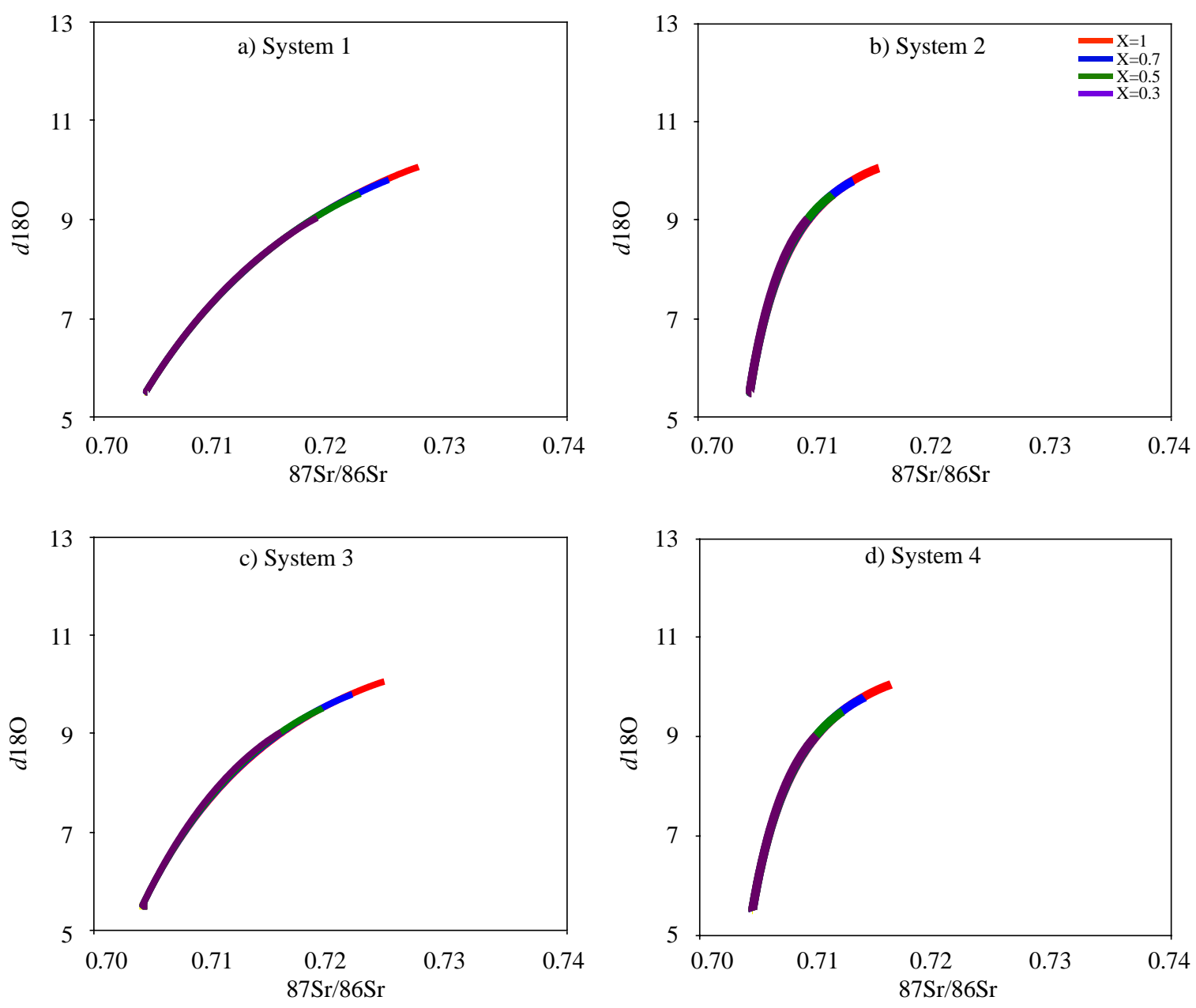

Fig. $5 .{ }^{87} \mathrm{Sr} /{ }^{86} \mathrm{Sr}$ vs $d^{18} \mathrm{O}$ for different amounts of mixing of the anatectic melt with the standing magma comparing four different systems. . System 1: The lower endmember with both initial strontium concentration of the magma and recharge of $500 \mathrm{ppm}$. System 2: The upper limit with strontium concentrations of $1800 \mathrm{ppm}$ in both the magma and recharge conditions. System 3 has a recharge of $1800 \mathrm{ppm}$ and initial magmatic strontium concentration of $500 \mathrm{ppm}$ and on system 4, the recharge magma has a strontium concentration of $500 \mathrm{ppm}$ and an initial strontium magma concentration of $1800 \mathrm{ppm}$.

\subsubsection{Crustal contamination - HREE depletion}

Within the crustal contamination model, besides $\mathrm{X}$ and Mro, all parameters were kept constant and since there are only minor variations for systems 3 and 4 (System 3 has a recharge of $1800 \mathrm{ppm}$ and initial magmatic strontium concentration of $500 \mathrm{ppm}$; system 4, recharge magma with a strontium concentration of $500 \mathrm{ppm}$ and an initial strontium magma concentration of $1800 \mathrm{ppm}$ ) henceforth only system 1 (The lower endmember with both initial strontium concentration of the magma and recharge of $500 \mathrm{ppm}$ ) and system 2 (The upper limit with strontium concentrations of $1800 \mathrm{ppm}$ in both the magma and recharge conditions) will be used unless otherwise noted. I thus compared two different systems indicating large variations with different initial and recharge melt concentrations (500 - 500 and $1800-1800$ strontium ppm respectively). Variations of strontium concentrations of the anatectic melt on the other hand also contribute to variations of melt composition. It is therefore important to 
Chapter 3 - Temporal changes in mantle wedge geometry and magma generation processes in the Central Andes: Towards linking petrological data to thermomechanical models

compare modeled data to experimentally obtained data, not only for strontium and oxygen, but also rare earth elements need to be consistent.

For comparison of the oxygen and strontium data I use the dataset from Freymuth et al. (in revision) and Kay et al., 2010. They show most oxygen values are higher than mantle values, e.g. continental rocks are heavier in $\delta^{18} \mathrm{O}$. Andesitic strontium isotopic ratios have a narrow range compared to ignimbrite values in most Neogene magmas, furthermore a division can be made for the northern Altiplano and the APVC (Altiplano Puna Volcanic Center) ignimbrites, with higher ${ }^{87} \mathrm{Sr} /{ }^{86} \mathrm{Sr}$ isotope values of the APVC suggesting different crustal domains (Mamani et al., 2008; 2010). The magma was thus contaminated by Andean crust of distinct chemical and isotopic compositions implying a difference in crustal thickness (thicker in the south).

For the model I tried to see what the possible chemical ranges are for anatectic melt but also recharge and the pristine melt compositions in order to obtain a representative dataset. To test the anatectic melt composition four different models have been run with strontium concentration of anatectic melt of 250,500, 800 and $1400 \mathrm{ppm}$ for system 1 and 2, while the amount of recharge and anatectic melt are kept constant. For system 1 (Fig.6a), only strontium values lower than $250 \mathrm{ppm}$ for the anatectic melt are reasonable, since most of samples lie above the $250 \mathrm{Sr}$ ppm run (red). This suggests low strontium anatetic melt concentrations, which could be the case for the upper most crust (ignimbrite values $\sim 100$ ppm). For system 1 (Fig. 6a) the maximum value of strontium would than be $250 \mathrm{pmm}$. All strontium concentration higher as $250 \mathrm{ppm}$ in the anatectic melt don't correspond with the measured strontium concentration and isotope values for the andesites or the northern Altiplano and the APVC ignimbrites. System 2 is slightly different (Fig.6b) showing a more representative model for crustal contamination. It seems with system 2 , which are high values, all sample data can be explained by just varying strontium values of the anatectic melt from $250 \mathrm{ppm}$ to $1400 \mathrm{ppm}$. Strontium concentrations of $1400 \mathrm{ppm}$ in an anatectic melt is relatively high, and would suggest a deeper and more mafic crust (Mamani et al., 2010).

Besides modeling $\delta^{18} \mathrm{O}$ and ${ }^{87} \mathrm{Sr} /{ }^{86} \mathrm{Sr}$, also the mass of the melt in magma and anatectic melt added to the magma body is calculated, and thus the amount of contamination can be estimated. I use model 2 (Fig. 6b), due to its better match with analyzed lava samples. Using a strontium concentration within the anatectic melt of $250 \mathrm{ppm}$ (red) the maximum amount of crustal contamination for andesites is $60 \%$, for $500 \mathrm{ppm} 45 \%$ (orange), for $80033 \%$ (blue) and for $1400 \mathrm{ppm}$ strontium a maximum of $28 \%$ crustal contamination is calculated (green). However all these values seem to be overestimated. 

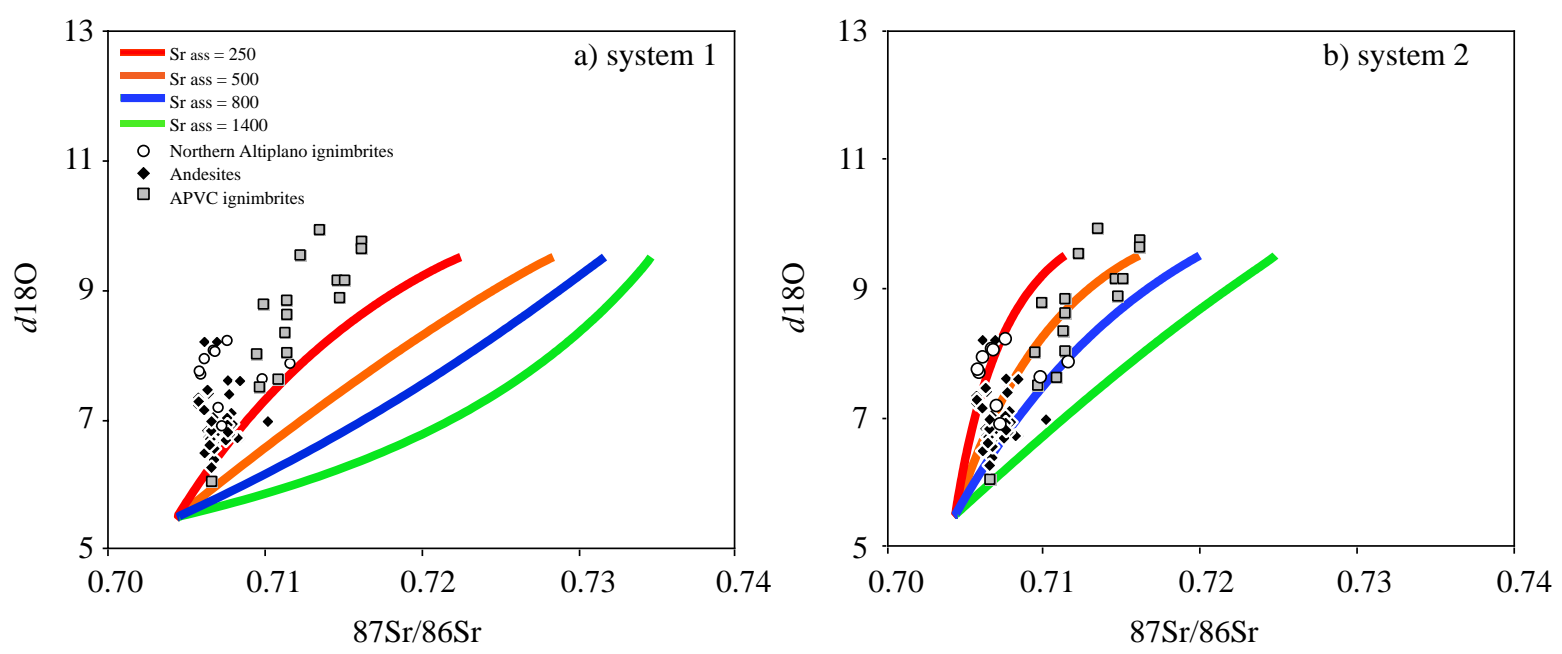

Fig. 6. Oxygen and $\mathrm{Sr}$ isotope variations in Central Andean ignimbrites compared to stratovolcanoes and the EC-RAxFC model. (a) System 1: The lower endmember with both initial $\mathrm{Sr}$ concentration of the magma and recharge of $500 \mathrm{ppm}$. (b) System 2: The upper limit with Sr concentrations of $1800 \mathrm{ppm}$ in both the magma and recharge conditions. Sr ass = strontium concentration used in the anatectic melt. Andesites (Mamani et al., 2008), Northern Altiplano ignimbrites (Freymuth and Wörner, InRev) APVC ignimbrites (Kay et al., 2010). Mro = amount of recharge relative to the initial mass of the pristine magma and $\mathrm{X}$ is the amount of anatectic melt relative to the initial mass of the pristine magma are kept constant; Mro $=0.3$, $\mathrm{X}=0.5$.

Now it is important to see how both models correspond to other elements. The model itself allows 3 additional elements ( $\mathrm{Sm}, \mathrm{Yb}$ and $\mathrm{Y}$ ) to be involved in the calculation. As for strontium and oxygen, I choose for the elements a representative database created by Mamani et al., 2010). They and other authors (Davidson and de Silva, 1992, 1995; Davidson et al., 1991; Kay et al., 1987; 1994, 1996; Wörner et al., 1988, 1992, 1994) show that HREE and Y depletions relate to the crustal structure and evolution of the Central Andean orocline. Since $\mathrm{Sr} / \mathrm{Y}$ ratios are sensitive to plagioclase fractionation it is also important to look at $\mathrm{Sm} / \mathrm{Yb}$ that are less affected by fractionation processes.

To model $\mathrm{Sr} / \mathrm{Y}$ vs $\mathrm{Sm} / \mathrm{Yb}$ based on geochemistry data is challenging due to its dependency on many parameters. For all four elements good constraints are needed on the chemical composition of the initial magma, recharge magma and the assimilant and of course there is a strong dependency on the amount of recharge (Mro) and anatetic melt (X). Figure 7 shows again the two different systems, however unlike the $\delta^{18} \mathrm{O},{ }^{87} \mathrm{Sr} /{ }^{86} \mathrm{Sr}$ data (Fig. 6) the model seems to give unrealistic values for system 2, while system 1 fits here much better. In spite of a relative good correlation of system 1 with $\mathrm{Sr} / \mathrm{Y}$, $\mathrm{Sm} / \mathrm{Yb}$ and system 2 with $\delta^{18} \mathrm{O},{ }^{87} \mathrm{Sr} /{ }^{86} \mathrm{Sr}$, it seems that the two extremes do not give a good representation the evolution of $\delta^{18} \mathrm{O},{ }^{87} \mathrm{Sr} /{ }^{86} \mathrm{Sr}$ isotopes and $\mathrm{Sr}, \mathrm{Y}, \mathrm{Sm}$ and $\mathrm{Yb}$ trace elements. Both models are thus unreliable and consequently the models cannot track the presence of higher-pressure minerals as amphibole and garnet in the lower crust, which might have suggested that crustal thickness has grown through time. However both systems show (with exception of assimilant composition with 
Chapter 3 - Temporal changes in mantle wedge geometry and magma generation processes in the Central Andes: Towards linking petrological data to thermomechanical models

Sr $250 \mathrm{ppm}$ ), as for the database samples, an increase in $\mathrm{Sm} / \mathrm{Yb}$ (with time, as shown by Mamani et al., 2010) and reflect increasing lithostatic pressure where differentiation and crustal assimilation take place and is thus indirectly a consequence of crustal thickening. It should be noted that low $\mathrm{Sm} / \mathrm{Yb}$ ratios did occur at any given time, demonstrating that low-pressure signatures continued even after the crust had significantly thickened. Aside from an increase in crustal thickness, seen as HREE depletion through time, there are of course many factors involved such as the depth and amount of assimilation, which is again related to temperature and composition of magma, country rock, and recharge magma. Additionally magma mixing plays an important role. These factors are schematically demonstrated in Fig.7 with respect to $\mathrm{Sr} / \mathrm{Y}$ and $\mathrm{Sm} / \mathrm{Yb}$ ratios. Low $\mathrm{Sr} / \mathrm{Y}$ and $\mathrm{Sm} / \mathrm{Yb}$ ratios characterize stability of clinopyroxene and/or amphibole, whereas high $\mathrm{Sr} / \mathrm{Y}$ and low $\mathrm{Sm} / \mathrm{Yb}$ suggest garnet bearing and plagioclase free (ecolgite) residues. The models conversely show rather a decrease in $\mathrm{Sr} / \mathrm{Y}$ values after $\mathrm{Sm} / \mathrm{Yb}>4$ suggesting a more felsic crust and the fractionation of plagioclase.
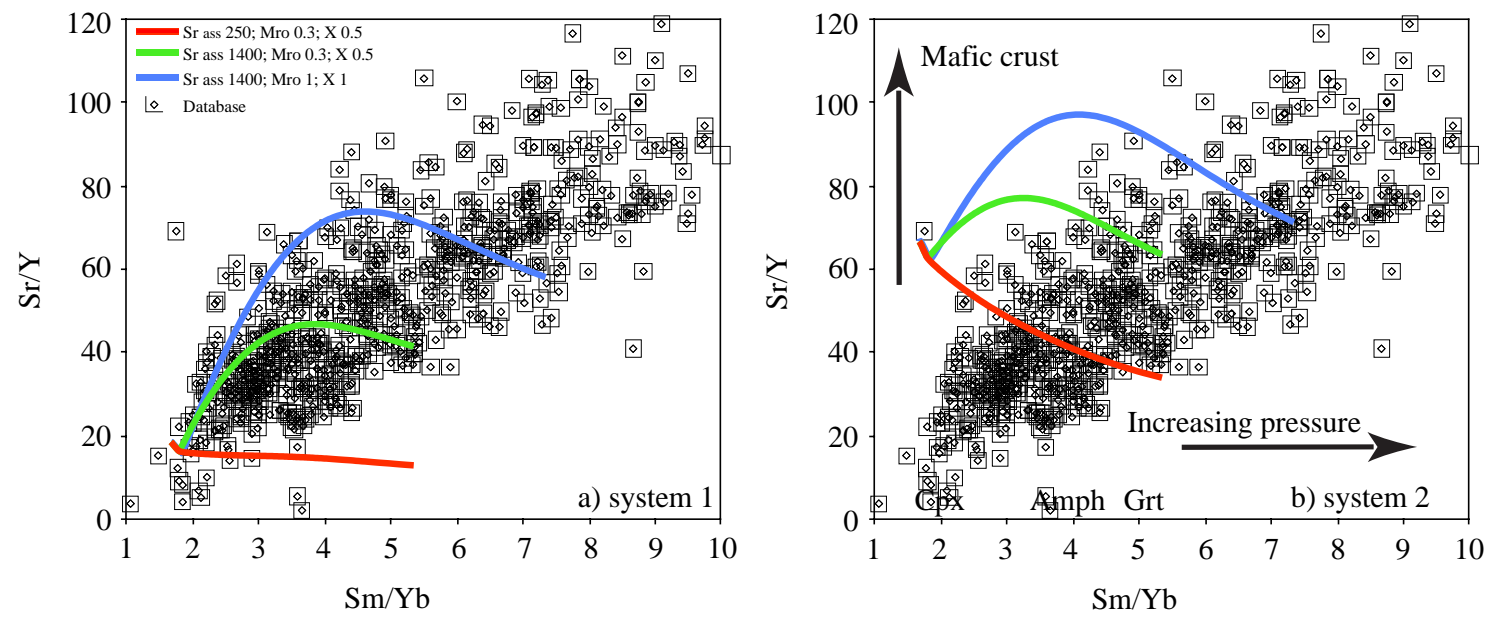

Fig.7. $\mathrm{Sr} / \mathrm{Y}$ and $\mathrm{Sm} / \mathrm{Yb}$ variations for all lava samples < $23 \mathrm{Ma}$ in the Central Andes. (a) System 1: The lower endmember with both initial $\mathrm{Sr}$ concentration of the magma and recharge of $500 \mathrm{ppm}$. (b) System 2: The upper limit with $\mathrm{Sr}$ concentrations of $1800 \mathrm{ppm}$ in both the magma and recharge conditions. Sr ass = strontium concentration used in the anatectic melt. Mro = amount of recharge relative to the initial mass of the pristine magma; $\mathrm{X}$ is the amount of anatectic melt relative to the initial mass of the pristine magma. Sr/Y and Sm/Yb values are based on Farmer, 2004; Rudnick and Gao, 2004; Plank and Langmuir 1998.

As indicated by Fig. 6 and 7 a model reconstruction is not easy and still needs some finetuning. The main problem lies with the thick Andean crust (up to $80 \mathrm{~km}$ ), upper crustal compositions based on Farmer, 2004; Rudnick and Gao, 2004 and Plank and Langmuir 1998 are therefore probably incorrect for an estimation of the Andean crust. Accessing the Andean database and trial and error (Table 4) give slightly better estimates than shown by Fig. 8. Unfortunately, none of the runs gives an unambiguous solution for all modeled isotopes. Changing thermal parameters has the same effect on 
Chapter 3 - Temporal changes in mantle wedge geometry and magma generation processes in the Central Andes: Towards linking petrological data to thermomechanical models

composition as changes in $\mathrm{X}$ and Mro and thus does not provide a solution - therefore the EC-RAxFC model is unable to explain all chemical features.

At present it is not possible to identify a single parameter responsible for the mismatch between models and analyzed samples, but it does indicate that the Central Andes is unique place where even more complicated chemical models do not seem to work. The EC-RAxFC model takes recharge, assimilation and mixing (recharge, pristine magma and assimilant) into consideration, however Banaszak (2014) showed there are 3 different end members mixing needed in order to explain the chemical compositions (mostly andesites) of lava samples, a level of complexity that cannot be adequately accommodated by current models.

In a relatively new study by Bohrson et al., 2014 the capabilities of EC-RAxFC have been combined with MELTS. The so called Magma Chamber Simulator is a computational tool that tracks enthalpies, composition of both major, trace elements and isotopes and temperatures of melt, fluid and solids, however this model is still in development and might in the future be able to improve the modeling of trace element signatures in the Central Andes.
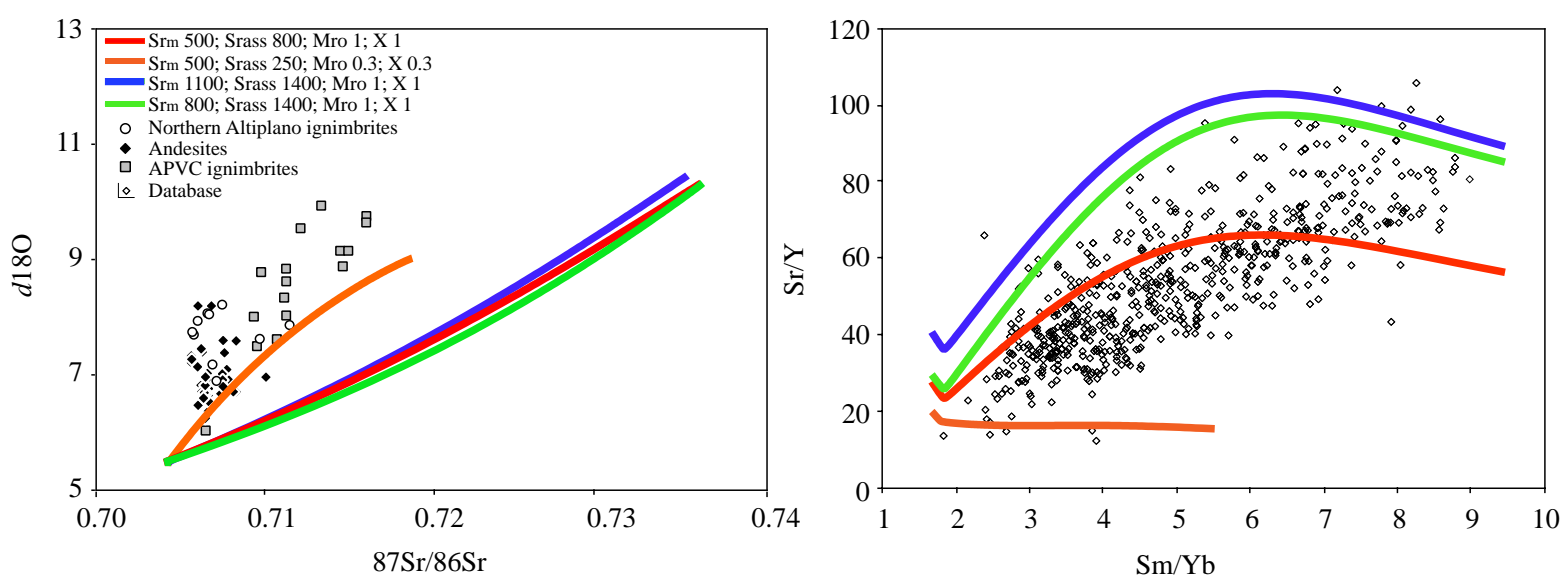

Fig. $8 .{ }^{87} \mathrm{Sr} /{ }^{86} \mathrm{Sr}$ vs $d^{18} \mathrm{O}$ and $\mathrm{Sr} / \mathrm{Y}$ and $\mathrm{Sm} / \mathrm{Yb}$ variations for all lava samples $<23 \mathrm{Ma}$ in the Central Andes. Figure similar to Fig. 6 and 7 but using different parameters. See table (4). Mro = amount of recharge relative to the initial mass of the pristine magma; $\mathrm{X}$ is the amount of anatectic melt relative to the initial mass of the pristine magma. Srm $=$ used strontium concentration in the pristine magma and recharge magma; Srass = used strontium concentration for the assimilant.

\subsection{Evaluation of Andean orogeny models}

The uplift history of the Altiplano started at approximately $60 \mathrm{Ma}$, at sea level (Sempere et al., 1997). Based on paleoelevation approximations from crustal shortening (Isacks, 1988; Masek et al., 1994) and the Chucal and Jakokkota floras (Marshall et al., 1993; Charrier et al., 1994; Munoz and Charrier, 1996), the plateau reached about $25 \%-30 \%$ of its modern elevation in the early Miocene. 
Chapter 3 - Temporal changes in mantle wedge geometry and magma generation processes in the Central Andes: Towards linking petrological data to thermomechanical models

By $10 \mathrm{Ma}$ the uplift was no more than $50 \%$ of its modern elevation. The uplift then increased to higher rates in the last $10 \mathrm{Ma}$, lifting the Altiplano and Eastern Cordillera up by 2300 to $3500 \mathrm{~m}$ (Van der Hammen et al., 1973; Kennan et al., 1997) and because the Altiplano has experienced little erosion since the Miocene, it can be assumed that most of the rock uplift represents surface uplift.

Most estimates of crustal thickness range between 59 and $80 \mathrm{~km}$ beneath the Western and Eastern Cordilleras and Altiplano, with an average value of $70 \mathrm{~km}$ (Cunningham and Roecker, 1986; Zandt et al., 1994; Beck et al., 1996; Myers et al., 1998; Baumont et al., 2001; Beck and Zandt., 2002; Yuan et al., 2002; McGlashan et al., 2008; Lloyd et al., 2010). The crust in the Altiplano is isostatically balanced through crustal thickening (Whitman et al., 1993) and the crustal shortening due to compression generated by plate coupling contributes to a significant amount of the crustal thickness (Kley and Monaldi, 1998; Gotberg et al., 2010). Gotberg et al., (2010) modeled a required 240 - 300 $\mathrm{km}$ of shortening to explain the $70 \mathrm{~km}$ of thickness in the Andes. Other important mechanisms that can contribute to crustal thickening are magmatic additions or shortening that are covered by the volcanic arc (Gotberg et al., 2010), thermal weakening or underthrusting of the Brazilian shield (Whitman et al., 1993). Multiple thermo-mechanic models explaining the evolution of the Central Andes are evaluated below.

\subsubsection{Upper plate conditions}

A critical part of modeling is the issue of timing. The age of the ignimbrite activity in the APVC implies that at approximately $10 \mathrm{Ma}$ the anomalous thermal structure of the crust in the region was established. The timing of tectonic shortening, the passage of the Juan Fernandez Ridge and the steepeining of the slab after its passage are less well defined in time. For a good time constraint on the tectonic shortening, it is essential to find the relationship of tectonic shortening to the thermal state of the crust, and examine the cause of the crustal heating. One model investigating this is by Babeyko et al., 2002. Several causes that must be considered for crustal heating are: (1) increased radiogenic heating caused by crustal thickening, (2) shear heating due to deformation, (3) heating by intrusion of magma and (4) heating as a result of increased mantle heat flow at the base of the crust due to asthenospheric upwelling.

Shear heating can explain an increase in crustal temperatures and the onset of magmatism in strikeslip shear zones earlier in the collision history. Even though the temperature increase might be minor, shear heating might be able to induce strain localization, leading to additional heat needed to produce partial melting (Leloup et al., 1999; Kincaid and Silver, 1996). However, Babeyko et al., 2002 show in a 2D model that the middle crust becomes actually colder during stacking of the crust because cold crust is thrust below hot crust. The result is a downward displacement of the isotherms and a shallowing of the temperature gradient with depth. This may overshadow the effects of the heat produced from both radiogenic and shear heat sources. Even though the abundance of radiogenic 
Chapter 3 - Temporal changes in mantle wedge geometry and magma generation processes in the Central Andes: Towards linking petrological data to thermomechanical models

elements within the crust per unit surface area increases due to crustal thickening the overall temperature increase due to radiogenic heating at $20-25 \mathrm{~km}$ depth is extremely slow and after $15 \mathrm{Myr}$ of shortening is less than a few tens of degrees (Babeyko et al., 2002).

Shear heating is even less important within their model and is smaller than the radiogenic heat production (Babeyko et al., 2002). High strain rates are highest at fault zones in the upper and middle crust and is a region with lower crustal flow, While in the upper crust and the uppermost mantle high stresses occur outside the fault zone. Shear heating is therefore more pronounced but locally restricted within fault zones in the brittle upper crust and in the mantle just below the Moho and is less effective in the ductile lower crust.

Before the model by Babeyko et al. (2002) the idea of partial melting in a thickening crust was thought to be due to heating from intruding magmas from the mantle wedge with large volume ignimbrites being the consequence in some areas (de Silva, 1989, Laube and Springer, 1998). The model of Babeyko et al., 2002 is more advanced as a fully thermomechanical model including active deformation and internal heating, but did not include advective heat by magma intruding into the crust from the mantle. However magma ascending to a depth of $25-20 \mathrm{~km}$ into the middle crust with observed plutonic dimensions with lengths varied from 0.5 to $5 \mathrm{~km}$ and the thicknesses varied from 50 to $500 \mathrm{~m}$ (after McCaffrey and Petford 1997) show, similar to the radiogenic and shear heating, only minor temperature increase (approx. $100{ }^{\circ} \mathrm{C}$ ) even at a maximum magmatic input of $60 \mathrm{~km} / \mathrm{Ma} / \mathrm{km}$. If the magma input rate into the crust is too low (less than $60 \mathrm{~km} / \mathrm{Ma} / \mathrm{km}$ ) the intrusions will cool faster than the crust has time to heat up.

The partial melting model by Babeyko et al., 2002 uses the relationship between melt fraction and temperature found in experiments on vapor free melting of felsic muscovite biotite and biotite gneisses (Gardien et al., 1995). Melt accumulation and subtraction is modeled using the model of percolation thresholds (Petford et al., 2000; Vigneresse et al., 1996). The melt leaves the rock matrix when its fraction exceeds the second percolation threshold and is entirely intruded into the $20-25 \mathrm{~km}$ magma reservoir. The procedure continues until the melt fraction in the lower crustal reservoir falls below the first percolation threshold. Using crustal convection the middle crust increases in temperature to an average of around $700{ }^{\circ} \mathrm{C}$ within $10-20 \mathrm{My}$ after initiation of tectonic shortening due to asthenospheric upwelling and magmatic underplating. Furthermore, the model shows that partially molten lower crustal material is advected into the middle crust through narrow channels and then spreads laterally. Thus convection increases the temperatures in the middle crust to near solidus conditions.

\subsubsection{Plume induced crustal convection}

Gerya (2014) presents a new 3D thermomechanical model based on the mantle plume movement into warm and thin lithosphere on Venus. Even though the tectonic (much warmer lithosphere and 
Chapter 3 - Temporal changes in mantle wedge geometry and magma generation processes in the Central Andes: Towards linking petrological data to thermomechanical models

thinner crust) and chemical (mafic crust) setting is not comparable to the Central Andes, the model gives us some insights into the convection within the crust. On Venus pre nova (nova are radially fractured centers, $100-300 \mathrm{~km}$ in diameter) is characterized by the plume lithosphere interaction and produces surface uplift. Heat loss from the plume leads to intense lower crustal melting. The buoyancy of the melt then initiates a localized crustal convection cell that pierces and fractures the thin brittle upper crust, consequently leading to focused surface uplift at the center. Thus unlike the 2D model of Babeyko et al., 2002 it seems magma intrusions can have, on a local scale, a major influence on convection within the crust and therefore uplift as well.

\subsubsection{Mantle wedge and slab geometry}

Using the thermo-mechanical, numerical modeling of the dynamic interaction between subducting and overriding plates, the model of Sobolev et al., (2006) examines the factors that control the intensity of the tectonic shortening. The model is based on the initial crustal structures expected for the Central and Southern Andes at $35 \mathrm{Ma}$ with a thick (40 - $45 \mathrm{~km})$ felsic upper crust and thinner, mafic, lower crust. The crustal thickness thus assumes an already significant amount of crustal shortening. However, earlier subduction history may be crucial to understanding the evolution of the Central Andes since subduction has been taking place since the Jurassic (Rogers and Hawkesworth, 1989; Pichowiak et al., 1990; Lucassen and Thirlwall, 1998). Besides, a crustal thickness of 40- $45 \mathrm{~km}$ at 35 Ma seems a bit thick since crustal thickening started at around $25 \mathrm{My}$ ago (Isacks, 1988). For the lithosphere a relatively thin $100-130 \mathrm{~km}$ was chosen. The slab dip remained consistent to the present day in the Central Andes. The movement of the overriding plate and subduction were created by pushing the overriding plate at its boundary and by pulling the slab from below and the obtained velocities were taken from plate tectonic reconstructions after Somoza, 1988; Silver et al., 1998. The surface temperature in the Sobolev et al., (2006) - model was kept constant at $0{ }^{\circ} \mathrm{C}$ and at the lower boundary at $1350{ }^{\circ} \mathrm{C}$, no horizontal heat flow was taken into consideration. The variable parameter within the model is the friction coefficient in the subduction channel. Using a friction coefficient of 0.05 the model shows that $58 \%$ of the westward drift of South America is accommodated by trench roll-back, tectonic shortening, $37 \%$ and subduction erosion $5 \%$ of the South American margin.

From the model, constrained by geological and geophysical observations, the most important factor controlling the intensity of the tectonic shortening was the fast and accelerating (from 2 to $3 \mathrm{~cm} \mathrm{yr}^{-1}$ ) westward drift of the South America Plate, also an increase in compression stress in the overriding plate is observed when the subduction angle is decreases, whereas possible increase in the subduction rate does not intensify shortening in the overriding plate. The lack of correlation between the convergence rate and the shortening rate can be explained by the roll back of the trench due a negative buoyancy driven by slab pull, since an increase in subduction rate also leads to an increase in trench roll-back (Christensen, 1996). However others (Yanez and Cembrano, 2004) suggested that the 
Chapter 3 - Temporal changes in mantle wedge geometry and magma generation processes in the Central Andes: Towards linking petrological data to thermomechanical models

development of the Andes was favored by the reduction of convergence rate. Their model shows a stronger inter-plate coupling due to the older subducting plate at the trench and the slow down in the convergence velocity, implying larger downward bending and extension of the forearc region and at the same time larger compression in the arc-foreland region

Other important factors are the crustal structure of the overriding plate, since the middle lower crust is generally weak and felsic in composition. Consequently high stresses created by the tectonic shortening in the curst cannot be maintained. Another important factor within the model is delamination of the mantle lithosphere and mafic lower crust. During crustal thickening pressure regimes change within the crust and within the mafic lower crust garnet is formed, leading to an overall density increase. Therefore the denser fragments of the crust and mantle tend to descend into the asthenosphere. The cool, delaminated material in turn blocks the asthenosphere wedge and increases viscous coupling between the plates. However in Southern Peru and the Altiplano region no magmatic products of typical delamination processes are found (Hartely et al., 2007). Besides in order to allow delamination to occur significant amounts of crustal thickening should have heralded to allow density instabilities.

The main problems with this model is (1) only the last $35 \mathrm{Ma}$ of subduction evolution were considered, although earlier subduction history may be crucial for understanding the Andean orogeny; (2) Fluid flow is neglected in this model, including the fluids will create changes in the upward fluid flow and lead to different thermal states of the mantle and crust (Wilson et al., 2014); (3) There are no constrains on the upper crustal thermal state through time. Crustal convection cells and advection may lead to an increase in uplift as well and thus need to be considered (Gerya, 2014); (4) 3D model is needed in order to model the corner flow of the asthenosphere. Especially flat subduction is hard to model in $2 \mathrm{D}$ because the slab gets pulled into the crust due to the lack of corner flow of the asthenosphere.

\subsubsection{Fluid flow}

It is well known that fluids play a crucial role in subduction evolution. For example, excess mechanical weakening along tectonic interfaces, due to excess fluid pressure, may enable oceanic subduction. Hence, the fluid content seems to be a critical parameter for subduction initiation. Studies have also shown a correlation between the location of slab dehydration and intermediate seismic activity. Furthermore, expelled fluids from the subduction slab affect the melting temperature, consequently, contributing to partial melting in the wedge above the down- going plate, and resulting in chemical changes in earth interior and extensive volcanism. Fluids thus have a great impact on tectonic processes and therefore should be incorporated into geodynamic numerical models. However, this is what most of the thermomechanical subduction models still lack. One major problem is that most subduction models either disregard fluid transport or use buoyancy driven estimates (Cagnioncle 
Chapter 3 - Temporal changes in mantle wedge geometry and magma generation processes in the Central Andes: Towards linking petrological data to thermomechanical models

et al., 2007; Wada et al., 2011). A new subduction model by Wilson et al., 2014 includes the fluid flow and is based on older models after Syracuse et al., 2010 and van Keken et al., 2011.

Pressure gradients, caused by variations in fluid flux interacting with the permeability and viscosity structure of the solid mantle are extremely important within the model. When these gradients are ignored high permeability systems are controlled by buoyancy and fluid flow is mainly vertical. However, when pressure gradients are built-in, compaction pressure has three different effects: (1) enhancement of upslope flow within high permeability layers in the slab caused by local dehydration reaction, (2) deflection of fluids along the sloping rheologically strengthening region in the upper thermal boundary layer and (3) production of nonlinear porosity waves that locally control the flow of fluids and can allow significant temporary accumulation of fluids. Estimates of compaction pressures inserted to thermomechanical models can explain about $10 \%$ of the flux melting.

\subsection{Towards linking petrological data to thermomechanical models}

The most important observations from petrological data from the Miocene to Quaternary are: no change in the final crystallization pressures and temperatures through time for andesites; magmatic system gets slower trough time; decrease in effusion rates; increase in eruption rates and increase in magma production (see chapter 2 and above). Besides the sequence of distinct magmatic regimes (plateau-ignimbrites, shield andesites and evolved stratovolcanoes) is diachronous during the past 26 Ma of Central Andean evolution with age's younging from north to south. So how can these findings be linked to thermomechanical models?

The first stage of deformation and uplift are well documented after $26 \mathrm{Ma}$. Big ignimbrite eruptions occurred in the wake of the subducting Juan Fernadez Ridge; a period of steepening slab ( 22 Ma and $\sim 14 \mathrm{Ma}$ ), with large-scale melting of the conditioned crust (Sandeman, 1995; Yanez et al., 2001; Kay and Coira, 2009). Backward migration of the arc is reflected in local pyroclastic eruptions and stratovolcanoes of Huaylillas (24-10 Ma) and Barroso age (6-3 Ma). After 14 to $10 \mathrm{Ma}$ another stage of uplift occurred, documented by high incision rates (Thouret et al., 2007). Due to this immense uplift the magmas of Quaternary age intrude and traverse trough a continental crust up to 70 $\mathrm{km}$, while for Miocene magmas the ascend trough the crust was much shorter (Mamani et al., 2010), and can explain the slower magmatic system during Quaternary times and subsequently lead to an decrease in effusion rate (Chapter 2). By itself it might seems contradictory that an increase in eruption rate can occur at the same time as a decrease in effusion rate and slowing down of the magmatic system. However combining slab steepening, an increase in heat input and subsequently an increase of crustal melting the increase in eruption rates with age can be explained, while the increase in eruption rate from north to south can partly be explained by the thicker crust itself, since with crustal thickening the system is warmer and less energy is requiring for melting. 
Chapter 3 - Temporal changes in mantle wedge geometry and magma generation processes in the Central Andes: Towards linking petrological data to thermomechanical models

After the period of flat subduction (e.g. passing of the Juan Fernandez Ridge) the overall increasing thermal input along with ongoing arc magmatism and crustal thickening thermally prepared the crust (elevated geotherm), resulting in extensive crustal melting. Additionally the renewed asthenospheric mantle flow created melting above the steepening slab. ), and increase in volatile flux in the mantle wedge and delamination (Isacks, 1988; Bird, 1979; Kay and Kay, 1993, Kay et al., 1995) could have increased the heat flux. Besides the overall increase in heat flow over time, the increase of magma intrusions promotes convection within the crust (Gerya, 2014). This is also the main difference between the models by Babeyco et al. (2002) and Gerya (2014) that intrusions can, on a local scale, have a major influence on convection within the crust. Buoyancy of molten rocks initiates a localized crustal convection cell, which pierces the crust. From the thermomechanical models it is thus clear that an enhanced heat flow can significantly increases crustal temperatures, prompting the weakening of the crust and enhancing crustal thickening (Babeyko et al., 2002; Gerya, 2014). When taking this aspect into consideration the timing between crustal thickening, slab steepening, heat input and crustal melting should be much less as previous assumed in the above-mentioned thermomechanical models.

One important constraint which is still lacking for linking petrology to any thermomechanical model is the amount of mantle magma vs crustal magma (crustal contamination). The EC-RAxFC model gives ranges between 30 to $60 \%$ of crustal contamination, while the best model by MELTS a value of $20 \%$ of crustal contamination was obtained, but as shown above these values are highly unreliable since both thermodynamic models do not ensue the magmatic evolution within a thick crust. Thus in the future the amount of crustal and mantle magma still need to be better thermodynamically constrained trough time in order to link petrological data to thermomechanical models.

Since none of the previous models linked petrological data, thermo- and baro- and hygrometry data to the thermomechanical observations. I do believe, when combing all of the data, these models can be much more accurate. Since no model exists for the Central Andes which combines, 3D modeling, fluid flow, effect of magma intrusions, upper crustal conditions for the last $80 \mathrm{Ma}$ it is likely that all models have incorrect constraints on timing of events. It is therefore very possibly with combing these matters might then lead to a much faster uplift, crustal heating and melting than previous assumed

\subsection{Conclusions}

I have tested the hypothesis that chemical differences in magmas through time are caused by crustal thickening. Unfortunately existing codes of conventional igneous geochemical models (MELTS and EC-RAxFC) cannot explain yet all variations of andesite compositions. It is therefore challenging to model any chemical variations through time in the Central Andes. The problem probably lies with the complicated magmatic evolution in the Central Andes that cannot be adequately 
Chapter 3 - Temporal changes in mantle wedge geometry and magma generation processes in the Central Andes: Towards linking petrological data to thermomechanical models

captured by these models. The large amount of crustal contamination, mixing of different end members at different levels, recharge and eruption all play a major role on magma composition and thus the initial magma composition cannot be simply used to model differentiation and assimilation alone. On the other hand it is clear that the timing of volumes and eruption rate of andesites can be linked to the structural and thermal state of the Andean crust based on the obvious north to south younging of the large-volume magmatism and an overall increase in eruption rate trough space and time.

While many observations in the Central Andes can currently be explained, still answers to many questions remain open or are unclear. Better models integrating both geochemical and thermomechnical aspects of arc volcanism, that combine petrological data together with fluid flow and convection within the upper crust in a 3D model are needed. 
Chapter 3 - Temporal changes in mantle wedge geometry and magma generation processes in the Central Andes: Towards

\section{References Cited}

Allmendinger RW, Jordan TE, Key SM, Isacks B (1997) The evolution of the Altiplano Puna plateau of the Central Andes: Annu Rev. Earth Planetary. Sci 25:139-174

Allmendinger RW, Gubbels T (1996) Pure and simple shear plateau uplift, Altiplano- Puna, Argentina and Bolivia. Tectonophysics 259: 1-13

Arriagada C, Roperch P, Mpodozis C, Cobbold PR (2008) Paleogene building of the Bolivian Orocline: Tectonic restoration of the central Andes in 2-D map view. Tectonics 27 (TC6014). doi: 10.1029/2008TC002269

Babeyko AY, Sobolev SV, Trumbull RB, Oncken O, Lavier LL (2002) Numerical models of crustalscale convection and partial melting beneath the Altiplano-Puna plateau: Earth Planet. Sci. Lett. 199: $373-388$

Baby P, Rochat P, Mascle G, Hérail G (1997) Neogene shortening contribution to crustal thickening in the back arc of the Central Andes: Geol. 25: 883-886

Banaszak M (2014) Differentiation regimes in the Central Andean magma systems: case studies Taapaca and Parinacota volcanoes, Northern Chile. GAU, University of Göttingen

Baumont D, Paul A, Zandt G, Beck SL (2001) Inversion of Pn travel times for lateral variations of Moho geometry beneath the central Andes and comparison with the receiver functions, Geophys. Res. Lett. 28 (9): 1663-1666

Beck SL, Zandt G (2002) The nature of orogenic crust in the central Andes: J. Geophys. Res. 107: 2230

Beck S, Zandt G, Myers S, Wallace T, Silver P, Drake L (1996) Crustal-thickness variations in the central Andes, Geol. 24 (5): 407-410

Bird P (1978) Stress and temperature in subduction zones: Tonga and Mariana: Geophys. J. R. Astron. Soc. 55: 411-434

Bohrson W.A, Spera F.J (2001) Energy-constrained open-system magmatic processes II: Application of energy-constrained assimilation-fractional crystallization (EC-AFC) model to magmatic systems. J. Petrol. 42:1019-1041

Bohrson WA, Spera FJ (2003) Energy-constrained open-system magmatic processes IV: Geochemical, thermal and mass consequences of energy-constrained recharge, assimilation and fractional crystallization (EC-RAFC). Geochem. Geophys. Geosys. 4, doi:10.1029/2002GC00316 
Chapter 3 - Temporal changes in mantle wedge geometry and magma generation processes in the Central Andes: Towards linking petrological data to thermomechanical models

Bohrson WA, Spera FJ (2007) Energy-constrained recharge, assimilation, and fractional crystallization (EC-RAxFC): A Visual Basic computer code for calculating trace element and isotope variations of open-system magmatic systems. Geochem. Geophys. Geosys. 8: Q11003, doi:10.1029/2007GC001781

Bohrson WA, Spera FJ, Ghiorso MS, Brown GA, Creamer JB, Mayfield A (2014) Thermodynamic model for energy-constrained open-system evolution of crustal magma bodies undergoing simultaneous recharge, assimilation and crystallization: the magma chamber simulator. J. Petrol. 55 (9): 1685-1717

Brandmeier M (2014) A remote sensing and geospatial statistical approach to understating distribution and evolution of ignimbrites in the Central Andes with a focus on Southern Peru. GAU, University of Göttingen

Cagnioncle AM, Parmentier EM, Elkins-Tanton LT (2007) Effect of solid flow above a subducting slab on water distribution and melting at convergent plate boundaries. J Geophys Res 112: B09402

Charrier R, Muñoz N, Palma-Heldt, S (1994) Edad y contenido paleofloristico de la Formación Chucal y condiciones paleoclimaticas para el Oligoceno tardio-Mioceno inferior en el Altiplano de Arica, Chile, in Proceedings, Congreso Geológico Chileno, 7th: Concepción, Chile 1:434-437

Christensen UR (1996) The influence of trench migration on slab penetration into the lower mantleEarth Planet Sci Lett 140 (1-4): 27-39

Coira B, Mahlburg K, Viramonte J (1993) Upper Cenozoic magmatic evolution of the Argentine Puna- A model for changing subduction geometry. Int. Geol. Rev. 35: 677- 720.

Cunningham P, Roecker S (1986) Three-dimensional P and S wave velocity structures of southern Peru and their tectonic implications, J. Geophys. Res. 91 (B9): 9517-9532

Davidson J, Harmon RSH, Wörner G (1991) The source of Central Andean magmas; some considerations. In: Harmon, Rapela (Eds.), Andean Magmatism and its Tectonic Setting, Geol. Soc. Am. Special Publication, 265: 233 - 243

Davidson JP, de Silva SL (1995) Late Cenozoic magmatism of the Bolivian Altiplano. Contrib. Mineral. Petrol. 119: 387 - 408

Davidson JP, De Silva SL (1992) Volcanic rocks from the Bolivian Altiplano: Insights into crustal structure, contamination, and magma genesis in the central Andes. Geol. 20: 1127- 1130

De Silva SL, Francis PW (1989) Correlation of large ignimbrites; two case studies from the Central Andes of northern Chile. J Volcano Geotherm Res 37:133-149

Farmer GL (2004) Continental Basaltic Rocks. In: Treatise on Geochemistry. Holland, H.D. and Turekian, K.K. (Editors), Elsevier, Amsterdam. 3: 85-121 
Chapter 3 - Temporal changes in mantle wedge geometry and magma generation processes in the Central Andes: Towards linking petrological data to thermomechanical models

Francis PW, Hawkesworth CJ (1994) Late Cenozoic rates of magmatic activity in the Central Andes and their relationship to continental crust formation and thickening. J Geol Soc Lon. 151:845-854

Freymuth H, Brandmeier B, Wörner G (InRev.) The source of Central Andean ignimbrite and andesite magmatism characterized by oxygen and strontium isotopes. Submitted to Contrib. Mineral. Petrol

Gardeweg MC, Sparks RSJ (1998) Evolution of Lascar Volcano, northern Chile. J Geol Soc Lond $155: 89-104$

Gardien V, Thompson AB, Grujic D, Ulmer P (1995) Experimental melting of biotite + plagioclase + quartz $\backslash$ muscovite assemblages and implications for crustal melting, J. Geophys. Res. 100: $15581-15591$

Gephart JW (1994) Topography and subduction geometry in the central Andes: clues to the mechanics of a non-collisional orogen. J. Geophys. Res. 99 (B6),12279-12288

Gerya TV (2014) Plume-induced crustal convection: 3D thermomechanical model and implications for the origin of novae and coronae on Venus, Earth Planet. Sci. Lett. 391, 183-192, doi:10.1016/j.eps1.2014.02.005

Giese P (1994) Geothermal structure of the Central Andean crust - implications for heat transport and rheology. Tectonics of the southern Central Andes 69-76

Giese P, Scheuber E, Schilling F, Schmitz M, Wigger P (1999) Crustal thickening processes in the central Andes and the different nature of the Moho discontinuity, J. S. Am. Earth Sci. 12: 201210

Gotberg N, McQuarrie N, Caillaux V (2010) Comparison of crustal thickening budget and shortening estimates in southern Peru (12-14 S): implications for mass balance and rotations in the 'Bolivian orocline', Bull. geol. Soc. Am. 122 (5-6): 727-742

Gualda GAR, Ghiorso MS, Lemons RV, Carley TL (2012) Rhyolite-MELTS: A modified calibration of MELTS optimized for silica-rich, fluid-bearing magmatic systems. J. Petrol. 53:875-890

Hartley AJ, Sempere T, Wörner G (2007) A comment on "Rapid late Miocene rise of the Bolivian Altiplano: Evidence for removal of mantle lithosphere" by C.N. Garzione et al.: Earth Planet Sci Lett. 259: 625-629, doi: 10.1016/j.eps1.2007.04.012

Hildreth W, Moorbath S (1988) Crustal contributions to arc magmatism in theAndes of Central Chile. Contrib. Mineral. Petrol. 98, 455 - 489

Hoefs J (2004) Stable Isotope Geochemistry. Springer-Verlag, Berlin Heidelberg

Hora JM, Singer BS, Wörner G (2007) Volcano evolution and eruptive flux on the thick crust of the Andean Central Volcanic Zone: ${ }^{40} \mathrm{Ar} /{ }^{39} \mathrm{Ar}$ constraints from Volcán Parinacota, Chile. Geol. Soc. Am.a Bull. 119(3-4): 343-362 
Chapter 3 - Temporal changes in mantle wedge geometry and magma generation processes in the Central Andes: Towards linking petrological data to thermomechanical models

Isacks B (1988) Uplift of the Central Andean plateau and bending of the Bolivian orocline. J Geophys Res, Solid Earth and Planets 93:3211-3231

James DE, Sacks IS (1999) Cenozoic formation of the Central Andes: a geophysical perspective. Geology and Ore Deposits of the Central Andes 7: 1- 25

Karátson D, Telbisz T, Wörner G (2011) Erosion rates and erosion patterns of Neogene to Quaternary stratovolcanoes in the Western Cordillera on the Central Andes: An SRTM DM based analysis. Geomorph. 139-140:122-135

Kay SM, Coira BL (2009) Shallowing and steepening subduction zones, continental lithospheric loss, magmatism, and crustal flow under the Central Andean Altiplano- Puna Plateau. Backbone of the Americas: shallow subduction, plateau uplift, and ridge and terrane collision 204 - 229

Kay SM, Coira B, Mpodozis C (1995) Neogene magmatic evolution and the shape of the subducting oceanic slab beneath the central Andean arc. IUGG 21th General Assembly, A440. Boulder, CO: Int. Union Geod. Geophys

Kay SM, Coira B, Viramonte J (1994) Young mafic back arc volcanic rocks as indicators of continental lithospheric delamination beneath the Argentine Puna Plateau, Central Andes: J. Geophys. Res., 99: 24,323-24,339, doi: 10.1029/94JB00896

Kay R, Kay S (1993) Delamination and delamination magmatism: Tectonophysics, 219: 177-189

Kay SM, Maksaev V, Moscoso RC Mpodozis C, Nasi C (1987) Probing the evolving Andean Lithosphere: Mid-Late Tertiary magmatism in Chile $\left(29^{\circ}-30^{\circ} 30^{\prime} \mathrm{S}\right)$ over the modern zone of subhorizontal subduction. J. Geophys. Res. Solid Earth 92: 6173- 6189. doi: 10.1029/JB092iB07p06173

Kay SM, Ramos VA, Dickinson WR (2009) Backbone of the Americas: Shallow subduction, plateau uplift, and ridge and terrane collision: Geol. Soc. Am. Mem. 204 -278

Kay S. M., Coira B. L., Caffe P. J., Chen C.-H. (2010) Regional chemical diversity, crustal and mantle sources and evolution of central Andean Puna plateau ignimbrites. J Volcanol Geoth Res 198:81-111. doi:10.1016/j.jvolgeores.2010.08.013

Kennan L, Lamb SH, Hoke L (1997) High-altitude palaeosurfaces in the Bolivian Andes: Evidence for late Cenozoic surface uplift, in Widdowson, M., ed., Palaeosurfaces: Recognition, reconstruction, and palaeo-environmental interpretation: Geol. Soc. London. Special Publication no. 120:307-323

Kincaid C, Silver P (1996) The role of viscous dissipation in the orogenic process, Earth Planet. Sci. Lett., 142(3-4), 271-288, doi:10.1016/0012-821X(96)00116-1

Kley J, Monaldi CR (1998) Tectonic shortening and crustal thickness in the Central Andes: how good is the correlation? Geol. 26: 723-726 
Chapter 3 - Temporal changes in mantle wedge geometry and magma generation processes in the Central Andes: Towards linking petrological data to thermomechanical models

Koulakov I, Sobolev SV Asch G (2006). P- and S-velocity images of the lithosphere-asthenosphere system in the Central Andes from local-source tomographic inversion, Geophys. J. Int. 167: $106-126$

Lamb S, Davis P (2003) Cenozoic climate change as a possible cause for the rise of the Andes. Nature 425: 792-797

Lamb S, Hoke L (1997) Origin of the high plateau in the Central Andes, Bolivia, South America: Tectonics. 16: 623-649

Lamb S, Hoke L, Kennan L, Dewey J (1997) Cenozoic evolution of the Central Andes in Bolivia and northern Chile, in Burg, J.-P., and Ford, M., eds., Orogeny through time: Geol. Soc. London. Special Publication 121:237-264

Laube N, Springer J (1998) Crustal melting by ponding of mafic magmas: a numerical model, J. Volcanol. Geotherm. Res. 81:19-35

Leloup PH, Ricard Y, Battaglia J, Lacassin R (1999) Shear heating in continental strike-slip shear zones: model and field examples. Geophys. J. Int. 136:19-40

Lloyd S, van der Lee S, Sand F ranca G, Assumpcao M, Feng, M (2010) Moho map of South America from receiver functions and surface waves, J. geophys. Res. 115: B11315, doi:10.1029/2009JB006829

Lucassen F, Becchio R, Harmon R, Kasemann S, Franz G, Trumbull R, Romer RL, Dulski P (2001) Composition and density model of the continental crust in an active continental margin : the Central Andes between $18^{\circ} \mathrm{S}$ and $27^{\circ} \mathrm{S}$, Tectonophysics 341:195-223

Lucassen F, Thirlwall MF (1998) Sm-Nd formation ages and mineral ages in metabasites from the Coastal Cordillera, northern Chile. Geol Rundschau 86:767-774

Mamani M, Tassara A, Wörner G (2008) Composition and structural control of crustal domains in the central Andes. Geochem Geophys Geosyst 9: doi:10.1029/2007GC001925

Mamani M, Wörner G, Sempere T (2010) Geochemical variations in igneous rocks of the Central Andean Orocline. Geol Soc Am Bull 122:162-182

Marshall LG, Sempere T, Gayet M (1993) The Petaca (late Oligocene-middle Miocene) and Yecua (late Miocene) Formations of the Subandean-Chaco basin, Bolivia, and their tectonic significance: Documents des Laboratoires de Géologie, Lyon 125: 291-301

Masek JG, Isacks BL, Gubbels TL, Fielding EJ (1994), Erosion and tectonics at the margins of continental plateaus: J. Geophys. Res. 99: 13941-13956

McCaffrey KJW, Petford N (1997) Are granitic intrusions scale invariant?, J. Geol. Soc. London $154: 1-4$ 
Chapter 3 - Temporal changes in mantle wedge geometry and magma generation processes in the Central Andes: Towards linking petrological data to thermomechanical models

McGlashan N, Brown L, Kay S (2008) Crustal thickness in the central Andes from teleseismically recorded depth phase precursors, Geophys. J. Int. 175: 1013-1022

Mégard F, Noble DC, McKee EH, Bellon H (1984) Multiple pulses of Neogene com- pressive deformation in the Ayacucho intermontane basin, Andes of central Peru: Geol Soc Am Bulletin. 95: $1108-1117$

Molnar P, Garzione CN (2007) Bounds on the vis- cosity coefficient of continental lithosphere from re moval of mantle lithosphere beneath the Altiplano and Eastern Cordillera: Tectonics. 26: TC2013, doi: 10.1029/2006TC001964

Muñoz N, Charrier R (1996) Uplift of the western border of the Altiplano on a west-vergent thrust system, northern Chile: J. S. Am. Earth Sci. 9: 171-181

Myers S, Beck S, Zandt G, Wallace T (1998) Lithospheric-scale structure across the Bolivian Andes from tomographic images of velocity and attenuation for P and S waves, J. Geophys. Res. 103 (21): $233-221,252$

Oncken O, Hindle D, Kley J, Elger K, Victor P, Schemmann K (2006) Deformation of the Central Andean upper plate system-Facts, fiction, and constraints for plateau models, in Oncken, O., et al., eds., The Andes-Active subduction orogeny: Frontiers in Earth Sciences: New York, Springer, 3-27

Pardo-Casas F, Molnar P (1987) Relative motions of the Nazca (Farallon) and South American plates since late Cretaceous time. Tectonics 6: 233-248

Petford N, Cruden AR, McCaffrey KJW, Vigneresse JL (2000) Granite magma formation, transport and emplacement in the Earth's crust, Nature 40:669-673

Pichowiak, S.; Buchelt, M.; Damm, K.W. 1990. Magmatic activity and tectonic setting of early stages of Andean cycle in northern Chile. Geol Soc Am, Special Paper 241: 127-144

Plank T, Langmuir CH (1998) The geochemical composition of subducting sediment and its consequences for the crust and mantle. Chem. Geol. 145: 325-394. doi: 10.1016/S00092541(97)00150-2

Pope DC, Willett SD (1998) Thermo-mechanical model for crustal thickening in the central Andes driven by ablative subduction: Geol. 26: 511-514

Roeder D (1988) Andean-age structure of Eastern Cordillera (Province of La Paz, Bolivia): Tectonics. 7: 23-39

Rogers G, Hawkesworth CJ (1989) Reply to comment of C.R. Stern on "A geochemical traverse across North Chilean Andes: evidence for crust generation from the mantle wedge". Earth Planet. Sci. Lett. $101: 134-137$ 
Chapter 3 - Temporal changes in mantle wedge geometry and magma generation processes in the Central Andes: Towards linking petrological data to thermomechanical models

Rudnick RL, Gao S (2004) Composition of the Continental Crust. In: Treatise on Geochemistry. Holland, H.D. and Turekian, K.K. (Editors), Elsevier, Amsterdam. 3: 1-64

Ruprecht P, Wörner G (2007) Variable regimes in magma systems documented in plagioclase zoning patterns: El Misti stratovolcano and Andagua monogenetic cones (S. Peru). J. Volcan. Geotherm. Res. 165:142-162

Russo RM, Silver PG (1996) Cordillera formation, mantle dynamics, and the Wilson cycle. Geol. 24: $511-514$

Sandeman HA, Clark A H, Farrer E (1995) An Integrated Tectono- Magmatic Model for the Evolution fo the Southern Peruvian Andes $\left(13^{\circ}-20^{\circ} \mathrm{S}\right)$ since $55 \mathrm{Ma}$. Internat Geol Rev. 10391073

Schmitz M (1994) A balanced model of the southern Central Andes: Tectonics. 13: 484-492.

Sempere T, Butler RF, Richards DR, Marshall LG, Sharp W, Swisher CC (1997) Stratigraphy and chronology of Upper Cretaceous-lower Paleogene strata in Bolivia and northwest Argentina: Geol. Soc. Am. Bull. 109: 709-727

Sheffels BM (1995) Mountain building in the Central Andes: An assessment of the contribution of crustal shortening: Internat Geol Rev. 37: 128-153

Silver PG, Russo RM, Lithgow-Bertelloni C (1998) Coupling of South American and African plate motion and plate deformation: Sci. 279: 60-63

Sobolev SV, Babeyko AY, Koulakov I, Oncken O (2006) Mechanism of the Andean orogeny: insight from numerical modeling. In: Oncken O, Chong G, Frank G, Giese P, Götze H.J, Ramos VA, Strecker MR, Wigger P (Eds.), The Andes - active subduction orogeny. Frontiers in Earth Science Series, Springer-Verlag, Berlin. 1:509-531

Somoza R (1998) Updated Nazca (Farallon)-South America relative motions during the last $40 \mathrm{My}$ : implications for the mountain building in the central Andean region: J. S. Am. Earth Sci. 11:211215

Spera FJ, Bohrson WA (2001) Energy-constrained open-system magmatic processes I: general model and energy-constrained assimilation and fractional crystallization (EC-AFC) formulation. J. Petrol. 42: 999-1018

Spera FJ, Bohrson WA (2002) Energy-constrained open-system magmatic processes III: energyconstrained recharge, assimilation and fractional crystallization (EC-RAFC). Geochem. Geophys. Geosys. 3, doi:10.1029/2002GC00315 
Chapter 3 - Temporal changes in mantle wedge geometry and magma generation processes in the Central Andes: Towards linking petrological data to thermomechanical models

Spera FJ, Bohrson WA (2004) Open-system magma chamber evolution: An energy-constrained geochemical model incorporating the effects of concurrent eruption, recharge, variable assimilation and fractional crystallization (EC-E’RAxFC). J. Petrol. 45: 2459-2480

Springer M, Förster A (1998) Heat-flow density across the Central Andean subduction zone, Tectonophysics 291:123-139

Syracuse, E.M., van Keken, P.E., Abers, G.A., 2010. The global range of subduction zone thermal models. Phys. Earth Planet. Inter. 183: 73-90. doi:10.1016/j.pepi.2010.02.004

Taylor SR, McLennan SM (1985) The Continental Crust: Its Composition and Evolution: An examination of the Geochemical Record Preserved in Sedimentary Rocks , 307 , Blackwell Sci., Malden, Mass

Thouret JC, Rivera M, Wörner G, Gerbe MC, Finizola A, Fornari M, Gonzales K (2005) Ubinas: the evolution of the historically most active volcano in southern Peru. Bull. Volcanol. 67: 557 589. doi.org/10.1007/s00445-004-0396-0

Thouret JC, Wörner G, Gunnell Y, Singer B, Zhang X, Souriot T (2007) Geochronologic and stratigraphic constraints on canyon incision and Miocene uplift of the Central Andes in Peru. Earth Planet Sci Lett. 263: 151- 166.

Van der Hammen T, Werner JH, Van Dommelen H (1973) Palynological record of the up- heaval of the Northern Andes: A study of the Pliocene and lower Quaternary of the Colombian Eastern Cordillera and the early evolution of its high-Andean biota: Rev. Palaeobot Palynol. 16: 1-122

Van Keken PE, Hacker BR, Syracuse EM, Abers GA (2011) Subduction factory: 4. Depth-dependent flux of $\mathrm{H}_{2} \mathrm{O}$ from subducting slabs worldwide. J. Geophys. Res. 116. http:/dx.doi.org/10.1029/2010JB007922

Vigneresse JL, BarbeyP, Cuney M (1996) Rheological transitions during partial melting and crystallisation with application to felsic magma segregation and transfer, J. Petrol. 37:15791600

Vroon PZ, Bergen MJV, White WM, Varekamp JC (1993) Sr-Nd-Pb isotope systematics of the Banda Arc, Indonesia: Combined subduction and assimilation of continental material, J. Geophys. Res., 98 , 22,349-22,366

Wada I, Behn MD, Parmentier EM, Shaw AM (2011) Focusing of upward fluid migration due to mineral grain size variation. In: Goldschmidt Conference. Prague, 2011

Watts AB, Lamb SH, Fairhead JD, Dewey JF (1995) Lithospheric flexure and bending of the Central Andes: Earth Planet Sci Lett. 134: 9-21 
Chapter 3 - Temporal changes in mantle wedge geometry and magma generation processes in the Central Andes: Towards linking petrological data to thermomechanical models

Whitman D (1999) The isostatic residual gravity anomaly of the Central Andes, $12^{\circ}$ to $29^{\circ} \mathrm{S}$ : A guide to interpreting crustal structure and deeper lithospheric processes: International Geology Review. 41: 457-475

Whitman D, Isacks BL, Mahlburg S (1996) Lithospheric structure and along-strike segmentation of the Central Andean Plateau: Topography, tectonics, and timing: Tectonophysics, 259: 29-40

Whitman D, Isacks BL, Kay SM (1993) Lithospheric Structure and Along-Strike Segmentation of the Central Andean Plateau, 17-29 ${ }^{\circ}$ S, in Proceedings of the Second ISAG, Oxford (UK), 21-23/9

Wilson, C.R., Spiegelman, M., van Keken, P.E., submitted for publication. TerraFERMA: the transparent finite element rapid model assembler for multiphysics problems in the Earth sciences. Geochem. Geophys. Geosyst

Wörner G, Harmon RS, Davison JD, Moorbath S, Turner TL, McMillan N, Nye C, López-Escobar L. Moreno H, (1988) The Nevados de Payachata volcanic region $18^{\circ} \mathrm{S} / 69^{\circ} \mathrm{W}$, N. Chile. I. Geological, geochemical and isotopic observations: Bull. Volcan. 50: 287-303, doi: 10.1007/ BF01073587.

Wörner G, Moorbath S, Harmon RS (1992), Andean Cenozoic volcanics reflect basement isotopic domains: Geol. 20: 1103-1106, doi: 10.1130/ 0091-7613(1992)020<1103:ACVCRB>2.3. CO2

Wörner G, Moorbath S, Horn S, Entemann J, Harmon RS, Davidson JP, López-Escobar L (1994) Large- and fine-scale geochemical variations along the Andean arc of northern Chile (17.5 - 22 S). In: Reutter KJ, Scheuber E, Wigger PJ (Eds.), Tectonics of the Southern Central Andes. Structure and Evolution of an Active Continental Margin. Springer, Berlin, 77 - 92

Yáñez G, Cembrano J (2004) Role of viscous plate coupling in the Late Tertiary Andean tectonics. J Geophy Res 10(2): 1-21

Yáñez G, Cembrano J, Pardo M, Ranero, C ,Selles D (2002) The Challenger-Juan Fernández-Maipo major tectonic transition of the Nazca-Andean subduction system at $33^{\circ}-34^{\circ} \mathrm{S}$ : Geodynamic evidence and implications, J. South Am. Earth Sci., 15(1):23-28, doi:10.1016/ S08959811(02)00004-4

Yáñez GA, Ranero CR, Huene R, Díaz J (2001) Magnetic anomaly interpretation across the southern central Andes (32-34 S): The role of the Juan Fernández Ridge in the late Tertiary evolution of the margin. J. Geophys. Res. Solid Earth (1978-2012) 106, 6325- 6345

Yuan X, Sobolev SV, Kind R (2002) New data on Moho topography in the Central Andes and their geodynamic implications: Earth Plan. Sci. Lett. 199:389-402

Yuan X, Sobolev SV, Kind R, Oncken O (2000) Subduction and collision processes in the Central Andes constrained by converted seismic phases. Nature 408:958-961

Zandt G, Velasco A, Beck, S (1994) Composition and thickness of the southern Altiplano crust, Bolivia. Geol. 22, 1003-1006. 


\title{
Chapter 4
}

\section{Systematic compositional distinction of lava samples through time and space at the Central Andean Orocline}

\begin{abstract}
I have investigated the potential of combining major elements and multivariate statistics as a method for characterizing groups of magmas based on ages and chemical compositions. The statistical technique, known as cluster analysis using k-means, is used to correlate and integrate information about relations between major and trace elements. Cluster analysis allows us to identify objectively the major common trends in chemical data and thus to reduce the information to a limited number of characteristic parameter combinations. The application of this procedure to major and trace element data sets is a powerful tool for discerning between effects of differences in end-members or source, different degrees of assimilation, contamination, differentiation, magma mixing and fractional crystallization and the underlying basement. I observe that compositions of andesites erupted before and after crustal thickening are significantly different, not only in trace element compositions (which has been reported before) but also in major elements and are correlated to the progression of Andean orogeny. More importantly, clear correlations of major and trace elements to crustal thickening show that the LREE enrichment and HREE depletion with thick crust are actually controlled by the minor elements (phosphorous and titanium).
\end{abstract}

\subsection{Introduction}

The Andean orogenic chain spans the western coast of the South American continent, parallel to a subduction zone where the Nazca plate descends beneath the South American plate. The CVZ (Central Volcanic Zone) is characterized by continental crust that reaches a thickness of approximately $70 \mathrm{~km}$ mostly a result of crustal shortening and lower crustal flow, where the main crustal thickening occurred between 29-15 Ma (Allmendinger et al., 1997; Beck et al., 1996, Yuan et al., 2002, Yuan et al., 2000; Wörner et al., 2000). A second and major episode of surface uplift developed in the Late Miocene (ca. 10 -6 Ma Gazione et al., 2006, 2008; Schildgen et al., 2007; Thouret et al., 2007). Despite the typical arc signature of magmas, significant geochemical variation can be seen due to crustal contributions (Davidson and DeSilva, 1992; Delacour et al., 2007; Mamani et al., 2010; 
Wörner et al., 2000). In particular, lavas younger than $5 \mathrm{Ma}$ from the CVZ have compositional characteristics that indicate a higher degree of crustal contamination compared with similar andesitic magmas in regions where the crust was/is thinner upon eruption (Davidson et al, 1990; Haschke et al., 2002). Trace elements (HREE and $Y$ and high isotopic ratios) reflect different degrees of crustal contamination (Davidson and de Silva, 1992, 1995; Davidson et al., 1991; Kay et al., 1994, 1996; Wörner et al., 1988, 1992, 1994; Mamani et al., 2010). This difference has been linked to the role of garnet as a stable residual phase during magmatic differentiation and/or assimilation processes under high pressure conditions within the deep crust (Haschke, 2002; Haschke et al., 2006; Mamani et al., 2010). The main assimilation of crustal material takes place at high pressures near the MOHO (chapter 1) and is related with melting, assimilation, storage and homogenization (MASH, Hildreth and Moorbath, 1988). Besides, during ascent from the mantle crust boundary magmas are further contaminated with crustal material. Thus, contamination at the crust mantle boundary and assimilation of crustal material give distinctive geochemical and isotopic characteristics.

Aside from the typical arc signature I have shown in chapter 2, a clear distinction can also be made between individual lava flow volumes of Miocene lava shields and Pliocene/Quaternary stratovolcanoes. Flow volumes vary as a consequence of an increase in convergence rates leading to an increase in melt production rates and effusion rates during the Miocene, followed by a decrease in convergence rate during the Pliocene and Quaternary. Furthermore I showed that through magma mixing, the final conditions of the magma evolution are extremely similar for the Miocene and Pliocene/Quaternary lava. The same holds for the major (andesites representing $80 \%$ of the data; 56$66 \% \mathrm{SiO}_{2}$ ) and most trace elements showing very uniform compositions trough time. In chapter $3 \mathrm{I}$ have tested the hypothesis that chemical differences through time are a cause of crustal thickening. Unfortunately existing codes of conventional igneous geochemical models (MELTS and EC-RAxFC) cannot explain yet all variations of andesite compositions, especially trough time. Multivariate statistics may be able to solve these problems.

Multivariate statistics on compositional data reveals systematic differences in major elements and most trace elements with age that have not been previously discussed in literature. These differences in composition can be the result of several factors; differences in end-members or source, different degrees of assimilation, contamination, differentiation, magma mixing and fractional crystallization. Additonally, the underlying basement can influence the composition of the lavas. By using a statistical approach, this study shows differences in the nature of arc andesites erupted in the same crustal segment before (Miocene) and after (Pliocene/Quaternary) crustal thickening and explains what these differences reveal about the processes of crustal evolution in the magmatic arc. 


\subsection{Tectonic setting}

The Central Andes formed in a long lived convergent setting in which, since Jurassic time, several oceanic plates were subducted and resulted in the formation of a magmatic arc which has migrated about $200 \mathrm{~km}$ eastward since $120 \mathrm{Ma}$ (Stern, 2004). However, the tectonic evolution of the Central Andes has been strongly influenced by fluctuations in the plate convergence rate, obliquity, dip, and rollback of the subducting plate (Somoza, 1998). Subduction was for a long time almost parallel or highly oblique to the continental margin. With the abrupt increase in convergence during the Oligocene, the direction of subduction became more perpendicular to the continent. This appears to be coeval to a major plate boundary reorganization in the Pacific basin initiating the break up of the Farallon Plate and formed Cocos and the Nazca Plate.

In addition, understanding the influence of the migration of the Juan Fernández Ridge on volcanic processes is extremely important. The Juan Fernández ridge began to subduct at $25 \mathrm{Ma}$ at the northern portion of the Peru - Chile trench, and since then, the position of the ridge has migrated southward relative to the continental margin. Reconstruction indicates rapid migration of this point along $\sim 1400$ $\mathrm{km}$ of the margin from 20 to $11 \mathrm{Ma}$. Ridge subduction decreases the subduction angle, and has led to considerable increase in the lithospheric thickness (Pardo et al., 2002), marginal erosion, shoreline indentation, and crustal uplift (Fromm et al., 2004). Moreover, the structural and morphological heterogeneities both in the subducting and overriding plates, the geometrical and thermal evolution, and the growing thickness of the continental crust have all played important roles in the evolution of this magmatic arc.

\subsection{Methods}

\subsubsection{Multivariate statistics on compositional data}

To test the compositional differences in both major and trace elements between Miocene and Pliocene/Quaternary lava samples I use a number of multivariate statistic methods including cluster analysis and time series. The used dataset (chemical analyses and ages) is based on the Andes database (http://andes.gzg.geo.uni-goettingen.de). In any case, before starting multivariate statistics all sample data, using the Andean database, must be converted to centered log transformations, which were done in GoDaPack. The transformed data was then transferred into Statistica for further analysis.

Using statistical (K means) cluster analysis, I classified subjects post hoc into four clusters based on major elements. The term cluster analysis includes a number of different classification algorithms to organize data into meaningful structures or clusters. Or in other words cluster analysis aims to identify groups of individuals that are comparable to each other but different from individuals in other groups. This tool thus aims to cluster the data in a way that the degree of association between the two objects is maximal if they belong to the same group. Beforehand it is unknown which samples 
will fall in which cluster and even the numbers of clusters are unknown. Nevertheless, $k$-means clustering in Statistica produces exactly k different clusters of highest possible dissimilarity.

To better constrain whether any compositional distinctions through time can be made, I use time series data, where sequences of observations are showed ordered in time. I use both methods to test whether Miocene and Pliocene/Quaternary lava samples have a distinct compositional signature. The geochemical data set on which the results and discussion is based comprises about 1000 usable lava samples for multivariate statistics. For the first set of analyses, I selected four representative sample types of Miocene age. Mio-50, the most mafic samples ranging from 50-55 wt\% $\mathrm{SiO}_{2}$, Mio-55 are the intermediate andesites with a silica content of 55-60 wt\%, Mio-60 felsic samples with 60-65 wt $\% \mathrm{SiO}_{2}$ and Mio-65, the most felsic lava samples ranging from $65-70 \mathrm{Wt} \% \mathrm{SiO}_{2}$. Four more groups were selected of Pliocene - Quaternary age, Plio-50, Plio-55, Plio-60 and Plio-65 with approximately the same silica content as the Miocene samples for a good comparison. Since only rocks with $<65 \mathrm{wt}$ $\% \mathrm{SiO}_{2}$ are used the effect of plagioclase fractionation is excluded.

\subsubsection{Cluster analysis (statistics) vs traditional graphics}

Cluster analysis is relatively new in earth sciences, however not uncommon (e.g. Degaetano, 1996; Gong and Richman, 1995, Pacheco, 1998; Steinhorst and Williams, 1985) and was first used by Tryon, 1939. In spite of being more traditional the classical TAS diagram was developed later by (MacDonald and Katsura, 1964). One of the main reasons for using the traditional ways over cluster analysis is probably the ease of use. In general, data can be plotted, untransformed, into TAS, spider, Harker or any other diagram and can immediately yield results without much effort. However for any statistical analysis you need a good understanding of statistics and is much more time consuming. So why use any statistcal analysis?

The main problem with $x-y$ plots of untransformed chemical data is that all variables are dependent on one another. For example, major elements all are summed to $100 \%$, and when one element decreases in concentration all other elements will generally increase in concentration. Therefore in simple x-y plots, correlations between two elements might be "false". This does not apply to trace elements in the same way and even more, trace element ratios are independent of this problem and therefore are widely used in geochemistry. For major elements, this problem can be overcome with transformations. One very important effect of using transformation is that all spurious correlations are eliminated. Besides, transformed data also contains information about unexpected correlations. A practical advantage of transforming data it can process the whole dataset at once.

To get back to cluster analysis, an important problem in the application is the decision regarding how many clusters should be derived from the data. Sometimes, it is already known broadly how the data should be parsed, however, usually the exact number of clusters is unknown. On one hand, you want as few clusters as possible to make them easy to understand and interpretable. On the other hand, having many clusters allows you to identify more segments and more subtle differences 
between segments. To indicate the usefulness of cluster analysis on transformed data I compare in this chapter the data to the more traditional plots.

\subsection{Results and Discussion}

\subsubsection{Major elements}

Instead of typical TAS or AFM diagrams, the transformed data are now displayed in a socalled biplot in order to understand the relationship between the major elements. In Fig. 1 the two Principal Components (PC's) were calculated for major elements and are displayed in a compositional biplot explaining $72 \%$ of the total variability. The sample distribution between the two principal components shows a strong distinction between the most mafic samples (on the left side, dark colors) indicated by the $\mathrm{MgO}, \mathrm{Fe}_{\text {tot }}, \mathrm{CaO}$ vectors close to the first principal component and the most felsic samples (right side, light colors) indicated by $\mathrm{K}_{2} \mathrm{O}, \mathrm{Na}_{2} \mathrm{O}$ and $\mathrm{SiO}_{2}$ vectors. On first sight, this might indicate a typical arc signature suggesting differentiation as the main processes without any clear distinction between the Miocene (Mio) and the Pliocene/Quaternary (Plio) samples. However, $\mathrm{P}_{2} \mathrm{O}_{5}$, $\mathrm{TiO}_{2}, \mathrm{MnO}, \mathrm{Al}_{2} \mathrm{O}_{3}$ vectors show no correlation with $\mathrm{MgO}, \mathrm{Fe}_{\text {tot }}, \mathrm{CaO}$ or the $\mathrm{K} 2 \mathrm{O}, \mathrm{Na}_{2} \mathrm{O}$ and $\mathrm{SiO}_{2}$ vectors suggesting other factors than differentiation might play an important role. 


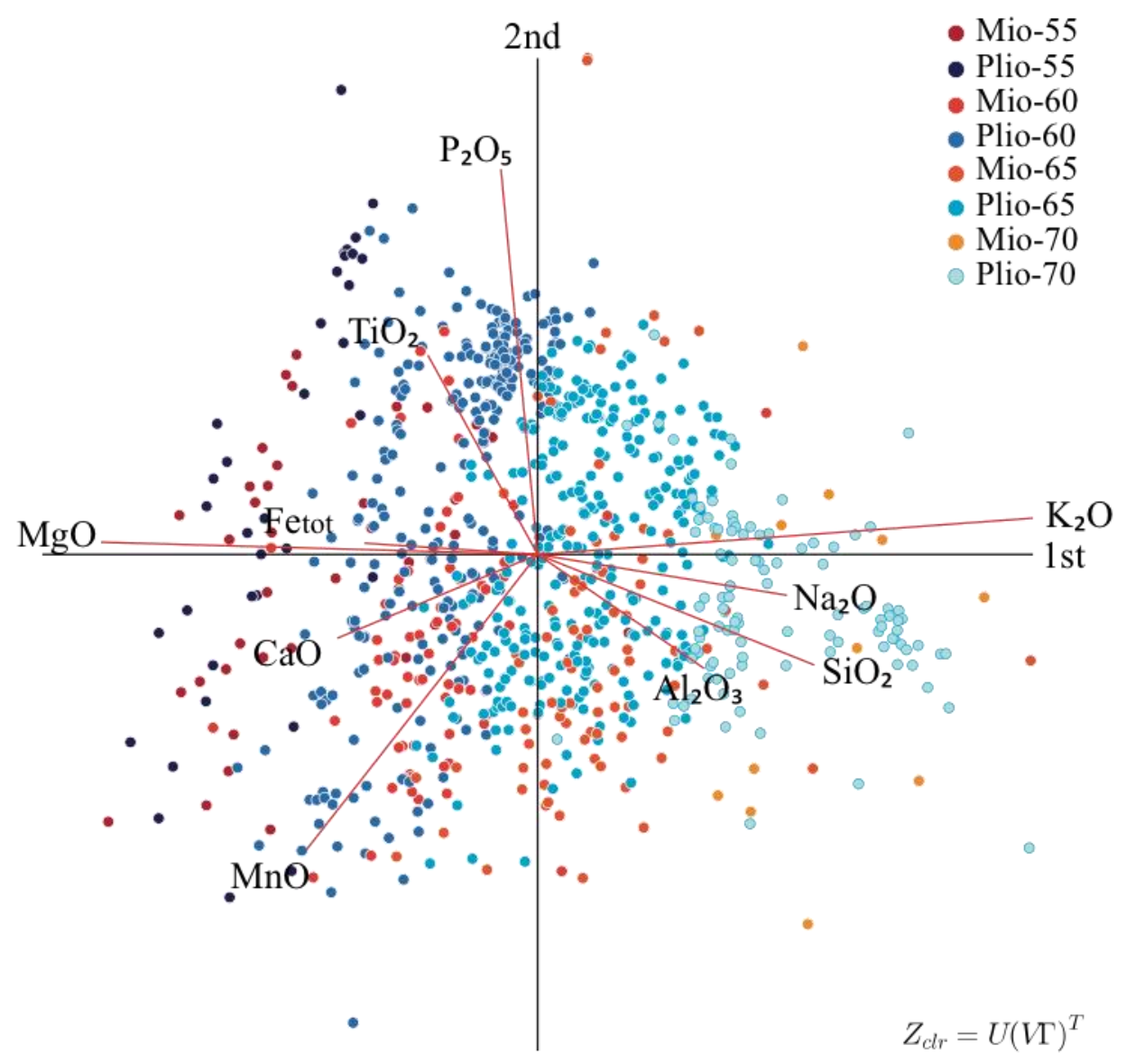

Fig. 1: Compositional biplot ( $1^{\text {st }}$ and $\left.2^{\text {nd }} \mathrm{PC}\right)$ showing clustering results for the major elements

\subsubsection{Cluster analysis on major elements}

The next logical step is to divide all data into clusters rather than predefined groups (e.g. Mio-, Plio). Cluster analysis in Fig. 2 subdivides the samples into four predefined clusters. The reason 4 clusters are chosen is that without any group or cluster the data seems rather arbitrary, being just one set of data without any correlation to be seen. 2 clusters on the other hand will as on the first principal axes (Fig.1) make a distinction between basaltic/andesitic samples and dacitic samples indicating nothing more than differentiation processes. Only when using more than 3 or more clusters other processes are revealed as shown below in figure 2. On the left side first principal component cluster 2 indicating the strongest influence of $\mathrm{MgO}, \mathrm{Fe}_{\text {tot }}, \mathrm{CaO}$ and in lesser extension $\mathrm{MnO}$ with respect to $\mathrm{K}_{2} \mathrm{O}, \mathrm{Na}_{2} \mathrm{O} \mathrm{Al}_{2} \mathrm{O}_{3}$ and $\mathrm{SiO}_{2}$ indicating the most mafic samples. On the opposite side of the first principal component, cluster 4 includes the most felsic samples with the strongest influence of $\mathrm{K}_{2} \mathrm{O}, \mathrm{Na}_{2} \mathrm{O} \mathrm{Al}_{2} \mathrm{O}_{3}$ with respect to $\mathrm{MgO}, \mathrm{Fe}_{\text {tot }}, \mathrm{CaO}$. Clusters 1 and 3 can be subdivided on the second principal component representing samples mostly out of the intermediate or andesitic range. Cluster 3 has the highest abundances from the Plio-60 and Plio-65 group (Table 1) and is strongly influenced by $\mathrm{P}_{2} \mathrm{O}_{5}$ and $\mathrm{TiO}_{2}$ compared to cluster 1. However it is important keep in mind that there might not be an absolute concentration difference concerning the Miocene and Pliocene/Quaternary samples, since the data points are no longer in terms of wt. \% due to clr-transformations. 
As shown in figure 2, statistical cluster analysis of the major elements results reveals two different correlations defined by the two principal components and indicates two different processes: (1) differentiation shown by PC-1 from cluster 2 (most mafic samples) to cluster 4 (most felsic samples). Since $50 \%$ of the analysis can be explained with PC-1 differentiation is therefore the most dominant process. However, some other process must explain the other $50 \%$ of the statistical variability. (2). Both cluster 1 (weak dependence) and 3 (strong dependence) show a major dependency with $\mathrm{P}_{2} \mathrm{O}_{5}$ and $\mathrm{TiO}_{2}$ explaining another $22 \%$ of the chemical variations. Also when comparing $\mathrm{P}_{2} \mathrm{O}_{5}$ cluster results to a $\mathrm{P}_{2} \mathrm{O}_{5}-\mathrm{SiO}_{2}$ Harker diagram the same clear distinction is present between the four clusters (Fig. 5). Cluster 3 is thus enriched and cluster 1 depleted and shows a distinctive elements signature (see also below), strongly suggesting that crustal thickness played a key role in the processes that fractionated the minor elements (Hildreth and Moorbath, 1988). Comparable temporal variations are shown by Haschke et al. (2003). Wörner et al. (1988), Davidson et al. (1991), and McMillan et al. (1993) showed that at $18^{\circ} \mathrm{S}$, arc lavas younger than $7 \mathrm{Ma}$ have unusually high $\mathrm{Sr}$ concentrations, have consistent enrichment levels of barium through titanium and show a depletion in HREEs compared to the older (>7 Ma) magmatic products. These authors took this observation to indicate higher pressure of assimilation in the crust resulting from crustal thickening prior to that time. Further correlation between phosphorous and REE is discussed below. The interaction of mantle derived arc magmas with mature composite crust during different stages of crustal thickening is thus likely indicated by PC-2. Furthermore it is noteworthy that only andesites show the enriched signature and not the mafic and dacitic lavas, this can be due to the fact that these compositions lie close to the end members defined in the Central Andes (Banaszak and Wörner, 2012) and are thus less effected by MASH zone processes (homogenization, assimilation) (Hildreth and Moorbath, 1988).

No significant correlation was found when plotting sample locations the clusters in a digital map (Fig. 3), with the exception of the enriched cluster 3. Figure 3 indicates multiple regions where cluster 3 is more abundant, which is an indication of higher interaction of magma with the lower garnetiferous crust even though the crustal thickness is more or less similar within the whole area. The difference may then also reflect the effect of variable crustal compositions, being more mafic in the enriched regions. 


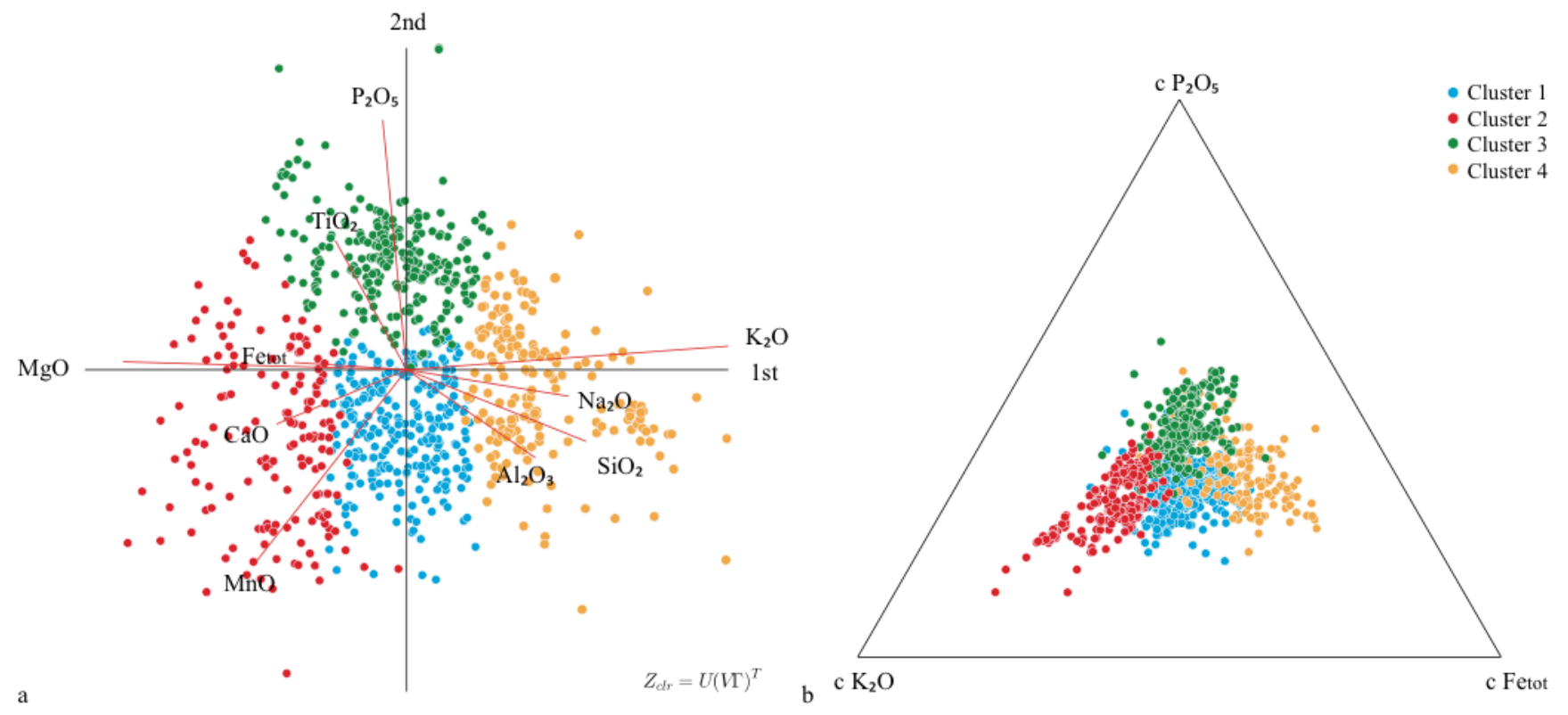

Fig.2: a: Compositional biplot ( $1^{\text {st }}$ and $2^{\text {nd }} \mathrm{PC}$ ) showing the results for 4 different clusters. b: Centered compositions of $\mathrm{P}_{2} \mathrm{O}_{5}$, $\mathrm{K}_{2} \mathrm{O}$ and $\mathrm{Fe}_{\text {tot. }}$ All data are clr-transformed.

Table 1: An overview of the number of used samples from each group and cluster for both Miocene and Pliocene/Quaternary age.

\begin{tabular}{lcccc}
\multirow{5}{*}{ Cluster 1 } & Group & n samples & Group & n samples \\
\cline { 2 - 5 } & Mio-50 & 1 & Plio-50 & - \\
& Mio-55 & 30 & Plio-55 & 52 \\
& Mio-60 & 54 & Plio-60 & 131 \\
& Mio-65 & - & Plio-65 & 1 \\
Cluster 2 & Mio-50 & 30 & Plio-50 & 22 \\
& Mio-55 & 30 & Plio-55 & 68 \\
& Mio-60 & 3 & Plio-60 & 3 \\
Cluster 3 & Mio-65 & - & Plio-65 & - \\
& Mio-50 & 7 & Plio-50 & 14 \\
& Mio-55 & 12 & Plio-55 & 146 \\
& Mio-60 & 11 & Plio-60 & 87 \\
Cluster 4 & Mio-65 & - & Plio-65 & 2 \\
& Mio-50 & 1 & Plio-50 & - \\
& Mio-55 & 1 & Plio-55 & - \\
& Mio-60 & 14 & Plio-60 & 70 \\
& Mio-65 & 12 & Plio-65 & 102 \\
\cline { 2 - 5 } & total & 206 & & 698
\end{tabular}




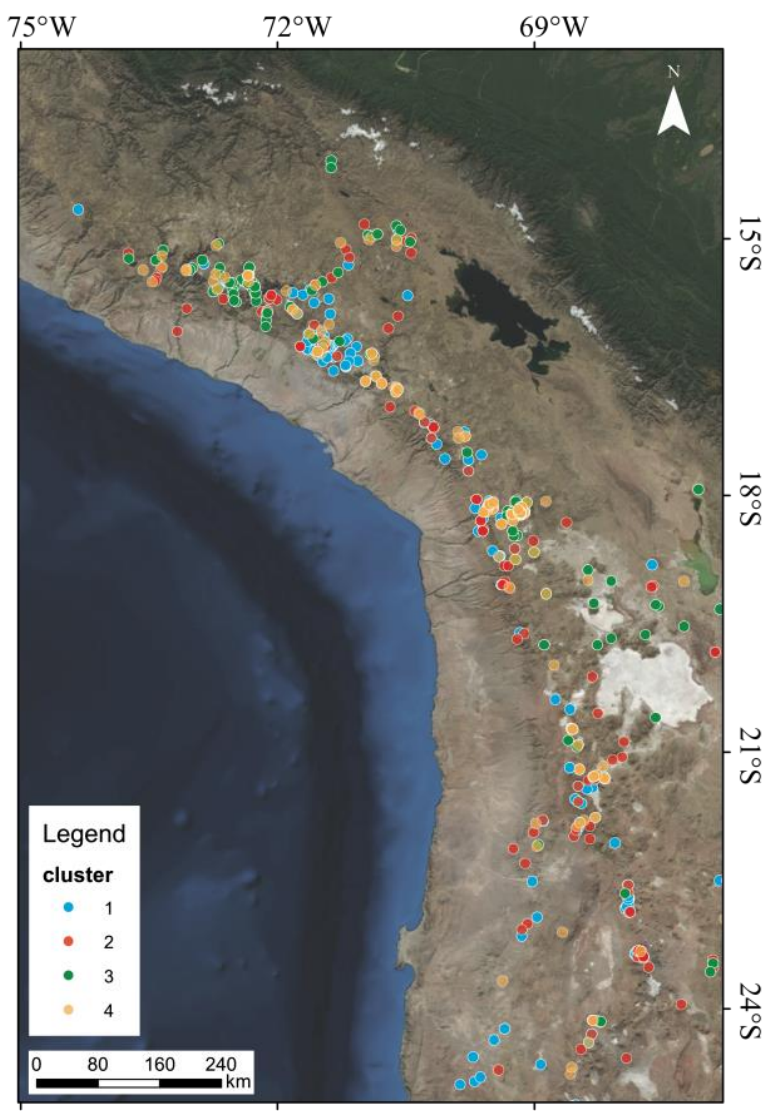

Fig. 3: Cluster 2 (red) is the mafic group and cluster 4 (yellow) the evolved group. Cluster 1 (blue) is depleted and cluster 3 (green) enriched both clusters are of intermediate composition No spatial correlation can be seen for results of cluster analysis, with exception for the enriched cluster 3.

\subsubsection{Cluster analysis or traditional classifications}

Comparing the clr transformation and cluster analysis results to more traditional geochemical classifications, it is clear although not very pronounced, that all four obtained clusters analysis can be distinguished in a TAS diagram (Fig.4) due to the fact that the degree of association between two objects is maximal if they belong to the same group and minimal when otherwise. However without cluster analysis it is impossible to make this distinction. It is apparent from this figure, like figure 2, that differentiation is the most dominant process. Using traditional plots, a distinction can be made between cluster 1 and 3 with higher $\mathrm{Na}_{2} \mathrm{O}$ and $\mathrm{K}_{2} \mathrm{O}$ concentrations in cluster 3 . Or in other words, on average, Pliocene/Quaternary samples should have higher $\mathrm{Na}_{2} \mathrm{O}$ and $\mathrm{K}_{2} \mathrm{O}$ concentrations than Miocene samples.

A major advantage of Harker diagrams (Fig. 5) is that they can be used to identify fractionating phases like olivine, pyroxenes, plagioclase, apatite, magnetite and ilmenite. Harker diagrams show a much broader range in chemical compositions in cluster 3 when compared to cluster 1 however both clusters overlap, except for $\mathrm{P}_{2} \mathrm{O}_{5}$. Phosphorus shows, as in biplot (Fig. 2) a clear distinction between cluster 1 and 3. It should be noted that fractionation processes as indicated by the Harker diagrams give only a simple impression, since most andesites from likely through magma mixing (Chapter 2) making the system much more complex. Thus both clr-transformation results and 
the traditional classifications indicate the same results, however in a biplot all elements and their relation can be shown at once in a more prominent manner.

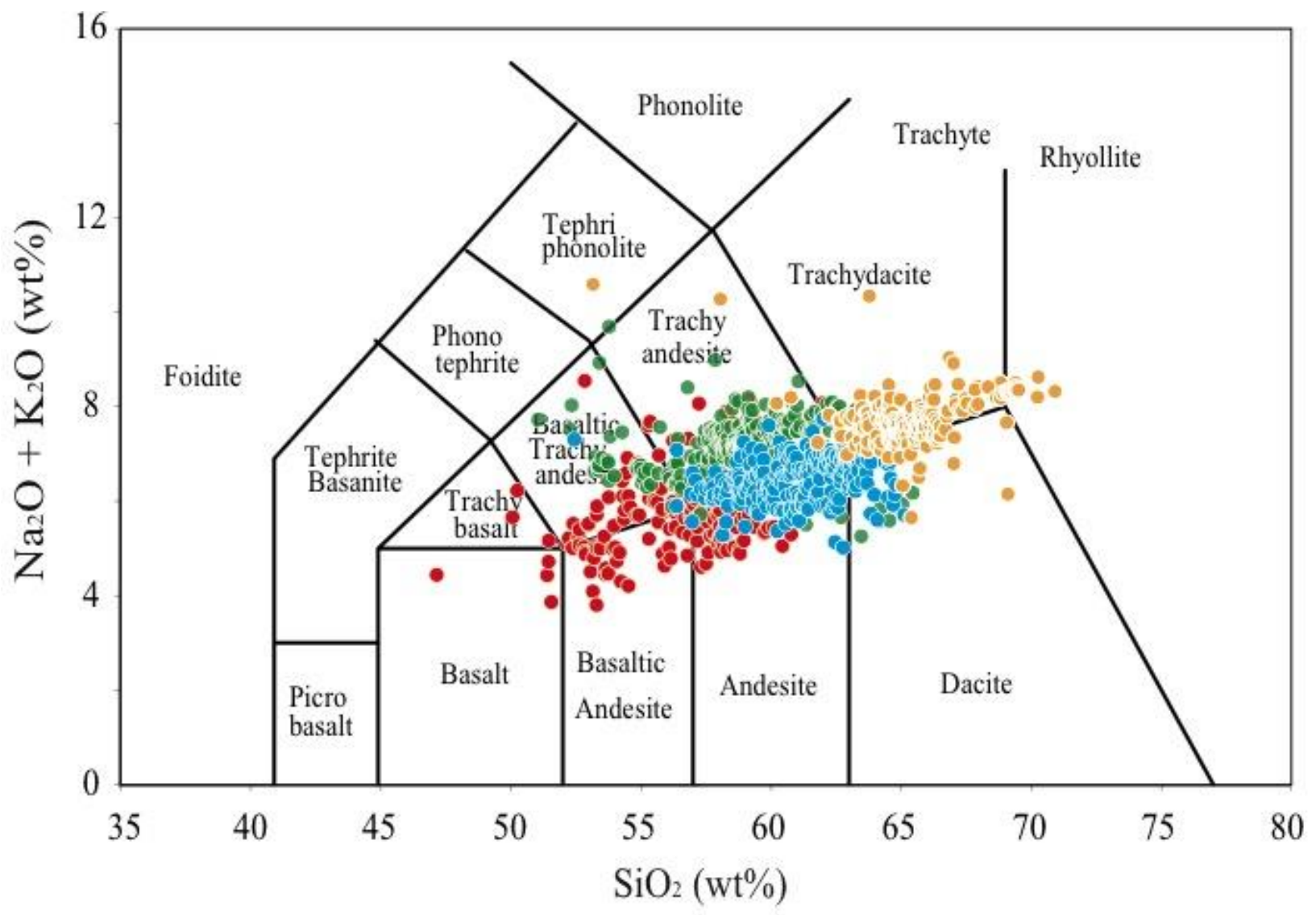

Fig. 4 TAS classification after Le Bas et al., (1986) showing the predominantly andesitic characteristics of the studied lava samples. 

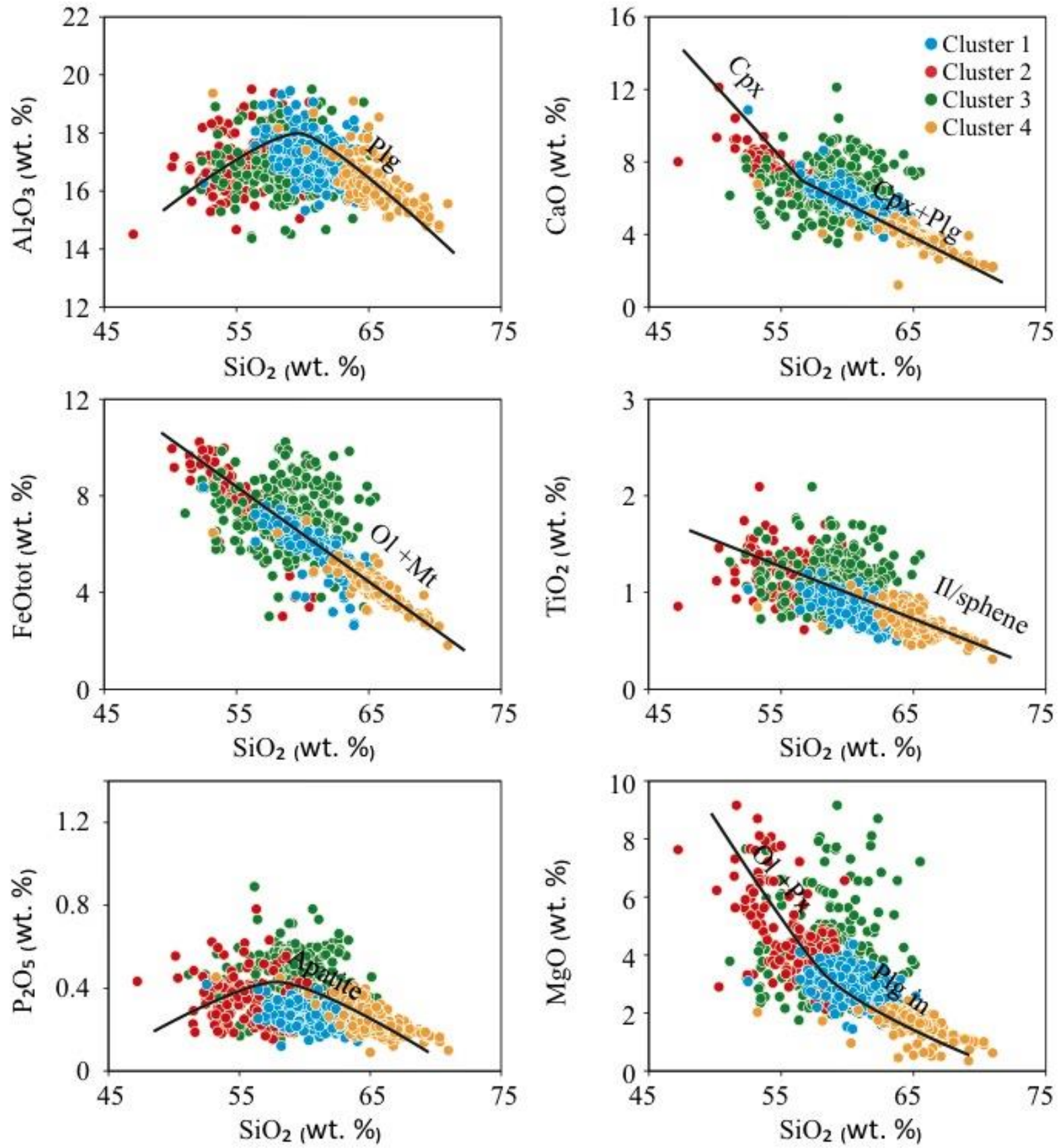

Fig. 5: Harker diagram showing the elemental variations versus $\mathrm{SiO}_{2}$ and indicating the four obtained clusters displaying fractionation trends. $\mathrm{Ol}=\mathrm{Olivine}, \mathrm{Plg}=\mathrm{Plagioclase}, \mathrm{Px}=\mathrm{Pyroxene}, \mathrm{Cpx}=\mathrm{Clinopyroxene}$, Ilmenite, Mt=Magnetite. 


\subsection{4 major elements through time}

To model or identify patterns in time series data ARIMA (Auto Regressive Integrated Moving Average model) was used. Even though patterns of data are often unclear and individual observations involve considerable error, ARIMA allows uncovering hidden patterns. The used dataset contains 182 usable ages from lava samples and were taken from the Andes database. Unfortunately, the time series diagrams show a wide scale jagged transformed chemical data (Fig.6). However, there are general trends visible like the increase in $\mathrm{Na}_{2} \mathrm{O}, \mathrm{K}_{2} \mathrm{O}$ and $\mathrm{P}_{2} \mathrm{O}_{5}$ and decrease in $\mathrm{MgO}, \mathrm{CaO}$ and $\mathrm{MnO}$ with age indicating a differentiation with time. The variations in $\mathrm{Na}_{2} \mathrm{O}, \mathrm{K}_{2} \mathrm{O}, \mathrm{MgO}$ and $\mathrm{CaO}$ can be explained by differentiation and crystal fractionation processes since the younger samples are often higher in silica, however no increase in silica can be seen from the time series diagram neither in $\mathrm{TiO}_{2}, \mathrm{Fe}_{\text {tot }}$ and $\mathrm{Al}_{2} \mathrm{O}_{3}$ and thus the time series data must be treated with care. In spite of the noisy data, $\mathrm{P}_{2} \mathrm{O}_{5}$ seems to increase with time, which is the opposite of expected behavior when differentiation takes place $\left(\mathrm{P}_{2} \mathrm{O}_{5}\right.$ decreases with increasing $\mathrm{SiO}_{2}$ ). Thus as shown by cluster analysis differentiation seems not to control $\mathrm{P}_{2} \mathrm{O}_{5}$. What actually counts is the difference in $\mathrm{P}_{2} \mathrm{O}_{5}$ (and other enriched trace elements) at the same silica content, which is already partially described above and will be elaborated in the next section.

The noisy or jagged pattern is probably due to variation in chemical compositions not related with age. In this plot compositions from basaltic andesites to dacites are plotted, having of course distinct chemical compositions. Therefore it is important not to look in too much detail, but visualize a general pattern with age.

So far I can explain most of the trends within the major elements with differentiation or an enrichment of $\mathrm{P}_{2} \mathrm{O}_{5}$ through time and is the result of an increase of contamination as consequence of crustal thickening. The only element not linked to the four cluster or the 2 principal components is $\mathrm{MnO}$ (Fig.2) however, manganese shows in figure 6 the clearest correlation with age of all elements. Unfortunately, the role of manganese can be attributed to different processes. Manganese is relatively abundant with an average upper crustal abundance of $600 \mathrm{ppm}$ and has a bulk continental crust average of $1400 \mathrm{ppm}$ (McLennan and Taylor, 1996), besides its widely distributed as a minor element in olivine, pyroxene, amphibole and garnet. In theory the decrease of Manganese can thus very well be explained by either differentiation, or more precisely, increase of silicic magmas with age and a thickened crust. However the combination with the time-series data and cluster analysis, this hypothesis is not proven and thus must be treated with care. 

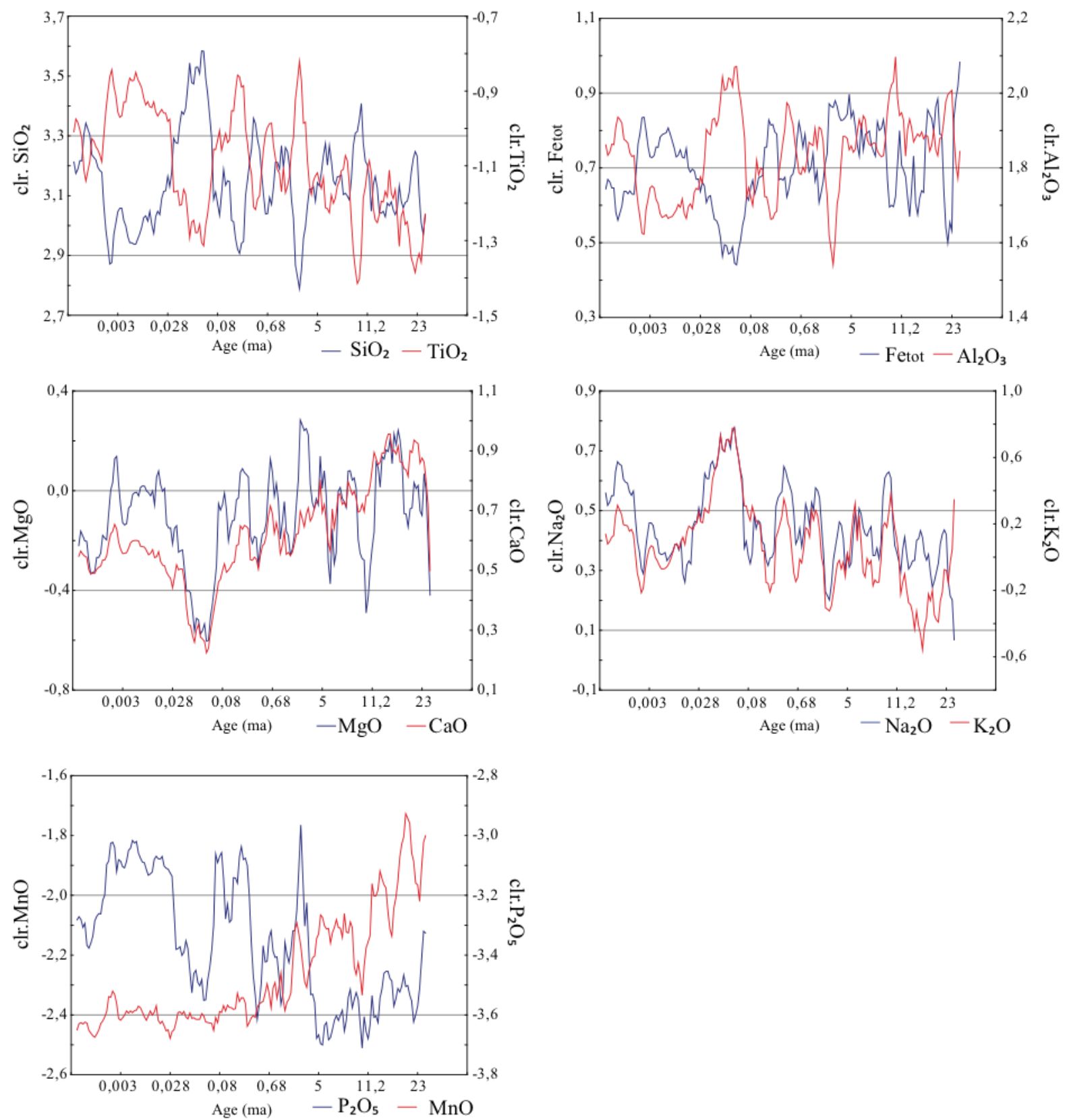

Fig.6: Major element patterns of two series across time showing noisy data, however the general differentiation trend over time reflected by the data is clear. 


\subsubsection{Trace element signatures}

Comparisons between the major and trace elements were made using the previously mentioned cluster analysis on the major elements. The clusters thus remain the same (each data point remains within the same cluster), only here the corresponding trace elements are plotted. A striking result appears when plotting the four clusters obtained by cluster analysis in a trace element biplot (Fig.7a). Within this plot the four clusters can be redivided into three groups can be distinguished responding to LREE, MREE and HREE (1) Ho, Er, Gd and Dy with mostly Pliocene/Quaternary andesitic samples (or cluster 3), (2) Ce, La, Pr, Nd, Sm, Eu or LREE with mostly Pliocene/Quaternary dacitic samples (or cluster 4) and (3) Lu, Yb Tm and Y with Miocene basaltic andesites / andesites and in lesser extent Pliocene/Quaternary basalitic andesites / andesites (a combination of cluster 1 and 2). However, when plotting the four clusters in a trace element ternary diagram ( $\mathrm{Nd}, \mathrm{Ho}, \mathrm{Yb})$ a distinction between cluster 1 and 2 can be made as well (Fig. 7b).

Taken together, these results suggest that there is a strong association between major and trace elements, since no cluster analysis have been performed on the trace elements themselves. In the introduction I already mentioned that lavas younger than $5 \mathrm{Ma}$ from the CVZ have compositional characteristics that indicate a higher degree of crustal contamination (reflected in the HREE and Y trace elements) compared with similar andesitic magmas older than $5 \mathrm{Ma}$ where the crust was thinner upon eruption (Davidson, 1990; Haschke et al., 2002). This increase and high degree of crustal contamination is so far only found in trace elements and minor elements (McMillan et al., 1993; Kay and Mpodozis, 2001; Haschke, 2002; Kay et al., 2005; Haschke et al., 2006; Mamani et al., 2010), however cluster analysis thus shows a correlelation between major, minor and trace elements which has never been reported before.

As for the major elements I can compare the trace element clr-transformed data to more traditional classifications. When plotting all samples of all four clusters in a spiderdiagram a clear separation can be made between the four clusters. LREEs most enriched within cluster 3, the young andesitic group, but also Gd, Dy, Ho and Er are more enriched for cluster 3 and 4 and due to a lack of Miocene dacitic/rhyolitic samples (Table 1) both clusters represent mostly Pliocene/Quaternary lava samples. HREEs, Tm, $\mathrm{Yb}$ and $\mathrm{Lu}$ are on the other hand more depleted in cluster 3 and 4 as in cluster 1 and 2, however this is not the rule for all samples due to a wider range in trace element compositions shown by the reference of cluster 3 .

Mamani et al. (2010) showed very high $\mathrm{Dy} / \mathrm{Yb}$ and $\mathrm{Sm} / \mathrm{Yb}$ ratios for volcanic rocks younger than 3 Ma point to a garnet signature as the only major residual phase controlling REE. The steep gradient for cluster 3 and 4 due to enrichment in LREE and depletion in HREE can exactly be seen in figures 7 and 8 . Figure 9 shows again how well major elements are linked to the trace elements. The steep REE patterns for the younger samples suggest high-pressure source mineralogy. However it must be noted, as shown by table 1, that clusters 3 and 4 are not restricted to only Pliocene/Quaternary samples. 
Despite of many arguments for tectonic thickening of the Andean crust, also (1) subduction of a young oceanic crust and (2) the subduction erosion of forearc crust (Stern, 1990; Kay et al., 2005) can produce the REE signatures or also called adakite signatures. However, (1) the subducting Nazca plate is relatively old and cold, (2) the amount of material that got subducted into the magma source region or was underplated below the fore-arc is a matter of debate (Stern, 1990, 1991; Clift and Hartley, 2007). It is unlikely that significant amounts of sediments have been subducted into the source region due to the Coastal Cordillera acting as a barrier and limits sediment transport into the ocean (Allmendinger et al., 2005). Strong support for REE signatures comes from the positive correlation between the REE and patterns of crustal thickening due to partial melting of granulitic to eclogitic facies continental crust (Hildreth and Moorbath, 1988; Wörner et al., 1988, 1992; Davidson et al., 1990; Trumbull et al., 1999; Mamani et al., 2008, 2010)

However, even within the Pliocene/Quaternary samples, low LREE/HREE can be found even though the modern crust which around $60 \mathrm{~km}$ thick is. In these cases, the lack of a garnet signature can be explained by either variations in the bulk composition of the lower crust that can vary on a rather local scale or crustal contamination at shallower levels (above the stability limit of garnet; ca $30 \mathrm{~km}$ ). Another option might be that the equilibration of melts with crustal garnet may be relatively slow given its sluggish diffusion and that magma ascent rate as discussed in chapter 2 (higher during Miocene times) might be as important as the abundance of garnet in the lower crust. However, it cannot be taken away that volcanoes on thick crust are enriched in LREE (Hildreth and Moorbath, 1988). Even when the garnet is stable in the lower crust, the influence on andesite composition will depend on the abundance of garnet and the degree of equilibration with arc magmas.

In summary, the cluster analysis of four groups based on major elements shows dependence of trace elements on major elements. The strongest chemical signatures displayed by the major elements ( $\mathrm{MgO}, \mathrm{CaO}$, Fetot, $\mathrm{K}_{2} \mathrm{O}, \mathrm{Na}_{2} \mathrm{O}, \mathrm{SiO}_{2}$ and $\mathrm{Al}_{2} \mathrm{O}_{3}$ ) can be explained by differentiation. Secondly, crustal thickening or higher-pressure mineralogy seems to control $\mathrm{P}_{2} \mathrm{O}_{4}$ and $\mathrm{TiO}_{2}$ shown by cluster 3. The dependency of those two elements of crustal thickening can be proven when plotting trace elements as clusters. Cluster 3 shows indeed the steepest REE signature (enriched in LREE and depleted in HREE), which is typical for a thickened crust (Hildreth and Moorbath, 1988, Kay et al., 1991; Mamani et al., 2010). 

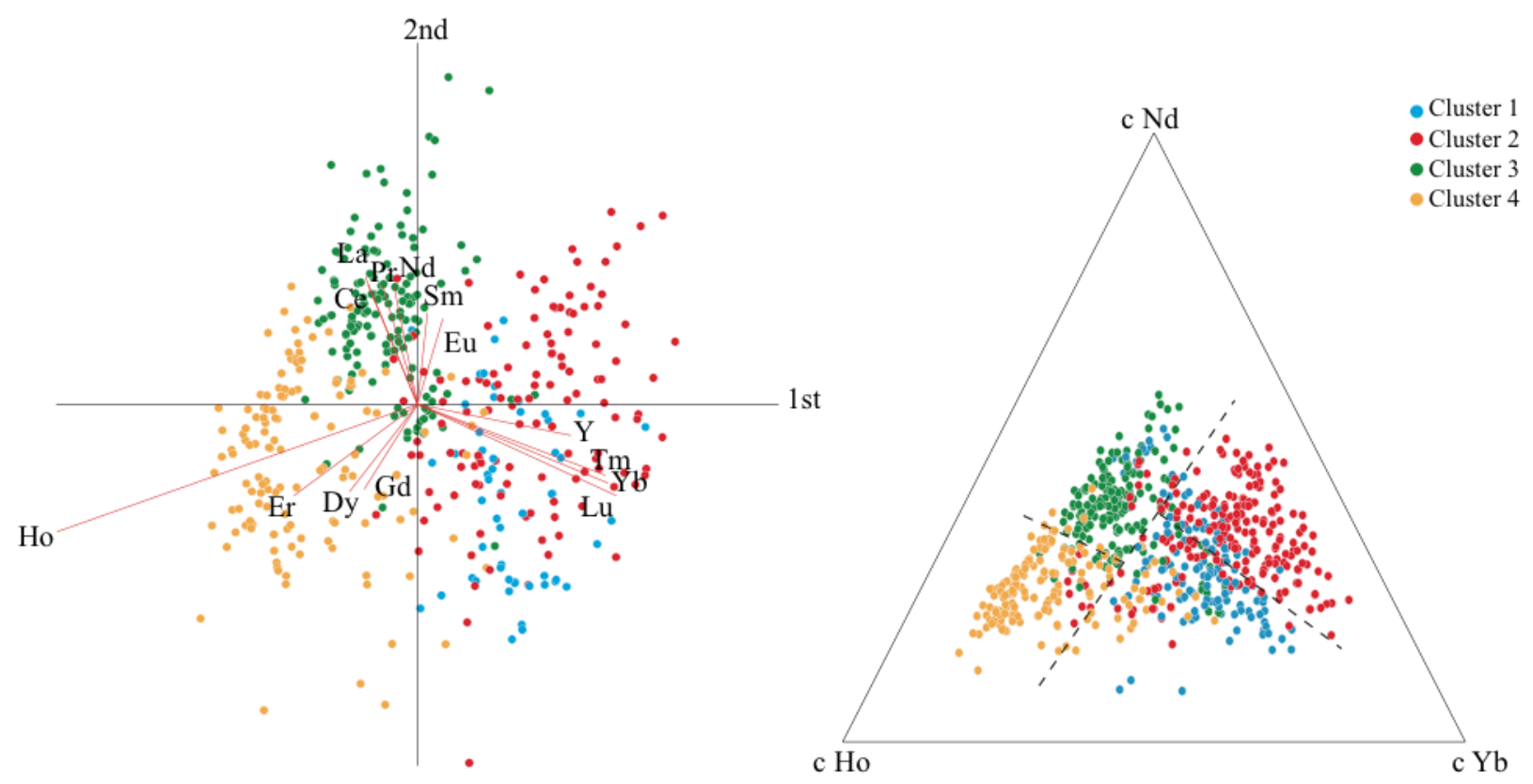

Fig.7 (a) compositional biplot for trace elements with clustering data of major elements. (b) centered ternary plot showing the highest variability between the four clusters. 

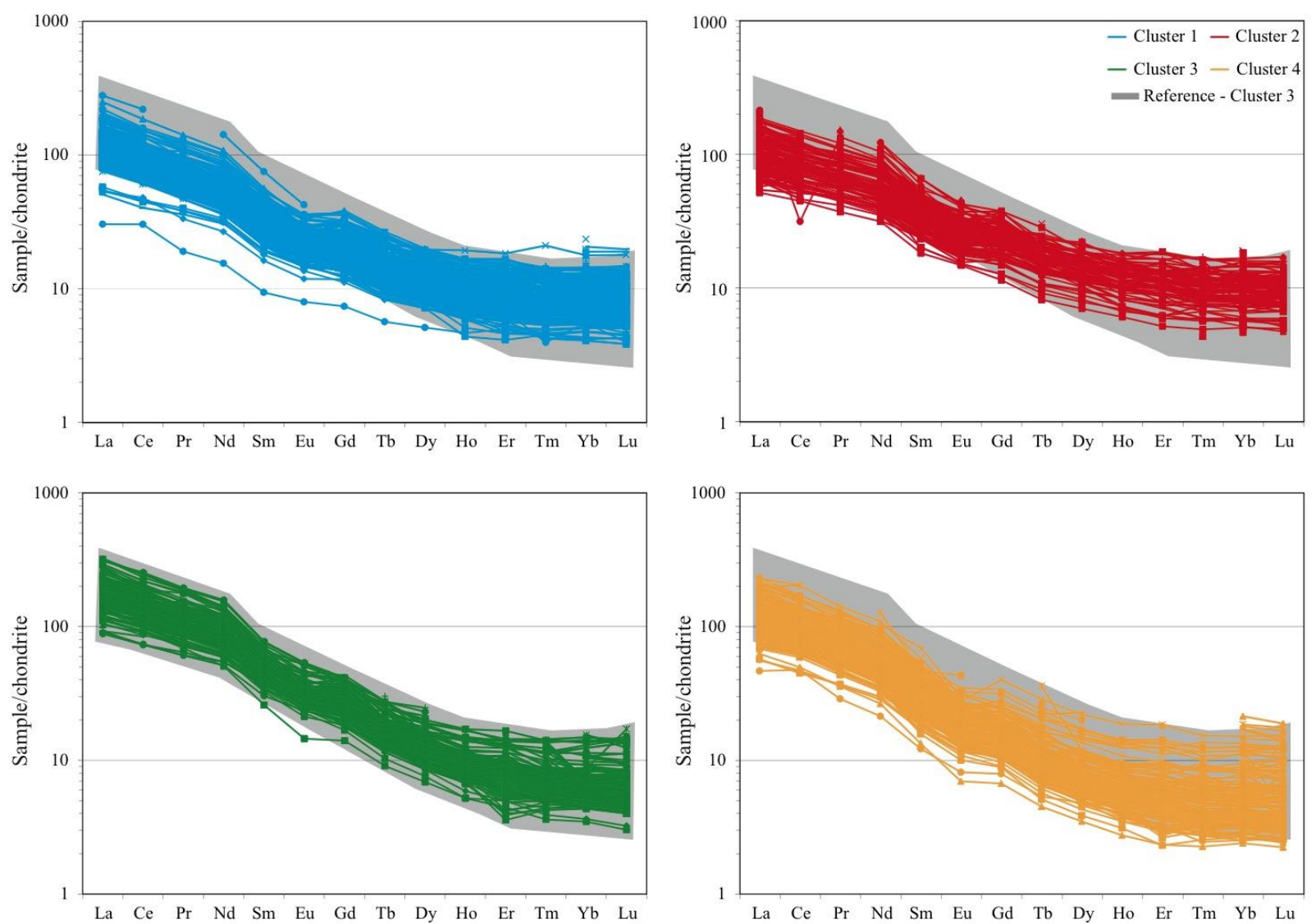

Fig. 8: Chondrite normalized (McDonough and Sun, 1995) REE pattern of the four obtained clusters. Cluster 3 is used as a reference sample for easy comparison.

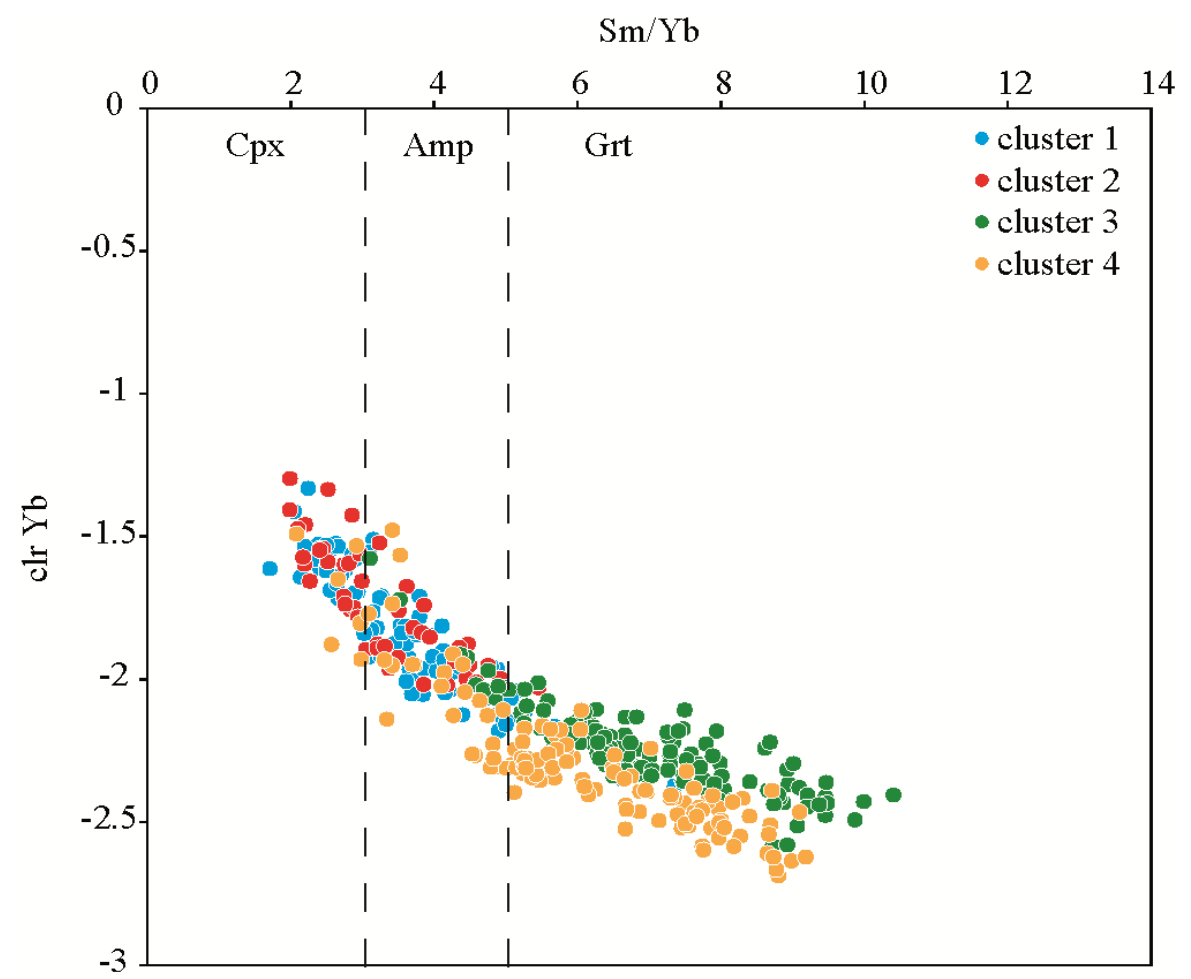

Fig. 9: Plot of $\mathrm{Sm} / \mathrm{Yb}$ vs clr transformed $\mathrm{Yb}$ for four clusters. The plot illustrates the steep REE signature with increasing pressure crystallization. This increase correlates well with the thickening of the Andean crust. 


\subsubsection{Trace elements through time}

In comparison with major elements, the trace elements signature over time is less noisy. Clear trends are visible showing an overall increase of all LREE: La, Ce, Pr, Nd, Sm and Eu (Fig. 10) and a decrease of the HREE: Dy, Ho, Er Tm, Yb and Lu (Fig.10). Again, it is important keep in mind that the data points are no longer in terms of wt. \% due to clr-transformations. Another important observation that can be made is that the LREEs and HREEs these seem to be anti-correlated. The junction of an increase or decrease lies exactly within the MREE or Gd and Tb. Surprisingly, no variations can be seen in $\mathrm{Sr}$ or $\mathrm{Rb}$ which has been identified before and explained by an increase of crustal thickness which started $\sim 25 \mathrm{Ma}$ (Mamani et al., 2008, 2010). As mentioned before constraints on the timing of crustal thickening (and amount) and on the source region can be seen from the temporally changing REE signatures of magmatic arc. However it should not be concluded, since it does not necessary mean that the magma displays changing REE signatures formed before, during and after crustal thickening. My data and data by Mamani et al. (2010) and Kay et al. (2005), show many types of lava without any high-pressure signature even in a thick crustal setting and indicate that the corresponding magmas did not interact significantly with lower crustal lithologies. Most important here is that the timing of crustal thickening can be seen from the maximum values of the REE, possibly reflecting different degrees of crustal contamination (Mamani et al., 2010), however all data used for time series are combined, therefore maximum values are not shown in the same way. The general increase in LREE and decrease of HREE (with decreasing ages) has also been reported by Thorpe, 1979; Kay et al., 1991, 1994, 1999; Hawkesworth, 1988; Haschke et al., 2002, 2003; Mamani et al., 2010 indicating the strong role of crustal thickening fractionating HREE from LREE. However, a heretofore unmentioned point is that the Central Andes is not a single entity and that the timing of uplift and thickening most likely varied from north to south and east to west and can cause distorted variations in an age vs y diagram. 

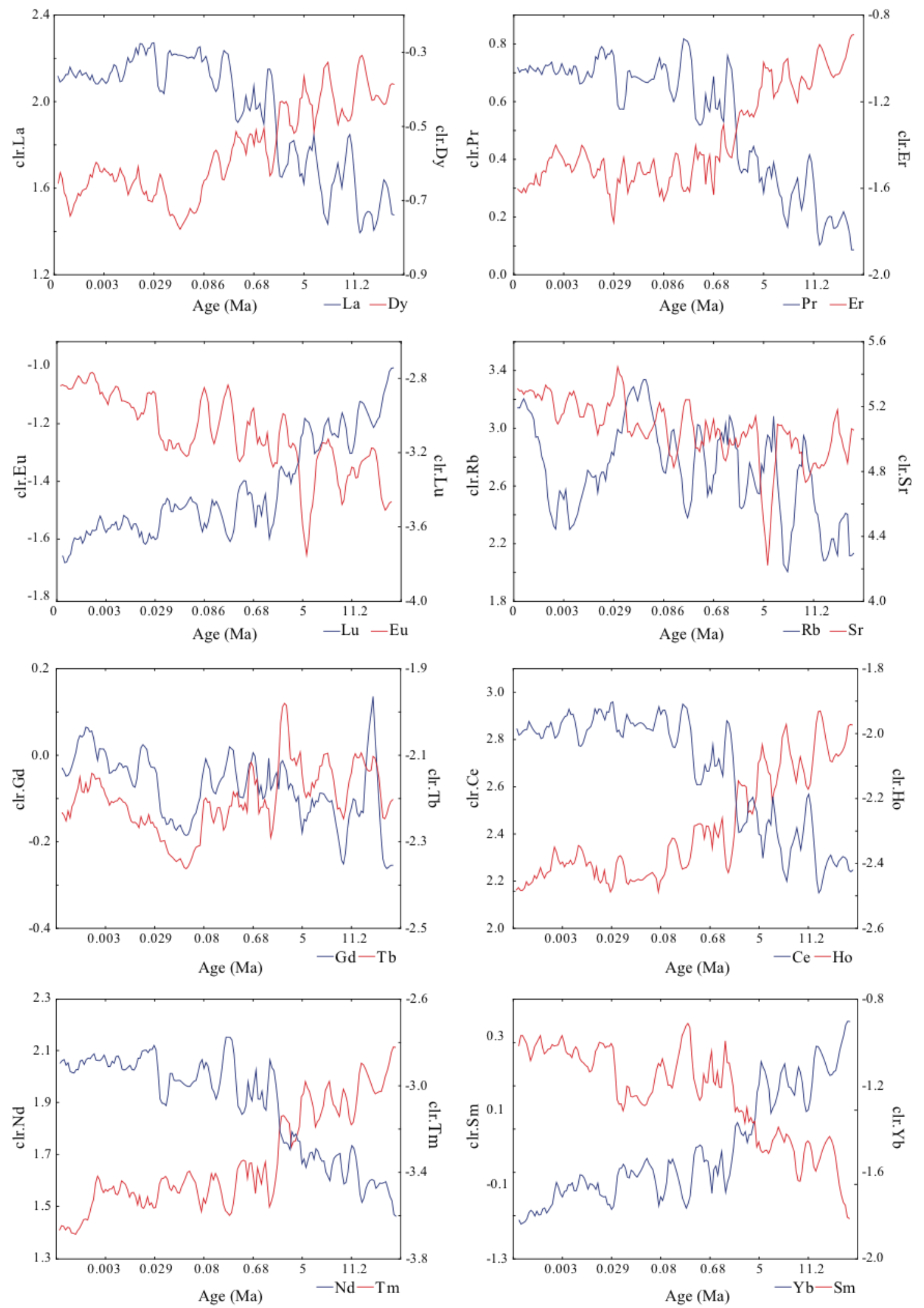

Fig. 10: LREE, HREE, MREE, Rb and Sr patterns of two series across time. Examination shows a general increase of LREE and decrease of HREE through time. 


\subsection{Conclusions}

This chapter has given an account of reasons for the widespread use of multivariate statistics. I have used cluster analysis on clr-transformed of major and trace element data to group andesites according to their geochemical characteristics and compared our results to traditional classifications. This investigation has shown that unexpected correlations in one single geochemical datasets can be found and is statistical correct compared to the traditional classification diagrams. However, one should always use the combination of both methods, as a comparison and traditional classification diagrams still give a lot of additional information, as for example, about fractional crystallization.

The results of this research support the idea that Early Miocene to Quaternary volcanic centers in the main arc reveal systematic differences in trace elements and isotope ratios with age that reflect different degrees of crustal contamination, shown in the biplots and comparison of four found distinctive clusters. However, one of the more significant finding to emerge from this study is that crustal thickening and contamination has a control on the major and minor elements, especially phosphorous and lesser amount titanium, which is then again displayed in trace element signatures.

\section{References Cited}

Allmendinger RW, Jordan TE, Kay SM, Isacks BL (1997) The Evolution of the Altiplano- Puna Plateau of the Central Andes. Annu. Rev. Earth Planet. Sci. 27: 139- 174

Allmendinger RW, González G, Yu J, Hoke G, Isacks B (2005) Trench-parallel shortening in the northern Chilean forearc: Tectonic and climatic implications: Geol. Soc. Am. Bull. 117: 89-104, doi: 10.1130/B25505.1

Banaszak M, Wörner, G (2012) Endmember magma compositions in the Central Andean Volcanic Zone obtained from Polytopic Vector Analysis, Abstract T21E-2620 presented at 2012 Fall Meeting, AGU, San Francisco, Calif., 3-7 Dec

Beck SL, Zandt G, Myers SC, Wallace TC, Silver PG, Drake L (1996) Crustal- thickness variations in the Central Andes. Geol 24: 407- 410

Brunet F, Chazot, G (2001) Partitioning of phosphorus between olivine, clinopyroxene and silicate glass in a spinel lherzolite xenolith from Yemen. Chem. Geol. 176: 51-72

Clift D, Hartley AJ (2007) Slow rates of subduction erosion and coastal underplating along the Andean margin of Chile and Peru: Geol 35: 503-506, doi: 10.1130/G23584A.1 
Colombo F, Sfragulla J, Gonzáles del Tánago J (2012) The garnet-phosphate buffer in peraluminous granitic magmas: a case study from pegmatites of the Pocho District, Córdoba, Argentina. Can. Mineral. 50: 1555-1571

Davidson JP, de Silva SL (1995) Late Cenozoic magmatism of the Bolivian Altiplano. Contrib. Mineral. Petrol. 119: 387 - 408

Davidson JP, De Silva SL (1992) Volcanic rocks from the Bolivian Altiplano: Insights into crustal structure, contamination, and magma genesis in the central Andes. Geol. 20: 1127- 1130

Davidson J, Harmon RSH, Wörner G (1991) The source of Central Andean magmas; some considerations. In: Harmon, Rapela (Eds.), Andean Magmatism and its Tectonic Setting, Geol. Soc. Am. Special Publication. 265: 233 - 243

Davidson JP, De Silva SL, Escobar A, Feeley T, Bohrson W (1990) Evaluation of magma sources for Central Andean volcanics. In: Chil. Geol. Congress Abstracts

Degaetano AT (1996) Delineation of mesoscale climate zones in the northeastern United States using a novel approach to cluster analysis. J. Clim. 9 (8): 1765-1782

Delacour A, Gerbe MC, Thouret JC, Wörner G, Paquereau- Lebti P (2007) Magma evolution of Quaternary minor volcanic centres in Southern Peru, Central Andes. Bull. Volcano. 69: 581608

Fromm R, Zandt G, Beck SL (2004) Crustal thickness beneath the Andes and Sierras Pampeanas at $30^{\circ} \mathrm{S}$ inferred from Pn apparent phase velocities, Geophys. Res. Lett., 31: L06625, doi:10.1029/2003GL019231

Gill J (1981) Orogenic andesites and plate tectonics: Springer Verlag, Berlin, 330

Gong X, Richman MB (1995) On the application of cluster analysis to growing season precipitation data in North America east of the Rockies. J. Clim. 8: 897-931

Haggerty SE, Fung AT, Burt DM (1994) Apatite, phosphorus and titanium in eclogitic garnet from upper mantle. Geophys. Res. Lett. 21: 1699-1702

Haschke M, Günther A (2003) Balancing crustal thickening in arcs by tectonic vs. magmatic means: Geol. 31: 933-936

Haschke MR, Siebel W, Günther A, Scheuber E (2002) Repeated crustal thickening and recycling during the Andean orogeny in north Chile $\left(21^{\circ}-26^{\circ} \mathrm{S}\right)$ : J. Geophys. Res. 107: 1-18, doi: 10.1029/2001JB000328

Haschke M, Günther A, Melnick D, Echtler H, Reutter KJ, Scheuber E, Oncken O (2006) Central and Southern Andean tectonic evolution inferred from arc magmatism. In: Oncken, O., Chong, G., Franz, G., Giese, P., Götze, H.-J., Ramos, V.A., Strecker, M.R., Wigger, P. (Eds.), The Andes Active Subduction Orogeny. Front. Earth Sci. 1:337 - 353 
Hawkesworth CJ, Kemption PD, Rogers NW (1988) Continental mantle lithosphere. Chem. Geol. 70:51-51

Hildreth W, Moorbath S (1988) Crustal contributions to arc magmatism in theAndes of Central Chile. Contrib. Mineral. Petrol. 98, 455 - 489

Hildreth W, Moorbath S (1988) Crustal contributions to arc magmatism in the Andes of central Chile: Contrib. Mineral. Petrol. 98: 455-489, doi: 10.1007/BF00372365

Kay SM, Mpodozis C (2001) Central Andean ore deposits linked to evolving shallow subduction systems and thickening crust. GSA Today 11 (3), 4 - 9

Kay SM, Coira B, Viramonte J (1994) Young mafic back arc volcanic rocks as indicators of continental lithospheric delamination beneath the Argentine Puna Plateau, Central Andes: J. Geophys. Res. 99: 24,323-24,339, doi: 10.1029/94JB00896

Kay SM, Mpodozis C, Coira B (1996) Central Andean mantle-derived basalts and Neogene mantle enrichment beneath the Puna plateau. In: III International Symposium on Andean Geodynamics, Extended Abstract, Saint Malo, France, 583 - 586

Kay SM, Mpodozis C, Coira B (1999) Neogene magmatism, tectonism and mineral deposits of the Central Andes ( $22^{\circ}$ to $33^{\circ} \mathrm{S}$ latitude), in Skinner, B.J., ed., Geology and Ore Deposits of the Central Andes: Soc. Econom Geol. Special Publication 7: 27-59

Kay SM, Godoy E, Kurtz A (2005) Episodic arc migration, crustal thickening, subduction erosion, and magmatism in the south-central Andes: Geol. Soc. Am. 117: 67-88

Konzett J, Frost DJ (2009) The high P-T stability of hydroxyl-apatite in natural and simplified MORB - an experimental study to $15 \mathrm{GPa}$ with implications for transport and storage of phosphorus and Halogens in Subduction zones. J. Petrol. 50 (11): 2043 - 2062

Le Bas MJ, Le Maitre RW, Streckeisen A, Zanettin B (1986). A chemical classification of volcanic rocks on the total alkali_silica diagram. J Petr 27:745-750

Macdonald GA, Katsura T (1964) Chemical composition of Hawaiian lavas, J. Petrol. 5: 82-133, doi:10.1093/petrology/5.1.82

McMillan N, Davidson J, Wörner G, Harmon RS, López-Escober L, Moorbath S (1993) Mecha- nism of trace element enrichment related to crustal thickening: The Nevados de Payachata region, Northern Chile: Geol. 21: 467-470, doi: 10.1130/ 00917613(1993)021<0467:IOCTOA>2.3.CO;2

Mamani M, Tassara A, Wörner G (2008) Composition and structural control of crustal domains in the Central Andes: Geochemistry, Geophysics, Geosystems, 9, doi: 10.1029/2007GC001925 
Mamani M, Wörner G, Sempere T (2010) Geochemical variations in igneous rocks of the Central Andean orocline (13 S to $18 \mathrm{~S}$ ): Tracing crustal thickening and magma generation through time and space. Geol. Soc. Am. Bull. 122: 162- 182

McDonough WF, Sun SS (1995) The composition of the Earth: Chem. Geol. 120: 223-253.

McLennan SM, Taylor SR (1996) Heat flow and the chemical composition of continental crust: The J. Geol. 104: 369-377, doi:10.1086/629834

Pacheco FAL (1998) Finding the number of natural clusters in groundwater data sets using the concept of equivalence class. Comput. Geosci. 14 (1), 7-15

Pardo M, Comte D, Monfret T (2002) Seismotectonic and stress distribution in the central Chile subduction zone. J. S Am. Earth Sci. 15: 11-22

Schildgen TF, Hodges KV, Whipple KK, Reiners PW, Pringle MS (2007) Uplift of the western margin of the Andean plateau revealed from canyon incision history, Southern Peru. Geol. 35, 523- 526

Somoza R (1998) Updated Nazca (Farallon)-South America relative motions during the last 40 My: Implications for the mountain building in the Central Andean region: J. S Am. Earth Sci. 11: 211-215, doi: 10.1016/S0895-9811(98)00012-1

Steinhorst RK, Williams RE (1985) Discrimination of ground water sources using cluster analysis, MANOVA and discriminant analysis. Water Resour. Res. 21 (8), 1149- 1156

Stern CR (1990) Comment on "A geochemical traverse across the North Chilean Andes: Evidence for crust generation from the mantle wedge" by G. Rogers and C.J. Hawkesworth: Earth Planet. Sci. Lett. 101:129-133, doi: 10.1016/0012-821X(90)90134-J

Stern CR (1991) Role of subduction erosion in the generation of Andean magmas: Geol. 19: 78-81, doi: 10.1130/0091-7613

Stern CR (2004) Active Andean volcanism: Its geologic and tectonic setting. Rev. Geol. Chile 31 (2), $161-206$

Thorpe R, Francis P (1979) Variations in Andean andesite compositions and their petrogenetic significance: Tectonophysics, 57: 57-70.

Thompson RN (1975) Is upper mantle phosphorus contained in sodic garnet? Earth Planet. Sci. Lett. $26: 417-424$.

Thouret JC, Wörner G, Gunnell Y, Singer B, Zhang X, Souriot T (2007) Geochronologic and stratigraphic constraints on canyon incision and Miocene uplift of the Central Andes in Peru: Earth Planet. Science Lett. doi: 10.1016/j.epsl.2007.07.023

Trumbull RB, Wittenbrink R, Hahne K, Emmermann R, Büsch W, Gerstenberger H, Siebel W (1999) Evidence for late Miocene to Recent contamination of arc andesites by crustal melts in the 
Chilean Andes $\left(25^{\circ}-26^{\circ}\right.$ S) and its geodynamic implications: J. S Am. Earth Sci. 12: 135-155, doi: 10.1016/S0895-9811(99)00011-5

Wörner G, Harmon RS, Davison JD, Moorbath S, Turner TL, McMillan N, Nye C, López-Escobar L. Moreno H, (1988) The Nevados de Payachata volcanic region $18^{\circ} \mathrm{S} / 69^{\circ} \mathrm{W}$, N. Chile. I. Geological, geochemical and isotopic observations: Bull. Volcanol. 50: 287-303, doi: 10.1007/ BF01073587

Wörner G, Moorbath S, Harmon RS (1992), Andean Cenozoic volcanics refl ect basement isotopic domains: Geol, 20: 1103-1106, doi: 10.1130/ 0091-7613(1992)020<1103:ACVCRB>2.3.CO;2

Wörner G, Moorbath S, Horn S, Entemann J, Harmon RS, Davidson JP, López-Escobar L (1994) Large- and fine-scale geochemical variations along the Andean arc of northern Chile $(17.5-22$ S). In: Reutter KJ, Scheuber E, Wigger PJ (Eds.), Tectonics of the Southern Central Andes. Structure and Evolution of an Active Continental Margin. Springer, Berlin, 77 - 92

Wörner G, Hammerschmidt K, Henjes-Kunst F, Lezaun J, Wilke H (2000) Geochronology (40Ar39Ar-, K-Ar-, and He-exposure-) ages of Cenozoic magmatic rocks from northern Chile $\left(18^{\circ}-\right.$ $\left.22^{\circ} \mathrm{S}\right)$. Implications for magmatism and tectonic evolution of the Central Andes: Revista Geologica Chile 27:205-240

Yáñez G, Cembrano J, Pardo M, Ranero, C Selles D (2002) The Challenger-Juan Fernández-Maipo major tectonic transition of the Nazca-Andean subduction system at $33^{\circ}-34^{\circ} \mathrm{S}$ : Geodynamic evidence and implications, J. South Am. Earth Sci. 15(1):23-28, doi:10.1016/ S08959811(02)00004-4

Yuan X, Sobolev S, Kind R (2002) Moho topography in the central Andes and its geodynamic implications. Earth and Planetary Science Letters 199: 389- 402

Yuan X, Sobolev S, Kind R, Oncken O, Bock G, Asch G, Schurr B, Graeber F, Rudloff A, Hanka W, (2000) Subduction and collision processes in the Central Andes constrained by converted seismic phases. Nature 408: 958- 961 